Jeremy Guy Hicks

Mikhail Zoshchenko and the Poetics of Skaz

PhD Thesis

The University of London

(School of Slavonic and East European Studies)

December 1999 
ProQuest Number: U122782

All rights reserved

INFORMATION TO ALL USERS

The quality of this reproduction is dependent upon the quality of the copy submitted.

In the unlikely event that the author did not send a complete manuscript and there are missing pages, these will be noted. Also, if material had to be removed, a note will indicate the deletion.

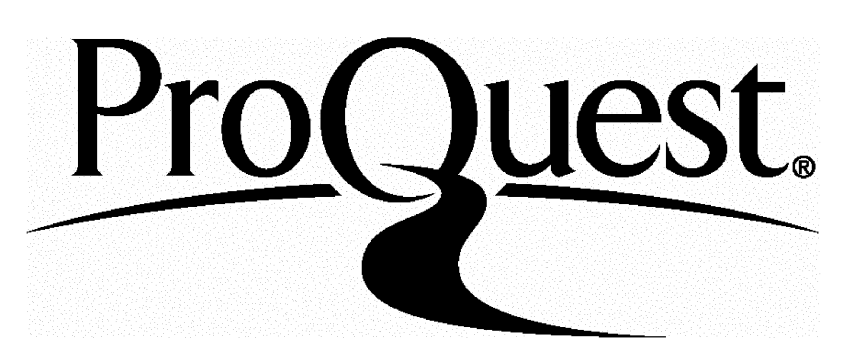

ProQuest U122782

Published by ProQuest LLC(2016). Copyright of the Dissertation is held by the Author.

All rights reserved.

This work is protected against unauthorized copying under Title 17, United States Code. Microform Edition (c) ProQuest LLC.

\author{
ProQuest LLC \\ 789 East Eisenhower Parkway \\ P.O. Box 1346 \\ Ann Arbor, MI 48106-1346
}




\section{Contents}

Abstract

3

Chapter I

Introduction and Literature Review

4

Chapter II

Definitions of $S k a z$

25

Chapter III

A History of Skaz

68

Chapter IV

The Evolution of Zoshchenko's Art: Early Work

110

Chapter V

Zoshchenko's Skaz and Journalism

129

Chapter VI

Zoshchenko's Skaz Narration

180

Conclusion

208

Notes

211

Bibliography

246 


\title{
Mikhail Zoshchenko and the Poetics of Skaz
}

\begin{abstract}
The reputation of Soviet writer Mikhail Zoshchenko (1894-1958) was built and still stands upon his short stories of the 1920s. Their force derives from their most distinctive characteristic: they are told in the colloquial language of the people. This is called the skaz narrative manner and critics have associated the term with Zoshchenko from the beginning of his career. Nevertheless, as I argue in Chapter I, inadequate understanding of skaz has hampered study of his work. My thesis grounds its analysis of Mikhail Zoshchenko's 1920s short stories in an examination of theoretical treatments of the skaz technique (Chapter II) and a survey of its previous uses in Russian literature (Chapter III).

Investigation of the definitions of skaz leads me to develop Mikhail Bakhtin's account of the term. Bakhtin divided the technique into parody and stylisation according to the author's intention in recreating another person's style and point of view. This approach is flexible enough to account for writers' divergent uses of the technique, and for readers' contradictory interpretations of them.

Zoshchenko's use of skaz combines parody and stylisation. I illustrate this in Chapter IV by showing how Zoshchenko evolved this way of writing and in Chapter $\mathrm{V}$, by relating it to 1920 s Soviet journalism. Zoshchenko's reproduction of the feuilleton and letter of complaint forms is sympathetic stylisation aimed at cultural democratisation as well as parody. The same holds true of his language. Moreover, as I show in Chapter VI, the writer has a similarly ambivalent relation to his narrator's mentality: the concrete experiences that serve as the stories' material contradict the optimistic interpretations the narrator makes on the basis of those experiences. Zoshchenko himself is demonstrably unsure whether to trust the narrator's experience or his interpretation. The competing claims of interpretation and experience coexist precariously through Zoshchenko's exploitation of the inherent duality of skaz. His later works tend to resolve this conflict and forfeit any such balance.
\end{abstract}




\section{Chapter I}

\section{Introduction and Literature Review}

To many readers of his short stories, Mikhail Zoshchenko is a wonderfully simple, funny writer. Zoshchenko, it would seem, is an artist without the slightest need of a doctoral thesis about him. But humour itself is a funny thing. Or rather, with Zoshchenko it is frequently no laughing matter, since his stories often leave us feeling sad rather than happy. We may start to wonder why they do this. In attempting to respond, we are likely to pose further questions: how far does Zoshchenko himself share the views and sympathise with the fate of the characters and narrators of his stories? Maybe we are being invited to cry rather than laugh; or to laugh with rather than at the characters. These questions may be summed up as 'what is Zoshchenko's own relation to his stories' characters and narrators?' This is the most important question to ask of Zoshchenko's short stories, but the hardest to answer. As a consequence, Zoshchenko's readers have tended to supply different responses from his critics, and the critics themselves have occupied a broad span of positions.

The difficulty of defining Zoshchenko's relation to his narrator, supplying a general account of his many stories, and of furthering our understanding of the place of Zoshchenko's short stories within his work as a whole, has also led many critics to unify and simplify Zoshchenko's artistic achievement. Too often, in the search for a coherent set of deeper concerns underpinning the work, critics have been willing to dismiss their comic nature as a superficial level of the Zoshchenko short story. In a similar way, there has been a tendency to see Zoshchenko's use of a characternarrator as an incidental aspect of Zoshchenko's form, as an ironic mask to be torn away to reveal the author's true face. Nevertheless, we must strive not to forget their most distinctive and attractive feature: their humour. The failure to value the stories' humour is linked to the failure to value their narrative form because the humour is 
overwhelmingly produced by Zoshchenko's use of and relation to a characternarrator. That is to say it is generated by his use of a skaz narrator.

Critics treating the question of Zoshchenko's relation to his narrator have tended to see the writer as similar or as precisely opposite to his narrator. However, no one has explored with any rigour the idea that Zoshchenko has a mixed relation of sympathy and antipathy for his narrator. To describe the author-narrator relation in this way would enable us to account for contradictions running throughout Zoshchenko's short stories. It would also go some way towards explaining their profound tragi-comic power. This humour, and the narrative form that generates it, is inextricable from Zoshchenko's world-view, and constitutes the pinnacle of his artistic achievement.

Yet Zoshchenko did not invent the skaz narrative form that he employed. In order to understand Zoshchenko's use of the skaz narrative form, we must first investigate its nature, definitions of it and its history in general. This thesis is an attempt to further knowledge with regard to both skaz and Zoshchenko. I consider that my development of Bakhtin's definition of skaz as a double-voiced form, and my relating of it to debates about irony, parody and authorial intention, represent an advance in our understanding of the skaz form. This sharpened definition of skaz enables me better to describe the combination of sincerity and parody in Zoshchenko's skaz in particular, and in his short stories of the 1920s in general. These mixed motives are made especially clear when related to the context of 1920 s journalism, where Zoshchenko found sources for the language and mentality of his characters and the forms of his stories. By reproducing letters that, I contend, served as his sources, and examining Zoshchenko's reworking of them into stories, I believe I have made an original contribution to our appreciation of Zoshchenko's art.

First, we must investigate how the critics' approach to or avoidance of the question of skaz has influenced their views of Zoshchenko's relation to his narrator. Needless to say, in doing this I shall be attentive to the critics' genuine achievements in furthering our appreciation of Zoshchenko and his art. 
Anatolii Starkov is a good example of a critic who argues that Zoshchenko's own position is opposite to that of his narrator. Starkov's interpretation is grounded in a definition of skaz as the satirical use of irony, and an understanding of irony as antiphrasis. In particular, Starkov characterises Zoshchenko as using siuzhetnaia ironiia (the irony of plot) to comment on his characters. ${ }^{1}$ Similarly, Starkov argues that the narrator's inadequate or distorted understanding of a significant question discredits him: ${ }^{2}$

\footnotetext{
Большая, актуальная для тех лет тема (борьба со взяточничеством, бюрохратизмом и пережитками в быту, создание советской авиации и другие) вводится в рассказ в нарочито искаженном, подчас курьезном осмыслении героя. В результате дисхредитируется не тема а герой. Его искаженное восприятие новой действительности как бы накладывается на обычное, нормальное восприятие ее читателем, и герой сам себя же и разоблачает $^{3}$
}

The critic here employs two approaches that crop up frequently in discussions of skaz and Zoshchenko's narrator. The first is the idea of a reader with a normal understanding of events who, he contends, corrects the narrator's abnormal views. The effect is to discredit the narrator's understanding of the issue and not the issue itself. This notion is almost invariably accompanied by a view of an implicit norm language, from which all skaz is a deviation, and therefore parodic.

The second is the very idea of a choice between trusting the narrator or the issue. Starkov immediately concentrates on the untrustworthy way in which the narrator evaluates, and takes this as meaning that the narrator, rather than the issue, is being satirised. In fact we are far freer than Starkov thinks. Zoshchenko's skaz leaves it to us to choose whether to place our trust in the issue, what might also be called the generalisation, or to trust the narrator. 
Starkov bases his conclusion upon a notion of how an author makes his own point of view known when employing a character-narrator, i.e. when employing skaz. Indeed, at certain points, the critic argues that Zoshchenko has an ambivalent attitude to his narrator, but his resolution of the questions of skaz and irony lead him to banish all such ambiguity in his readings of the stories and in his conclusions. Starkov's conception of skaz is as a deviation from a norm, and its meaning can only be established by reference to an implicit norm. Yet the history of $s k a z$, as we shall see, shows us that not all skaz exists in contrast to a norm. Some of it is part of a deliberate attempt to redefine the norm. It would be ridiculous to judge a serious attempt to redefine literary genre and style, such as Andrei Belyi's Peterburg, as a satire on the genre and style that it employs from the point of view of the literary norm. ${ }^{4}$

This understanding of skaz as a deviation from normal attitudes or the norm language leads to seeing all skaz as a form of parody employed to ridicule the language of the narrator, or as a form of irony used to ridicule his outlook and imply the opposite.

This view unites critics of different political persuasions. Thus, during the Cold War it was held by both Soviet critics such as Starkov, in part writing to ensure that Zoshchenko could be further printed and studied, and Western critics, such as Mikhail Kreps, trying to appeal to the imagination of readers receptive to the image of Soviet writers as conscience and victim of an oppressive society. Despite appearing irreconcilable, these stances share the common goal of presenting Zoshchenko as a satirist consistently ridiculing the vice or stupidity of his character-narrator. Though their political imperatives are different, critics such as Starkov and Kreps agree on the importance of determining a writer's politics and derive Zoshchenko's own position by reversing that of his narrator. ${ }^{5}$

Such a view of Zoshchenko as parodying or satirising his narrator need not be informed by political imperatives. Iurii Shcheglov stresses the cultural aspect of Zoshchenko's character-narrator. ${ }^{6}$ This critic sees him as the new, cultureless man of 
the Revolution, only presented in a comic light and parodied as a militant vulgarian. Ultimately then, Shcheglov, like Kreps, sees Zoshchenko solely as a satirist of Soviet society. They disagree over the object of that satire.

Shcheglov convincingly describes Zoshchenko's character as transgressing all conventions of polite behaviour. He also ably catalogues the various ways in which the crude triumphs over the sophisticated in these stories. By his designation of Zoshchenko's work as an encyclopaedia, it seems Shcheglov is implying that Zoshchenko is describing a phenomenon neutrally. At the same time, Shcheglov does see the need to account for the fact that the stories are comic. This he does by reference to Zoshchenko's article, 'O sebe, o kritikakh, i o svoei rabote' (1927), arguing that the character-narrator is presented in a comic light because he portrays a hypothetical average worker who was also a writer: the genuine proletarian writer who cannot yet exist.

A more thorough examination of Zoshchenko's non-fictional statements shows us that he has a great deal of sympathy for the language and forms that his narrator uses. Moreover, he is attracted to the very simplicity and lack of sophistication that Shcheglov has described in the character-narrator. Zoshchenko then is ambivalent to his character-narrator; he is not just parodying him, but also reproducing his attitudes and speech with a considerable degree of sympathy.

The account of Zoshchenko's relation to his narrator as simply a satirical one is plainly inadequate. This is highlighted in particular by those critics who have taken the opposite view and attempted to explore the similarities between Zoshchenko and his narrator. Soviet critics of the 1920s and 1930s such as Georgii Gorbachev argued that Zoshchenko had much in common with his narrator, and was thus guilty of tainting everything with vulgarity, of having a taste for the ugly sides of life, and of tending to distort reality by denuding it of historical meaning. ${ }^{7}$ This was a way of condemning him as trivial or as a philistine, and ultimately as anti-Soviet. Hence Zoshchenko appears in the section of Gorbachev's book devoted to petit-bourgeois writers. Such interpretations led Zoshchenko to exclaim in September 1929: 


\section{меня (последний год) ругают - за мещанство! (...) Тему путают с автором. Не могу же я $\mathbf{x}$ каждому рассказу прилагать учебник словесности. $^{8}$}

Recently, but with less sinister motives, there has been renewed interest in exploring the degree to which Zoshchenko is sympathetic to his narrator. Benedikt Sarnov argues that Zoshchenko is sympathetic to his narrator's uncouth language and vulgar materialism. ${ }^{9}$ Sarnov rejects the view that Zoshchenko's work was parodic in purpose. Such a view is based, he contends, on the assumption that Zoshchenko was writing for people of the old culture, and not the new; it assumes that revolutionary reality is being ridiculed from a perspective that takes pre-revolutionary life as the norm. Sarnov points to the response of his readers in Pis'ma k pisateliu as evidence of the erroneous nature of that assumption. Zoshchenko wanted to write for the new readers in their language:

\footnotetext{
Зощенко далеко не всегда смеется над своими героями. Сплош и рядом у него не только нет ни малейшего желания издеваться над ними, но даже наоборот: в его отношении $\mathbf{x}$ ним явно преобладает сочувствие, интерес, а порой и самое искреннее восхищение. ${ }^{10}$
}

The reasons for this sympathy, Sarnov argues, lie in the fact that Zoshchenko believed that the old literature was irrelevant, and that it was his duty to respond to the new cultural situation by learning from the new Soviet man. This new man was selfish, materialist and amoral to the utmost degree and Zoshchenko depicts him as such. As a writer, the new man was a kind of modern version of Captain Lebiadkin, the Dostoevskii character whose poems were denunciations and visions of infinite self-interest. 
Nevertheless, despite redressing an imbalance, Sarnov smudges the boundaries between representation and sympathy so as to exaggerate the extent to which Zoshchenko was sincere and sympathetic to his narrator. Moreover, despite predominantly arguing the opposite, he contradicts himself by claiming that Zoshchenko's language also serves to ridicule the narrator. Ultimately then, Sarnov realises that his view is in fact only part of the story, but is unable adequately to describe and still less to account for Zoshchenko's contradictions. Such a shortcoming is the inevitable result of failing to set up an adequate analytical structure for the description of author - narrator relations in Zoshchenko, and the failure to address the influence of formal and generic traditions upon this relation.

A number of other recent attempts to suggest Zoshchenko's similarities with his narrator have been more rigorous. Like Sarnov, Alexander Zholkovsky sees similarities between Zoshchenko and his character-narrator, but the similarities are quite different. Zholkovsky argues that Zoshchenko expresses his own neuroses in his narrator, and that an analysis of that character in the light of the autobiographical story, Pered voskhodom solntsa, can serve to unify Zoshchenko's work. ${ }^{11}$

Yet despite the fact that Zoshchenko became increasingly interested in psychoanalysis, a reading of his works as a pathological confession leads to a number of distortions. Zholkovsky's psychoanalytical reading sees the stories' humour as a defence mechanism serving to shield the author's neuroses. ${ }^{12}$ Similarly, Zholkovsky sees the narrator's unreliability as an indication of the stories' psychological content, as further evidence of Zoshchenko's unfounded fear, guilt and suspicion that can be perceived primarily in the plots. ${ }^{13}$ According to Zholkovsky, Zoshchenko's characters already perceive themselves as guilty, and await punishment for a kind of psychoanalytical version of original sin.

This view attempts to dispense with the formal and cultural indeterminacies of Zoshchenko's stories and resolves Zoshchenko's contradictory mixture of sincerity and irony to a means of psychological camouflage. In order to arrive at a consistent account of Zoshchenko, the form and the humour of the 1920s stories are denigrated 
and seen as accidental, a by-product of the psychological content of the stories' plots. Moreover, Zholkovsky assumes the narrator's fears to be Zoshchenko's, but never adequately deals with the possibility that Zoshchenko is ridiculing those fears. In his haste to escape from the politically informed view of Zoshchenko as a satirist, Zholkovsky fails adequately to address the problem of the stories' form.

However, we do not have to reduce the formal indiscrepancies of the stories to a purported psychological content. We can come to an understanding of Zoshchenko's world-view by investigating the very nature of the form that he chooses. Zoshchenko's formal choices hold the key to the question of his relation to his narrator. All other analyses come up against this question whether they decide to confront it or not. Only from an examination of these choices can we infer his worldview, since to act otherwise is to treat the form of Zoshchenko's short stories as both unimportant and transparent. It is neither. Zoshchenko's form is an embodiment of his philosophy.

Nevertheless, freed from its psychoanalytical bondage, Zholkovsky's thought raises some important imperatives for the contemporary study of Zoshchenko. We need to stop trying to define Zoshchenko in constricting terms established by the Cold War. Instead, we need to define his artistic position, his world-view. ${ }^{14}$ This task is posed in part by the disappearance of the Soviet Union: we have to ask whether he is a writer only worth reading for a satirical portrait of the 1920 s, the Soviet Union and Soviet Marxism. In other words, will his work stand the test of time as a 'nonconformist Soviet-classic', like Bulgakov? If we do not intend to jettison the notion of 'classics', in the pursuit of freedom from authority and authorial interference in the reader's right to interpret, then the need to reconsider our view of Zoshchenko becomes more pressing as the concrete experience and memories of the 1920s and the Soviet Union become more distant. Zholkovsky reevaluates Zoshchenko through the short cut of initially stripping all cultural context from the writer, leaving only his psychological complexes. He then argues that it is Zoshchenko's fear that both makes him a writer that transcends his epoch, and 
enables him to be a perfect representative of it. ${ }^{15}$ This approach is compelling in that it sees the historical and personal specificity of Zoshchenko's art as the basis for its super-historical and inter-personal appeal. Yet even if we accept this as a standard for judging the lasting historical value of a work, it is not solely an author's psychological specificities that guarantee such value. This thesis will attempt to meet that criterion of enduring worth by demonstrating perennial themes in the humorous discrepancies of Zoshchenko's style itself: it is the expression of a profound philosophical problem.

Another merit of Zholkovsky's approach is that it attempts to unify the comic short stories of the 1920s and the quite different, semi-autobiographical, Pered voskhodom solntsa. Unfortunately the effect of doing this is to impose a hierarchy in which Pered voskhodom solntsa works as a key to the short stories, and their specific merits are sacrificed on the altar of interpretation. This is a paradox, since the genius and comic essence of the early stories is precisely their insistence on the lack of correspondence between the claims and attractions of interpretive abstraction on the one hand and on the other, the reality of the experience and the event. They leave the reader with the choice as to whether to trust the experience or the interpretation of it. In contrast, Pered voskhodom solntsa makes experience and interpretation dovetail by smoothing over experience. One way in which it does this is through the creation of a more trustworthy, irony-free narrator figure. The effect is sincerity. This is why critics feel confident using Pered voskhodom solnts a as a stable beginning for an interpretation of Zoshchenko.

Linda Hart Scatton also stresses the continuity in Zoshchenko's work and sees Zoshchenko as broadly sympathetic to the character-narrator and his language. Scatton discerns underlying Zoshchenko's work a consistent view of human beings as self-centred but stubbornly adaptable and opportunistic creatures, who when they know what must be done to make their environment comfortable, do it. According to Scatton, Zoshchenko perceives that it is impossible to change the human personality through politics or social influence, and that it can only be changed from within. The 
characters of the early stories are striving for the same thing as Volosatov in Vozvrashchennnaia molodost' and Zoshchenko himself is searching for in Pered voskhodom solntsa. They all want to make their lives more bearable. The only difference between the characters of the early stories and those of the later works is that the former are not thinkers and therefore cannot find the key to making their lives less painful and more bearable.

Scatton also argues that Zoshchenko was always didactic, and in his early stories he used satire to ridicule vice with didactic intent. Having grown in confidence as an artist, in his later works Zoshchenko offered the same ideas only 'unsweetened by humor'. ${ }^{16}$ Central to Scatton's thesis is the notion that there is a stable content that runs throughout Zoshchenko's works. It can be detached from its expression through the short story, through irony and humour, since they are incidental to his fundamental message. Scatton appears to misread Zoshchenko's humour, since she presents it almost as a joyful laughter free from melancholy. This whole reading is posited upon a view of humour as inferior to and less significant than sincerity. Moreover, it implies a conception of form as a kind of container, from which content can be removed unharmed. I cannot endorse such a view, and believe that forms such as those of the haiku or limerick exert a profound influence upon their content. Likewise, I consider the value of Zoshchenko's art to be bound up with its forms of expression.

Like Zholkovsky, Scatton attempts to develop a view of Zoshchenko's art and world-view that is capable of accounting for his evolution, and thus uniting his whole oeuvre. However, as he does, she subordinates one part of the writer's work to another, and arrives at an account of the whole that obliterates the distinctive character of the parts.

The merits of the critics who saw irony as antiphrasis, such as Starkov, are clear in retrospect. At least they took the comic form of the short stories seriously, as other than a sweetener or a form of neurosis. Yet they too ultimately saw the discrepancies in the narrative manner as not in themselves significant, but more of a veil covering 
the truth. None of these critics has seen the form as significant in itself. None of them has asked themselves whether this manner was not in itself an essential and irreducible part of whatever truth the stories contain.

Marietta Chudakova comes closest to describing Zoshchenko's use of the skaz form in such a way as to arrive at his world-view. However, her monograph concentrates on describing the evolution of Zoshchenko's style and she too tends to stress skaz as parody. Chudakova argues that the short stories of 1925-29 parody the new proletarian author, so that the author figure becomes both object of parody and a parodying consciousness, both a quotation and quoting consciousness. This subtle formulation may appear to give us a glimpse of the description of Zoshchenko's contradictions that we have been looking for. However, on closer inspection, it turns out that really this is just a way of describing the fact that Zoshchenko uses a character-narrator, i.e. skaz. Chudakova sees the absence of a neutral authoritative narrative voice in Zoshchenko's short stories of the 1920s as a consequence of the general impossibility of authoritative narrative discourse in the 1920 s. The language that he is using is an expression of the crisis of authoritative discourse, and the impossibility of expressing oneself clearly and seriously at the time. ${ }^{17}$ For Chudakova, Zoshchenko's parodic language is really just highlighting the already ridiculous nature of the language of the time rather than granting any insight into his world-view. Ultimately, Chudakova does not perceive any trace of a sympathetic attitude to the narrator. Thus she fails to elaborate a description of Zoshchenko's skaz capable of adequately describing the contradictory processes at work in a Zoshchenko short story.

Zholkovsky and Scatton have not been the only critics willing to contest the longstanding concentration of critical attention on Zoshchenko's narrative manner typical of the critics who see Zoshchenko as ironic. Cathy Popkin takes Chudakova to task for arguing that narrative manner alone is significant. Popkin argues that Zoshchenko's plots are of paramount significance: like Tolstoi and Chekhov before 
him, Zoshchenko redefines the parameters of the significant or 'narratable' event, through the length and plots of his stories. This, she argues, is a subversive 'trivialisation of what was held in official esteem'. ${ }^{18}$

Though Popkin's comments about the plots of Zoshchenko's stories are thoughtprovoking, they are diminished by the fact that she ignores the significant questions of genre and narrative voice. The size of Zoshchenko's stories seems less 'insignificant' or subversive when put in the context of other feuilletons and letters of complaint than when placed in the context of the Russian literary tradition. Moreover, the way in which we know the plot is through the narrator: the plot does not exist independent of narrative form. The narrator relates the plot, and in the case of the narrator-participant, this is also his experience. That experience then comes into conflict with the narrator's own generalisation about it. Ultimately, the plots can be seen to be revealing as to the narrator's rather than as to the author's vision of the world. Zoshchenko, on this reading, would be a writer with a sincere belief that bigger means better, who satirises opponents of the gigantesque. Popkin, on more rigorous scrutiny, turns out to be another commentator who has attempted to side step the question of the narrator-author relation. But when read from this very perspective, her thesis is found wanting.

However, not all critics have resolved Zoshchenko's contradictory narrative form into a coherent world-view, or simply attempted to ignore it. Some have unwittingly or unwillingly raised the possibility of his ambiguity, or ambivalence. Some have even embraced it. However, no one has yet developed such a view into an extensive piece of research (the purpose of this thesis). On the contrary, the smaller the piece of work, the greater the chance that the critic pointed to the contradictory nature of Zoshchenko's art. The main reason for this is that it is easier to express a paradox in passing, possibly in the form of an epigram. Longer works, such as the monographlength study, have typically pursued the ideal of systematic rigour and achieved it at the price of the paradox at the heart of Zoshchenko's own work. 
Maksim Gor'kii was one of the first people to point to the ambivalence in Zoshchenko's stories:

\section{Данные сатирика у вас - налищо, чувство иронии очень острое и лирика сопровождает его крайне оритинально. Тахого соотношения иронии и лирики я не знаю в литературе ни у хого ${ }^{19}$}

Similarly, Kornei Chukovskii also thought that Zoshchenko's best stories combine joy and sadness:

Тах между двумя крайностями он постоянно метался: между «угрюмством» и смехом. Метался и в жизни, и в творчестве. И, конечно, смех побеждал не всегда. Угрюмство зачастую не хотело сдаваться, и тогда у Зощенко возникали рассказы, где смех сосуществует с тоской. Веселость в сочетании с грустью - этим сложным чувством, которое, в сущности, и назьвается юмором, охрашены лучшие произведения 3ощенко. ${ }^{20}$

Galina Belaia's investigation into the underlying reasons for the stylistic shifts of the 1920 s begins to explore these contradictions. Initially, she takes a view similar to Starkov's, arguing that where there is a conflict between the big idea and the narrator's understanding of it, it is not the big idea, but the narrator who is at fault. ${ }^{21}$ Zoshchenko, she argues, was struck by the gulf between the scale of the Revolution and the everyday, the conservatism of the human psyche. He chose the Revolution. Thus, the meshchanin's language is a means of ridiculing him, of creating an irony that enables Zoshchenko to rise above this byt. Zoshchenko stands on the side of interpretation and bytie. His whole purpose is to expose the meshchanstvo of these characters and to overcome byt. 
But Belaia also develops a deeper insight into this conflict as one between byt and bytie: between the striving to incorporate the new reality and the need to interpret that reality. Writers in the early twenties sought new forms capable of doing both adequately. The critic sees Zoshchenko's meshchanin as a creature of byt, as the negative side of the small man. Skaz was good at incorporating the new, but poor at interpreting it. Belaia sees Zoshchenko as exemplifying an extreme pole of the dominance of the discourse of the character, which was a general characteristic of the 1920s. The danger inherent in the use of the skaz form to introduce the new reality was that it brought with it the unwanted additional baggage of byt. Belaia argues that Zoshchenko ultimately found this an inadequate solution and began to search for forms more capable of expressing an authorial position more directly, of imposing interpretation.

At the same time, Belaia is an example of a critic who sees in Zoshchenko a certain duality. She argues that in the Sentimental'nye povesti, Zoshchenko uses his irony for the opposite purpose of satirising the ideas, the abstractions themselves:

\section{Саркастичность интонации подчеркивает ту принципиально осознанную невозможность мыслить высокими идеологическими категориями, которые Зощенко отвергал как отвлеченные, абстрактные, чуждые «простому человеку» понятия. ${ }^{22}$}

She argues that Zoshchenko is particularly hostile to the abstract concepts that invaded the lexicon in the 1920s. At the same time she contends that the characternarrators of the Sentimental nye povesti are attracted to these questions. In other words, she detects a certain duality of authorial attitude or a duality in the characternarrators themselves. Strangely, this duality is claimed only for the Sentimental'nye povesti.

More recently, in an article of 1995, Belaia changes her position to emphasise Zoshchenko's hostility to abstract concepts, and says nothing of her previous viewthat 
Zoshchenko was ridiculing the narrators who were unable to live up to these big ideas. ${ }^{23}$ Now she sees the ironic treatment of ideas as suggesting an existentialist insight into the unsuitability of big ideas as such for the fragmentary nature of life. Zoshchenko himself, according to this account, is now on the side of byt and not bytie. However, though this view apparently refers to the whole of Zoshchenko's work, she selects her examples overwhelmingly from Sentimental'nye povesti.

Despite the rich, stimulating subtlety of her analysis, Belaia is unable adequately to account for both aspects of Zoshchenko. Rather than incorporate them as two inherent tendencies that exist in conflict throughout his short stories, she consecutively stresses one aspect of his work, then the other. Moreover, her analysis depends overwhelmingly on the Sentimental'nye povesti, stories in which the philosophy is quite explicit. Neither does she consider the contradiction between Zoshchenko's hostility to big ideas and his attraction to them as determining the stories' form.

The critic and translator, Hugh McLean, similarly detects a certain ambiguity in Zoshchenko's skaz:

'Debased' language combined with naïveté of thought implies that the author's attitude toward his apparent spokesman is tinged with irony, and we naturally conclude that the narrator's ideas are to be regarded with scepticism. But we cannot be sure. Sometimes 'naïve' remarks, like the child's observation about the emperor's clothes, have a way of striking taboo targets. $^{24}$

Ultimately though, McLean sees this uncertainty fostered in the mind of the reader as part of the Aesopian language, a way of outwitting the censor. For McLean, there is no question of Zoshchenko having intrinsic sympathy for this narrator, his language, or his mentality and world-view. 
More recently, in the context of a discussion of Bakhtin, M. Keith Booker and Dubravka Juraga have argued that Zoshchenko's readers can choose whether to see the narrators as objects of praise or of ridicule. However, the critics consider this choice to be primarily political and conduct little analysis of Zoshchenko's stories. ${ }^{25}$

One of the first critics to argue that Zoshchenko's form is essentially ambiguous is Vladimir Novikov. Novikov stresses Zoshchenko's duality, and argues against the view of Zoshchenko as a satirist using destructive irony as antiphrasis. ${ }^{26}$ Instead he attempts to place Zoshchenko within a tradition of Russian literature in which the comic and serious are entwined. In this 'dialogic writing', which includes Dostoevskii and Pushkin's Povesti Belkina, Novikov stresses the generative power of the comic:

\section{Комические приемы нередко вьполняли позитивно-созидательную Функцию, помогали моделировать авторские духовные идеалы. Смех ахтивно участвовал в выработхе новых, эстетичесхи продухтивных художественных конструкций - сюжетных, образных, языковых. Причем неизменной плодотворностью обладала в русской литературе сама неопределенность, подвижность гранищ «смешного» и «серьезного», что давало большие возможности для обретения художественного двуголосия, для парадоксального сцепления антонимических смыслов, для диалектической игры взаимоисключающими точками зрения, для построения сложного диалога. ${ }^{27}$}

Novikov also objects to Sarnov's attempts to identify Zoshchenko with his narrator. He refuses to see Zoshchenko's artistic achievement in narrowly political terms. Instead he stresses that Zoshchenko's hero is primarily an aesthetic structure. Moreover, he rejects on principle all attempts to understand the 'hero' by comparing his with the writer's own views. The character may resemble Zoshchenko himself, argues Novikov, but that is because he resembles us all. The author's relation with that hero is that of a complex dialogue, with a 'paradoxical interpenetration': 


\section{Подобно своим предшественникам, Зощенко доститает за счет комико- иронического раздвоения образа рассказчика особенного, чисто} эстетического удвоения художественного эффекта. ${ }^{28}$

This view seems to me extremely productive. Nevertheless, it has not been developed. The nature of the dialogue between author and character-narrator is never defined other than by pointing to its duality. Moreover it is not illustrated. We need to know in what respects the narrator is serious and in what respects ironic. We need to know how the irony functions in relation to the stories and their structure, but Novikov does not seem willing to go into this question in any greater depth. One reason for this may be that he has already ruled out comparing the author's own views with those of the narrator. As we shall see in the examination of the theory of $s k a z$, this is one of the most effective ways to investigate irony, and a crucial indicator of the difference between ironic and sincere uses of skaz.

Furthermore, it seems to me that there can be no such thing as a purely aesthetic anything. Zoshchenko's artistic duality is of course also intimately bound up with political as well as other sympathies. The fact that Zoshchenko has previously been reduced to the question of his political attitude does not mean that it is irrelevant, or that we have the right to discount its importance altogether. He was writing and working in a highly politicised society. Politics is likely to have some influence upon the question of his attitude to his narrator.

One recent Western study, that of Gregory Carleton, has made the ambiguity of Zoshchenko's stories central. ${ }^{29}$ Carleton sees Zoshchenko's texts as contradictory in that they cannot be exclusively interpreted either as parody nor simply as (sincere) documentary. He argues that we have no clear guidelines as to which interpretive protocol to employ and as a consequence the texts subvert all possibility of reference to a reality outside themselves. 
To illustrate his point, Carleton examines a number of texts, including 'Drova' (1925), Pis'ma k pisateliu (1929), and 'O sebe, ob ideologii, i eshche koe o chem', (1922), and argues that the parody of a non-fictional text subverts its authority as documentary. This claim is crucial, since on it Carleton bases his fundamental thesis. In other words, ultimately he founds his analysis of Zoshchenko on a notion of parody as subtraction. For Carleton, to parody and play with genres is terminally to undermine the referential capacity of language, and sunder it from everything outside itself. A parodied document is all parody, no document, and consequently wholly self-referential. For Carleton, the debates surrounding Zoshchenko's work are proof of its attack on mimetic structures, and on the very possibilities of referential adequacy.

It seems to me that Carleton not only misunderstands the nature of parody, but also the historical context of 1920s documentary forms. He argues that documentary and parody cannot be combined:

The two narrative modes are inherently antithetical: one presumes the author's 'hand' to be minimal, self-effacing so as to effect a transparent reproduction; the other operates in the exact opposite direction. ${ }^{30}$

In fact, as we shall see, the documentary forms of the 1920 s permitted a large degree of authorial interference. Moreover, at no point does Zoshchenko say that he has deformed everything. In fact he only distorts to a minimal degree.

Furthermore, Carleton ignores the possibility of a third term, that of stylisation, introduced into the theory of skaz by Bakhtin. The term stylisation suggests a more sympathetic form of reproduction of a style than parody. Through stylisation, Zoshchenko sincerely reproduces fundamental elements of Soviet satirical genres. In his short stories of the 1920s that employ the skaz form, there is also an element of parody, but the two moments do not cancel each other out. Rather they exist in an uneasy and dynamic tension. For Carleton, there can be no combining stylisation and 
parody in skaz: a text is either one or the other, and since Zoshchenko's texts are both, Carleton sees them as neither. The nature of the interrelation between parody, stylisation and documentary in Zoshchenko can only be perceived by relating it to the skaz narrative form and to the letter of complaint and feuilleton genres.

Carleton takes a similar approach in examining the question of skaz: all ambiguity or contradiction is seen as an attack on representation. The critic claims that the mixture of different registers of speech in previous skaz was unambiguous because they were clearly demarcated. Zoshchenko by contrast, mixes registers up, and by so doing subverts the status of any voice in the text. For Carleton, this mixture of different registers is such that the language could not be that of one person. Thus Zoshchenko's character-narrators are not characters at all, but a diversity of voices even within a given story. Every aspect of skaz, including of course its use of a narrator who is as unreliable as a character, is seen as leading us to question the text's representational value.

It seems to me that Carleton is absolutely right when he perceives that the stories have no 'accessible, univalent authorial presence that would resolve the recurring problem of establishing the writer's "true meaning". ${ }^{31}$ However, the absence of a univalent authorial presence does not mean the absence of meaning, representation or even of an authorial presence. This seems to me to be a drastic and unfounded conclusion: surely it takes more than a partial and limited narrator to undermine the whole assumption that the text represents something outside itself.

Carleton sets up univalent, monological coherence as a model for meaning, and when Zoshchenko's texts are found to fall short of this standard, they are triumphantly declared meaningless, or subversive of meaning.

However, it seems to me that we can rescue them from this plight by defining them as dialogical. The documentary and the parodic principles are both at work; they are in constant dialogue. If we keep our focus firmly on the genre characteristics, the language, and the figure of the narrator in Zoshchenko's short stories, that is to say on skaz, I believe that we need not succumb to this interpretive despair. Through an 
analysis first of the nature of skaz and a review of its previous uses we can then understand how Zoshchenko uses it and to what purpose. In this way we can better understand Zoshchenko's own position in relation to his work.

\section{Conclusion}

Understandings of the author-narrator relation in Zoshchenko are either informed by an investigation of the question of skaz, or attempt to overlook it, only for it later to return and undermine them. However, Chudakova and Kreps are the only studies of Zoshchenko's short stories of the 1920s that also examine skaz in any depth. These studies, as we have seen, interpret both skaz and Zoshchenko's use of it as solely parodic.

This seems an omission given that almost every study of Zoshchenko pays considerable attention to his use of a skaz narrator in his short stories of the 1920s. Zhurbina was not the first to state, when she wrote in the 1930 edition of Zoshchenko's collected works: 'Literaturnaia sud'ba Zoshchenko sviazana so "skazom",.$^{32}$ The grounding of a reading of Zoshchenko's short stories of the 1920s in a thorough understanding of skaz is a project that demands both a reading of Zoshchenko that adds to our understanding of him, and an analysis of skaz that furthers our understanding of it. It is my contention that by first understanding skaz, and drawing on this knowledge to understand the relation between Zoshchenko's narrator and his author, we can reconcile the two main trends in Zoshchenko criticism and better understand Zoshchenko.

Recent criticism, such as that of Popkin, Zholkovsky, Sarnov and Scatton, has tended to relegate the importance of skaz in Zoshchenko's work. Zholkovsky has stated clearly that the end of the Cold War opens the question of Zoshchenko's entry into the post-Soviet literary canon and imposes the need to read Zoshchenko in a different way. He should no longer be read solely as a satirist, but also for his positive programme; not only for his relation to the $1920 \mathrm{~s}$, but also to 'eternal' themes. It is this challenge to which I intend to respond in this thesis. However, the 'eternal', or 
shall we say enduring, quality of Zoshchenko, that which transcends his age and makes him worth reading not solely for his satire of Soviet conditions, does not lie in his neuroses, or some world-view separable from his narrative manner. Rather, it consists in the ambivalent humour created through his very use of the skaz form. 


\section{Chapter II}

\section{Definitions of $S k a z$}

Skaz is a term that has been interpreted and employed in many different ways. Consequently, in order to understand $s k a z$, we must first examine the history of these often conflicting definitions. In doing so our purpose is to discover or derive an account of skaz with which to describe its use both by Zoshchenko and by other writers.

\section{Skaz: From Folklore to Literary Criticism}

Skaz began life innocently referring to a folkloric genre. According to Vladimir Dal's 1881 dictionary, skaz is an Orel or Kaluga word for a story called a skazanie in other parts. ${ }^{1}$ At this point, skaz referred to a genre of folklore, in that it was a story related by a member of the 'folk', but a genre without clear generic characteristics. In other words it was a bin in which to dump folk stories that did not fit other genre specifications, such as those of the skazka. This vagueness may well have been what attracted writers to the term and its idyllic pre-literary life soon ended. In the same year, Nikolai Leskov, himself from the Orel region, called his story better known as 'Levsha' 'Skaz o tul'skom kosom Levshe i o stal'noi blokhe'. The assimilation of $s k a z$ from folklore to literature had begun. It is perhaps this unstable position of $s k a z$, between literature and folklore, combining the written and spoken languages, that explains its enduring fascination for writers, particularly in periods when the literary language itself was undergoing change. The 1920s was one such period, and Zoshchenko exploited these indeterminacies to a far greater extent than any previous practitioner of $s k a z$ had done.

It was not long before literary critics too began appropriating the term. ${ }^{2}$ Boris Eikhenbaum's articles of 1918 were the first of many such examples. What marks skaz out from many of the Formalists' other coinages, such as zaum' and ostranenie, 
is precisely the fact that it was not a neologism. Its folkloric associations meant that when Eikhenbaum chose the term skaz to describe a literary form, he simply added a further layer of meaning to an already ambiguous term. This process did not stop with Eikhenbaum. On the contrary, literary critics and theorists continued to employ the term, and to adapt it for their own, sometimes mutually exclusive, ends. The term has often been skewed to fit the study of a given writer. In order to sort out the competing accounts of the term, we need to isolate the various different contents that have been attributed to it. Having done this, we need to develop the most coherent and productive into an account of the term adequate for a history of $s k a z$ and a description of the poetics of Zoshchenko.

\section{Orality: Oral Speech of a Narrator}

The most common and inclusive definition of $s k a z$ is as an oral narrative. The vagueness of this, Eikhenbaum's first definition of the term, may be attributed to the critic's proximity to the original folkloric meaning of the term and his difficulty in extricating himself from its various associations. In 'Illiuziia skaza' (1918), Eikhenbaum's first article about $s k a z$, he describes a general imbalance in discussions of literature in favour of the written word, and argues that prose should be studied from a phonetic point of view, just as poetry has been studied. ${ }^{3} \mathrm{Skaz}$ is used to illustrate this need, since more than any form of literary prose it bears the traces of the 'living' spoken language and skazitel'stvo, the narrative style of an oral storyteller. These are in fact two separate features of skaz: the incorporation of the spoken language into a literary work is different from the evocation of the feel of an oral narrative, since it is possible to have one without the other. ${ }^{4}$ Clearly, though, the spoken language and the style of an oral narrator can be combined and often are. Eikhenbaum sees no need to distinguish these two elements and presents skaz here as an oral principle, 'nachalo', that asserts a pervading influence over a work. ${ }^{5}$

The same two notions of the narrator and the language are combined elsewhere in Eikhenbaum's treatments of skaz. In 'Kak sdelana "Shinel”' Gogolia' (1919), he 
refers to stories in which the dominant personal tone of the author, i.e. the narrative manner, creates the 'illusion of skaz'. ${ }^{6}$ In the context this seems to mean the illusion that the story is being told by an oral narrator. At the same time Eikhenbaum claims that the basis of Gogol's art is skaz: 'tekst ego slagaetsia iz zhivykh rechevykh predstavlenii i rechevykh emotsii' . ${ }^{7}$ The Formalist critic appears to mean that the stories use the expressive character of oral language to create an illusion of the vivaciousness and immediacy of oral speech. ${ }^{8}$

In 'Leskov i sovremennaia proza' (1925), Eikhenbaum again presents skaz as a 'principle of narrative form'. Although Eikhenbaum here attempts to define skaz in more detail than elsewhere, the notions of the manner of narration and the language employed are again combined:

\section{Под сказом, я разумею такую форму повествовательной прозы, которая в своей лексике, синтаксисе и подборе интонаций обнаруживает установку на устную речь рассказчика. 9}

For Eikhenbaum it is the language the skaz narrator employs that reveals an orientation [ustanovka] towards oral speech. Commentators such as Vinogradov have rejected this formulation as too indistinct and discarded the idea of oral speech or orientation towards it altogether. The notion of skaz as introducing the tone of an oral storyteller has led critics such as N. Rybakov to see it as a variant of folklore. If these ideas are prised apart, then both aspects of Eikhenbaum's account might still be of use. We must first delineate them separately.

The first idea Eikhenbaum is expressing is that the narrator is using the syntax, vocabulary and intonations of oral speech. By this it seems reasonable to understand colloquial speech: language and constructions of a conversational register. With the possible exception of intonation, these can be defined through linguistic analysis. We shall examine this approach to skaz later, with regard to Vinogradov and later Titunik. 
In Eikhenbaum's account, the illusion of oral narration is the effect that the narrator's use of the conversational register creates. However, this simple formulation glosses over the complex question of how this illusion is created. One means is the explicit designation of the situation as oral through the address to and interaction of the narrator with listeners rather than the more distant relation between author and reader. Generally though, this illusion is more a question of narrative manner or literary style rather than of features suited to linguistic definition. For instance, in describing the skaz narrative mode, Eikhenbaum claims that it appears to be improvised and sees it as a return to the 'primitive' form of narration from which written culture had become estranged. ${ }^{10}$ Oral narration in this sense then would appear to be a narration in a spoken and not a textual manner. The illusion of improvisation is not something that can readily be defined through linguistics. This is true of a number of the features of skaz that Eikhenbaum refers to. However, Ong's attempts to define the distinctions between the oral and written modes of communication and narration can help us to decide whether there is any hope of rescuing Eikhenbaum's designation of $s k a z$ as an oral style of narration from the clutches of his own terminology. ${ }^{11}$

One element of skaz that Eikhenbaum stresses throughout these articles is that it appears to be acted out. In 'Kak sdelana "Shinel" Gogolia', he writes of the form's 'verbal mimicry' and 'mimico-articulatory gestures' ${ }^{12}$ He also uses the word 'play' [igra, razygrivanie] in the sense of a theatrical performance. Walter Ong sees the main difference between oral communication and literary communication as the fact that oral speech is a performance, an unrepeatable live event at which both speaker and hearer are present. ${ }^{13}$ The presence of gestures such as pointing is a related feature of oral communication, since the audience are physically present and the speaker can supplement his speech in this way. By contrast, literary presentation has no such dependence on the live interaction of living people and is oriented towards the efficient transmission of already recorded information. Moreover, since the reader is absent at the moment of writing and the writer is absent at the moment of reading, 
there can be no gestures to supplement the words. Though Eikhenbaum only employs the idea of verbal gesture as an image, it can be given a firmer grounding in the linguistic concept of deixis. Titunik defined the use of deixis, or pointing, as a signal of skaz: of the linguistic features that literary discourse normally accepts only in the speech of the characters, but which skaz incorporates into the language of the narrator. ${ }^{14}$

The character of written communication as the transmission of information and oral communication as performance can be illustrated by reference to the novel. As Ong has argued, the novel typifies written culture in its complex climactic plotting and many-sided characters. Such an art is inconceivable without the privileging of information made possible by the written and print forms. Oral narration of all types, including all folklore, is incapable of dispensing information in such a way as to create such intricate plots or rounded characters. Instead, it employs types or flat characters and short or episodic plots. This is because the oral narrative is structured so as to be easily recalled by the storyteller at the moment of performance. In this respect skaz again mimics oral narrative: it has little plotting and rarely has deep or rounded characters. ${ }^{15}$ Eikhenbaum, in this light, seems justified in seeing the novel as the apogee of a literary culture to which skaz stands opposed.

In his analysis of Gogol's 'Shinel', Eikhenbaum argues that skaz's orality is illustrated by certain features of the story's word play which use redundant language deliberately to obscure information. Moreover, if we examine his idea that $s k a z$ creates the illusion that it is being improvised in front of us, one way that such an impression might be produced in a literary work is precisely through the use of redundant language and digressions. In his introduction of the idea of improvisation as typical of skaz in 'Illiuziia skaza', Eikhenbaum argues that written forms force a narrator to choose, fix, and rework. Certainly, one of the main distinctions between the oral and literary forms of narration is the fact that an oral narrator has no opportunity to go back and revise his words since they are immediately made public. With written forms, the words are subject to revision until the moment they are 
released into the public domain. A skaz narrator then, should create the illusion of oral speech by making certain errors, ones that a writer could normally write out. This is all part of the creation of the impression of a live performance, of the immediate presence of a narrator. ${ }^{16}$

The live oral performer deftly uses redundant verbal items and digressions to give himself time to think: 'The ability to correct such mistakes gracefully and make them appear as not mistakes at all is one of the things that separates the expert singers from the bunglers (...) ${ }^{17}$ What distinguishes the skaz narrator from the genuine oral performer is that he tends to be a bungler, particularly in Gogol' and Zoshchenko. In other words, narrating in an oral manner leads him to make a number of mistakes. This is a further indication that a skaz narrator is in fact a literate recreation of the oral state of mind. Oral narration might seem like bungling, or Do-It-Yourself to literate people, but the organisation is in fact complex and has its own rules: 'oral organization is not literate organization put together in make-shift fashion' ${ }^{18}$ Skaz, through its incompetent narrator, tends to differ from folkloric stylisation, where the writer functions more as an ethnographer, recreating an even and efficient narrative through the skilful use of the formulae of folklore. In skaz, the writer tells the story through the mask of an oral narrator who has a poor command of the written language but is unable to organise his tale according to the neat patterns of folklore. ${ }^{19}$

A further example of Eikhenbaum's distorted view of oral cultures is his claim that oral narration is disruptive of tradition and fluid. This is in fact an error. Oral cultures tend to be extremely tradition-bound. They are usually suspicious of change and originality, since without written culture's capacity to keep records they are dependent on easily memorised formulas or clichés for the preservation of knowledge. Eikhenbaum's version of the oral narrator is the fantasy of a literate man, projecting a Modernist poetics upon oral culture.

Yet this exploitation of an image of traditional oral culture by the literate for their own objectives is inherent in the skaz form itself. The paradox of $s k a z$ is that it appears to recreate an oral mindset, and creates the illusion of oral communication, or 
narration, but in fact is a literate person's distorted recreation of oral culture. This paradox has beset reflection about orality from the very beginning. ${ }^{20}$ Skaz is neither fully oral nor fully literary. As we shall see, this is not the only paradox in skaz. However, it is the origin of the ambivalences of skaz.

There are many problems with Eikhenbaum's definition of skaz. A number of commentators have pointed out that Gogol' in 'Shinel'" addresses his reader, as a reader, not as a listener. ${ }^{21}$ This should rule it out as skaz for Eikhenbaum, since it breaks the illusion of oral speech. Moreover, as Vinogradov points out, works where the story is designated as spoken, such as Turgenev's 'Zhid' and Myshkin's story in Dostoevskii's Idiot contain no specifically oral forms of speech. This, he argues, makes it hard to recognise skaz in cases where the story does not explicitly indicate that it is being told by a storyteller to a live audience. Such difficulties lead Vinogradov to condemn the definition of $s k a z$ as oral speech as too vague and he rejects it as the definition of one unknown (skaz) by another (oral speech). Moreover, he argues, it is almost impossible to distinguish oral and written speech in linguistic terms:

почти всякая письменная речь заключает в себе элементы устной, и почти всякая устная, если она не сводится к кратким репликам, содержит формы письменного языка. 22

Furthermore, the spoken language of certain social circles differs little linguistically from the literary language.

Vinogradov attempts to clean up Eikhenbaum's definition of skaz by rejecting the notion of oral speech, and by attempting to make it a form that can be adequately described by linguistics. ${ }^{23}$ To this end he replaces the oral speech definition with the notion that skaz introduces language of a conversational register and conversational intonations. Its particularity is that skaz is a form in which the literary and the conversational intermingle to a greater extent than elsewhere: 'formy skaza otkryvaiut 
shirokuiu dorogu prichudlivym smesheniiam raznykh dialekticheskikh sfer s raznymi zhanrami pis'mennoi rechi' ${ }^{24}$ In pointing to this aspect of $s k a z$ as the combination of literary and extra-literary language, Vinogradov indicated another aspect of its essential ambivalence. Moreover, he attributes these two registers to two planes of narration, an insight that we shall develop with relation to the questions of the narrator and the narrator-author relation.

For Bakhtin too, oral speech is not the distinguishing characteristic of skaz. However, he does not attempt to refute it. Rather, he sees oral speech as a by-product of the primary characteristic of skaz, its orientation towards 'another person's speech' [chuzhaia rech'], i.e. the language of someone other than the author. Bakhtin argues that this other person whose speech is reproduced is usually of low social status, and thus as a consequence (in a country in which most of the population was illiterate) it is oral. ${ }^{25}$ Despite the fact that they disagree with Eikhenbaum's definition of $s k a z$ as orientation towards the oral speech of the narrator, both Vinogradov and Bakhtin retain and reinterpret the term itself, adding further strata of significance. In doing so, they entice the term away from its initial, folkloric context, pulling it increasingly into the literary sphere.

However, the oral and folk associations of the word are powerful and not easily obscured. What is needed is an analysis that understands the nature of the interrelations between the oral and the written modes in skaz. Eikhenbaum does refer fleetingly to $s k a z$ as an example of orality in the written: 'elementy skazitel'stva i zhivoi ustnoi improvizatsii skryvaiutsia $v$ pis'mennosti', but does not follow through the implications of this insight. ${ }^{26}$ Surely if $s k a z$ is the incorporation of elements of oral language into a written form, then the combination of these two principles is significant. Eikhenbaum fails to assess their interaction adequately, and tends to assume that a writer incorporates elements of the spoken form of narration for their own sake. ${ }^{27}$ This is in part because he is unable to integrate his insights into the use of $s k a z$ with those of its narration by a narrator who is also a character. As we shall see, 
the oral mindset and conversational or substandard language are incorporated into $s k a z$ for a variety of different reasons.

The authors of Poetika skaza are amongst the only critics to attempt to develop a definition for the interaction of the oral and written in skaz: 'Skaz - eto pis'mennaia forma, zafiksirovavshaia ustnuiu rech', ${ }^{28}$ Yet the fact that this interaction occurs in writing and not in a spoken form biases the exchange in favour of the written mode. For this reason we can talk of the illusion of skaz. This bias is inevitable, since as Ong has suggested, oral culture cannot reflect upon its own nature. This can only be done in retrospect, by literate culture. ${ }^{29}$ One manifestation of the dominance of the literate mode in this interchange is that in the context of a literate culture, the reproduction of oral language and an oral mindset interacts with the expectation of literary codes. This tends to create a certain distance to the orality represented. This leads the reader to suspect parody, and a joke at the expense of the oral mindset, or at least be aware of such possibilities, since quite clearly the writer is better educated than the oral narrator, and is not using the language that is most natural to him. However, the expectation of parody does not mean that it is universally the case. Indeed, certain critics have assumed that the literate norms serve the oral and folkloric, and that parody is altogether absent from skaz.

\section{Skaz as Folklore}

As we have seen, the word skaz has roots in folklore. It seems that Eikhenbaum chose the word less for its folkloric associations and more for its evocation of the notions of oral speech and a distinct narrator. Nevertheless, he failed to strip the term of these associations, and some subsequent critics have developed this aspect of skaz. We have already examined the notion of oral speech, and in the next section we shall examine the question of the narrator in skaz. However, in this section we shall assess the relation of $s k a z$ to folklore.

Many sources regard skaz solely as a form of folklore. One example of this is the second edition of Bol'shaia sovetskaia entsiklopediia where skaz is defined as a 
genre of folklore: 'ustnyi rasskaz ochevidtsa ili uchastnika o deistvitel'nykh sobytiiakh sovremennosti ili nedavnego proshlogo'. ${ }^{30}$ This, it is claimed, was a form of folklore that was ignored until Soviet times. It was no accident that Soviet folklore scholars took so great an interest in skaz. After the 1934 Congress of Soviet Writers, folklore was promoted for the propagandistic ends of using the authentic voice of the people to condemn the evils of the Tsarist regime and proclaim the advantages of the Soviet order. The folkloric $s k a z$ fulfilled this need particularly well:

Best suited for this purpose were the so-called skazy, biographical narratives and memoirs told by folk-singers and others about their own lives, about the events they had witnessed, and about the remarkable people they had met. ${ }^{31}$

The authoritative Soviet folklorist, Iurii Sokolov, notes the questionable status of such skaz as folklore:

\footnotetext{
Правда, этот повествовательный жанр, или, вернее даже, жанры, стоят в известной мере еще на периферии фольклора; право включения их в состав того, что назьвается фольклором, нехоторыми исследователями еще оспаривается: указьвают на художественность, иные сказы носят характер единичного, случайного фахта, многие из них не переходят из уст в уста, не приобретают устойчивой формы. ${ }^{32}$
}

Sokolov sees their value as documents of the epoch and as eyewitness accounts of history. Whilst they occasionally bear some traces of the influence of folkloric diction, they are not a fixed folkloric form.

Though genuine scholars of folklore such as Sokolov are keen to distance skaz from folklore as such, the argument that all skaz is folkloric deliberately blurs the distinction between genuine folkloric skaz, folkloric stylisation of skaz by a literary author and literary skaz proper (the subject of my investigation). Even the Bol'shaia 
sovetskaia entsiklopediia participates in this distortion by citing Leskov as an author not who wrote literary $s k a z$, but who based some of his stories on peasant $s k a z .{ }^{33}$ This lack of discrimination between literature and folklore appears to have some basis in an influential current of Soviet folklore scholarship:

While Western scholars have emphasised the creative or dynamic role of the individual performer at the moment of performance, they have been careful not to equate the creative process and function of the oral poet with those of the literary poet. Soviet folklorists of the 1930s and 1940s, however, treated the folk performer as a literary artist - a misconception dating back to Rybnikov and Gil'ferding in the nineteenth century and reinforced by folklorists in the twentieth. The role assigned to the new folk poet of the twentieth century was indeed similar to that of the Soviet writer. ${ }^{34}$

There was a widespread blurring of the distinctions between folklore and literature in this period. Pseudo-folkloric works were written in advance and then memorised, or conceived solely for existence on the written page. ${ }^{35}$ It is in this context that certain literary critics have argued that $s k a z$ as a whole is a genre of folklore.

Rybakov is an example of a critic who treats $s k a z$ as a genre of folklore. ${ }^{36} \mathrm{He}$ argues that the particularity of $s k a z$ is that it synthesises elements of folklore and literature. To support this thesis, Rybakov refers to Vinogradov, though as we have seen, Vinogradov points to $s k a z$ as combining literary language with conversational language, not with oral narration or folklore. Rybakov is keen to distinguish skaz as he understands it from first-person narratives serving to characterise the narrator. Skaz is present where a narrative employs the lexis and syntax of folklore, it is 'stilizatsiia pod narodnuiu (inogda arkhaicheskuiu) rech" ${ }^{37} \mathrm{He}$ adds that the narrator of such stories is not the author or a given character but 'narod s ego vekami slozhivshimsia vzgliadom na zhizn', ego otsenkami i "maneroi ponimat' veshchi” (Belinskii) ${ }^{38}$ Where there is an apparently individuated narrator, Rybakov sees this as a purely 
formal device to express the popular voice. Leskov's 'Levsha' is seen as typical of this definition of $s k a z$.

Of the major theoretical treatments of $s k a z$, Rybakov refers to Vinogradov. Though he does not refer to Bakhtin's definition, in Bakhtin's terms, as we shall see, he is referring to stylised skaz. Yet Rybakov seriously underplays the distance between a writer producing a stylisation and the style of the oral narrative that is being stylised. ${ }^{39}$ Furthermore, the possibility that popular language is introduced for parody is not considered for a moment. Instead skaz is a "retransliator" n e p o s r e d s t v en n y k h psikhologicheskikh i mirovozzrencheskikh otkrovenii naroda, ${ }^{40}$ Its roots, he claims, lie in ancient Russian literature.

Rybakov ends his analysis with a reworked definition of skaz:

сюжетноорганизованное литературно-художественное повествование, основанное на устнопоэтических мотивах и образах (сказок, преданий, легенд, устных рассказов, мольбы и т. п.), о необычайных с точки зрения Фактической достоверности и титичных по идейному содержанию событиях из жизни трудовых масс, изображенных на реалистическом, историческом и бытовом фоне с позищий жизненных и эстетических идеалов народа, и выдержанное в особой монологической сказовой манере с ориентацией на традиционную поэтику. ${ }^{41}$

This definition is suited to a sympathetic description of the works of Bazhov, a significant figure for those who argue all skaz is folkloric, but inadequate for description of the work of Babel' or Zoshchenko. ${ }^{42}$ Moreover, Rybakov makes no attempt to distinguish between skaz as a genre of folklore, skaz as folkloric stylisation and literary skaz. An egregious instance of this is the designation of Bazhov as a writer of folkloric skaz when he was in fact literate, a fact that should immediately disqualify anything he wrote as folklore. ${ }^{43}$ This fudging is typical of all the critics who understand $s k a z$ as a folkloric form, since they attempt to play down the fact that 
this is occurring in literature. The divide between the literary and folkloric worlds is deliberately erased so as to link folkloric skaz seamlessly with its stylisation and then to present it as the one true skaz.

Fed' sees $s k a z$ as an organic synthesis of literature and folklore. ${ }^{44}$ He stresses that skaz is 'nedelim ot narodnogo vospriiatiia deistvitel'nosti'. ${ }^{45}$ Its main characteristics are its close links with folkoric tradition, its orientation towards the colloquial language, its system of imagery and its structure. Through these characteristics, Fed' sees $s k a z$ as a stylistically and thematically defined genre. Essentially for Fed', skaz is a skazka (fantastic tale) with a contemporary or realist subject matter:

\section{Одной из важных специфических особенностей литературного сказа является сплав былевого, подлинно жизненного начала с фольклорными истоками - народными преданиями, легендами, сказками, то есть органическое сочетание реального и фантастического. ${ }^{46}$}

What Fed' means by a realist subject matter here is the life of the common people. However, the common people are hypostasised into their Soviet idealisation. This definition enables Fed' to rule out Remizov as misrepresenting the people because his works contain nothing about the class struggle and a lot about popular beliefs and religion.

Fed'stresses that skaz always has a narrator. Like Rybakov, however, Fed'argues that the narrator of skaz fuses with its author and expresses the voice of the people: 'Povestvovatel' - narod - avtor nerastvorimy v skaze'. ${ }^{47}$ This notion of the indistinguishability of narrator and author in skaz expresses an inherent if extreme tendency with the sympathetic reproduction of the voice of the people (what Bakhtin called stylised $s k a z)$. The writer reproducing the style effaces himself before the original style to such a degree that the reader no longer perceives what he is reading as a stylisation. Instead he sees it as a style in its own right, as folklore rather than a reproduction of it. 
Though the authors of Poetika skaza also see skaz as an expression of the voice of the people, they are keen to distinguish between folkloric skaz, folkloric stylisation and the skaz form of literary narration. They state that it is the third form of skaz that interests them in their book. ${ }^{48}$ Critics such as Rybakov and Fed' who claim skaz to be a folkloric form are really interested in one form of it, folkloric stylisation, and denigrate other forms of skaz. Moreover, they conflate the stylisation and the original style, the marginally folkloric genre of skaz. In other words, they attempt to ignore the fact that $s k a z$ as folkloric sylisation, for all its resemblance to folklore, is still stylisation, and that there is necessarily a distance between the person reproducing the style and the style itself. Having erased this distance they censure the skaz form of literary narration for not being folkloric enough, and are incapable of accounting for the parodic use of $s k a z$. As a result they see writers whose use of $s k a z$ has a parodic element simply as bad writers.

\section{The character narrates}

Eikhenbaum's definition of skaz can be broken down into two elements: oral speech and the narrator. Vinogradov interprets the former to mean orientation towards conversational language, but does not develop Eikhenbaum's introduction of the question of the narrator. ${ }^{49}$ Other critics develop the notion of the narrator as a folkloric storyteller. Bakhtin however, develops this aspect of Eikhenbaum's thought in a wholly different direction by elaborating a richly suggestive description of the author-narrator relation in skaz.

In 'Illiuziia skaza' Eikhenbaum praises Leskov highly for the skaz element in his work, referring to two of Leskov's works, Zapechatlennyi angel and Na kraiu sveta. He sees it as characteristic of them that they are told as 'deistvitel'nyi ustnyi rasskaz opredelennykh lits'. Similarly, in 'Leskov i sovremennaia proza', Eikhenbaum adds that skaz 'delaet rasskazchika kak takovogo real'nym personazhem'. The skaz narrator, Eikhenbaum seems to be implying, is a character who is performing the role 
of a narrator. This is a third aspect of skaz that is developed by other critics in a more systematic way.

Bakhtin's redefinition of skaz develops this point further. Skaz is seen as a form of discourse in which the authorial voice recreates the speech of another person [chuzhaia rech], i.e the speech of the characters. However, unlike monological prose where the author's discourse is authoritative and the discourse of the characters simply serves the author's intentions, skaz is double-voiced. This means that the two intentions, that of the author and that of the character, are equal and function like participants in a dialogue. Bakhtin further argues that skaz introduces the voice of a narrator who is not a literary person, and usually from the lower social strata, in particular from 'the people'. ${ }^{50}$ The people [narod] in the Russian context often implies the peasantry, who were overwhelmingly illiterate. Thus the use of oral speech is a spin-off effect of the narrator's social class.

In attempting to flesh out the skeleton of Bakhtin's analysis of $s k a z$, critics have tended to emphasise one or another aspect of it. One group of critics, typified by Titunik, have developed the notion of the narrator whose language displays linguistic features normally found in the speech of characters. The other interpretation, by critics such as the authors of Poetika skaza, stresses the introduction of the language of the people.

In his 1963 doctoral thesis, Titunik takes Bakhtin's categories of the author's speech [avtorskaia rech] and the characters' speech [chuzhaia rech'] and uses linguistics to define their distinctive characteristics. From a wide corpus of examples in Russian literature, Titunik produces a list of the features that distinguish the two types of language, which he names 'Text P' (the characters' speech) and 'Text A' (the author's speech): 
1) Grammatical:
a) first person
b) second person
c) present tense

2) Situational:

deixis

3) Expressive devices

(e.g. exclamations, rhetorical questions)

4) Allocutional devices

(e.g. signalling presence of addressee)

5) Dialectal

a) dialectal and idiolectal deviations

b) marked oral order of speech

6) Semantic:

$$
\text { private point of view in }
$$
a) factual value judgement
b) modal value judgement

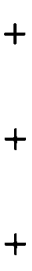

$+$

$+$

$+$

$+$

$+$

(1) 
whereas the discourse of the characters is reported and represented. These two types of discourse are mixed in a number of forms of writing. One example is Free Indirect Discourse (which he refers to by the Bakhtin circle term, 'Quasi-Direct Speech'). Another form where these two types of discourse are mixed is skaz. The particularity of their combination in skaz is that the discourse of the narrator performs certain of the functions of authorial discourse, in particular its function of narrating, representing and reporting, but still has all the linguistic characteristics of the discourse of the characters.

Like Titunik, Vladimir Zakharov sees skaz as making the narrator a character. ${ }^{53}$ Skaz he argues, is an extreme form of the basic tendency of the rasskaz. In Zakharov's account, the rasskaz exists in contrast to the povest', which tends towards the literary language and the systematic relating of facts. ${ }^{54}$ Whereas the rasskaz as such employs colloquial speech, skaz is a narrative that uses oral and alien speech [chuzhaia rech], i.e. the speech normally used by the characters in a novel, in order to create 'rechevaia kharakteristika geroiia'. ${ }^{55}$ On the other hand Zakharov explicitly rejects the definition of $s k a z$ as socially alien speech, i.e. the language of the people. Accordingly, Zakharov disagrees with the definition of skaz put forward by the authors of Poetika skaza, calling that 'narodnyi skaz'. ${ }^{56}$ In part Zakharov does this because he needs $s k a z$ to describe certain works of Dostoevskii, none of which employ the popular language. They do however employ a narrator whose narration differs from the neutral impersonal style of the standard literary narration, the povest', and present a marked and limited point of view distinct from that of the author himself. $^{57}$

Whilst vague, his definition brings Zakharov close to Titunik's view, in seeing skaz as narration by a narrator whose language displays features normally present in the language of the character. However, unlike Zakharov, Titunik does at least admit, as a signal of skaz, 'dialectal deviations', that is elements of speech likely to occur in the language of the people. 
Klawa Nepscha Thresher also sees skaz primarily as narration by a character. She boils definitions of skaz down to three elements: orality, characterisation, and individuation. In producing a workable definition of her own, she argues that all of these can be further reduced to individuation. Skaz, for Thresher, is:

A subjective mode of narration presented with the explicitly individualized voice of a narrator who is perceptibly distinct from the author. The narrator's presence permeates the narration, but he is unself-conscious about his literary function and the forms of his narrative. As he relays his account, the narrator reveals his own values and beliefs, and projects an image of his personality through his opinions, evaluations, and choice of words (...) the language becomes 'pitched' with the distinctive speech mannerisms and specific turns of speech that are characteristic of a certain social or professional group or of a particular individual. ${ }^{58}$

By individuation Thresher ultimately means typification, since the individuality of the narrator tends to be defined through the use of a certain language that typifies the social group to which he belongs. Furthermore, the idea that the narrator is unconscious of his role as a literary narrator, which Thresher introduces to explain away the common designation of the form as oral, seems to me to be unhelpful, particularly since the narrator often seems to be conscious of narrating. The notion of an oral, or at least an extra-literary narrator seems to me to be far more pertinent.

\section{Language of the People}

As we have seen, Bakhtin argued in Problemy tvorchestva Dostoevskogo, that skaz was introduced 'for the sake of another voice, a socially defined voice (...) Strictly speaking, a narrator is introduced, a narrator who is not a literary person and in most cases belongs to the lower strata of society, to the people. ${ }^{59}$ Bakhtin uses the same 
word chuzhoi here as he uses to describe the language of the character. This is one cause of the divergent interpretations of the same passage.

The idea that skaz employs a narrator whose language is that of the people is not incompatible with the notion of skaz as oral. It is an idea that the critics who see skaz as a folkloric form could also employ. The idea was also present in Eikhenbaum's article on Leskov:

для сказовых форм характерно польование устной речњю, имеющей специфические социальые или профессиональные оттенки, - речь крестьянина, полуинтеллитента, мещанина, священниха и т. д. Дело в том, что принщип сказа требует, чтобы речь рассказчика была окрашена не только интонационно-синтаксическими, но и лексическими оттенками: рассказчик должен выступать как обладатель той или иной фразеологии, того или иного словаря, чтобы осуществлена была установка на устное слово. $^{60}$

The strongest expression of the interpretation of $s k a z$ as expressing the voice of the people is to be found in Poetika skaza. The authors of this work stress that skaz is a specifically Russian phenomenon and link it to the concept of narodnost', one of the standard requirements of Socialist Realist art. They see $s k a z$ as a form that incorporates both literary and folk or mass art elements. To this end they refer to: 'chitatel'skoe oshchushchenie, chto za obraznym slovom khudozhnika ugadyvaiutsia sotsial'nye kollektivy, ot imeni kotorykh etot khudozhnik vystupaet'.$^{61}$ Bakhtin is quoted as a basis for this interpretation:

Связав сказовую форму повествования с историко-литературным процессом, с проблемой народности, с демократизацией литературы, М.

М. Бахтин определил как исходные моменты в ее анализе, так и тот путь, по хоторому надо идти даљше. ${ }^{62}$ 
Though also keen to see $s k a z$ as an artistic expression of the people, unlike the critics who see skaz as folkloric, the authors of Poetika skaza distinguish skaz from folkloric stylisation proper which they see as exemplified in the work of Vladimir Dal'. This is in fact a grey area, since skaz too can be a form of folkloric stylisation. Nevertheless, the attempt to separate the two is instructive. These critics argue that whereas, like skaz, folkloric stylisation is a reworking of oral material for literary consumption, it is a very different type of oral material. In folkloric stylisation, the main character personifies folkloric characteristics, his speech is based upon proverbs and other rigid folkloric constructions, whereas skaz uses the raw material of language as it is spoken at the time. Ultimately, in folkloric stylisation, the author and narrator strive to merge completely, and the voice must sound like a 'we'. This need not be the case in skaz.

Poetika skaza also develops Bakhtin's notion of double-directed (parodic) and single-directed (stylised) skaz. ${ }^{63}$ Single-directed $s k a z$ is where the narrator and the author are in sympathy, and double-directed skaz as where the author and narrator are at odds. Viacheslav Shishkov's 'Tatarskii sposob' is seen as as an example of singledirected skaz. Zoshchenko's 'Aristokratka' is seen as an example of double-directed skaz in the distance between the narrator's indignation and the author's ironic attitude to it. Nevertheless, theauthors of Poetika skaza argue that all skaz introduces a narrator who has some distance from the voice of the author. As a result, a voice with ultimate, all-knowing authority is absent from both types of skaz.

This distinction enables the authors of Poetika skaza to highlight the contrasts between $s k a z$ and other related forms. Hence the absence of an authoritative voice distinguishes $s k a z$ from the first person narrative or Ich-Erzählung, in which the narrator recounts the story from a distance of many years. Moreover, whereas in skaz the narrator and author tend to be distinct, in Ich-Erzählung, the narrator and author tend to merge. This is illustrated by reference to Pushkin's Povesti Belkina, in which 
the narrator introduces certain literary references and Latin quotations inconsistent with Belkin's education.

A further respect in which $s k a z$ differs from Ich-Erzählung is that in skaz, unlike in Ich-Erzählung, it is not the individuality of the narrator that is important, but his social type. The narrator is a representative of a group:

\author{
за лишенным индивидуалной характерности рассказчиком всегда \\ угадывается коллектив. Рассказчик выступает в качестве полномочного \\ представителя целой групшы себе подобных: предполагается, что он видит \\ и оценивает охружающий мир тах же, как видят и оценивают его многие, \\ ему подобные. ${ }^{64}$
}

Moreover, the authors of Poetika skaza argue that skaz creates the illusion that it is being told orally, to a live audience, that is either directly addressed or implied in some way. The narrator assumes support or agreement on the part of his audience. This also creates the sense of the narrator as a representative of a collective.

Unfortunately, the notion of skaz which Poetika skaza espouses, namely as a democratic tendency in literature linked with narodnost' ${ }^{\prime}$ is not integrated with its analysis of double-directed skaz. In describing double-directed $s k a z$ and in noting the contrast between the evaluations of the narrator and those of the author, they have described a parodic or ironic form. Surely, if the language of the people is being introduced for a parodic (double-directed) purpose, then the democratisation is illusory or at least not straightforward. The author is at least distancing himself from, if not in fact ridiculing the language or the mindset of the people. This shortcoming is significant. The interplay between the introduction of popular language on one hand and the parodic distance adopted to it is the very nub of the problem of skaz. 


\section{Narration By a Socially Other Character}

Levin achieves a synthesis of these two positions, stressing that the skaz narrator uses the language of a different social class, socially other speech. This for Levin logically follows from the skaz narrator's use of the language of the character, since he argues that this tends to mean the introduction of a narrator who is not an individual character, but a social type. ${ }^{65}$

Levin defines the 'classic' narrative norm as one that uses the language written by and for educated society. This language was defined as the literary norm. This normative form of narration by its very nature is incapable of incorporating those elements of the conversational language that are specific to the oral form of expression. Levin is not very explicit, but we could employ Titunik's list of the features that distinguish the language of the characters from that of the narrator here. ${ }^{66}$ The normative literary narrator cannot use such elements of speech, because his language is generalising and performs the role of representing. The speech of the characters however can. As a result the normative narrator's language sets him above social class and character: 'ego sotsial'naia kharakteristika vystupaet kak nekotoryi normativnyi printsip i ne rasschitana na ego konkretizatsiiu kak lichnosti' ${ }^{67}$

However, Levin attempts to go further than Titunik. He argues that where classic Russian writers of the nineteenth century introduced colloquial speech, many elements of orality, particularly syntactical elements, were deliberately removed.

Skaz as such is the introduction of speech that differs from the narrative norm of the nineteenth century. In particular it is the introduction of socially characteristic language. It is also the creation of the illusion of oral speech through the use of oral speech intonations. In skaz the authorial voice is itself defined, it expresses itself directly, in contrast to the literary norm. By so doing, the authorial voice itself becomes a social type. In other words it becomes a character, and is no longer above the fictional world. It is made a character by its use of a socially marked language as opposed to the unmarked, generalising one. This, according to Levin, distinguishes skaz such as that of Zoshchenko and Leskov from that of Remizov and Bely. With the 
latter, it is not a different social language that interests them, but the enlivening of and transformation of the norm language of the author in prose through the introduction of oral intonations.

Levin's analysis of skaz cleverly combines two tendencies in the interpretation of Bakhtin's definition of the term: on the one hand the idea that the character performs the role of the narrator, a definition given its clearest expression in the work of Titunik, and on the other the idea that it introduces the language of the people. These two definitions need not be in conflict. However they do seem often to have taken different paths.

Natal'ia Kozhevnikova also sees skaz as a striving towards characterisation. ${ }^{68}$ She describes this in Bakhtin's terms of chuzhaia rech' and chuzhaia tochka zreniia. ${ }^{69}$ Kozhevnikova stresses that the Eikhenbaum-Vinogradov definition is not necessarily in contradiction with Bakhtin's. ${ }^{70}$ Moreover, like Levin, she also stresses both parts of Bakhtin's analysis: chuzhaia rech' is the speech of a narrator whose point of view is not the author's and whose evaluations are not those of the author. Though she sees narration by a character who uses 'non-literary' language as 'skaz proper', Kozhevnikova does allow as skaz narratives where the point of view is not that of the author, but which employ the standard literary language. This is Ich-Erzählung in our terms. Moreover, Kozhevnikova argues that the further a narrator's speech is from the literary language, the further the narrator can be assumed to be from the author's sympathies. $^{71}$ Apart from categorising as skaz works that gain nothing from being so identified, such an understanding of skaz is misleading because it demands that we identify an implicit literary norm with the implicit point of view of the author. As we shall see, the author-narrator relation in skaz cannot be assumed to be so simple.

This notion of skaz as being narrated by a character seems extremely fruitful. It is no accident that so many of the more rigorous accounts of the form gravitate towards this definition, since it seems to be the definition that describes the form best. However, if we accept that skaz is a narration performed by a character, or at least by a narrator whose language displays the features typically associated with a character, 
and its main distinctive feature is his use of the language of the people, we are faced with new questions. What is the writer's purpose in introducing such a narrator? Is that language being introduced for its own sake, as a way of democratising the language of literature or for an ulterior, ironic or parodic motive? Is it the language that the author wants or the mentality expressed in that language? The third part of Bakhtin's analysis of skaz initiates discussion of this question.

\section{Skaz as an Ironic System}

Bakhtin defined skaz as a form in which, along with the intention and voice of the author, a second language, chuzhaia rech', and hence a second voice was present. He did not stop there, however, but broke down the interrelation of the author's intention and the character-narrator's language into stylised (single-directed) and parodic (double-directed) forms. ${ }^{72}$ This is a categorisation according to the author's intentions in introducing skaz. With stylised skaz, the intention of the author coincides with that of the style, it is a sympathetic recreation of the given style by an author who sees it as inherently valuable. ${ }^{73}$ Stylisation differs from imitation, according to Bakhtin, by retaining a distance between the writer recreating the style and the style itself: in imitation there is no such distance. In practice though, the two can be hard to distinguish. ${ }^{74}$ As we have seen, a number of analyses of $s k a z$ have assumed all skaz is sympathetic stylisation. However, this is not so: with parodic skaz, the author's intentions are opposite to those of the style itself. The intention therefore is one of unsympathetic exaggeration and parody of the original style. This dual aspect of Bakhtin's analysis has often been ignored or distorted. Many critics have assumed that the skaz narrator was always introduced because the author valued and admired the language of the people. Others have assumed that skaz is intrinsically a form of parody. Bakhtin's achievement in distinguishing these two possibilities needs to be stressed.

An example of one-sided interpretation of Bakhtin's analysis of skaz is Zsuzsa Hetényi. $^{75}$ This critic stresses the socially other nature of the language of skaz, but 
underestimates the role of parody and ironic distance. She quotes Bakhtin's definition of stylisation as if it is the only way in which two voices can be present in one utterance.

A recent example of an interpretation that is based on Bakhtin's analysis of skaz, but ignores the possibility of stylised skaz, is Michael S. Gorham's article on the Rabsel'kor movement:

$s k a z$ is a parodic device that depends precisely on the undermining of narrative authority, mainly by creating discursive distance between narrator and implied author. It does so in part by invoking the speech of the 'other', the 'notauthor' ${ }^{76}$

Natal'ia Kozhevnikova appears to avoid such an imbalance in her account and notes both types of skaz. She expands on Bakhtin's distinction between singledirected (stylised $s k a z$ ) and double-directed (parodic skaz) variants of $s k a z$ by examining the relation of the narrator's evaluations to the author's. In single-directed skaz the narrator's and the author's evaluations and opinions are very close to each other or coincide:

в одном случае слово рассказчика непосредственно направлено на предмет и не подвергается явной экспрессивной переоценке. Оценки автора и рассказчика лежат в одной плоскости или близко соприкасаются. ${ }^{77}$

In double-directed skaz the evaluations of the author and the narrator do not coincide, but are directly at odds. This disparity creates an effect of irony:

\footnotetext{
В другом случае оценки автора и рассказчика лежат в разных плоскостях, не совпадают. Это несовпадение всегда дает иронический эффект. Слово рассказчика смещает контуры объективного мира так, что истиннњй смысл
} 
рассказываемого как бы не совпадает в фокус, не дан непосредственно в рассказе, но угадывается за ним. Художественный эффект основан на двуплановости, на подчеркнутой нетождественности автора и рассказчика, и с точки зрения миропонимания, и с точки зрения его выражения. Лищо автора скрыто, и отношение автора и рассказчика вырастает из того, что и как рассказывает о себе он сам. ${ }^{78}$

Though Bakhtin called this type of skaz parodic, Kozhevnikova is justified in calling it ironic, since she is drawing attention to the contrast in point of view and ways of evaluating rather than contrasts of style and language. This distinction between language and ideological point of view is an important one, and is an amelioration of Bakhtin that will be pertinent to our analysis of $s k a z{ }^{79}$

Her fruitful development of Bakhtin's categories nothwithstanding, Kozhevnikova proceeds to argue that where the language of the narrator is extra-literary, the evaluations of the author and the narrator will not coincide, and where the language of the narrator is literary, the narrator's and the author's evaluations will coincide. Although she does admit that this is not necessarily so, she tends to see any use of a non-standard language as necessarily parodic-ironic. This seems to be a result of the notion of the literary norm that, at least in her earlier articles, she shares with Levin. This position is a serious underestimation of the possibilities for the sincere stylisation of the non-literary language. The fact that she revised it later is probably indicative of its weakness:

Оценки, как же и речъ, соотносятся с «нормалњным» восприятием мира, которое либо присутствует непосредственно в тексте, либо угадывается $а$ ним. Отношение к оценкам, зафиксированным в изображенном слове, колеблется от слияния с ними до иронического отстранения от них, до полного их неприятия - и зависит от степени социальой и 
психологической близости автора к персонажу, от характера самых оценок, от содержания речи. ${ }^{80}$

This formulation is highly nuanced, but still equates a social distance between narrator and author with ideological distance and lack of sympathy. While this may cover the majority of cases, surely it is possible to express one's own views in a language not one's own, and to be ironic in one's own language or dialect. In a situation in which language and social class were undergoing profound changes, it may be very difficult to tell the ironic from the sincere, and social class or language are likely to be untrustworthy indicators of someone's way of thinking.

Though it may be proper to credit Bakhtin for first making a clear distinction between the parodic and stylised forms of skaz, both Eikhenbaum and Vinogradov already perceived that $s k a z$ introduced colloquial or extra-literary language for a variety of different reasons. Eikhenbaum noted that the use of language that deviated from the literary norm often produced a comic effect:

сказ очень часто (но не всегда) имеет комический характер, воспринимаясь на фоне канонизированной литературной речи как ее деформация. Ках речь дефективная, «неправиљная».

Similarly, Vinogradov saw the interactions of two levels in the text as producing the comic effects of skaz. These two levels are those of the reception of the text. The first is the 'subjective' level: the way that skaz pretends that it is received by familiar people of a close circle such as the other inhabitants of Mirgorod in Vechera na khutore bliz Dikan'ki. The second level is the 'objective' sense in which it was really meant for consumption by a completely unknown reader. Vinogradov argues that the discrepancy between these two levels creates comic effects: 'na etom nesootvetstvii, nesovpadenii dvukh ploskostei vospriiatii - zadannoi i dannoi - osnovany ostrye komicheskie effekty'. ${ }^{82}$ Both of these accounts also assume that the discrepancies 
between the fictional situation and the actual situation of the story, or between a substandard usage and the norm are intended solely to have a comic effect. It is misleading to assume this, since disparities may also have a tragic effect, and to do so could lead to us perceiving the comic when a work was not comic in intent. ${ }^{83}$

Léna Szilárd further elaborates Vinogradov's account of the two levels of $s k a z{ }^{84}$ Szilárd sees skaz as an 'exposure and demonstration' of the discrepancy not only between two 'addressers' and two 'addressees', but also between the two corresponding layers of language. Vinogradov's positing of a distinction between the subjective and objective addressers and addressees of skaz serves as the basis for the development of a model which theorises the distinctions between what Szilárd terms the factual and formal encoders and decoders:

\section{FACTUAL ENCODER}

The author and his world-view

objectivated in the work of art

\section{FACTUAL DECODER}

The reader

\section{COMMUNICATION}

hero, event, theme

\section{FORMAL ENCODER}

The narrator

\section{FORMAL DECODER}

The audience of the $s k a z^{85}$

These levels also correspond to the literary or written on one hand and the subcultural or spoken on the other. ${ }^{86}$ The interaction of these two disparate levels is either a 'zealous reproduction of "non-Gutenbergian" linguistic forms', and the factual level effaces itself before the formal, or it is 'grotesque-ironic', and the two levels are in sharp opposition. ${ }^{87}$ The former is typified by writers such as Remizov. The latter is typified by writers such as Zoshchenko and Zamiatin. Szilárd concentrates on the second, grotesque-ironic form of $s k a z$, in which the presence of 
the two distinct levels is most clearly signalled. She argues that the chief means of indicating the distance between the two levels in grotesque-ironic skaz is 'linguistic discrediting', where the narrator uses the language incorrectly, showing himself to be incompetent and untrustworthy as a narrator. Zoshchenko and Zamiatin are seen as typical of such $\operatorname{skaz} .^{88}$

Szilárd's description of the two levels at work in skaz is clear and workable. Moreover, it skilfully incorporates Vinogradov's vision of the intermixing of oral and written codes with an insight drawn from Bakhtin as to the author-narrator relations. However, this development of Vinogradov's analysis of skaz suffers from the same defect as its progenitor, in seeing the linguistic norm as a faithful index of a text's ideological norm, namely the author's intention. Hence it too readily assumes that linguistic incompetence discredits the narrator. It seems that Vinogradov, Szilárd, Kozhevnikova and Levin fall into the trap of trying to find an exclusively textual, linguistic formula for irony and parody. Bakhtin is not guilty of this because he is interested in these forms precisely because they are not linguistically definable, but dependent for their meaning on the context.

As we have seen, a number of critics have been attentive to the parodic or ironic potential in skaz. Generally it seems that a critic stresses either the parodic-ironic or the stylised aspect of $s k a z$, and very rarely both. None of them countenances the possibility of a mixture of motives in a single work. One critic however, A. Bocharov, does express an awareness as to these two contradictory possibilites inherent in the form:

способствуя демократизации литературы, сказ таит в себе и угрозу (не столь уж редко и оправдьгаемую на практике) породить некоторую снисходительость к этому герою с его простыми радостями, назамысловатыми происшествиями, милыми претензиями на значительность своей судьбы. Да и просторечие, которым обычно насыщен сказ, с одной стороны, содействует демократизации, жизнеспособности 
литературного язьгка, а с другой - часто бывает рассчитано лишь на его «экзотизации», необычность. Не оттого ли сказ так часто из средства активизации язька становится средством литературной стилизации?! ${ }^{89}$

Bocharov is using the word stylisation, where here we would use the word parody. He is clearly intolerant of any distance being taken towards the language of the people. It would seem that this is because the people are the agent of universal salvation, and an attitude of parody (or even stylisation) ill befits such an object of veneration. This hostility to the skaz form's inherent possibility of parody and irony, which we have already witnessed in many Soviet critics such as Rybakov and Fed', seems to have hindered investigation into the subject after the 1920 s until the work of Levin, Natal'ia Kozhevnikova and others in the 1970s.

It seems to me that we can further deepen our understanding of the interaction of parodic and stylised skaz by comparing our findings about skaz with more general theoretical treatments of parody and irony.

\section{Skaz, Irony and Parody}

the trembling equipoise between jest and earnest ${ }^{90}$

The terms parody and irony have cropped up in our discussion of skaz without yet being subjected to rigorous analysis. It would seem that parody and irony often seem to compete for the same territory: we found the same phenomenon Bakhtin introduced as parodic skaz referred to as ironic by Natal'ia Kozhevnikova. This is not just a consequence of the terms' shared territory, but also of Bakhtin's vision of language as inextricable from world-view or ideology. Normally parody is said to be the ridicule through imitation of another author, literary style or manner of speech. Bakhtin allows the term for the ridicule through imitation of another's point of view, which would more commonly be termed irony. ${ }^{91}$ Though Bakhtin sees them as combined, and they evidently share common ground, it is possible to differentiate 
them, albeit as contrasting tendencies: parody targets language and style, whereas irony targets mentality and opinions. As Natal'ia Kozhevnikova implied, in relation to $s k a z$, it makes more sense to talk of irony than of parody, because skaz is always by definition a deviation from an author's most natural style, and so is always a form of either parody or stylisation. The point however is which, and whether its target is solely a style or also the opinions of a typical user of that style. Moreover, in Bakhtin's definition, parodic skaz differs from stylised skaz in the author's intention in using it. This reference to authorial intention is a question far more widely discussed in relation to irony than to parody. For these reasons here we examine irony so as to help us understand the uses of skaz.

In Problemy tvorchestva Dostoevskogo, Bakhtin claimed that the parodic form of $s k a z$ was where what the narrator says stands in direct opposition to the author's own evaluation, in other words to what the author gives us to understand. On the face of it this conforms to the most common definition of verbal irony as a form of antiphrasis. This was also known as 'rhetorical irony':

Although in rhetorical irony the intention of the speaker is contrary to what he actually says, rules insure that we actually understand the intended meaning. This irony is based on complete agreement, perfect understanding between speaker and listener, and an absolute notion of truth. ${ }^{92}$

The assumptions required to reach such an understanding are clearly huge and open to question. Wayne C. Booth's attempts to set up firmer guidelines for reconstituting the meaning of ironic utterances are a recent refinement of this view of irony. Booth sees irony as a process whereby the reader rejects one construction, the apparent meaning, and reconstructs a second ironic meaning, though not necessarily the opposite one. This version of irony, which Booth also calls stable irony may be seen as normative, since it contends that we must break down an illusory ambiguity to arrive at a single vision in order to understand a work. ${ }^{93}$ 
From the Romantic period onwards, there has been a tendency to stress the obstacles in the path from the ironic statement to the intended meaning. After all, the meaning is not stated. Irony's most basic operation is to undermine the sense of the surface meaning of a text without offering a clear alternative in its place. It may be an end in itself and if not checked becomes endless subtraction, infinite undermining of meaning. Søren Kierkegaard took a similar view of irony by making it a mode of existence in which the apparent order was questioned, thereby opening the way for belief in a more real, divine order of being. ${ }^{94}$ Both Kierkegaard and Booth demand that we tear down an apparent mask in order to arrive at the final, unified sense. By contrast, Lilian Furst occupies a position significantly different from both the Romantic view (Kierkegaard ) and the rhetorical view (Booth). She argues that even in traditional irony the apparent meaning of what the speaker says and the intended ironic meaning form two alternative or even alternate senses: the intended ironic meaning does not completely cancel out the apparent meaning. This results in a 'double meaning' or 'dual vision':

Traditionally the ironist has a dual vision, for he sees a latent reality divergent from the masking appearance on the surface. While recognising the incongruities of a situation, he seems to accept things at their face value. But at the same time, by one means or another, he lets his other view shimmer through, so that the reader too becomes aware of the alternative. In the reader's agreeing comprehension of the double meaning there is a tacit communication of the ironic perspective from the narrator to the reader. ${ }^{95}$

Furst's account can aid us in our understanding of Bakhtin's concept of skaz as a double-voiced discourse. Bakhtin expresses his vision of the indivisible duality in parody through the image of a dialogue between authorial intention and text: parody is composed of two voices, and cannot be resolved to a single point of view. By classifying parodic skaz as a form of double-directed double-voiced discourse, 
Bakhtin is arguing that there are two voices that converse or compete. Indeed, the very notion of parody is attractive to Bakhtin because it demands two voices: the parodied and parodying voices. These are in a kind of dialogue where the parodying intention does not cancel out the apparent meaning: 'The word becomes the arena for a struggle of two intentions'. 96

Investigations of irony commonly address the problem of recognising something as ironic. This question is of great relevance to that of parodic skaz, since skaz, like irony, adopts a standpoint that is not properly the author's. Booth, who like Bakhtin sees parody and irony as identical, argues that a speaker's departure from his natural style is one indicator of irony: 'If a speaker's style departs notably from whatever the reader considers the normal way for this speaker, the reader may suspect irony'. ${ }^{97}$ Yet this is the case in $s k a z$ universally, whether it is stylised or parodic-ironic skaz, since effectively we know that the author is in fact a literate and a literary person and has deliberately used a language which is not his own most natural style. Skaz creates the mask of a character-narrator through the use of a given style. ${ }^{98}$ Though all skaz creates a verbal mask, only parodic-ironic skaz forces us to see behind it and detect the face of the author, or the intention of the ironist that lies behind this mask in order to understand it. The mask of the person who stylises is not one that needs to be torn away so that we can understand the work. The person who stylises effaces himself before the style. The problem is recognising parodic-ironic skaz.

In attempting to tell parodic-ironic skaz from stylised skaz, the reader must decide how to go about the task. The problem for the reader of skaz is what evidence is admissible is determining whether or not the work is parodic-ironic. Essentially the choice is whether to limit investigation to the text itself or whether to admit, in addition to the text itself, evidence such as the author's statements as to his intention in employing skaz, or his general views as to what is good and what is bad literary style.

Bakhtin and Booth give us grounds to follow the latter path. In Bakhtin's description of parody the author introduces a second intention into the other's style. ${ }^{99}$ 
Parody for Bakhtin is an intentional act of the author. Similarly, in Booth's account of the recognition of irony, he argues that an ironic text demands that the reader make a judgement against the overt proposition, and agree with the author's implied judgements. Essentially this means that we can infer the intention of a work of art, usually deciding not to trust its narrator, and form an image of what he called 'the implied author'. Booth allows the reader to check this against knowledge of the author's views on art and literature. ${ }^{100}$ Booth is confronting a major trend in post-war criticism, the notion of the 'intentional fallacy', which in the Anglo-American tradition was initially formulated as 'the design or intention of the author is neither available nor desirable as a standard for judging the success of a literary work of art'. ${ }^{101}$ This came to be developed in these critics' own work into the notion that intention is irrelevant to the meaning of a text, ${ }^{102}$ and on mainland Europe reached its most spectacular formulation in Roland Barthes' 'The Death of the Author'. ${ }^{103}$ Such approaches demand that we exclude any consideration of or reference to authorial intention. Though excluding references to the author does not rule out extra-textual reference altogether, the disqualification of authorial intention is usually linked to the disbarring of contextual evidence altogether. ${ }^{104}$ This is because the argument is typically posited upon the idea that the text is written in language, a public code in which the meaning of any given usage is not dependent upon any single user such as a writer. Instead we are enjoined to depend entirely on textual evidence for our interpretations.

Yet surely the recognition of irony and parody demands extra-textual evidence, since a sincere or an ironic statement may differ in no semantically discernable way from each other. Meaning here is not textual. Rather, it is the nature of irony that the apparent meaning of the text is belied by its actual meaning. A good example of this is the statement 'What lovely weather' pronounced a) in the middle of a downpour, b) on the first sunny day in Spring, or c) in the middle of the Sahara desert. In each case the statement is the same semantically. Only reference to the context permits us to reconstitute an ironic or a sincere intention. ${ }^{105}$ 
In a recent book about Russian satire, Karen L. Ryan-Hayes pleads for a special dispensation to refer to authorial intent in questions of satire and parody, though she is anxious not to be seen to challenge the 'intentional fallacy' in general:

While we must certainly avoid the so-called intentional fallacy, it seems that satire presents a special case in which it is virtually impossible to proceed without making inferences about authorial intention. The reader must decode the encoded intent and assign what Morson calls 'semantic authority' correctly, i.e. to the second voice. We must understand with whom we are to agree in order for the parody to be effective. ${ }^{106}$

A contemporary philosopher, Colin Lyas, makes a far more forceful case for the relevance of knowledge of the artist's intention as a vital aspect of the context relevant for appreciation of a work of art. Like Ryan-Hayes and Booth, he sees irony as a particularly significant demonstration of this case:

The full and relevant critical description of a text can only be offered with the aid of a knowledge of its surroundings, where this knowledge may include a knowledge of the intention with which it is offered. The clearest case is presented by ironic writings. ${ }^{107}$

Lyas also sees the example of the character-narrator as another good example of his thesis and, like Booth, argues that a distinction between the judgements of the work's narrator and those of its author is necessary to an appreciation of it. ${ }^{108}$ Lyas argues that statements by artists about their intentions may not be reliable, uniquely or even especially authoritative but they are relevant and must restrain the otherwise infinite freedom of the reader to interpret. In order not to become meaningless, our freedom must likewise be circumscribed by reference to the text's manifestation of what the author intended: 
artists show themselves in those works which it is the task of critics to characterize and judge. This fact, in a sense, does indeed put a restriction on the critic. For if critics are properly to characterize works they cannot say whatever they want. ${ }^{109}$

To characterize the work according to the dictates of the elements in it is to say what is true about it. The fact that we must be true to the work does not constitute an illegitimate circumscription of our freedom. How could it? What worthwhile freedom is it that would require us to shut our eyes to the truth about a thing? (...) if my freedom is not improperly circumscribed by a recognition of such elements as words notes and colours, which shape my response to the work, it is not illegitmately circumscribed by the recognition that the elements of the work include qualities that the author displays in it. ${ }^{110}$

In order to discern parodic $s k a z$ (an instance of irony) from stylised $s k a z$, we have to infer the authorial intention, and if necessary employ extra-textual evidence to this end. Booth uses the example of Mark Twain's The Adventures of Huckleberry Finn (which may be broadly considered parodic skaz): 'Mark Twain knew that you would know that he would know his speaker is talking nonsense here. ${ }^{111}$ This is straightforward where there exists a community of values, a sense of a shared but unspoken norm between author and reader. For example, it is easy to see the irony in Swift's A Modest Proposal, because cannibalism is an almost universal taboo. However, in conditions where any stable community of values has collapsed, such as in the aftermath of a revolution, it becomes very difficult to detect irony reliably:

we are often dependent on the assumption that in that time and in that place, this author most probably knew or believed or intended such-and-such, in contrast to what the surface says. ${ }^{112}$ 
Such assumptions might be built on the basis of knowledge of the general tendency of the publication in which the text appears, or on the reputation of the author who signed it. Parody may present similar problems: how can we tell that an author admires or despises a given style, particularly in a period of instability? In this vein, Booth writes of parody:

We can be sure of ourselves only when we have good reason to believe that the author's conception of how to write would exclude his speaker's way of writing. ${ }^{113}$

Yet such indicators are rendered still less reliable where censorship forbids the author from expressing his opinions overtly, as in the case of the so-called Aesopian language. ${ }^{114}$ Moreover, both Booth and Thomson stress that the greater the geographical, ideological or temporal distance between the position of the critic and that of the author of a given work, the greater the possibility of mistakes being made. ${ }^{115}$ Prejudice too can impair the reader's capacity to detect irony, especially if the object of irony is a belief that he holds: a reader who really thought black people inferior to white and slavery justified or justifiable might have missed much of the irony in The Adventures of Huckleberry Finn.

Such considerations surely inform us of the need to work hard to establish the context in which a work of skaz was written, and this context includes the author's intentions where these are available and seem relevant. A significant part of this context permitting us to recognise irony are the specifically written indicators such as the place of publication and the reputation of the author. As Ong has shown, written culture institutes and print culture progressively increases the distance between the writer and the reader: 
After the invention of writing, and much more after the invention of print, the question of who is saying what to whom becomes confusingly and sometimes devastatingly complicated. ${ }^{116}$

This distance enhances the potential for irony immensely: 'The ironic heritage of literacy (...) was strengthened immeasurably in the Renaissance after the appearance of print. ${ }^{, 117}$ By contrast 'oral performance cannot readily achieve the distance from life which complex irony demands. Oral cultures want participation, not questions. ${ }^{, 118}$

In view of this it is not surprising that skaz, a form in which written and oral modes meet, in which written culture reflects upon oral culture, should generally seem to be a structure in which the author, a representative of the written mode of communication, adopts an ironic stance to the often naïve, apparently oral narrator of the story. The comic tradition also tends to make an educated reader expect he can look down upon and laugh at a character and even a narrator employing the popular language. ${ }^{119}$ Yet this need not be the case. In spite of the expectation of irony, in skaz the author can attempt to efface himself and strive towards the simplicity of the oral. The use of skaz may be entirely or overwhelmingly serious in intent. Here we rejoin the question of the distinction between irony and parody, since it is possible for an author to reproduce the language of a different social class, or of someone less educated than himself, but do so sympathetically. The language reproduced may just seem comic to an educated reader on account of its deviations from the standard language, but it may have been reproduced because the author admires it, or a mentality that typically expresses itself in such a language. The distinction between irony and parody is necessary in order to show quite how serious certain uses of skaz can be. The complex interactions of parody and irony in skaz may even be such that we are invited to admire a language but not the mentality of a user, or the other way round.

It now remains for us to examine the interrelation of parody and stylisation, of irony and sincerity, in skaz, building on Bakhtin's insights. 


\section{A Double-Voiced Discourse of Equals}

Hohne's analysis of skaz also uses Bakhtin's interpretation of the term. ${ }^{120}$ One interesting argument that she makes is that although there are two voices present in parody, these two voices are not equal, but instead, one language is used to 'devoice' the other. She cites Zoshchenko as an example of parody in which the two voices are not equal, and his stories present simple moral lessons. Skaz is distinct from parody in her reading:

What is different about the dialect story [skaz] is that there the other's speech acts on and influences the author's intention, a key concept, since in this relationship of author/other, the author is the one with the power. ${ }^{121}$

Though this seems to me to be an inadequate appreciation of Zoshchenko's work, as well as of parody, Hohne is attempting to overcome a shortcoming in Bakhtin's account of $s k a z$, namely that it ignores the possibility of a given example of $s k a z$ being both stylised and parodic. The Russian critic fails to envisage cases where the author has an ambivalent relation, where he is both in and out of sympathy with the narrator or where his sympathies shift. Though Bakhtin discovers such an interaction of a number of equally legitimate standpoints in the polyphonic novels of Dostoevsky and later in the novel in general, in skaz, however, there is either parody or stylisation, and not both.

So as to redress the perceived imbalance, Hohne focuses on the interaction of two languages and furnishes a clear reformulation of Bakhtin's concept of doublevoicedness in relation to skaz:

The skaz author speaks in another person's language, but he does not act as a tape recorder; the other's speech is refracted through the author. Thus, skaz contains 'two semantic intentions, two voices' in one utterance. ${ }^{122}$ 
there is a more or less equal and ongoing clash between the worlds of the author and that of the other, between two sets of ideologies, a clash that results in both sets of words being deformed, changed. ${ }^{123}$

These two sets of views in skaz are the literary and the extra-literary. This clash is also seen as one between the literary and the oral:

There is something like a clash between written and oral, which come together even in the same sentence: there is a real mixing of languages, a clash between them. And the result of this clash is ambiguity. ${ }^{124}$

Hohne argues that skaz assumes a literary reader on the same plane as the author, set against the narrator. ${ }^{125}$ When both author and reader are familiar with the world described in skaz, then it is 'the literature of the people'. Though the terms that she establishes are interesting and could be productive, they soon become reduced in suggestiveness to official and unofficial ideology:

Written and oral language appear in the work and intersect with each other to produce a new meaning. Since we are speaking of literature, these two categories may be designated as literary and extraliterary, but working on the basis of language as ideology, these categories may be broadened to official and unofficial respectively. ${ }^{126}$

The problem with Hohne's interpretation is that ultimately she treats languages in literature simply as discourses of power. Oral and literary, indeed all voices are reduced to their support for or opposition to power. The possibility of ambiguity that she offered is lacking from her own analyses of Babel'. Moreover, Hohne's definiton of $s k a z$ is extremely normative: anything that does not conform to her over- 
ideologised conception of the term is rejected. While this definition may help to account for certain aspects of the explicitly political struggles in Babel"s Konarmiia, it is of little use for the description of most other examples of skaz.

\section{The Relation of Skaz to Other Forms}

Before proceeding to examine the historical manifestations of $s k a z$, we shall here briefly consider the relation of $s k a z$ to other related narrative forms.

Though sometimes narrated by a narrator who is not a character, skaz is very often related by a character-narrator. Sometimes this character-narrator is a participant in the stories, sometimes it is an observer. Where the narrator is a character, skaz is effectively a variant of the Ich-Erzählung. ${ }^{127}$ What distinguishes skaz from IchErzählung is that its language is substandard, that of the people, and not that of the literary norm. Its lack of a distinct linguistic identity tends to result in the narrator in Ich-Erzählung losing his or her distinct identity, and ending up indistinguishable from an impersonal narrator. ${ }^{128}$ Deviation from the literary norm, usually by adopting the language of the people, is the most fundamental characteristic of skaz. It overshadows the question of whether the story is narrated by a character or not, i.e. whether it is personalised or impersonal (overwhelmingly in the first or third person). Indeed, we can see any deviation from the neutral literary norm as being a nascent form of characterisation (Titunik, Levin). Gogol"s garrulous narrator in 'Shinel"' is already half-way to becoming a character and the impersonal narrator of Leskov's 'Levsha' is more than half-way. Hence skaz tends towards narration by a character. The furthest development of skaz is nevertheless its narration by a character-narrator who is a participant in the story he or she narrates. Such a form of skaz is typical of the 1920s short stories of Zoshchenko, and explains why he is so often thought of as the quintessential skaz writer.

This suggests the question as to how far a narration needs to deviate from the norm before it becomes skaz. This is clearly a question of degree and is not a clear-cut matter at all. There are clear cases, where the narrator is clearly not educated and the 
narrator's language is highly colloquial and deviates from the literary norm in almost every respect. The more difficult cases are where the deviations from the literary norm are minimal. There can be no hard and fast rules as to what constitutes skaz and what does not, since the literary language, the conversational language and the popular language are always in flux.

Another borderline case is that of Free Indirect Discourse. This is where the narrator is speaking, but the language is that of a character. Clearly if one character's colloquial idiom dominates the narrator's language throughout the course of a story, or indeed a novel, then this starts to look like skaz, rather than Free Indirect Discourse, which would normally incorporate the language and in particular the perspective of more than one character. Free Indirect Discourse is much freer than $s k a z$, since it does not have to be limited to the language of the people. Nor need it be limited by the consciousness or vocabulary of one character, and never employs a character-narrator. Much of what is called 'ornamentalism' or 'ornamental skaz' is like this: it may be seen as an extremely free type of $s k a z$, or as a restricted variant of Free Indirect Discourse. It differs from skaz in its use of a language that not only differs from the literary norm, but is also too rich and too poeticised to be that of the spoken language of the people. This does not disqualify it from being skaz, but makes it a peculiar and far less restricted type of skaz.

\section{Conclusions}

Though my aim in picking through the competing senses that $s k a z$ has been given was one of clarification, and I deliberately set out to avoid tailoring a definition to suit a given writer, this thesis is at the same time a study of skaz in Zoshchenko's short stories of the 1920s. Consequently, my analysis has at times slewed towards definitions that help to explain his work, and away from definitions that do not. I cannot, for example, accept the definition of skaz solely as folklore, and consider that I have advanced convincing arguments in support of my case, yet one of the reasons that I reject it is that I am unwilling to accept definitions that accord the works of 
Bazhov, the utmost place in the pantheon at the expense of of Babel', Zamiatin and Zoshchenko, whose work is marginalised by the definition of $s k a z$ as folklore.

Moreover, the political imperatives informing such a definition seem to me even more questionable than the threadbare logic that underpins it.

The definitions of skaz that seem both coherent and productive are

i) skaz enacts a confrontation between the literary and oral modes of communication.

ii) skaz is narrated in the popular language rather than the language of the literary norm. This tends to create the illusion that it is being narrated by a character.

iii) skaz is a form that comprises two levels: the oral and popular narrator, and implicit comment upon it by an authorial presence. Whilst it tends towards parody and irony, the author may attempt to efface himself completely so as to create a sincere stylisation.

iv) The interaction between these two levels may be complex. In any given work, the author may alternate between or straddle irony and sincerity. Before setting to work on Mikhail Zoshchenko with the analytical tools fashioned here, we must first examine some of the previous uses of skaz. Consequently, in the next chapter I draw on these insights into skaz for an understanding of its use by Russian writers prior to Zoshchenko. 


\section{Chapter III}

\section{A History of Skaz}

In the previous chapter we saw that skaz can be defined as a form of narration in which the narrator employs a language that deviates from the norm language of literary narration. ${ }^{1}$ Whereas the overriding concern in that chapter was to examine and analyse the various concepts of skaz for their internal coherence, and consequently any reference to individual writers was necessarily in passing, in this chapter I intend to test these theoretical formulations of $s k a z$ against the use of $s k a z$ by a number of writers. In particular, I shall be employing the distinction between parody and stylisation, and attempting to see how well these terms describe the actual practice of skaz by authors prior to Zoshchenko who are mentioned in one or more of the critical accounts of skaz discussed above. At the outset it must be conceded that parody and stylisation can be further subdivided. Among the reasons why a writer might want to stylise the language of the people are an ethnographic interest in that language and mindset, an egalitarian sympathy for the down-trodden, a nationalist identification with one's compatriots, and a love of the raw but poetic beauty of the language of the uneducated. Parodic skaz too may be employed for a myriad of purposes: a writer may want to invite laughter at a way of thinking or writing for political, social, or aesthetic reasons. Such parody may be part of an attempt to encourage a broader epistemological scepticism akin to Romantic irony. The possibility that skaz might be a mask adopted in order to avoid the censors also needs to be explored: the very ambivalence of skaz makes it an attractive, but at the same time a highly inefficient form for the encoding of satirical messages.

In writing this history, I hope to address a common weakness of the more extended accounts of skaz hitherto: they have been intended to describe one writer, and have consequently produced theoretical treatments of the term inadequate for even the briefest of histories of the uses of skaz narration. ${ }^{2}$ Although this is a thesis that 
focuses on Mikhail Zoshchenko's use of $s k a z$, it is also a thesis about skaz, the purpose of which is to bequeath a definition of the term adequate to a description of all its uses. This, it seems to me, can best be achieved by relating its most celebrated instances to one another in a chronological framework. In doing so I aspire not to reassess the various skaz writers, such a project would clearly be beyond the scope of a single chapter, but briefly to suggest avenues for the reassessment of their uses of skaz. In many instances, critics working with rather makeshift definitions of skaz have already perceived the dual possibilities of stylised and parodic skaz at work in a text by dint of the depth of their knowledge of its author, and their native insight. ${ }^{3}$ Where I perceive this to be the case I am only too pleased to recapitulate their analysis or restate it in more rigorous terms.

A further objective of the present chapter is to evaluate the claim that skaz is a deviation from the norm of literary narration. This can be best done by examining, even if briefly, the language of the individual writers who employed skaz. Moreover, in this chapter I propose to explore some of the ramifications of transgression of the literary norm for skaz and skaz writers. In particular, I shall seek to understand to what extent the choice of $s k a z$ narration implies a school of writing, to what extent it gravitates towards a given genre and how far it is possible to make statements about skaz that are applicable throughout different historical contexts. Literary techniques exist in specific historical and critical contexts, and an attempt to relate these questions to skaz entails reference to and a retelling of Russian literary history and some discussion of Russian literary criticism. In so doing I aim to test the claim made by Eikhenbaum and others that $s k a z$ consitutes an alternative narrative tradition to the novel. ${ }^{4}$ To rewrite or reassess Russian literary history in the light of skaz would clearly be a task beyond the scope of this thesis, and it is not my intention to undertake that labour here. Rather, so as to aid the understanding of skaz, I seek to relate $s k a z$ to the major commonly accepted trends in Russian literary history: i.e. to Realism and Symbolism, and to the cultural effects of the Revolution. 


\section{The Literary Norm}

As we saw in Chapter II, skaz was defined in the work of critics such as Titunik and Levin as deviation from the 'unmarked', norm language of literary narration. For Levin and Natal'ia Kozhevnikova, the notion of such a norm is based on the Russian term 'literaturnyi iazyk'. This is a concept of standard Russian that can encompass the spoken language and pronunciation as well as written Russian. ${ }^{6}$ As Levin has argued, in the nineteenth century both the norm language of literary narration and the standard Russian language gravitated towards the language of educated society. ${ }^{7}$ This norm of narration he calls 'klassicheskoe povestvovanie'.

By contrast, skaz, according to Levin, is defined by its deviation from that linguistic and narrative norm. The deviations from the linguistic norm of the standard Russian language that occur most commonly in skaz are 'prostorechie', which may be translated as popular speech, and usages specific to regional dialects. Prostorechie is generally seen as a 'coarse' [grubovatoe] item of the spoken language of the Russian people, and often implies, town-dwellers. In contrast to dialect usages, prostorechie is not limited to the language use of a given region. ${ }^{8}$ These definitions employ the rather loose term familiar from Chapter II: 'narod', the people, and 'narodnyi iazyk', which can also be translated as popular language. As a class, rather than as a nation, the narod may be best defined negatively, as not meaning the gentry. It often seems to imply the peasantry, but does not have to. It can include the merchants, priests, and lower social classes in towns such as the proletariat. Moreover, someone from the narod could learn to speak and write the standard Russian language. Furthermore, educated society itself had many subclasses. Belinskii, for example was a raznochinets. Furthermore, the picture was in constant flux. Throughout the nineteenth century, the standard Russian language was evolving, constantly incorporating elements from other linguistic spheres, including prostorechie and dialect usages. ${ }^{9}$ This evolutionary process was accelerated many times over in the immediate aftermath of the Revolution, when the very notion of a standard language and the definition of it were open to question, as we shall see in Chapter V. However, 
during the 1930 s, literaturnyi iazyk came to mean the standard Russian language, and became a rigidly normative concept employed to underpin the notion of a Realist language. ${ }^{10}$

If skaz deviates from the linguistic norm underpinning 'classical' literary narration of the nineteenth century, as Levin and Titunik argue, then what are the ramifications of this deviation? What is its relation to the cultural forms and traditions that moulded and were moulded by that style of literary narration? That is to say, what is its relation to Realism and to the novel?

\section{Skaz and The Realist Novel}

Russian literature of the nineteenth century was dominated by the Realist novel. Yet there is no work of $s k a z$ that can be unambiguously classified as an example of the novel, and only with considerable critical effort can any example of it be classified as Realist. Skaz appears to represent an alternative current of narrative form to the Realist novel. However, before discussing the relation between the two, I should note that though I consider the term Realism helpful for an understanding of the nature of skaz and of its historical uses, the term is problematic, even in the historical sense in which I employ it, and must be handled with care. To this end, I shall address the question of the specific nuances of Realism in the Russian context. First, I intend to adumbrate the features of skaz that determine its problematic relation to the prescriptions of the Realist novel as such.

The essential contrast between skaz and Realism is one of narrative form. Realism strives to depict and hence depends upon the notions that telling leaves what is told unchanged and that the message or content is more important than its presentation. Indeed the narrative strives towards complete transparency. Christopher Nash, a contemporary critic, describes this well:

It positively invokes the conception that its 'telling' leaves what is told untouched. As a transparent medium (a window, a mirror) it has no qualities 
other than clarity. Since it claims to offer as its 'subject' a reality that is always already there, it disavows the influence of 'form' (discours) upon 'content' (histoire). ${ }^{11}$

Nash argues that there was a deception in this technique:

there is an overwhelming (indeed overweening) deception lodged in the gap between a histoire concerning such characters, for whom existence may be as problematic as you please, and a discours that is as clear cut and reassuring as you could imagine. ${ }^{12}$

In its pursuit of transparency, the Realist novel attempts to avoid drawing attention to the language in which it narrates. Indeed, even discussions of Realism, be they in the Russian or Western contexts, tend deliberately to avoid discussion of the language of narration. To give the appearance of formal transparency, Realism employs a normative, socially and regionally neutral, and therefore unmarked language, shifting all socially and regionally marked language to the speech of characters. ${ }^{13}$ J. P. Stern sees this language as a balance between a completely faithful record of the way in which people speak, which he calls naturalism, and the linguistic creativeness of poetic discourse:

The language of realism needn't of course have the awful flatness of our conversation (...) On the other hand it will have to eschew the linguistic creativeness that is the hallmark of symbolist poetry, of the Joycean stream of consciousness, and the like. The verbal innovations it offers (...) will be infrequent and unobtrusive - realism avails itself of what is given in the broad spectrum of natural language as it avails itself of what is given in experience. ${ }^{14}$ 
By contrast, the $s k a z$ narrator adopts a colloquial, socially and often regionally marked language. ${ }^{15}$ This was not the language of the reading public of prerevolutionary Russia, and as a consequence it tended to draw attention to itself and problematise the narrative rather than simply acting as a vehicle for the story. However, as Stern indicates, the use of such language might also serve the purposes of representation, by meticulously reproducing 'the awful flatness of our conversation'. In other words skaz might also be used to recreate the way people actually speak, because the author values that language. This possibility, that of the stylisation of a socially marked language, has been eschewed by the mainstream of Realist writers in both Russian and Western European contexts. 1 suggest that their reason for doing this was a fear that it should hamper the task of representing an extra-linguistic reality.

In its striving towards transparency, the narrative voice of Realist fiction typically attempts to avoid all personality and partiality. As we have seen in Titunik, these are the traits of the characters, not those of the narrator. Personality in the narrator was seen as part of the Romantic heritage that Realism was attempting to overcome. The Realist text depends on the implicit assumption that:

since among the greatest obstacles to our perception of the truth is the complexity - and inclination toward parti pris — of each individual subjective consciousness and the diversity among the 'subjectivities' that compose human experience taken collectively, the greatest effort must be made towards the ostensibly most 'objective' articulation of the data as possible ('nothing but the truth'), with the minimal visible intervention on the part of the 'teller. ${ }^{16}$

Philippe Hamon's analysis of the features of Realist discourse similarly stresses that in its efforts to present itself as a faithful and transparent record of reality, Realism eschews all reference to the act of storytelling: it 'takes a lot of trouble to 
conceal the place from which it speaks as well as its author's pedagogical status'. ${ }^{17}$ He continues:

Realist Discourse, like pedagogic discourse, will in general reject reference to the process of articulation, and move instead towards a 'transparent' writing dominated only by the transmission of information. This leads to what could be called a neutralization or a detonalisation of the message, that is to say, to a symmetrical absence of participation by author and reader. ${ }^{18}$

The skaz narrator, as we have seen, displays some of the features of a character. At an extreme pole he is a participant in his own story, and incapable of giving a balanced account: he forgets, digresses, concentrates on the peripheral at the expense of the central, and generally shows himself to be untrustworthy. As a consequence, the act of narration itself becomes problematic, and the narrator falls short of the neutral and reliable standard of Realism.

In doing this the skaz narrator sacrifices his claim to be an impartial mediator of the truth. He shows himself instead to be biased, unreliable and open to question. This characteristic of $s k a z$ makes it suited to parodic purposes. Here lies the essential problem of skaz outlined in the previous chapter: is the author adopting the mask of the skaz narrator because he sees that language and mindset as valuable in itself (stylisation), or is he adopting it in order to ridicule it (parody), implicitly demanding that we compare the substandard language and values of the skaz narrator with a linguistic or social norm? As we saw in Chapter II, in order to distinguish between parodic and stylised skaz we must attempt to ascertain the writer's intentions in using skaz. What in his world-view or artistic project attracted the writer to skaz? There are two ways in which we can do this. The first is an analysis of the skaz texts themselves. The second is an analysis of available extra-textual evidence about the writer's own views and the prevailing climate of aesthetic thought. In tracing the use 
of skaz in Dal', Gogol', Leskov, Belyi, Remizov and Zamiatin I intend to use both of these methods, supplementing readings of the texts with extra-textual evidence.

However, before undertaking such an analysis, we must first consider the question of whether or not there is something specific to the definition, understanding or practice of Realism or the novel in the Russian context that would enable it to recuperate $s k a z$ as a part of that tradition. Donald Fanger, for example, has asked whether the distinctive quality of the Russian novel lies in the literary means by which it conveys its messages. This peculiarity would be a formal freedom, in particular in the handling of plot and in the deployment of the 'narrative persona', which he detects both in Evgenii Onegin and in Mertvye dushi. ${ }^{19}$ Fanger certainly seems to have a point, but although the notions of a free 'narrative persona' and a loose plot may describe some of the untrustworthiness of narrators in parodic skaz, they fail to describe the most significant aspect of $s k a z$, and the feature that distinguishes it from Ich-Erzählung and the 'unreliable narrator': its deviation from the norm language of literary narration. Consequently, although it does justice to Gogol's Mertvye dushi, Fanger's is not an account of the Russian novel that can assimilate skaz.

In the Russian context, as elsewhere, accounts of Realism often concentrate on an examination of the work's perceived ideological content or the author's ideology so far as virtually to exclude consideration of a text's form. However, in Russia, this has had unusual and specific consequences: Realism's association with the representation of lower social strata, or with the so-called 'little man' was attributed a lofty moral purpose, in particular the championing of a democratic cause and the criticism of shortcomings in Russian society. These intentions were imputed to Gogol', most influentially by Chernyshevskii. The effect of this was that he was interpreted as an archetypal Realist writer, despite his digressive and disruptive narrative form. Ultimately, this interpretive practice meant that if a critic could find 'realist' intentions in the writer and a corresponding content in his work, then any 
particularities of the narrative, including the narrator's use of substantandard linguistic forms, could be overlooked. However, where such intentions were not in evidence, then the narrator's excessive use of prostorechie would be condemned as an unhelpful or self-indulgent distraction. Through such critical practices, skaz could be accepted as Realist, but only where the author held, or was seen as holding, the requisite political views. Of the writers I shall discuss here, this was the case only with Gogol' . This is indicative of the fact that the difficulties of tracing a Realist or even an 'anti-Realist' tradition in the Russian context centre upon interpretation of Gogol'́ We shall confront these difficulties below, in our discussion of that writer.

\section{Russian Literature in the 1830s}

Russian prose of the 1830 s was in a state of flux, a fertile chaos in which disparate influences competed. The Russian reading public, its cultural institutions, and the Russian literary language, were still in a formative state. Literate society was animatedly debating the questions of national identity and the extent to which the imitation of foreign models was desirable for Russian literature and the Russian language. Realist fiction and the novel had yet to gain the dominant position they were to maintain for the greater part of the century. As most commentators have noted, skaz comes to the fore in periods in which the literary language is undergoing radical change. ${ }^{20}$ It is no surprise, therefore, to see the first uses of skaz in Russian literature coming in the 1830 s, initially in the works of writers such as BestuzhevMarlinskii (1797-1837) and Dal', before before being employed by Gogol'.

\section{Dal'}

Vladimir Dal', like many of the writers who have employed skaz, had a strong interest in ethnography and lexicography. However, none pursued this interest so consistently as Dal' who published a universally acclaimed dictionary of the Russian language, collections of proverbs and articles on the Russian dialects. Dal"s use of skaz is highly folkloric and can be seen as part of his general interest in ethnography. 
Indeed contemporaries called his works 'poeticheskaia etnografiia'. ${ }^{21} \mathrm{His}$ is the most unambiguous case of sympathetic stylisation. We can find ample evidence of Dal"s zealous desire to bring written Russian more in line with the spoken idiom of the people:

По словам В. И. Даля, ему, еще ребенку, всегда хазалось странным, отчего это люди, получившие образование, говорят по-русски не так, как говорят простолюдины. Еще более ему странно было то, что речь простолюдинов с ее своеобразными оборотами всегда почти отличалась краткостью, сжатостью, ясность, определительностью и в ней было гораздо болњше жизни, чем в языке книжном и в языке, которым говорят образованные люди. И он полюбил народную речь.

Dal' wrote:

Еще в корпусе, полусознательно замечал я, что та русская грамматика, по которой учили нас с помощью розог и серебряной табакерки, ни болше ни меньше, ках вздор на вздоре, чепуха на чепухе. Конечно, я тогда не мог еще понимать, что русской грамматики и до сих пор не бывало, что та чепуха, которую зовут «русской грамматикой», составлена на чужой лад, сообразно со всеми Петровскими преобразованиями: неизученный, неисследованный в его законах живой язык взяли да и втиснули в латинские рамки, склеенные немецким клеем. ${ }^{22}$

With both his scientific and literary work, Dal' attempted to redress this imbalance. In 1832 he published his first collection, on the basis of which he has been called a skaz writer: Russkie skazki, iz predaniia narodnogo izustnogo na gramotu grazhdanskuiu perelozhennye, $k$ bytu zhiteiskomu prinorovlennye i pogovorkami khodiachimi razukrashennye kazakom Vladimirom Luganskim: piatok pervyi. ${ }^{23}$ This 
included stories such as 'O Ivane molodom serzhante, udaloi golove, bez rodu, bez plemeni, sprosta bez prozvishcha' and 'Novinka-dikovinka, ili Nevidannoe chudo, neslyshannoe divo'. These were free adaptations of folktales, in other words, folkloric stylisation. They have a personalised narrator who addresses the readers at the beginning of the cycle. As the collection progresses this narrator fades from view. The language of these stories is an idealised folkloric speech. Some years later, Dal' said of this collection:

Не сказки сами по себе были мне важны, а русское слово, которое у нас в тахом загоне, что ему нельзя было показаться в люди без особого предлога и повода - сказка послужила предлогом. Я задал себе задачу познакомить земляков своих сколько-нибудь с народным язьком и говором, которому открывался такой вольнњй разгул и широкий простор в народной сказке. ${ }^{24}$

Dal's 'Russkie skazki' are an example of a borderline case between folkloric stylisation and skaz. The authors of Poetika skaza see Dal"s stories as examples of folkloric stylisation, and certainly the language and imagery of these stories is that of folklore, but, as we have seen, what interested Dal' was the language of the Russian people. He chose the folkloric form, because he could not find any other suitable form.

In the 1840s Dal"s work can be seen as closely related to what was called the Natural School. The aim of the writers that have been loosely associated with this loosely defined school of writing was generally to present man as representative of his social class and environment, and to reproduce his speech accordingly. Dal' produced works such as Denshchik and Peterburgskii dvornik, which are examples of the physiological sketch, the Natural School's most characteristic form. On the whole though, these are not properly skaz, but nearer to Free Indirect Discourse, with the neutral narrator in both stories incorporating more and more of the characters' words into his own voice, and explaining the meaning of the more obscure terms that he 
uses. In this period he also produced stories. A good example is 'Vakh Sidorov Chaikin'. This is the autobiographical story of a character who was an orphan brought up by aristocrats and taught to read and write. It is explicitly presented as written, but the language is not that of the standard written language, and the narrator's position affords the reader an insight into the suffering of the Russian people. Though unambiguously written, the language in which this story is narrated is a strange mixture of written and popular conversational codes that makes it skaz.

Like that of his earlier works, the language of these sketches and stories is rich and interesting, but tends to work to the detriment of their artistic value. Belinskii in particular doubted that Dal' could handle plots. ${ }^{25}$ Indeed, few, even the most sympathetic commentators, such as Mel'nikov and Gogol', are willing to claim that Dal' had a great literary talent. Chernyshevskii in particular was hostile to Dal', and objected to his use of prostorechie as excessive. For Chernyshevskii, Dal"s language hindered the true purpose of stories about the people, in that they disrupted the transmission of information: 'iz ego rasskazov ni na volos ne uznaesh' nichego o russkom narode'. ${ }^{26}$ Soviet critics followed Chernyshevskii's lead and criticised Dal"s verbal exuberance. ${ }^{27}$ As a result, $\mathrm{Dal}^{\prime}$ was seldom published or discussed over the Soviet period. Dal's use of skaz was unacceptable to both Chernyshevskii's and Soviet accounts of Realism.

$\mathrm{Dal}^{\prime}$ appears to be the clearest possible example of stylised skaz narrative. From the evidence of his skaz works themselves, and from the profound and sincere interest in promoting a deeper knowledge of the Russian language to which his literary and academic work attests, it is evident that his intention in writing his skaz stories is never to parody the language or its speakers. ${ }^{28}$ Few of the other practitioners of $s k a z$ present so straightforward a case.

\section{Gogol'}

The discussion of Nikolai Gogol"s work must be central to any consideration of skaz in the context of Russian literary history. His first uses of skaz are the cycle 
Vechera na khutore bliz Dikan'ki (1831). It is in the context of the unstable state of the Russian literary language of the 1830 s that Gogol' produced a style that combined many disparate elements including native Ukrainian folk-art influences, particularly the Cossack ballads [dumy], and the comic style of Laurence Sterne. This combination of native oral and Western written influences runs throughout Gogol"s skaz works. In order to define the style of Gogol"s skaz, I propose to look at the early Vechera na khutore bliz Dikan'ki (hereafter Vechera) and the later 'Shinel'.

There are a number of narrators in Vechera. As Rudyi Pan'ko explains in his preface, he has collected and published the various stories, none of which are told by him. Rudyi's prefaces are the most parodic and comic component in the stories. $\mathrm{He}$ attempts to perform the role of mediator between the world of the storytellers of Dikan'ka and the reading public. He performs this task ineptly, forgetting that he is addressing readers who have never been to Dikan'ka: 'Vot, naprimer, znaete li D'iaka dikan'skoi tserkvi, Fomu Grigor'evicha?' ${ }^{29}$ In the terms established above, in Chapter II, he is so deeply embedded in the oral mindset, where the audience are present in the same place at the same time as the speaker, that he finds it impossible to adapt to the written form, and a readership unfamiliar with Dikan ka. Rudyi's style is colloquial and he is clearly intimidated by the educated panich in a pea-green kaftan who tells stories 'vychurno, da khitro, kak v pechatnykh knizhkakh! ${ }^{30}$ Rudyi's lack of familiarity with the written form is also signalled by his digressions: 'Odnako zh, chto ia $v$ samom dele razboltalsia?' ${ }^{31}$ and his forgetting what he wanted to say (or write): 'Da, vot bylo i pozabyl samoe glavnoe. ${ }^{32}$ In their mixture of oral and written codes, his prefaces are a good example of skaz. The purpose is quite clearly parodic: we are not to understand this narrator's style as one to emulate or admire, and it seems safe to assume that Gogol' could have written a competent, serious preface if he had wanted to. Adopting the mask of Rudyi Pan'ko for the preface serves a purely comic end. He is certainly not a folkloric narrator, nor is he a competent literary narrator or ethnographer. Rather, he is a corrupted, fallen folk narrator; one that is inept because he is neither properly folkloric nor properly literary. ${ }^{33}$ 
None of the other narrators is so clearly individuated as Rudyi Pan'ko. The other two who are identified are Foma Grigor'evich, the clerk of the Dikan 'ka church, and the panich in a pea-green kaftan. Their tales also enact a confrontation between oral and written codes, but in a far less obtrusive manner. Foma Grigor'evich, whom we might assume to be literate given his profession, tells three stories: 'Vecher nakanune Ivana Kupala', 'Propavshaia gramota' and 'Zakoldovannoe mesto'. None of these stories particularly bears the imprint of his personality, although 'Zakoldovannoe mesto' and 'Propavshaia gramota' are both stories about his grandfather, and both are prefaced by conversations where he is asked to tell a story. He tells the stories competently and the focus is more on the supernatural events of the stories than on the narrator's personality. They are stylised $s k a z$, since they are clearly even more lexically and syntactically colloquial than the other stories, and told in substandard language, but not so as to parody or discredit the storyteller. The humour is overwhelmingly situational and not at the expense of the narrator's language. The same is true of 'Vecher nakanune Ivana Kupala', except that here Foma Grigor'evich's story is introduced by another narrator (we assume him to be Rudyi) who tells us that Foma never repeats the same version of a story. Foma tells his story in response to a printed version of it that he objects to, disputing the attribution to him: 'Kto vam skazal, chto eto moi slova? (...) Tak li ia govoril? ${ }^{34}$ It seems that there is something about the printed word that he objects to. This may be its immutable nature, given that he always changes his stories when retelling them.

The introduction to this story also suggests that we have already heard a story from the panich with a pea-green kaftan. Since 'Vecher nakanune Ivana Kupala' is the second story in the collection, this is presumably a reference to 'Sorochinskaia iarmarka'. This story is told in a highly oratorial or lyrical style. It is alone among the stories for exposing the supernatural as based on a misunderstanding. It seems possible to argue that the narrator, who is clearly an outsider at the 'evenings', and eventually turns out to be a commissioner, takes the distance to the supernatural we would expect from a more educated person. ${ }^{35}$ The other story in the collection that 
contains no elements of the supernatural is 'Ivan Fedorovich Shpon'ka i ego tetushka'. This story is said to have been written down for Rudyi Pan'ko by Stepan Ivanovich Kurochka. Here the language is far more standardised and even-flowing than in the rest of the stories, and there are far fewer ukrainianisms. As with the other stories, the narrator is not a character in the story. Some of the humour, however, is at the narrator's expense: for example, he thinks that Ivan Fedorovich has achieved a great deal by becoming a lieutenant after over 20 years' service. In sum, the interplay between oral and literary codes is a constant theme in Vechera, but it is through the mask of Rudyi Pan'ko that this interplay is exploited to particularly comic effect.

Vechera was written at a time when exotic regionalism and gothic horror were made fashionable by Romanticism. Although Gogol' wrote these stories in an attempt to profit from a popular vogue, there is a great deal of evidence as to his genuine interest in folklore and ethnography. ${ }^{36}$ They present a world in which the supernatural permeates the lives of the characters. It is related without any distance from the plausibility of these claims, since the narrators appear themselves to believe in the existence of the stories' spirits and demons. ${ }^{37}$ The absence of parody and resulting lack of distance between the narrator's and author's viewpoints makes Vechera an example of stylised skaz. Moreover, the language, including that of the narrator, is permeated by colloquial and substandard language, particularly Ukrainian influences, but this is not done for humorous effect. Overwhelmingly Gogol' ${ }^{\prime}$ is in sympathy with the language and the world-view of the stories. The language seems to have been introduced for its rich expressive power and vivid colour. The mentality of the characters is also one Gogol' has sympathy with and reproduces so as to create a nostalgic atmosphere of rural idyll consistent with his conservative nationalism. Except in Rudyi Pan'ko, neither the language nor the mentality is being parodied.

There is no doubt that Vechera is an example of skaz. The question remains of its relation to Realism. Chernyshevskii does not accord these stories the pride of place that he assigns "Shinel"' and Mertvye dushi. They seem not to have the ingredients he was to extract from those works in order to proclaim them 'Realist'. However, some 
Soviet critics have been more tenacious than Chernyshevskii. One standard history of Russian literature, though it concedes the 'romantic', 'lyric' and 'subjective' narrative style of the cycle, still manages to term them Realist. ${ }^{38}$ It does this through the skilful manipulation of terms such as "narodnost" and satire, both of which Soviet critics associated with Realism. In particular the term narodnost' is useful here, since it refers to a national and class collective, which, as we have seen, Soviet critics saw as the subject-matter of the Realist method. Thus it is used so as to permit the interpretation of the skaz narration as expressing a content of narodnost':

\section{Основьвая свое повествование не на формах книжного стиля, а на устном «сказе», на живой разговорной речи, Гоголь наиболее полно выражал народный характер самого содержания своих повестей. ${ }^{39}$}

Yet narodnost' is not Realism. If narodnost' were Realism, all works of folklore would be Realist, but they are not termed so even by the most ingenious Soviet critic's most flexible use of the term. We now find ourselves in the territory occupied by Fed' and others in the previous chapter. For such interpretations, the value of $s k a z$ lies in the fact that it is folkloric and therefore partakes of narodnost', and at the same time relates to simple, everyday themes and plots rather than the legendary and heroic subject matter of much folklore. Though this makes skaz doubly acceptable to orthodox Soviet criticism, it still does not make it 'Realist'.

Nevertheless, there is an aspect of skaz that is described by such accounts of Gogol' as a Realist: in stylising, skaz aims at reproducing the language of the people. In other words, it may strive to represent a certain sort of language, and in doing so may be interpreted as rejoining Realism. However, as we have seen, typically Realism is suspicious of verbal exuberance, and does not normally interpret representation to mean to reproducing the speech of the narrator too accurately where this entails deviating from the norm language of narration, since this is normally seen as detracting from the representation of more significant 'realities', termed the work's 
content. Gogol' is a special case, and is granted special leeway because his later work was more plausibly termed Realist. Such allowances were not made for Dal'.

Clearly, the interpretation of Gogol' presents almost as many problems for a history of skaz as it does for histories of Realism. A major reason for this is the vagaries of Russian criticism of the time and the subsequent influence Chernyshevskii. Finally, Gogol”s own evolution and contradictory sensibilities give grounds for a broad spectrum of interpretations. As Vinogradov put it:

творчество Гоголя, впитавшее в себя элементы разнородных, даже диаметральн противоположных литературных традиций и своеобразно их претворившее, могло дать опору разносторонним художественным направлениям. ${ }^{40}$

"Shinel" is a still more egregious example of this problem. The story has a special place in the history of $s k a z$, as a result of its designation as such by Boris Eikhenbaum, in his groundbreaking article. Eikhenbaum's choice of 'Shinel' was quite possibly determined polemically by the fact that in Russian literature the story is more famous for its supposed championing of the cause of the 'little man', and its privileging of content over form. The critics primarily responsible for this interpretation were Chernyshevskii, and to a lesser extent, Belinskii. Chernyshevskii in particular claimed that the sole purpose of every element of narrative form in the story was to evoke sympathy for Akakii Akakievich. ${ }^{41}$ This interpretation established 'Shinel'" as a cornerstone of the Russian Realist tradition. The reinterpretation of Gogol' began at the end of nineteenth century. What interested the Symbolists, and subsequently the Formalists, were precisely those elements of Gogol"s art that Chernyshevskii ignored: Gogol"s extravagant use of language and his deployment of a narrative mask.

However, there are more substantial objections to the definition of 'Shinel" as skaz. A number of commentators have pointed out that it is explicitly a written story, 
and not a spoken one. ${ }^{42}$ Moreover, the narrator is neither a clearly defined character nor is his speech particularly that of the people. However, in its repeated digressions, its garrulous colloquial style and inept narration it does have the feel of an oral narrative. Furthermore, like the narrators of Vechera, the narrator of "Shinel" recounts supernatural events without questioning or distancing himself from them. Nevertheless, it is probably more accurate to see skaz as one element in 'Shinel", as Robert Maguire has done, rather than to see the story as a skaz narrative as such. ${ }^{43}$ Skaz is one means by which Gogol' draws attention to the narrative itself and the narrator at the expense of the story that is being recounted. The skaz elements in the story function parodically, to create humour at the expense of the character and of the narrator. The narrator is less rustic than Rudyi Pan'ko, but no less inept and comic. "Shinel', is parody, but it is not quite parodic skaz.

Gogol' 'is typically seen as riven by conflicts between his didactic aims and his comic gift, between his irony and his lyricism. It is unsurprising then that this brief examination of his use of $s k a z$ finds an analogous dichotomy between the sincere stylisation of the language and mindset of the people and a mocking parody of that mindset and that language in Rudyi Pan'ko. In both cases Gogol"s prose slows the reader down and draws attention to its own style of narration, rather than to the story being related. In doing so he developed in his stories a powerful mine of formal resources for subsequent Russian writers not content with the mainstream of Realist fiction.

Chernyshevskii's interpretation of Gogol' blinded readers to his idiosyncratic style and made him the forerunner of Realist prose fiction. Chernyshevskii encouraged writers to emulate the model of Gogol' rather than Pushkin, by giving precedence to subject matter over style. ${ }^{44}$ This emphasis was a principal feature of the literary Realism that dominated Russian literature in the coming years, from approximately 1855 to 1880 , an era that witnessed the publication of some of the greatest novels of the century. 
In a period dominated by this polemical interpretation of Gogol', it is not surprising that when Dostoevskii made his literary debut, he did it by rewriting 'Shinel'. In fact Dostoevskii's Bednye liudi humanises Gogol’s tale and better fits the image Belinskii had made of Gogol'. Bednye liudi is a novel in letters in which the characters' use of language serves to characterise them. However, though their language is individuated, neither Makar nor Varvara use a substandard, vernacular Russian. This is the pattern with Dostoevskii. His narratives often employ characternarrators to refract information, but always his purposes are psychological and ideological. Though elements of Dostoevskii's work have been interpreted as skaz, the language that the character-narrator uses rarely exceeds the bounds of standard Russian. ${ }^{45}$ Consequently, the language is never an issue in itself, nor is it an explicit indicator of class.

In the period of the flowering of Russian Realism, however, the writers who sought primarily to employ colloquial forms from beyond the standard Russian language were not the famous novelists. The playwright Aleksandr Ostrovskii (182386), and an actor who frequently appeared in his plays, the short story writer Ivan Gorbunov (1831-96), significantly extended the possibilities for the use of the popular language in this period. However, the one outstanding prose writer of this period who employed skaz extensively was Nikolai Leskov.

\section{Leskov}

Leskov began his literary career in the period immediately after the 1861 emancipation of the serfs. Literary and political life of the time was dominated by debates over the question of the Russian peasantry. The most influential intellectual figures of the time in St Petersburg were university-educated aristocrats prone to the idealisation of the peasantry. Leskov was a provincial with a more modest formal education than his literary contemporaries, and was not attracted to such abstractions. Skaz for Leskov was a form in which he could stress his advantages over other writers in his practical knowledge of the Russian people and their language. It also suited his 
need to debunk idealised and abstract representations of the peasants. Moreover, in striving to avoid the novel genre, in which he felt out of depth by comparison with more erudite writers, he needed to find alternative forms. Once adapted to his ends, the skaz short story became his genre.

Leskov was writing at the height of literary Realism. His use of skaz was to adapt it to Realist characterisation. Most of Leskov's skaz stories are frame narratives in which a narrator, sometimes identified as the author, and always someone who uses standard literary Russian, meets a character, who is usually a peasant, and always someone from the people. This character tells their story in their own words, which are not the standard Russian language, but include all sorts of substandard usages, dialectisms, archaisms and so on. This character's story forms the inner part of the frame narrative and dominates the work. Leskov argued that he introduced this unusual language in order to make his characters more true to life: 'my peasants [talk] like peasants, upstarts from their ranks and mountebanks talk a deformed jargon (...) All of my heroes and myself, have our voices. ${ }^{46}$

Zapechatlennyi angel and Ocharovannyi strannik are good examples of this form of skaz. In Zapechatlennyi angel (1873), the story starts with impersonal narration. This sets the scene of travellers taking shelter from a snowstorm and starting up a conversation about guardian angels. This leads to one of the travellers telling a story about having seen a guardian angel. This story is a skaz story in which the narrator, an Old Believer and art-connoisseur, is the main participant. The language that he uses is not standard literary Russian but a richer, more archaic language. Clearly this language is not introduced with a parodic intention, but not solely in order to render the characterisation more effective. It is also employed for its intrinsic beauty. Leskov clearly adored the language of the Russian peasantry for its richly suggestive poetry. In a letter of 1888 , he wrote:

\section{В Орловской и Тульской губерниях, крестъяне говорят удивительно}

образно и метко. Так, например, баба не говорит о муже «он меня любит», а 
говорит «он меня жалеет». Вздумайтесь, и вы увидите, как это полно, нежно, точно и ясно. Муж о приятной жене не говорит, что она ему «понравилась», он говорит «она по всем мыслям пришла». Смотрите опять, какая ясность и полнота. ${ }^{47}$

Indeed, McLean argues that the narrator speaks an idealised language and that the effect of the language itself is arresting:

The archaic, bookish vocabulary and forms make this voice from a cultural past come alive. It is as if the icon itself began to speak. The effect is incantatory, almost hypnotic. It is, to be sure, idealized language, like the person who uses it and the story itself; no nineteenth-century Old-Believer would have spoken so perfectly in character. ${ }^{48}$

We are thus invited to admire the power and charm specific to this language, an emblem of a Russia which is not that of the reader. The narrator is able and trustworthy: he even gives us the option of a naturalistic explanation of the miracle. At the same time the fact that he is the main protagonist in his own story gives it immediacy. Moreover, he knows that his, world is unfamiliar to his listeners, and so he interprets it for them, by, for example, explaining the Old Believers' attitude to icons. In a sense then, he performs the task that Rudyi Pan'ko set himself: that of introducing a world distant from the reading public's normal experience. The difference is that Leskov's narrator is not a comic figure and so does this competently.

Ocharovannyi strannik (1873) is a Leskov story where skaz is used in a similar way. Again the language serves to individuate the portrait of the narrator-character and to give the story the immediacy of oral narration. As in Zapechatlennyi angel, there is something admirable in the narrator's language: here it is its vigour, the energy of an extraordinary life. This is not a parody. However, the narrator's language 
does create some comic effects. An example of this is his description of himself as a 'connoisseur' or 'koneser', by which he means someone who knows about horses 'koni'. This is a 'popular etymology', the misuse or russification of a foreign term. Whilst here this device serves to create a little joke at the narrator's expense, without discrediting him, Leskov was later to employ such devices widely in his skaz stories for parodic purposes.

An example of this is Voitel'nitsa (1866). This story is another frame narration. Here the skaz narrator, Domna Platonovna, is a procuress and a meshchanka who attempts to use the language of the upper classes, but fails. An example of this is her reference to someone being pregnant as 'ona v svoem mar'iazhnom interese'. ${ }^{49}$ The linguistic distortions that litter her speech serve, in the first instance, to characterise her as a meshchanka pretentiously striving to seem refined. They are one of the means by which Leskov parodies Domna Platonovna's desire to present herself as respectable despite the unsavoury reality of her activities.

However, here there is something else at work besides the straightforward Realist characterisation through distinctive language. McLean has pointed to another aspect of this use of language in the story:

Domna Platonovna's speech is thus individualised by specific regional and class features that place her in a geographic and social context, anchor her in a specific linguistic environment. But Leskov goes a step further. Domna Platonovna's idiosyncratic oddities of speech take on an independent aesthetic value, irresistibly attracting attention to themselves. The reader is forced to change the focus of his eye: he no longer merely perceives the characters and the action through the glass of language, but finds himself admiring the patterns and colours of the glass itself. ${ }^{50}$

This 'making stylistic texture an end in itself' was condemned by the Realist critics of the time, whose aim was 'optimum transparency of style'. ${ }^{51}$ As a consequence, 
Leskov's artistic achievement was not appreciated until after his death. Even then there have been many who have seen his language as excessive or gratuitous. ${ }^{52}$

As we have seen, Domna Platonovna's language is parodic, and hence distances the reader from her, alerting him to the unreliability of her account. Once aware that her story is distorted in her telling of it, the reader can separate her interpretation from what actually happened. This creates the two opposing perspectives, or two voices that were earlier said to be characteristic of skaz: we can choose whether to sympathise with her or with her victim. However much we find her actions repellent, Domna Platonovna's worm's eye view of the world seems nearer the truth than the romanticised perspective of her victim. Each perspective corrects shortcomings in the other. This gives the story a certain ambivalence that prefigures Zoshchenko's use of the form.

Leskov was further to exploit the potential ambivalence of parodic skaz in probably his most famous short story: 'Levsha' (1881). This work is narrated by an impersonal narrator whose language is extremely untrustworthy. This is signalled in his reporting of speech: the Tsar is made to speak the same colloquial and popular idiom that the narrator speaks, and by the use of popular etymologies. Examples of these are 'kleveton' for feuilleton, 'melkoskop' for microscope and 'kavril' for quadrille. These strange made-up words function in a number of ways. First of all they serve to characterise the narrator as lacking in education, as someone from the people, and as having a disdainful and badly informed attitude to all things foreign. They are also of intrinsic value as humour, in part because they have a certain truth, and make us see things in a different way: a feuilleton may well be an article full of calumnies [klevety], and a quadrille could be a dance upon a carpet [kover].

Though they characterise the narrator and express a certain truth, the function of these popular etymologies is parodic. They distance the author and reader from the narrator's unreliable language and consequently from his views. Warned by these distortions, the reader can adopt a different attitude to the events of the story from that taken by the narrator. Where the narrator approves of Platov, his violence towards 
subordinates and his xenophobic, aggressive patriotism, the reader can see a parody at work, and discern a quite different attitude on the part of the author. This reading of the story is encouraged by the plot, in which the English appreciate the left-handed craftsman's talents more than the Russians do. Reading in this way we see two mutually contradictory perspectives at work in the story, the explicit parodied views of the narrator, and the implicit parodying consciousness of the author. In other words, Leskov employs a garrulous narrator to create what Bakhtin calls 'doubledirected discourse'. This of course depends on the narrator describing an experience or imparting information that contradicts his own interpretation of that experience or information. In doing this, 'Levsha' exploits the inherent duality of skaz for satirical ends. An anonymous reviewer of the time picked up on this:

The entire tale appears to support Mr. Aksakov's theory about the supernatural capacities of our people, who have no need of Western civilization; but at the same time it contains within it a very sharp and malicious satire of that very theory. $^{53}$

Unfortunately, few critics understood the work so subtly. There was a huge misunderstanding when the work was first published with a framing prologue in which Leskov claimed that he copied the story down from the words of an old armourer from Tula, whom he met in Sestroretsk. ${ }^{54}$ Critics took Leskov at his word, and mistook the parody for a real oral legend. At the same time he was condemned or praised for the narrator's views, in particular his xenophobic nationalism. McLean has highlighted this contradiction:

Readers who thought the story a pure transcription of folklore could not acknowledge the double perspective, though they still inconsistently ascribed to Leskov views expressed in the story of which they disapproved. Thus the 
problem of the story's origin became integrally bound up with the question of moral interpretation. ${ }^{55}$

The danger that readers fail to appreciate the 'double perspective' is a problem that seems to dog works of skaz, reaching particular intensity in the case of Zoshchenko. However, Leskov is partly responsible for the critical confusion. The work camouflages its message well, since we know that parody is at work, but we cannot be entirely sure how far the parody goes. McLean relies on biographical and extratextual data for his interpretation of the work as an expression of the author's despair at the state of Russian society, which was presented in an oblique form so as to avoid censorship. ${ }^{56}$ McLean accepts that it failed to make its point, and in writing of another skaz story by Leskov, Polunoshchniki, he argues that it is a 'serious technical difficulty of the skaz' that readers may not interpret the story as the author intended. ${ }^{57}$ It would seem that $s k a z$ is not well-suited to the making of such polemical points, because there is too great a danger that the underlying message will not be perceived. $S k a z$, in other words, makes the already difficult task of discerning the author's intention in a work harder still, yet more important than ever.

In this light, it seems possible to see the choice of parodic skaz in 'Levsha' as motivated by Leskov's deep ambivalence towards his country, an attitude that McLean has characterised as 'a violent oscillation of the emotional pendulum between love and exasperation or despair' ${ }^{58}$ There is something endearing about the language and even many of the attitudes of the narrator: his intolerance of the Tsar's infatuation with all things foreign is not wholly unjustified. Unlike Gogol', the parody here is social, and for a satirical purpose: what absurdity there is not part of the essential nature of things, but an absurd way of doing things that could be changed.

Leskov developed skaz immensely, producing in 'Levsha' a highly ambivalent form combining parody and stylisation, the two inherent possibilities of skaz narration. It is Leskov's most challenging use of the form. At the same time, the stylised skaz of his frame narratives present examples of the rich possibilities of the 
spoken language of the common Russian people. Whilst Leskov in these stories adapts skaz in part to the demands of Realist fiction, at the same time, in the highly colourful language of his narrators, he exceeds the boundaries of what was acceptable in Realist form, by problematising the process of representation. This was not appreciated by critics of the time, but made him extremely attractive to Symbolist writers looking for a native Russian prose tradition free from the strictures of Realism.

\section{Skaz and Modernism}

The skaz form reached its apogee in the period from 1905 to 1925. This is also the modernist period. There are a number of aspects of the skaz form that made it attractive to writers of that era. The most salient of these are its undermining of stable narrative authority and consequent problematisation of the process of representation, the privileged status it accords language over and above narrative itself, and its compatibility with parody and an ironic stance. In these ways the formal properties of skaz suited a number of the major concerns of modernist writers.

Modernism is invariably described as an art of crisis, an art that responds to a historical and cultural crisis perceived from the late $1890 \mathrm{~s}^{59}$ Thought in general in this period shared the feeling that something fundamental had changed, and a general sense of instability. Science had offered certainty in the nineteenth century, but now it too had become a source of radical scepticism. In particular Einstein's theory of relativity argued that no law or observation can be universally reliable, but depends on the position of the individual observer. This profound sense of upheaval entailed a questioning of the means by which reality was apprehended and tended towards a rejection of 'the positivistic mode of cognition that relied on the surface reality of empirical facts subject to Realistic representation' ${ }^{60}$ It had wide-ranging effects on the very form of artistic expression. It was: 
the result of and the reaction to a crisis of authority which affected every sphere of activity in Western Europe and America in the late nineteenth century political, philosophical, scientific and artistic. At the artistic level this was a crisis of confidence in the authority of the author or creator. Where the Romantic poet had been convinced of the truth and value of what he had to say, his modern counterpart could only see the absurdity of such a posture. ${ }^{61}$

This radical questioning of the processes of representation tended to mean a rejection of the idea that the language of narration could be transparent and a problematising of the status of the author and his authority. One of the ways in which skaz was useful as a narrative method suited to the new sensibility was that it refracted reality through the point of view of an observer-character, or even a character-participant. In so doing it narrated in a more palpable way than had previously been done. Natal 'ia Kozhevnikova noted that the history of narrative form in the nineteenth century was the gradual side-lining of the author's subjectivity and the increasing dominance of the point of view of the character. ${ }^{62}$ This tendency became more marked as the century drew to a close. Chekhov is illustrative of this, in that his so-called 'objective' technique, from around 1886, is one of Free Indirect Discourse in which the authorial voice is dominated by the language and perspective of the character. ${ }^{63}$ Skaz develops to an extreme this tendency for the author to leave perception and ultimately narration to the characters.

Another consequence of this new sensibility was the widespread abandonment of the attempt to mediate reality through a language that aspired towards the condition of transparency. Stern sees Modernism's exaggeratedly self-conscious use of language as one of the ways in which it upsets Realism's balance. He attributes this directly to Modernism's crisis-conscious sense of meaninglessness:

Finding nothing significant to retrace, literature is now faced with the novel task of having to create meanings, as it were ex nihilo. It turns away from realism to 
writings determined by other kinds of balance. The documentary, the literatures of solipsism, of symbolism, and of language consciousness are alternatives in which the elements of world, self, meaning, and language respectively assume dominant, value-creating roles. ${ }^{64}$

One aspect of Modernism's heightened language consciousness was its use of parody. ${ }^{65}$ As a two-planed discourse of language about language, parody draws attention to language and further serves to question the notion of a transparent medium in the process of representation. Skaz too, as a use of language that draws attention to itself, was also attractive to modernist writers. Szilárd sees the attraction of $s k a z$, and the related form of ornamentalism, as part of a general striving in European Modernism to:

трансформировать романную прозу за счет функционального преобладания слова над цепью событий и раскрывающимися в них персонажами. ${ }^{66}$

Similarly, Patricia Carden sees ornamentalism as synonymous with Modernism in Russian prose. ${ }^{67}$ This claim needs to be tested against a more careful consideration of modernist currents in Russian literature.

\section{Skaz and Symbolism}

The initial current of Russian Modernism was Symbolism. In the movement's final stages, in the aftermath of the 1905-07 Revolution, the Russian Symbolists moved away from exclusively lyric forms, and became interested in forms capable of exploring questions of history, Russia and the people. For some this meant a turn from poetry to prose. There was nevertheless an enduring hostility to the Realist novel. The quest for a language-conscious prose form adaptable to the Symbolists' poetic vision unearthed Gogol' ${ }^{\prime}$ and Leskov, the tradition of $s k a z$ that had been obscured and marginalised by Realism. 
Z. G. Mints has analysed a shift in Russian Symbolism's attitude towards myth. Prior to the 1905 Revolution, the Symbolists were concerned with myth in Christian or Western demonology, and myth in Western and Russian literature. Moreover, they were interested in the myths themselves as expressions of a metaphysical truth. After the 1905 Revolution they turned their attention to Russian and Slavonic pagan folklore. Their attitude to these myths was quite different. They now sought truth not in the myths themselves, but in the popular, archaic or national world-view reflected in the myths. ${ }^{68}$ This interest coincided with a general boom in folklore scholarship from the late nineteenth century, and increasingly rapid industrialisation that worked to undermine the traditional societies that underpin folklore.

Skaz enabled the Symbolists to explore folklore, the popular mentality, and popular speech, whilst retaining the freedom to experiment that might be sacrificed in more rigorous forms of folkloric stylisation. Aleksei Remizov made the most extensive use of $s k a z$ in this period, but Andrei Belyi was first to employ it.

\section{Belyi}

Before turning to $s k a z$, Belyi attempted to create an innovative prose form closer to music in his Symphonies. These works attempted to disrupt the normal continuity of narrative time and space in order to suggest a reality beyond these dimensions. In 1909 Belyi published Serebrianyi golub'. This work was part of his response to the Symbolist crisis referred to above. Whereas in his previous work Belyi had assumed that art would impart a mystical experience that would transform each individual reader, the exploration of the problem of forming a transformative community led Belyi towards skaz and ultimately towards the novel. The prose model that Belyi attempted to adapt to his purposes was that of Gogol', about whom he had written a work of literary criticism earlier that year.

In Serebrianyi golub', skaz is one element of the narration and is linked with the the village of Tselebeevo and the religious community of the Doves. Other elements, such as the life of the aristocrats, are narrated in a more neutral, standard Russian. 
Thus the narrative manner changes in accordance with what is being depicted. The skaz part of the narration is not fully personalised, but a disembodied 'we', a kind of voice of the countryside and the village. The language is a highly stylised version of peasant speech, tending towards the ornamental in its inclusion of many literary expressions as well as more colloquial and popular usages. When nature is described in this voice it is often made animate, and the uncritical reporting of rumour is reminiscent of Gogol"s 'Shinel'.

Such devices are all part of the stylisation of peasant speech used to create a certain atmosphere, a generalised image of the Russian countryside, in which the miraculous is still possible. The skaz element of the story has something of Rudyi Pan ko's introduction: it includes digressions and apparently irrelevant information. Moreover, like Rudyi, it forgets that it is written and invites us to ask the priest's wife if we do not believe that Tselebeevo is a wonderful town. ${ }^{69}$ Yet the overall purpose of this style is not comic. Instead it appears to be a sincere stylisation of the oral speech of a peasant: the narrator's language and mentality are not being parodied. However, since the skaz narrator is not the only voice in the story, but one of a number, it is clearly not being presented as an authoritative way of seeing the world, not invested with ultimate semantic authority. Instead, we arrive at the truth of what is occurring by piecing together information gleaned from the various voices, none of which is completely trustworthy. Belyi seems to be attracted to skaz both for the evocation of a certain mentality, and because its untrustworthy narration suggests that the ultimate truth is inaccessible. Belyi's use of skaz undermines narrative authority after the manner of parodic skaz, but for purposes more typically associated with sincere stylisation.

Nevertheless, skaz was not central to Andrei Belyi's literary work: only this one element in one of his prose works can be called skaz. The most significant use of skaz by a Symbolist was in the work of Belyi's contemporary, Aleksei Remizov. 


\section{Remizov}

Aleksei Remizov's whole fictional work is permeated with the use of a form of skaz. This appears to be part of project to russify the Russian language in an attempt to gain access to a more essential, primitive consciousness marginalised by the rationalised, europeanised, standard written language. His explicitly formulated artistic project and world-view are intimately bound up with his use of skaz.

Remizov's skaz is most definitely stylised; he is never parodying the language of his narrator, and not suggesting that we compare it with the standard Russian language. Remizov wanted to make the literary language more dynamic, to introduce 'chat' [viakan'e] into it:

\section{Надо разрубить, встряхнуть, перевести на живую речь - выговаривая слова всем голосом и заменяя книжное разговорным. Иначе бесцветные фразы, не светящиеся слова и коротышка мысль. ${ }^{70}$}

This was an extremely conscious project with Remizov, and he named Dal', Gogol' and Leskov the writers who had succeeded in making the Russian literary language talk, and whom he wanted to emulate.

There are no frame narratives in Remizov, nor is the skaz narrator in Remizov personalised, indeed the language is infinitely more complex and more musical than the language of any really existing person's colloquial speech. ${ }^{71}$ Indeed, Remizov is difficult to read, even for the educated. Often the voice of the narrator and that of the character intermingle in forms of Free Indirect Speech. Moreover, the narrator habitually sees nature as animate, so that the boundaries between man, nature and thing are also blurred. Language itself seems to be more a fact of nature than a manmade object. Where Realism placed man at the centre of the world through its rational causality, individuated characters and strong psychological motivation, Remizov uses skaz to suggest that life has an ungovernably tragic course and man has no more power over it than inanimate objects do. This narrator ultimately appears not to be a 
human voice, but the voice of life itself. At the same time there seems to be a tension between the rich and beautiful expressive power of his language, and the gloomy vision of the world it articulates:

As with other writers of the Silver Age, Remizov's primitivism was one of the manifestations of twentieth-century anti-rationalism. By exploring the child's and the primitive's sensibility, Remizov was able to challenge rational cause-and-effect relations and present a view of the world as illogical, inexplicable, and ungovernable. He was also attracted to primitivism because he valued its poetic and imaginative qualities. ${ }^{72}$

Greta Slobin sees in Remizov a belief in the regenerative power of language that counterbalances his tragic view of existence. ${ }^{73}$ Certain stories certainly counterpose the language and the world. This tension is thematically explored, for instance in Tsarevna Mymra (1908), which dramatises the fall from a rural childhood accessible in dreams into the betrayals and corruption of the urban and adult world. Yet there is scant evidence of language's regenerative power in Remizov's work. Most of Remizov's other works, despite their stylisation of the folkloric world, do not suggest that it is more innocent or pure. The cycle of evil is already present in the traditional, folkloric world of Zanofa (1907), where a woman is accused of being a witch and murdered on the strength of rumour. This vision of the world is unrelenting. In works like Pozhar (1906), Petushok (1911) and Krestovye sestry (1910), Remizov suggests that neither social revolution and technical progress, nor the pursuit of love and personal advancement will redeem either the individual or the world from this cycle of evil. His rejection of linear progression in favour of cyclical plots, and the repetition of motif are further expressions of his hostility to the notion that time progresses for the better. Remizov may be called a primitivist, but this is not because he believes the primitive world-view to be more innocent or pure. Rather he believes 
it to be free from illusions as to the powerless and inherently evil nature of man, summarised by the refrain from Krestovye sestry: 'Chelovek cheloveku brevno'. ${ }^{74}$

Remizov's work belongs to a period in which Symbolism, as we have seen, retreated from its more ambitious claims as to the transformative power of art. Symbolists initially sought to challenge and disrupt the reader's expectations of temporal and spatial continuity so as to suggest a higher reality. Remizov disrupts the expectation of Realist narrative form and transparent narrative discourse, but suggests no higher reality. This development of Symbolism was to be further developed by his successors such as Shmelev (1873-1950), and in particular Zamiatin, into what was called 'Neo-Realism'. 75

\section{Zamiatin}

In his 1922 essay 'O sintetizme’, Evgenii Zamiatin described his prose as NeoRealism, a synthesis of Realism's everyday subject matter with Symbolism's distance from the world. ${ }^{76}$ Whereas in Symbolism this distance was the result of a belief in a higher reality, Neo-Realism's distance was characterised by irony. This was a subtractive generalised irony towards the value of apparent reality, motivated primarily by an awareness of the instability of a world subject to abrupt and bewildering technological and social change. Zamiatin found Remizov's skaz style readily adaptable to this purpose.

In the initial period of his literary career, from his literary debut in 1908 to 1917, Zamiatin's work was dominated by skaz. Paradoxically, given his world-view, Zamiatin uses skaz in these works, not to represent a world racked by change, but one of stasis and stagnation that resists all change. Typical of this is Uezdnoe (1912). In this work, Zamiatin employs the impersonal but colloquial narration of a member of the provincial town. The voice of this insider, sympathetic to the values of this community, dominates the narration and suggests the closed circle of a corrupt society hostile to dissent and change. The story's episodic structure, a common feature in $s k a z$, also de-emphasises action and adds to the atmosphere of stagnation. 
Zamiatin, like Remizov, exploits the power of skaz to portray an unbroken cycle of evil. However, from the philosophical purposes of Remizov he turns it to more sociopolitical purposes, in which the vicious circle might be broken by an act of revolt or moral courage, but is not. Zamiatin is not interested in the genesis of evil, but in the question of revolt. In this sense, Uezdnoe is the tragedy of an outsider, a potential rebel, who is all too easily reintegrated into the routine and corruption of the community.

As with Remizov, Zamiatin's narrator has a rich vocabulary, access to the characters' inner thoughts which are often rendered in Free Indirect Speech and he occasionally uses literary devices such as images and repetitions. But whereas with Remizov such motifs work to reinforce his unremitting vision of inescapable evil, the images in Zamiatin at times suggest an authorial comment on this world. A good example is the image of the 'kamennaia baba' at the end of the story, which suggests the complete dehumanisation of Baryba, the main character. This image is revealing as to a further contrast between the two writers: Zamiatin uses this image of primitive art as an emblem of a stasis that can implicitly be broken.

Zamiatin also uses directly parodic skaz. The narrator inadvertently exposes the society's attitude to religion whilst apparently taking a sympathetic view of it: 'prikhozhanka ona byla primernaia, bogoboiaznennaia, khorosho platila'. 77 The narrator's small town distaste at political events occurring elsewhere in Russia and for newspaper reports of them is also satirised in the context of the story:

как газеты почитать - с ума сходят. Почесть, сколько вехов жили, Бога боялись, царя чтили. А тут - как псы с цепи сорвались, прости Господи (...) а у нас пустяками этими разными и некогда заниматься. ${ }^{78}$

However, Zamiatin cannot be taken as implying that the neutral, standardised Russian language is more trustworthy than that of his narrator. The representatives of the metropolitan world in Uezdnoe are every bit as repugnant as the provincials. As 
Alex Shane has argued, despite his negative attitude to the provincial world of Uezdnoe, Zamiatin does seem to be attracted to the expressive power of its language: 'the provinces provided him with numerous colloquial and regional expressions to use in renovating the literary language'. ${ }^{79}$ It could be added that the elliptical syntax of the oral narrator is also attractive to him, as can be seen in his later fictional works and essays. $^{80}$

Zamiatin then in this work, and throughout the skaz work of this earlier period, creates a strange mixture between the stylisation of the language of this provincial world, the expressive power of which he admires, and the satire of its mentality as vitiated, venal and vegetative. In other words, both sympathetic stylisation and parody are at work in Zamiatin's use of skaz, even in the same work.

With each of these three writers who employ ornamental skaz, there is a use of skaz to suggest the powerlessness of man, and his lack of control over his language. The impersonal, but highly stylised language of the narrator is used to imply that it is not man, but nature talking, and that the human being is at the mercy of an indifferent environment opposed to change, and which is far more likely to change him. Although both Remizov and Zamiatin use ornamental skaz to create this all-pervasive linguistic environment, for Remizov, man's helplessness before this environment is an atemporal existential condition, for Zamiatin, his lack of power is the result of the wrong way of organising society. In Chapter IV I shall discuss Zoshchenko's use of the technique of ornamental skaz which he inherited from these writers, and in Chapter VI I aim to examine the extent to which Zoshchenko is able to use his predominantly narrator-participant $s k a z$ so as to suggest a predicament in which language rebels against its user with tragi-comic results.

\section{Skaz after October}

It is the dominance of $s k a z$, and the related form of ornamentalism, in the $1920 \mathrm{~s}$ that particularly concerns us. ${ }^{81}$ As one critic said at the time: 'Tiagotenie k skazu 
iavliaetsia obshchei chertoi sovremennoi prozy. ${ }^{, 82}$ Skaz was also first defined and discussed by literary critics in this period, as we have seen. The question we must answer is precisely what aspect of skaz attracted writers in the early 1920 s and to what purposes they put it. In seeking a response, I shall also examine the major $s k a z$ theorists' accounts of this dominance, where they have discussed this question.

While, as we have seen in the more general discussion of Modernism, it was not only in Soviet Russia that forms such as skaz became attractive at this time, most Soviet critics have seen the widespread use of $s k a z$ in this period as a particularly Soviet phenomenon, a reflection of the increased power of the workers and peasants. Rybakov, for example, argues that writers from the peasants and soldiers, having been through the war, and knowing not only the people's language but also their way of thinking, turned to skaz in order to make known the events of the people's life, the Revolution and the Civil War, in their own language and through their own eyes. ${ }^{83}$ The problem with this view is that it assumes skaz either to be literary expression of the people by the people, or when the writer was, like Zoshchenko, from an intelligentsia background, to be a self-effacing stylisation. The possibilities of a double-voiced skaz, which uses the language of the people, but takes a certain distance to it, are ignored.

Natal'ia Kozhevnikova also argues that writers turned to skaz in the 1920s as an attempt to represent the profound social changes that had occurred. ${ }^{84}$ Writers chose a narrator who would refract the new situation through both the language and mindset of a given social group. Implicitly the chosen social group would be the peasantry or the workers. This broad picture, though similar to Rybakov's, better fits the historical facts in that it accepts that writers who were not of peasant or proletarian backgrounds consciously chose the form and the viewpoint of a peasant or a worker.

Belaia attempts to assess the general change in style that occurred in the first years after the Revolution. ${ }^{85}$ The break in tradition that many have said to be an essential factor for the flourishing of $s k a z$, she sees as due to a distrust of the Russian literary tradition as irrelevant to the new post-revolutionary world. Writers felt there was a 
sharp divide between bookish discourse and the language of everyday currency. As a consequence, writers like Vsevolod Ivanov, Nikitin and Zoshchenko chose to trust their experience of life rather than the literary tradition. The traditional, many-sided literary representation of the world appeared too passive and contemplative for the representation of the dynamic events of the time. Instead, writers chose forms of a more interpretive character, where the authorial evaluation of events dominates. ${ }^{86} \mathrm{At}$ the same time they attempted to create the impression of the authenticity of the narrated event by conducting the narration from the point of view and in the language of a participant or a voice that sounded like that of a participant in the events. In writing of Fedin's Anna Timofeevna, Belaia stresses that here the authorial (i.e. the impersonal narrator's) speech is constructed according to the patterns of the popular and conversational speech of the inhabitants of the town. Previously such language had only been admissible in the speech of characters:

\footnotetext{
Вскоре такая форма повествовательной речи, где за словом ощущался его прототип - слово героя, где слово героя господствовало, подчиняя себе даже авторскую речь (за которой до тех пор всегда признавалось право на «последнее слово»), где - более того - слово героя становилось основным элементом конструкции, стала восприниматься как новая художественная структура. $^{87}$
}

Reality is here seen from a single point of view rather than by an authoritative and objective narrator who can switch between a number of given points of view. In other words the character gains independence from the author and takes over. Belaia simply describes this phenomenon and does not ponder the analogy it suggests with the events of the Revolution. The shattering of the stable hierarchy of an impersonal, authoritative, authorial voice employing the standard literary language, and an unreliable, partisan character speaking dialect, evokes the razing of hierarchy enacted by the Revolution itself. All revolutions subvert authority, and leave in their wake an 
attitude of suspicion of it for some time. ${ }^{88}$ The supplanting of the author by a character-narrator may well be linked to the suspicion of authority in all its forms.

Yet the discourse of the character was by its very nature unreliable. The language of the people was not suited to the establishing of a new authority. As Lunacharskii noted, it was inadequate to the expression of the complex political ideas that had now gained currency. ${ }^{89}$ Hence $s k a z$ was gradually marginalised, since it was suited to the undermining of authority. In literature, as in life, a stable hierarchy was reestablished. From the late 1920 s onwards, the transparent narrative voice of the novel regained its primacy.

Eikhenbaum takes quite a different view of the reasons for the rise of skaz in this period. He examines the rise of skaz since 1905 as part of a process of the evolution of literary genres rather than an attempt to represent social upheaval. Eikhenbaum sees the novel as the highest achievement of literary culture and maps the path of the novel from spoken to truly written forms. ${ }^{90}$ It reached its apogee in the 1870 s, since when it had been disintegrating into its two constituent parts. These two components are the very process of narration on one hand, and plot, character and description on the other. The novel's plots and descriptive power have been usurped by cinema. Lesser forms, including skaz, became dominant because they give full rein to storytelling, the distinctively verbal form of narration. The nineteenth-century tradition of skaz in Gogol' ${ }^{\prime}$ and Leskov that had been marginalised by the dominance of the novel is seen as coming to the fore in the prose of skaz writers such as Remizov, Zamiatin, Zoshchenko, Vsevolod Ivanov, Leonov, Fedin, Nikitin, and Babel'.

Eikhenbaum sees this disintegration of purely written forms, and hence the dominance of $s k a z$, as a result of the 'mad' but 'creative' character of the epoch expressing itself in the elemental oral language, in opposition to the 'museum' of written culture: all artists are improvisors, but written culture forces the writer, against his inclinations, to choose one variant and to ossify that choice. Eikhenbaum argues that all narration is inherently oral. The short story, of which he sees skaz as a form, 
retains a far greater residue of the primitive narrative art, where all tales were improvisations, and plots were just an outline to be elaborated as the storyteller went along. Skaz, he writes, is an

\author{
освобождение от традиций, связанных с письменно-печатной культурой, и \\ возвращение к устному, живому языку, вне связи с которым \\ повествовательная проза может сусществовать и развиваться только \\ временно и условно. ${ }^{91}$
}

There is a distinct note of celebration in these articles, a kind of dizzy fascination with the eruption of elemental forces similar to that of Aleksandr Blok. Indeed these reflections as a whole bear a strong imprint of their time. The idea that cinema spelt the end of the novel was an apocalyptic overestimation of the former's power, and more than a little wishful thinking on Eikhenbaum's part. Moreover, whilst Eikhenbaum expected the rise of new written forms, the precursor of which he saw in Zoshchenko's 'Strashnaia noch", 92 Russian prose was in fact just about to turn back to the novel.

Nevertheless, if we take skaz to be a form of narration in which the written language recreates certain elements of what it perceives to be the oral mode of narration, it seems legitimate to ask whether the situation of artists in the immediate aftermath of the Revolution made this aspect of skaz attractive.

One aspect of skaz that may have been attractive to writers in the early 1920 s was its manner of fictionalising its readership. A number of accounts have linked the rise of $s k a z$ to the perception of a break in literary tradition. ${ }^{93}$ A literary tradition is at least in part a way of fictionalising the readers of literature. ${ }^{94}$ In a situation where writers perceive that tradition to have been broken, there will consequently be an uncertainty as to the identity of the readership, and their expectations. This is a situation peculiar to print cultures, since all written forms are ways of fictionalising readers: the oral narrator can always see his audience and hear and react to any objections to his story. 
Skaz is a way of fictionalising the reader as a listener, and the author as storyteller. It falls back upon the most basic narrative situation of all, because the literary tradition has collapsed, or has been rejected as an expression of a now discredited bourgeois culture.

Oral culture was not only uncorrupted by bourgeois literary culture, but more in keeping in certain respects with the collectivist ethos of the Revolution. Ong points to the fact that in English, 'audience' is a collective noun whereas 'readers' is a plural and 'readership' an abstract concept. Skaz, which typically addresses its readers as if they were listeners, invites them to imagine themselves as members of a collective that is listening to a live performance. It pretends that it is not a printed work being consumed, as all written works are, in isolation, but an oral performance at which all are immediately present. It pretends to be dynamic and to be occurring before our eyes and ears. This dynamism too creates the illusion of a speaker who has not had time to digest fully the momentous events of the Revolution, but is reacting to them almost as they happen.

This can be seen as a part of Modernism, a final phase of it in the Russian context. However, this is all just an illusion. Skaz is a written form destined to be consumed in isolation by individual readers, and is as mediated and distant from events as any written form. This discrepancy leads us to suspect irony even where none was intended, i.e. even in examples of self-effacing stylised skaz. Some writers were undoubtedly attracted to $s k a z$ for the ironic potential of the discrepancy between its two levels. It was a form in which they could adopt a verbal mask and pretend to be interested and concerned with the Revolution and the people, while in fact adopting an ironic distance to it. Moreover, the difficulty in telling parody from stylisation in skaz made it ideally suited to a bewildered writer not sure how to react, since it could express both enthusiasm and cynicism simultaneously. Victor Erlich argues that it was precisely this 'integrated ambivalence' that attracted writers in the 1920 s as a way of distancing their inner turmoil and evading the censors: 
To an early Soviet writer seeking to come to terms imaginatively with unbearably stark and conflict-producing realities, [skaz] offered obvious advantages in view of its potential for distancing the subject and muting the authorial effect. $^{95}$

Although, as we have seen there were a wide variety of reasons why a writer might be attracted to $s k a z$ in this period, Erlich's point is nonetheless a convincing one. However, skaz as a response to a contradictory situation and skaz as a means of outwitting the censors are different, since the former suggests an interest in masks for their own sake, and the latter implies a firm purpose achieved through the use of a mask, after the model of the so-called Aesopian language. Nevertheless, in the conditions of censorship and political repression obtaining at the time, a writer was unlikely to admit that their intent had been ironic or parodic, even if it had been. Consequently, skaz in this period becomes more ambiguous. Now more than ever before, it is difficult to tell the sincere stylisation from the parody of the language of the people.

Throughout this brief history of $s k a z$, we can see that both parody and stylisation have been at work. Bakhtin's account of the term, developed by Titunik, Levin and Natal'ia Kozhevnikova appears to have been able to describe its uses by the writers discussed here. However, a writer often employs both forms of skaz. Indeed, there are often parodic and stylised elements at work in a single example of skaz. This history has suggested that, in this regard, these critics' treatment of the term needs to be revised.

In this short history we have also been possible broadly to see that skaz is a prose form that has existed in tension with or in opposition to the Realist novel. It should now be possible to make some general statements about the sorts of reasons why a writer chooses skaz rather than the novel. It seems that a writer seeking to transmit a message, or a clear ideology, to create extended narratives, and represent the world 
transparently and economically is unlikely to turn to skaz to further those objectives. If he does do this, he may find that skaz disrupts his intentions, as McLean argued happened with Leskov. A writer may choose skaz for the purpose of stylisation, to introduce hitherto neglected forms of the Russian language into literature. To a greater or lesser extent, this is true of all of the writers discussed here. Yet deviation from the norm language of literary narration is implicit in the use of $s k a z$, and in such cases, parody is never far away. This seems to be why skaz is better at debunking certainties than at affirming them. In many cases it suggests mystery, ambivalence and blind-spots in knowledge. It privileges the fragment and typically serves satirical or irrational and mystical ends. Consequently, it has been most extensively exploited by writers with Romantic or with Symbolist affinities. Even Leskov, who does not fit either pigeon-hole, employs skaz to tell stories about people with a belief in the supernatural, or for satire.

In each case that we have examined, each of the various writers has put skaz to a purpose that was integral to an artistic vision. We must now examine the nature of Zoshchenko's skaz: was it stylised or parodic, or a mixture of the two? Why did he choose to use skaz? Moreover, we must assess the ways in which he adapted skaz, in the form in which he inherited it from the writers I have analysed above, and bent it to his own design. 


\section{Chapter IV}

\section{The Evolution of Zoshchenko's Art: Early Work}

Our analysis of the nature of skaz and review of its previous uses has equipped us to understand what is specific in the way Zoshchenko uses it, and should help us to ascertain his purpose in employing the form. At the same time, the analysis of Zoshchenko's work should aid us better to understand the skaz form. Zoshchenko is the most extreme example of certain possibilities inherent in skaz. Hence to define the specific nature of his work is to understand skaz better. In order to delineate the specific nature of Zoshchenko's use of skaz, we must first chart the evolution of his distinctive skaz form.

Zoshchenko's most significant and original literary works were the short stories and feuilletons he wrote after starting to contribute to the satirical press in late 1922. Whilst the mature work is characterised by a certain ambivalence, Zoshchenko's work up to that point was far more straightforward, and predominantly divided into two groups. The first group comprises works set in the countryside, which are predominantly skaz, and often employ a narrator-participant. The intent in such work is predominantly satirical, and the skaz is overwhelmingly parodic skaz. The second group is formed by works with an urban setting, predominantly St Petersburg (then Petrograd). These stories display signs of the expressive racy urban idiom of Zoshchenko's post-1923 work. However, this language is incorporated through an authorial voice, which is not tied to the linguistic register or the perception of any one character. In other words this language is introduced through the use of ornamental skaz. In this period then, Zoshchenko keeps his use of skaz for parody and satire quite separate from his use of $s k a z$ for the expressive value of the language, by restricting them to distinctly different forms. His post-1923 work blurs such boundaries by employing skaz for the purposes of both parody and stylisation.

Nevertheless, a number of the themes and preoccupations that were to dominate his most successful short stories are already discernible in his early work. Though 
Zoshchenko's most significant development of the skaz form came with his work on the satirical press, some of the later developments are prefigured in this earlier work.

\section{Zoshchenko's Early Unpublished Works 1914-1921}

Prior to the publication of Rasskazy Nazara Il 'icha, gospodina Sinebriukhova in December 1921, Zoshchenko had already been writing for at least seven years. His earliest surviving story is 'Dvugrivennyi' (1914). Its importance is underlined by the fact that it is the only one of the stories of this period that he returned to later. ${ }^{1}$ In this story, an old woman at church thinks she sees a 20-kopeck piece, and in order to get hold of it bows to the ground, as if from pious devotion. What she thought was a coin turns out to be spittle. The narration is impersonal, and we see things initially from a neutral point of view and then from the old woman's own point of view. The language is completely standard, and nothing in the technique points towards the style of Zoshchenko's later short stories. However, here we can already discern a pattern that was to be repeated in the later work, whereby self-interest and the concrete are shown to underlie an action that initially appears to be motivated by a more worthy, abstract purpose. The satirical charge of the story lies in the unmasking of hypocrisy. Here religious devotion is portrayed as a mere appearance masking self-interest. In his later work however, this suspicion of anything that claims to be beyond pettiness and selfinterest came to be reworked in more subtle ways.

The works and even letters of this period are divergent in style, but increasingly hint at Zoshchenko's gift for quickly reproducing a style. ${ }^{2}$ This talent was commented upon by Kornei Chukovskii. Chukovskii at this time ran a studio for would-be literary critics under the auspices of the Vsemirnaia literatura publishing house. In his memoirs, he describes how Zoshchenko developed this ability into a capacity to stylise or parody a style almost at will. ${ }^{3}$

This gift for stylisation and parody was soon to find a specific target that was to serve Zoshchenko for the production of his finest work. In the meantime Zoshchenko was attracted to literary criticism and wrote a number of articles in which he presented contemporary Russian literature as polarised. On the one hand there was the 
intelligentsia, who were moribund and individualistic. In Zoshchenko's view Boris Zaitsev (who was to emigrate in 1922) typified them. On the other hand there were healthy but destructive collectivist barbarians. They were typified by Vladimir Maiakovskii. Zoshchenko praised Maiakovskii in a number of articles at this time for the innovative energy of his neologistic language. He saw this language as raw and primitivist rather than futurist. ${ }^{4}$ Zoshchenko was clearly attracted to the energy of Maiakovskii's personality as well as to his language. It was to serve as an inspiration for his own experiments in producing a literary idiom rich in expressive energy.

Another model for Zoshchenko's linguistic innovation was Aleksandr Blok. Marietta Chudakova has underlined the importance of the poetry of Blok for Zoshchenko, and particularly Dvenadtsat ' which, she argues, Zoshchenko saw as a turning point in (Russian) literature, and the work which first opened his eyes to the possibilities of skaz:

Он увидел в ней решительное изменение всего строя литературы, ее язька. Чужие, не авторские голоса, так решительно введенные в поэму, поновому осветили вдруг возможности схаза. (...)

Не введение разговорной и вульгарной речи - в тех или иных масштабах - в строй поэмы, а замещание ею голоса поэта - вот что, вищимо, было наиболее сильным впечатлением Зощенко от поэмы

It seems to me that whatever the effect of Dvenadtsat', it was not immediate: the decisive turning point in Zoshchenko's stylistic development came later. However, the effect of Dvenadtsat' was certainly important in attracting Zoshchenko towards the language of the people and in raising the question of how that language should be represented in literature. Blok's poem uses the language of the people in a completely new way. Previously Russian writers had tended to use the image of the people and their language as a form of the picturesque, and as part of an exploration of national identity. Gogol' and Leskov used skaz narrators, but there the language of the people is that of the peasantry, and the settings are rural. In Blok's poem the people are violent 
urban revolutionaries. Their language and world-view occupy the centre stage of the poem, banishing the intelligentsia to its margins and threatening them with destruction. If this example was ultimately important for Zoshchenko, it still took him some years before he was to find a genuinely new form, distinct from the examples of Remizov and Zamiatin, in which to represent these people and that language.

\section{Zoshchenko's Early Published Work}

For the most part Zoshchenko's early stories were published in literary journals, such as Krasnaia nov', and are much longer than the typical stories of the period from 1923. They are also more overtly literary than Zoshchenko's post-1923 stories and continue to use skaz as it had tended to be used by previous writers: either as a way of representing the peasantry or as ornamentalism.

This period was one in which Zoshchenko was part of the 'Serapion Brotherhood' of writers. They were formed on 1st February 1921, and their apogee came in 1922: in May they published an almanac and in August, their manifestos. ${ }^{6}$ This group's main defining characteristic was a concentration on the formal aspect of literature, on how it was written as opposed to what it said. Their concern with technique owed much to the thinking of the Formalist critics: their theoretician, Il'ia Gruzdev, had been a student of Eikhenbaum and Tynianov. Skaz was a form that a number of the Serapions employed, for example Fedin, Kaverin and Nikitin. Zoshchenko's initial literary experiments and first attempts in the skaz form can be related to this context. However, none employed it so extensively and so innovatively as Zoshchenko, and his use of it was not typical of the group. Rather, they tended to employ ornamental skaz, continuing to use the form broadly as Zamiatin had been using it before the revolution.

Though Zoshchenko published 'Viktoriia Kazimirovna', part of Rasskazy Nazara Il icha, gospodina Sinebriukhova, in the May 1922 Serapion almanac, ${ }^{7}$ his association with the group soon became extremely distant. Moreover, by 1923, their influence was waning and, despite the ongoing crisis of Soviet literature, Zoshchenko was beginning to find a style he could call his own. ${ }^{8}$ 
Whilst his first published stories were Rasskazy Nazara Il 'icha, gospodina Sinebriukhova $(1921)^{9}$ (hereafter Sinebriukhov) he had in fact already written other stories that were only published after that work. For example, 'Ryb ia samka' (1923) was composed in November-December 1920, 'Liubov"' (1922), 'Voina' (1922), 'Starukha Vrangel"' (1923), and 'Lial ka piat'desiat' (1922) all date from early 1921 and hence were written before Sinebriukhov, which was written in the Summer and Autumn of the same year. ${ }^{10}$ Sinebriukhov stands apart from the rest of these stories, and should be dealt with separately. The other stories composed before 1923, with the exception of 'Pis'ma v redaktsiiu', must be treated as a separate part of Zoshchenko's literary output. These stories are those mentioned above along with 'Chernaia magiia', 'Veselaia zhizn', 'Grishka Zhigan', 'Rasskaz pro popa', 'Metafizika', and 'Uchitel'.

'Ryb'ia samka' (Composed November-December 1920) (SS, I, pp. 94-99) ${ }^{11}$

'Ryb'ia samka' is told by someone sympathetic to the priesthood. The narrator is apparently upset at how little priests are respected, about how powerful women have become and how weak men have become. Humans, he says, are now like fish in Darwin's theories: the female is bigger than the male and will eat him. These generalised reflections it turns out are based on the fact that a cowardly priest finds his wife having sex with their railway technician lodger. The next morning he condemns the government for its undermining of family life and is arrested as a result.

This story is a skaz parody of the language of a peasant. However, the narrator is not a character in the story and this language is combined with the perspective of a narrator who has objective knowledge about everything that has occurred in the village. Though there are digressions that give the narrative a more oral feel, we perceive the narrator as being satirised ultimately because of the inadmissibility of his views and far less through the incompetence of his narration. This is a case of irony far more than one of parody. There are some examples of humorous turns of speech in which the humour derives from the misuse of words: 'okolo zhenskogo klassa' (SS I, p. 97), but these are fairly rare in comparison with, for example 'Aristokratka' (1923). The failed attempt to employ the Marxian lexis of the revolution we find in that story is not characteristic of 
'Ryb 'ia samka': unlike Zoshchenko's later narrators, the narrator of 'Ryb 'ia samka' does not attempt to adapt the discourse of the revolution to his own ends. In general, his views are not parodied by the way in which they are expressed. Instead, the naive, narrowly provincial view of the world, which is presented, is clearly to be read as untrustworthy by the reader of the time. As a result, the reader's relation to the story and its humour is more straightforward than in later stories. The irony here works in a stable binary way. Everything that the narrator says is wrong, because his values, such as his respect for the priest and his views on women, are simply erroneous, according to the standards of the time, and we should understand the precise opposite.

In this story the narrator attempts to link the demise of the priest with larger, abstract themes such as the revolution and Darwinian evolution. In fact the priest's downfall is caused by personal reasons: his wife being unfaithful. There is here a disparity between the narrator's perception of the event and the true nature of it, between the broad sweep of the reasons provided by the narrator and the sordid and mundane nature of the reality we perceive beyond them. This disparity exists throughout the greater part of Zoshchenko's work. After 1923, it was often developed in a far more complex manner. Here it is clearly the narrator's understanding that is at fault, and we perceive the true events clearly, despite his misinterpretation of events.

'Chernaia magiia' (Composed Winter 1921-22) (SS I, pp. 64-74)

The narrator begins the story by saying that the days of black magic are gone, and links black magic to Russia's ignorance and backwardness. Dmitrii Naumych's wife died from black magic, he says. He then starts by telling the story of Vaniushka, who reasons that men are in short supply, and leaves his wife, hoping to find a rich bride. On his way home from a local woman's house he drowns in the river. When diving to look for Vaniushka's corpse, the same thought, that men are in short supply, occurs to Dmitrii Naumych, and he decides to throw out his own wife and look for a more lucrative match. Abandoned with no means of subsistence, Dmitrii Naumych's wife turns to black magic to win him back. A neighbour advises her to put a live black cat into the bathhouse boiler at midnight and when it dies keep one of its bones by her at all 
times. She follows these instructions, but when she opens the boiler to see what has happened, the cat jumps at her, and she dies from fright. Here the narrator says that it may not have been the cat jumping at her, but just some boiling water.

As Dmitrii Naumych is driving past the graveyard that night on the way to town to find a rich bride, he starts to become scared and when a twig scratches him in the face, he screams out. His horse bolts, crashes into a tree and is killed. He comes home, finds his wife dead and realises his mistake.

'Chernaia magiia' has a number of basic similarities with 'Ryb'ia samka': it is set in the countryside, and the narrator's language has a folkloric lilt. It is also like 'Ryb'ia samka' in that the narrator's story disproves his own generalisation: the woman dies not so much from black magic as from Dmitrii Naumych's greediness and heartlessness. He is unable to see this and misinterprets the story because he is extremely limited in his understanding of the world. However, it differs in certain important respects, and in doing so anticipates Zoshchenko's mature style. Here we have a personalised skaz narrator, i.e. one that is also a character, albeit an observer rather than a participant. In this light his misinterpretation of events is due in part to his sharing the same values and interests, as a man, as Dmitrii Naumych. Moreover, unlike the narrator of 'Ryb'ia samka', who is an explicitly dyed in the wool reactionary, the narrator of 'Chernaia magiia' pays lip service to the values of the age by saying that he does not believe in black magic (but it will not do any harm if he talks about it) and by attempting to justify the villagers' methods for finding the drowned as scientific. Moreover, the narrator perceives the advantages of 'evropeiskoe prosveshchenie i kul'tura' to be symbolised by heaters on trams. This is similar to the outlook of the narrator of, for example, 'Bania', who fantasises about American bathhouses. He does not exist in a completely isolated rural world, but has some idea of town life, e.g. trams, and of how city dwellers and foreigners would view his village's belief in black magic. Here we can already see the figure of Zoshchenko's meshchanin: the little man who reduces everything to the little scale of creature comforts.

We are being asked in this story to look beneath the narrator's deliberate misrepresentation of his own views to see what he actually believes. This is nearer to the 
sort of contradictions in the narrator's voice that appear in later Zoshchenko stories. However, it is a simple matter here to see beyond the narrator's transparent attempt to present himself as enlightened. The difference between this story and Zoshchenko's mature style consists in the different way in which the irony functions. Here the target is, as with 'Ryb'ia samka', the backward mentality of rural folk. The positive message of the story is easily reconstructed: attitudes to women must change, belief in the supernatural is harmful, technical progress is good, greed is bad. The backward attitudes of the countryside are very much an officially sanctioned object of satire, and the overwhelmingly urban reader could read this story without feeling any sympathy for the target, and without having to reassess his own behaviour. The satire in Zoshchenko's later period functions in a far more unsettling way. There the narrator makes a direct appeal to our sympathies that is often far harder to discount, but at the same time difficult to accept without reservations. 'Chernaia magiia' is by contrast typical of the earlier stories: it presents us with no difficulties in deciding what to think about the narrator, and is a straightforward use of parody to ridicule.

'Lial'ka piat'desiat' (Composed Winter-Spring 1921) (SS I, pp. 58-63)

'Lial ka piat'desiat' tells the story of Maksim who wants to accumulate enough money to enjoy Lial ka. He gets this money by violently robbing some blackmarketeers. $\mathrm{He}$ is in turn mugged and has no money with which to pay Lial $\mathrm{ka}$.

This story begins with a statement that is immediately tempered by a qualification that completely undermines it:

\section{И какой такой чудак сказал, что в Питере жить плохо? Замечательно жить. Нигде нет такого веселья, как в Питере. Только было бы денежки. А без денег (...) Это точно, что пропадешь без денег.}

This is a technique that Zoshchenko was to use extensively. However, subsequently he developed it so as not simply to undermine the narrator's authority playfully as here, but rather to problematise the narrator's capacity to generalise from and make sense of 
his experience. The style of this initial paragraph is most definitely conversational, and in a substandard but not rustic language. However, the narrator then goes on to tell the story and becomes much more competent. The focus of the story shifts much more to the event that is being narrated. The narrator is not recounting a story that he claims to have eyewitness or immediate and authoritative second-hand knowledge of. There is no limitation of perspective, instead the narrator follows the characters around and has unrestricted access to their unspoken thoughts. The narration itself is at times extremely competent and economic. Moreover, though the language has rustic elements, it is not restricted to a peasant register, and though it employs urban slang, it is not limited to that register either. Instead, the language of the narrator combines those registers with a large vocabulary, including a large proportion of words belonging to the standard literary language. This is skaz as Free Indirect Discourse, ornamental skaz, with an urban setting redolent of Blok's Dvenadtsat' or Zamiatin's stories of the Civil War period. Indeed the technique itself has much in common with the elliptical style of Zamiatin in, for example, Mamai or Peshchera.

Though later the scale of human corruption is smaller and the stakes are lower, the same utterly vitiated world is presented here as in the later stories: the thief robs the blackmarketeer, is robbed by a passer-by, and has no money to pay the prostitute. However, the mixture of comic and tragic here is different. The humour is solely that of an irony of fate. Apart from in the opening paragraph, there is none of the verbal humour so characteristic of the 1920s stories of Zoshchenko. With the exception of the first paragraph, irony here does not function in the manner of the later personalised skaz stories in that we do not have to be so suspicious of everything that the narrator says as potentially incommensurate with the narrative. The narrative is not being conducted by a character, and we are consequently less distrustful of what the narrator says.

Zoshchenko also chooses the ornamental skaz form so as to explore the urban idiom and subject matter in a serious manner. Such a form of narration is less liable to be seen as comic. The result is a more straightforwardly serious reaction to the narrator and what he relates. The same is true, for example of "Liubov"' (SS I, pp. 81-90), which is also narrated in ornamental skaz. There the impersonal narrator's voice interlards elements of 
oral speech with the highly literary. The themes here are less satirical, more an attempt to express the moral chaos of Petrograd at that time. "Liubov" contains very little humour and might be regarded as an example of Zoshchenko's formal experimentation in this period.

In 'Voina', which was composed during the Winter and Spring of 1921, Zoshchenko again uses the ornamental skaz form. However, in this story of reluctant and semimutinous Red Army soldiers, the narrative voice is far more limited than in 'Lial 'ka piat'desiat', and gravitates towards the vocabulary and consciousness of the soldiers themselves. For most of the story, it is as if the narrator was an unnamed member of the group. It is through the exploration of the military theme that Zoshchenko is able to move away from the purely rural associations of skaz. "Veselaia zhizn" and Sinebriukhov mark decisive points in this evolution.

'Veselaia zhizn"' (Composed Winter 1921-22) (SS I, pp. 74-81)

'Veselaia zhizn" is Zoshchenko's first use of $s k a z$ without the introduction of a rural theme. However, as with the $s k a z$ stories set in the countryside, he is still using $s k a z$ for the purely satirical purpose of ridiculing the narrator and his environment. The satire here is directed against the aristocracy and their code of honour. ${ }^{12}$

The narrator reflects upon how times change, and how aristocrats no longer shoot a person who strikes them nor do they commit suicide. To illustrate this, he recounts the story of how a general leaves his wife and falls in love with an actress, but she leaves him, striking him in the process. In response, he does not commit suicide. He later dies of dysentery.

The narrator here has a skaz manner, and the introduction is very much in the chatty manner of the later stories. The main difference is that the narrator uses a lot of the pompous language of bureaucracy, and shows immense respect for the aristocracy. The narrator also knows in some detail what happened to the general, but is not explicitly a character. As is common in these earlier stories, the target of the satire, the old ruling class, is clear. Furthermore, it is an officially sanctioned object of ridicule for Soviet writers. Though the narrator has sympathy for the characters, they are all portrayed as 
cynical swindlers, and the general is clearly a coward. Hence the reader can unequivocally laugh at their misfortunes, and disregard the narrator's stance. Indeed, the narrator himself ends the story by relating the fact of the general's death through dysentery. He does not play upon the possible emotive or tragic effect of that event. Rather, it is unmotivated: a narrative deus ex machina. As a result it is comic.

\section{Rasskazy Nazara Il'icha gospodina Sinebriukhova}

(Composed Summer-Autumn 1921. Published end of December 1921) (SS I pp. 2658)

This cycle of stories recounts the eponymous narrator's adventures during the First World War, the Revolution and in the immediate aftermath of those events. Marietta Chudakova is typical of commentators who have seen Sinebriukhov as the most significant of Zoshchenko's works of this period. ${ }^{13}$ Such critics praise this cycle of stories particularly for its accomplished use of personalised skaz narration, and its mixture of conflicting registers of speech. ${ }^{14}$ It is certainly true that the use of personalised narrator-participant skaz appears here for the first time in Zoshchenko's work. This permits the narrator to make a direct appeal to our sympathies, and permits his actions and the reactions of others to counteract his own opinion of himself.

However, the irony in Sinebriukhov functions like that of the earlier satirical stories, such as 'Chernaia magiia' and 'Ryb'ia samka'. The fact that Sinebriukhov is himself such a fool means that the reader tends to feel, at the most, pity for him rather than sympathy. Consequently, the irony here is straightforward, and functions like dramatic irony, where the audience sees what the characters cannot. Here we immediately see that the other characters want to swindle Sinebriukhov, but his inability to see this allows us to take a distance towards him that is not possible with the narrators of Zoshchenko's later works.

Like most of the other skaz narrators in Zoshchenko's work of this period, Sinebriukhov is a peasant, but unlike all the others with the partial exception of 'Veselaia zhizn", his language incorporates many other registers of language that he has picked up during his time in the army. The difference with the later narrators is that they are far 
more urban, and more roguish rather than foolish. Sinebriukhov is far more like the other rural narrators (e.g. of 'Ryb'ia samka' or 'Chernaia magiia'), he has simply got it all wrong, and we can simply disregard his judgements. With the later narrators, we concede some points but conclude that they have got it wrong on others. The urban narrators have more convincing pretensions to knowledge, to an understanding of the world and to being good Soviet citizens. Their generalised statements have a certain attractiveness. These effects come about in large part through the adaptation of the journalistic forms of the time to personalised skaz narration such as that used in Sinebriukhov.

Nevertheless, Sinebriukhov is an extremely well worked example of skaz. It strains at the boundaries of the rustic tradition of $s k a z$, in that the narrator's language has already been corrupted by the modern world even though he remains a peasant at heart. In this it points forward to the ways in which Zoshchenko was to develop the skaz form in the coming years.

Writing in 1932, Zoshchenko claimed his first published stories were a mistake:

Первые мои литературные шаги после революции были ошибочны. Я начал писать большие рассказы в старой форме и старым, полустертым языком, на котором, правда, и посейчас еще иной раз дописывается большая литература.

Только через год, пожалуй, я понял ошибху и стал перестраиваться по всему фронту. ${ }^{15}$

However, for all their difference from his later work, in these stories Zoshchenko clearly established the central themes that were to dominate his work for the next ten years: the revelation of self-interest beneath an apparently disinterested interpretation.

Furthermore, Iurii Tomashevskii sees the stories of this period as a kind of stylistic apprenticeship, in which Zoshchenko gained the experience that enabled him to reinvent the Russian literary language: 
Работа над «большими рассказами» (...) помогла ему овладеть приемами традищионной стилистики русского литературного языка, без чего вряд ли ему удалось бы столь искусно и в столь короткие сроки перестроить привычную литературную речь тахим образом, что она стала понятна людям, только что прихоснувшимся к культуре. ${ }^{16}$

In this period, Zoshchenko certainly experiments with a number of forms, and elaborates devices that were to serve him in his later work in the 1920 s. In 'Lial' ka piat'desiat', as we have seen, he employs the device of asserting something and adding a qualification that effectively contradicts the original assertion. In Sinebriukhov, he uses a similar but different device, whereby a generalised claim is undermined by the story that follows it. Examples of this are Sinebriukhov's boastful claims to be a good storyteller and all-round handyman, which are undermined by what we learn about him from his own narrative. These devices were to be transformed by being employed in the new context of Zoshchenko's work on the satirical press, and made to serve a purpose that was not simply satirical.

Nevertheless, it seems to me that Zoshchenko was broadly correct in his later analysis of his early work. Prior to his involvement with the satirical press, his stories were very much a continuation of previous literary trends. ${ }^{17}$ They can be described through Levin's distinction between skaz proper and 'unclassical' forms of narration (i.e. ornamental skaz). Skaz proper reproduces the language of a social type defined by linguistic deviation from a 'classic' literary norm. Leskov's stories are an example of this. 'Unclassical' forms of narration tend towards the remodelling of the literary language. They retain the narrator and the resources of the literary language, but add to and develop them with the resources of conversational and popular speech. Examples of 'unclassical' forms of narration are Belyi and Remizov. ${ }^{18}$ Zoshchenko, in much of this early period of his work, continued to write skaz that gravitated to one or another of these types of $s k a z$, depending on the subject matter: where skaz proper is used it is to explore the style of speech and mentality of the peasantry. They are satirised by reference to an implicit literary norm. Where the urban theme is explored it is through 
the use of the 'unclassical' form of narration (i.e. ornamentalism), and the narrator's language is not the object of ridicule. On the contrary it presents itself as a liberated, post-Symbolist prose style.

Zoshchenko's distinctive prose manner, however, was an attempt to create a completely new Russian literary language dependent on neither the 'unclassical' form of narration nor on skaz proper. This was a form that employed a language that was being both parodied and stylised, and a narrator who was not a peasant but a meshchanin to whom we ultimately feel sympathy as well as antipathy. The catalyst for this transformation was the satirical press. Highly accessible quasi-journalistic forms suited Zoshchenko's attempts to democratise and simplify the literary language as well as suiting the exploration of the themes of human selfishness and deceit that Zoshchenko had adopted since his earliest attempts at fiction. This new language, when combined with the use of a skaz narrator, became inextricable from the ambiguous view of the world that the stories present.

\section{3: Zoshchenko's Year of Transition}

1923 was a transitional year for Zoshchenko. During the course of this year he quickly moved away from the peasant theme and the peasant skaz narrator; he also wrote his last ornamental story, 'Starukha Vrangel'' (SS I, pp. 100-07). The influence of the Serapion Brotherhood, who were particularly associated with the ornamental form, was waning fast. His new skaz and journalistic styles were still in the process of formation. It was at this point in his contributions for the satirical press, at first Drezina (the satirical supplement to Gudok) in particular, that Zoshchenko started to elaborate the size of story, and then the language, narrative voice, style and humour of his most characteristic form.

In some of his initial work for the satirical press, Zoshchenko's irony is the irony of fate rather than that of humour. Such a tone was present in the ornamental skaz stories discussed above. This loss of humour may be ascribed to a certain difficulty in adjusting from satirical literature to satirical journalism. It is, moreover, significant that skaz short stories such as 'Plokhaia vetka' (SS I, pp. 128-29) and 'Distsiplina' (SS I, pp. 126-28) 
employ $s k a z$, but this is no longer parodic skaz used to satirise the narrator, as with 'Ryb 'ia samka', 'Chernaia magiia' and Sinebriukhov. Instead, it tends towards stylised skaz. Shortly, Zoshchenko was to perfect the skaz short story in which stylised and parodic skaz are combined to create both humour and the irony of fate.

Zoshchenko's short stories from 1923 to the end of the decade can be broken down into a number of categories. It should however be conceded that these classifications are necessarily inexact. It is difficult to determine the precise degree a narrator's language needs to deviate from the neutral authorial norm of the standard literary language and employ the language of the people in order to qualify as skaz. Nevertheless, I classify as skaz texts in which some deviation is noticeable.

i) The first group is that of short stories that are not skaz. These exist in two variants. In the first the narrator is not a character, and hence his knowledge of the characters and events is not limited in any way. Unlike the skaz narrator he does not offer his opinion; instead the events themselves offer commentary. Examples are 'Uchitel”' (SS I, pp. 122-23), 'Sila talanta' (SS I, pp. 145-46), 'Novyi chelovek' (SS I, pp. 154-55), and 'Pisatel" (SS I, pp. 155-57).

His role is usually minimal and may consist in simply establishing a location for a story narrated mostly in dialogue. ${ }^{19}$ This is the case in for example 'Agitator' (SS I, pp. 157-59).

The other variant of the non-skaz short story is where the narrator is a character in the story, usually identified as the writer himself. There are far fewer of these. 'Senator' (SS I, pp. 132-36), and 'Tochka zreniia' (SS I, pp. 275-76) are examples of this type of story.

This form of short story is essentially a continuation of the Chekhovian forms of short story. With both of these types of short story there is a tendency for the humour to be less linguistic, and more based on the strangeness and irony of events. In both cases the narrator's language is too neutral and too close to the standard literary language to be called skaz. Moreover, rather than the narrator's opinions, it is the main character's opinions, and events that are unstable (e.g. 'Sila talanta', 'Liubov'" (SS I. pp. 193-95)). 
There are nine stories that are not narrated in the skaz manner, out of the 32 stories included in the 1986 collected works for 1923 . This represents just under a third of the stories published in this year. Such stories become proportionally less significant when the three feuilletons from the 1986 edition are included: they are all skaz. The 47 other works published in 1923 included in Uvazhaemye grazhdane are mostly journalistic and have at least some conversational elements in the albeit often very short narratives, thus making them skaz. In sum then, short stories not narrated in the skaz manner make up just over a ninth of Zoshchenko's published works for 1923.

There is a more significant proportion of short stories that are not skaz in 1924: of the 39 stories and three feuilletons that appear in the 1986 edition 14 are not told in the skaz manner. Of the 23 stories that appear in Uvazhaemye grazhdane, six are not skaz. Stories not told in the skaz manner make up 20 out of 65 , that is to say under a third of Zoshchenko's published stories for this year.

From 1925 to the end of the decade the non-skaz short story is completely marginalised. The year 1925 is typical: nine out of the 35 short stories, two out of the 22 feuilletons in the 1986 edition are not written in skaz, and one out of the 31 stories and feuilletons that appear in Uvazhaemye grazhdane is not in skaz. For 1925 then, 12 out of 88 stories are not in skaz. This represents approximately one seventh of Zoshchenko's published work for that year. Similarly, in 1926 only two out of the 25 stories included in the 1986 collected works are not told in the skaz manner: all of the six feuilletons included in that edition are in $s k a z$, as are the four feuilletons and short stories included in Uvazhaemye grazhdane. In other words six out of 35 short works published that year are not skaz. At this point proportions become so insignificant as to become meaningless. Of the 69 short stories and feuilletons included in the 1986 collected works for the years 1927, 1928 and 1929, only two cannot be confidently classed as skaz. All of the 51 short stories and feuilletons collected in Uvazhaemye grazhdane for the same period are written in skaz.

In sum then, of the 390 short stories and feuilletons published by Zoshchenko in the years from 1923 to 1929,45 were not written in skaz. That is to say approximately a ninth, an insignificant proportion. This may be expressed in the form of a table: 


\begin{tabular}{|l|c|c|c|}
\hline Year & Total & non-skaz & $\%$ \\
\hline 1923 & 82 & 9 & 10.98 \\
1924 & 65 & 20 & 30.77 \\
1925 & 88 & 12 & 13.64 \\
1926 & 35 & 2 & 5.71 \\
$1927-29$ & 120 & 2 & 1.67 \\
\hline Total & $\mathbf{3 9 0}$ & $\mathbf{4 5}$ & $\mathbf{1 1 . 2 5}$ \\
\hline
\end{tabular}

As we can see from the figures, the impersonal skaz form of narration and particularly narrator-participant skaz merge with the feuilleton form from 1925 in particular, and the impersonal form of narration disappears for some time. It reappears in the 1930s and becomes more important then, as the skaz element of Zoshchenko's work is toned down in favour of more standard and neutral forms.

ii) During 1923 Zoshchenko begins to employ narrator-participant skaz increasingly. This is one of his most characteristic forms. As we have seen, skaz tends towards characterisation: the skaz narrator incorporates certain language and a fallibility that are normally permitted the characters but not the narrator. In narrator-participant skaz, the narrator is not just a character, but either the main protagonist of the story or so near to the events of the story so as to be caught up with them and incapable of delivering unbiased judgement on events. ${ }^{20}$ One variant of the narrator-participant skaz is where there is a neutral frame that introduces the narrator-participant. Typically the frame is trustworthy and neutral (though this is not the case in 'Schast'e' (SS I, pp. 211-14) for example). While initially narrator-participant skaz stories such as 'Aristokratka' (SS I, pp. 170-73) are distinct from the explicitly written stories employing the letter or memoir forms such as 'Gor'kaia dolia' (SS I, pp. 141-43) and 'Madonna' (SS I, pp. 115-22), later in 1924 and especially in 1925, the narrator-participant form tends to merge with the more journalistic forms, particularly through the model of the letter of complaint, in which the person complaining draws from their own experience. 
The narrator-participant is the extreme possibility of $s k a z$ as a whole, in which the narrator's language and perspective take on characteristics and limitations usually associated with characters. Though also an extreme possibility within Zoshchenko's own art, this narrative form is nevertheless the most explicit form of a tendency that runs throughout his 1920s short stories. The narrator-participant is a form suited to expressing an incapacity to generalise, since the narrator can make sense of the world only insofar as it relates to him. He can neither tell a story that he has invented nor even one about anyone else. That would demand too great a capacity for abstraction beyond immediate experience. He draws on his own experience and generalises from it, but the generalisation typically is an unconvincing account of his experience. As we shall see, this incapacity to generalise need not be solely a source of humour, but also an admirable limitation.

iii) In 1923, the other skaz form that Zoshchenko developed was skaz which employs an impersonal narrator. In such skaz stories as 'Vor' (SS I, pp. 136-40), and 'Sobachii sluchai' (SS I, pp. 140-41), the narrator is not a character, but he is definitely not a standard literary narrator. He fully shares the value system of the character and even assumes that the reader will too.

It should be noted that throughout this period Zoshchenko continued to write his eight longer short stories, known as the Sentimental'nye povesti. These broadly belong to this category of impersonal skaz narratives. However, the main characters of these stories are members of the old intelligentsia who have fallen on hard, post-revolutionary times, and they are not treated with sympathy by the narrator, as is the case with the shorter stories. Consequently, the element of parody clearly predominates, as with the earlier peasant skaz stories. Moreover, in these stories, the more extended form enables Zoshchenko explicitly to explore his deeper 'philosophical' themes, such as the 'grustnaia povest' o krushenii vsevozmozhnykh filosofskikh sistem' in 'Liudi' (1924) (SS II, pp. 58-88 (pp. 59-60)). In the shorter stories, such questions are not explicit, and only an investigation into their form can uncover them. 
These two skaz forms of narrator-participant and impersonal skaz Zoshchenko increasingly adapted to thie purposes of the satirical press, particularly after 1924 . This is not to say that all of Zoshchenko's skaz short stories show direct evidence of the influence of the journalistic forms of the satirical press. They do not. Nevertheless, that influence was significant, and enabled him to develop a subject matter that was already his own, and to develop skaz forms particular to him. After his first contact with the satirical press in 1922, the influence of skaz became more and more significant during the course of 1923. The period from 1923 until the end of the 1920s was the high point of Zoshchenko's career. It was in this period that he wrote his best comic short stories, the works with which he gained his reputation as a writer, and which, despite their small size, still dwarf the rest of his work in significance. 


\section{Chapter V}

\section{Zoshchenko's Skaz and Journalism}

The starting point for our search to understand the workings of Zoshchenko's skaz lies in ascertaining whether Zoshchenko is employing stylised or parodic skaz. This means understanding his consciously held attitude to the style and mentality of his skaz narrator. In order to define that relation, we must first determine the characteristics of the style, its most typical forms, and attempt to form a picture of the sort of person who would use such a style and such forms. The most significant of these forms are the journalistic feuilleton and the letter of complaint. Before evaluating the precise nature of the relation of these forms and their style to Zoshchenko's stories, we must first describe them.

This chapter comprises four sections: the first three are shorter and introduce my analysis of Zoshchenko's short stories in the larger, fourth section. In the first section, I describe the general context of 1920s Soviet newspaper culture and of the satirical press. In the second section I examine Zoshchenko's attitudes to both journalism and literature as expressed in his articles and other statements about his art. The third section is a detailed examination of the dominant forms of the satirical press in the 1920 s and the ways in which they functioned. Here I also suggest, in general terms, the relevance of these forms for Zoshchenko. The fourth and main section of this chapter is an in-depth investigation into the influence of journalistic forms on Zoshchenko's short stories.

\section{i) The Soviet Press}

\section{Newspapers in Revolutionary Russia}

On coming to power, the Bolsheviks completely transformed popular culture in Russia. In place of pre-revolutionary Russia's sensationalist popular fiction, religious texts, and commercially driven journalism, they introduced a completely new 
newspaper culture. Lenin and the party leadership, who were effectively former journalists, demanded that Soviet newspapers perform an important political role. After a process of adaptation to the language of the mass of the people in the early $1920 \mathrm{~s}$, the mass press became the most accessible form of printed material during the Soviet era and a vital political tool. ${ }^{1}$

At the same time Russian literature was undergoing a profound crisis of form, and there was a demand that the material for literature be contemporary. Many writers turned to journalistic and pseudo-journalistic forms. ${ }^{2}$ Zoshchenko at this time was still experimenting with a number of styles of writing (see above Chapter IV). He tried his hand at journalism too, and soon found that his proclivity for recreating other people's styles could be amply indulged in the prevalent journalistic forms. Meanwhile, the Serapion Brotherhood was fragmenting: with the closing down of Dom iskusstv in 1923, the Serapions lost their base, and with the death of Lev Lunts in 1924, they lost their unoffical leader. Zoshchenko began to drift away from this more properly literary grouping, and away from more conventionally literary forms. Increasingly, he gave himself over to journalistic forms. He soon became the most successful Soviet writer to have done so. ${ }^{3}$

\section{The Satirical Press}

A specific feature of the newspaper culture of this period were satirical journals, which started life as supplements to the major papers. Zoshchenko's first publication in a 'tonkii' or 'thin' journal, the satirical magazine, Mukhomor, came in December 1922, within a year of his first publication. ${ }^{4}$ The story was 'Metafizika', which differs little from the rest of the stories he published that year. However, in the next issue of that magazine he published a feuilleton, 'Pis'ma v redaktsiiu' (SS I, pp. 449-51). This was a series of fictional letters of complaint signed with pseudonyms. Here for the first time Zoshchenko employs a journalistic form, the letter of complaint. Fictional personae indignant at unmerited misfortunes make aggrieved appeals for sympathy. 
It was through his work on the satirical press that Zoshchenko developed his distinctive style. His already proven flair for reproducing styles was now applied to the letter of complaint and feuilleton forms. His language became more succinct and distinctly urban. The choice of this language and these forms is part of a deliberate programme to democratise literature and make it more accessible. Before analysing these forms and Zoshchenko's use of them I propose to examine Zoshchenko's views on his own work, and his comments about journalistic and documentary forms especially.

\section{ii) Zoshchenko's Views on Literature \& Journalism}

Zoshchenko's statements about literature were written from the late 1920s onwards in response to intense criticism of his work. ${ }^{5}$ They were a retrospective defence of the way in which he had been writing since 1923. The principal accusations that he reacts to in them are that he has been corrupting the Russian language for trivial humorous purposes and that his preference for the short story form proves that he is an ephemeral humorist. ${ }^{6}$ Throughout these articles, in defending the language and the forms that he had been employing since the early 1920s, Zoshchenko also sets out his view on the sort of literature the Soviet Union needs. Likewise, he argues that the way in which he has been writing is a correct response to those needs.

So notable a critic as Kreps dismisses these statements outright, arguing that they should be disregarded altogether because they were written under conditions of censorship. Whilst this is true, and we must be careful when reading them to bear censorship restrictions in mind, it is surely still possible to make sense of their contradictions. Moreover, these statements suggest weaknesses in Kreps's account of Zoshchenko simply as a parodist, and it may well be that he disregards them because they do not fit his account of Zoshchenko's skaz. I propose that we can read these contradictory statements of Zoshchenko's intent in adopting the mask of a skaz narrator as trustworthy: it is precisely their contradictory character that is to be 
trusted, since it points to contradictions present in the stories themselves, and in the very nature of skaz. Taken as a whole, Zoshchenko's later programmatical views and defences of his art, from 1927 to 1937, shed light on his earlier fictional practice and articulate a consistent vision of form and style. The kernel of Zoshchenko's argument is that the contemporary reader needs accessible literature written in a concise style and short forms. He claims that his work is an attempt to respond to this demand, rather than simply to follow literary tradition. Zoshchenko at a couple of points even suggests that it is not just literary traditions that must be broken with, but even literature as such. He advocates documentary writing or journalistic forms such as the feuilleton and the very short short story, as the forms most suited to the postrevolutionary literary readership.

In his first article on this subject, 'O sebe, o kritikakh i o svoei rabote' (1927), Zoshchenko begins by considering accusations that his work is trivial, and that he is not a proper writer:

\title{
A так хак большая часть моих вещей сделана в неуважаемой форме - журнального фельетона и коротенького рассказа, то и судьба моя обычно предрешена. (Uvazhaemye grazhdane, p. 585)
}

He rejects such accusations, and argues that what society needs is a literature that does not ape the models of the Russian classics, but uses precisely those lesser forms that he was being criticised for employing:

\begin{abstract}
А относительно мелкой литературы я не нротестую. Еще неизвестно что значит сейчас мелкая литература.
\end{abstract}

Вот в литературе существует так называемый «социальный заказ». Предполагаю, что заказ этот в настоящее время сделан неверно.

Есть мнение, что сейчас захазан храсньй Лев Толстой. 
(...) [но] вся жизнь, общественность и все охружение, в котором живет сейчас писатель, заказывают конечно же не храсного Льва Толстого. И если говорить о захазе, то заказана вещь в той неуважаемой мелкой форме, с хоторой, по храйней мере раньше, связывались самые плохие литературные традищии.

Я взял подряд на этот заказ.

Я предполагаю, что не ошибся.

В высокую литературу не собираюсь лезть. В высохой литературе и тах достаточно писателей. (Uvazhaemye grazhdane, p. 585)

Zoshchenko advocates the use of forms that before the Revolution had been associated with 'the worst literary traditions' as a way of democratising literature and making it accessible to new readers. He is presumably referring to the fact that the forms he adopted were pioneered in the satirical press, and were considered to be of low literary value.

This vision of a dichotomy between a greater, respectable, traditional literature and a lesser, unrespectable literature runs throughout these articles. The related notion that his choice of forms was determined by the need to break with the main-stream of the pre-revolutionary literary tradition is further developed in a subsequent article, 'Kak ia rabotaiu' (1930). ${ }^{8}$ Here Zoshchenko discusses his early, longer stories, that is his work before his debut in the satirical press, and condemns their form as inappropriate and traditional:

Мне показалось в дальнейшем, что форма большого рассказа, построенная на старой традиции, есть чеховская форма и [она] менее пригодна, менее гибха для современного читателя, которому, мне похазалось, лучше дать храткую форму, точную и ясную, чтобы в ста или пятидесяти строчках был весь сюжет, нихахой болтовни. Тогда я перешел на храткую форму, на маленькие рассказы. (Uvazhaemye grazhdane, p. 590) 
Zoshchenko also argues in 'Kak ia rabotaiu' that the present-day writer must write accessibly so as to interest the masses in literature. To do this 'nuzhno pisat' iasno, kratko i so vsei vozmozhnoi prostotoi' (Uvazhaemye grazhdane, p. 589). The need for Soviet literature to write in a new way is also emphasised in 'Avtobiografiia' (1932). Here Zoshchenko again reviews his literary career, emphasising that the way that he writes was determined by the demands of the post-revolutionary situation:

Я сразу столкнулся с труднейшей задачей - писать для новой страны, для новых, еще неизвестных читателей. (Uvazhaemye grazhdane, p. 591)

Zoshchenko repeatedly upbraids those who write in the old language of the intelligentsia and continue the traditions of the old literature, 'kak budto $\mathrm{v}$ strane nichego ne sluchilos" (1929) (Uvazhaemye grazhdane, p. 371). ${ }^{9}$ They are condemned as 'red Lev Tolstois', writers whose sentences are as artificial as those of Russian literature before Pushkin. The Formalist critic Viktor Shklovskii, is, by contrast, held up as a model for making his sentences short and readable. Zoshchenko claims to have done the same:

Я пишу очень сжато. Фраза у меня короткая. Доступная бедным. Может быть, поэтому у меня много читателей. (1930) (Uvazhaemye grazhdane, p. 586)

Zoshchenko presents his form, style and language as a democratisation of literature in line with the demands of the Revolution and the new readership that it produced. He repeatedly refers to his large readership as evidence that he has succeeded.

Though Zoshchenko was not a member of any literary grouping after increasingly drifting away from the Serapions from late 1923, these defences of his art appear to 
echo the views of the Novyi lef Constructivists, who were also formulating their views on literature from 1927.

The Constructivists were the most extreme of those voices demanding a fusion of life and art. ${ }^{10}$ Such currents had been around since the very start of the Revolution. ${ }^{11}$ An example of Constructivist practice was the filmmaker, Dziga Vertov, who believed art to be inherently counter-revolutionary, and pioneered a new style of documentary film journalism. ${ }^{12}$

In particular the Constructivists condemned the notion that Soviet literature needed a 'red Tolstoi', as part of a mistaken understanding of the cultural needs of the new society. They argued that the new society could simply not make any use of the art forms of the past. It did not need contemplative, passive, art and literature, but new journalistic forms such as the active reworking of facts. ${ }^{13}$ This perspective, particularly in its disdain for tradition, is remarkably close to Zoshchenko's views on art expressed in this period, right down to the admiration for Shklovskii, who was a contributor to Novyi Lef and a pioneer of non-fictional forms. ${ }^{14}$ Moreover, we have already seen evidence of Zoshchenko's admiration for Maiakovskii, the most prominent figure in Constructivism (above, Chapter IV).

Yet Zoshchenko remained his own man, and some of this resemblance is quite possibly the result of similar reactions to the cultural climate of the $1920 \mathrm{~s}$, rather than an indication of any direct influence. Certainly the Constructivists make no mention of Zoshchenko in their articles, and Viktor Shklovskii was a figure whose influence and appeal surpassed that of Constructivism.

Nevertheless, Zoshchenko's work contains a substantial documentary component that has never been evaluated adequately. ${ }^{15}$ This orientation in his work runs from the early 1920s unbroken to Pered voskhodom solntsa. The initial impetus behind the documentary and journalistic bias of his work was the attempt to attract readers who had not previously been interested in literature, and therefore had no connection to the existing literary tradition through the turn to forms that were themselves outside the mainstream of the literary tradition. For Zoshchenko, the most significant of these 
was the pseudo-documentary journalistic form of the feuilleton. The feuilleton genre is highly dependent on the use of factual material, in particular readers' letters. ${ }^{16}$

As well as employing the feuilleton proper, Zoshchenko's short stories also mirror the structure of the feuilleton. In particular they frequently rely on factual material: Zoshchenko reckoned that 30 to $40 \%$ of his stories were based on incidents that he had read about in the papers ('Kak ia rabotaiu', Uvazhaemye grazhdane, p. 589).

The motive behind the journalistic orientation of his work was to attract readers who showed no interest in literature, but who appreciated journalism. In Pis'ma $k$ pisateliu (1929), one of the letters ('Pis'mo rabkora', Uvazhaemye grazhdane, p. 427) praises the collection of feuilletons in the writer's recent collection, Nad kem smeetes'. This rabkor prefers facts to authors' 'fabrications', and asks Zoshchenko to get Zemlia i fabrika publishing house to print more collections of feuilletons. ${ }^{17}$ There is more than a slight suggestion that Zoshchenko himself has great sympathy with this rabkor's point of view. Furthermore, this kind of reader was precisely who Zoshchenko had in mind when employing the feuilleton and feuilleton-influenced short story forms:

\footnotetext{
Я немного изменил и облегчил синтаксис и упростил композицию рассказа. Это позволило мне быть понятным тем читателям, которые не интересовались литературой. (1933) (Vozvrashchennaia molodost', SS III, p. 158).
}

Similarly, in 'Kak ia rabotaiu', reiterating his demand that literature should be written so that the people understand it, Zoshchenko writes: 'Neobkhodimio massu interesovat' literaturoi' (Uvazhaemye grazhdane, p. 589). Attracting extra-literary readers in fact meant employing not only extra-literary language, but also extraliterary forms. With his simple language and journalistic forms, Zoshchenko did both of these things. 
The question of documentary literature is not discussed at great length in Zoshchenko's articles. However in a 1930 letter to Gor'kii, Zoshchenko argues that not only 'high' literature, but fictional works as such are irrelevant:

\section{Я всегда работал по самым мелким журналам и всегда старался} удерживаться от «высохой литературы». Сейчас я, например, работаю на заводе в стенной цеховой газете и в печатной заводсхой. А сам вызвался на эту работу для того, чтобы видеть всю жизнь и принести хахую-нибудь пользу, так как, сколько я понимаю, художественная литература сейчас мало существенна и мало хому требуется. ${ }^{18}$

Zoshchenko continued to keep his critical distance from the purely literary form of literary tradition. Even as late as 1937, in an article entitled, 'Osnovnye voprosy nashei professii', ${ }^{19}$ Zoshchenko argues that Soviet literature is a literature of fact. Here he raises his objections to fictional literature, and claims that all successful Soviet novels have introduced new extra-literary elements: e.g. history, chronicle, memoir or science. They are not novels of the purely literary type. Vsevolod Ivanov, Aleksei Tolstoi and Sholokhov all 'freshened up the form with interesting facts':

Я не знаю дальнейшей судьбы советского романа, однако пока что в романе явственно намечается линия факта, истории и документа в художественной переработке (...) в наших удачных романах мы находим элементы факта, которые освежают старую форму (...)

И мне думается, что именно тут в области факта (я беру широко: история, наука, воспоминания) могут быть отхрыты новые жанры. А те жанры, какие мы знаем, - недостаточны и литература вряд ли на них остановится.

Тут нужно побольше смелости, риска и поисков. Тут могут быть интереснейшие открытия. 
Я лично делал опыты в этой области, в области факта.

Мои последние работы «Письма х писателю», «Возвращенная молодостъ» и «Голубая книга» - это поиски нового жанра.

Но это поиски не ради самого жанра, а ради темы, хоторую я не мог подать в устаревших формах. (1935-37, pp. 378-79)

This statement is in part misleading in that he is drawing parallels with other writers, who have 'artistically reworked' history, documents and facts. This formulation stresses the similarites between him and more mainstream Soviet writers, and is so broad as to include the historical novel. In stressing these resemblances, Zoshchenko is disguising some profound differences: his reworking of facts at times really is journalism and is never far removed from it, whereas historical novels are explicitly fictional.

Nevertheless, this article does point to a contradiction in Zoshchenko's work: even at its most journalistic, it is not free from the author's hand; it is still a 'reworking of facts'. Zoshchenko stresses this in the 1932 'Avtobiografiia' when he says that he has exaggerated the language of his works. Not to have done so, he argues, would have resulted in photography, not art.

The insistence that his work is art and not 'photography' stands in contradiction with much of what Zoshchenko says elsewhere about literature. This contradiction reveals a tension that runs throughout Zoshchenko's work: Zoshchenko's stories of the 1920s, for all their use of the feuilleton form, are also works of literature. They are both journalism and literature. The feuilleton form itself oscillates between the newspaper article and the short story. In the hands of the most able practitioners of the form such as Il'f and Petrov, Kataev as well as Zoshchenko, the feuilleton form became close to and even indistinguishable from the short story. ${ }^{20}$ These writers' use of the feuilleton form enabled the short story to be rejuvenated.

Yet Zoshchenko claims to be employing the feuilleton form for its factual and extra-literary character: 
В этих фельетонах нет ни хапли выдумхи. Здесь все голая правда. Я решительно ничего не добавлял от себя. Письма рабкоров, официальные документы и газетные заметки послужити мне материалом.

Мне кажется, что именно сейчас существует много людей, которые довольно презрительно относятся $\mathbf{x}$ выдумке и $\mathbf{x}$ писательской фантазии. Им хочется настоящих, подлинных фахтов. Им хочется увидеть настоящую жизнь, а не ту, которую нодают с гарниром товарищи писатели. В этих моих фельетонах есть драгоценное свойство - в них нет писателя. Вернее: в них нет писательской брехни. ('Ot avtora', SS I, p. 448)..$^{21}$

This appears to be a straightforward statement of Zoshchenko's commitment to documentary journalism. However, even after so apparently categorical a statement, he hesitates and admits that he has changed some names, before repeating his claim that the feuilletons are all 'the naked truth'. This is clearly not so: the feuilletons contain much that appears to have been liberally fictionalised. ${ }^{22}$

This indecision is typical of Zoshchenko, and is a revealing instance of his ambivalent intentions in reproducing journalistic forms: Zoshchenko is making a serious attempt to attract new readers by democratising literature and bringing it closer to life by using journalistic fact based forms. At the same time he is using parody to ridicule such forms and those who would write in such a manner. Documentary material is important, but it is reworked and exists in tension with literary licence. This results in an ambivalent attitude to the literature of fact. This relation to documentary literature, as we shall see, is not the only contradictory position that Zoshchenko adopted. Irresolvable contradictions seem to have lain at the heart of Zoshchenko's creative enterprise. In his work, the tensions between documentary journalism and art, between fact and interpretation, are transformed and deepened into the expression of an existential conflict. In order to examine this 
strategy in detail we must enumerate those journalistic forms that Zoshchenko was to employ, stylise and parody in his short stories.

\section{iii) 1920s Soviet Journalism: Form, Style and Outlook}

\section{The Feuilleton}

The dominant form of satirical journalism of the 1920 s was the feuilleton. A feuilleton is a journalistic genre originating in France around 1800 and first used in Russia in Vestnik Evropy in 1820. In the Soviet Union a century later it became one of the most common forms of satire. The generic characteristics this form acquired in the Soviet Union need to be outlined in order to trace the specific stylistic and thematic influences of the satirical press on Zoshchenko.

In his history of the feuilleton in Russia and the Soviet Union, Leonid Ershov shows how, after the Revolution, this form became highly politicised. ${ }^{23}$ From 1918 to 1921 the 'small feuilleton' predominated. This genre developed from the critical notice [zametka] or sketch [ocherk] in Pravda and Izvestiia. These were often based on facts gleaned from letters to the paper, in particular from rabkors (worker correspondents). In this period information prevailed over humour and what little humour there was tended to ridicule the Soviet Union's enemies crudely. However, in the years 1922-1923, a new form, 'the large feuilleton' came into being. Here the quantity of information was reduced and the elements of humour and the dramatisation of the situation became far more significant. Though art was subordinate to information, and broadly served to bring the situation alive, there was still scope for the creative writer. A pioneer of this form of the feuilleton was Mikhail Kol'tsov (1898-1942). Significantly, it was in this period that Zoshchenko made his literary debut. He was quick to seize upon and exploit the possibilities offered by this new form. In doing so he expanded its scope immeasurably. 
Let us examine the aspects of the feuilleton that Zoshchenko was to employ:

- Fact

Unlike a correspondent proper, the feuilleton writer selects one fact for the focus of the article. Leonid Ershov has stressed the feuilleton's factual basis:

расцвет фельетона в СССР в 20-е годы - свидетельство усиления документального, фахтического начала в литературе.

(...) такие жанры, хак очерк и фельетон, сделали многое для сближения литературы с жизнью ${ }^{24}$

The factual material upon which the feuilleton was based was very often the letters to the paper, particularly from worker and peasant correspondents:

Многие важные темы фельетонов подсказывает редакционная почта. Письма рабхоров и селькоров не только подсказывают темы, но и дают материалы для фельетонов (...) В некоторых газетах четыре пятых всех фельетонов имеют своим источником редакционную почту. ${ }^{25}$

The proximity of these two genres is such that the rubrics in which the letters of complaint are published can be seen as examples of the feuilleton, in that the letters are introduced and commented upon by a columnist. This effectively makes them feuilletons. ${ }^{26}$

\section{- Generalisation}

Having selected his fact the journalist had to ensure that it was understood in a certain context. He did this by reworking it artistically: 
В ряде случаев фельетонист создает условные диалоги, рисует сценки, которых на самом деле не было. Все это ему необходимо, чтобы раскрытть смысл развенчиваемого явления. ${ }^{27}$

The purpose of such literary reworking is to relate the incident at the basis of the feuilleton to larger social and political questions. In this way, the feuilleton performed an explanatory function that distinguished the Soviet press from other forms of journalism. ${ }^{28}$ However, this begs the question as to how far something can be artistically reworked before it ceases to be an example of journalism and becomes a work of literature. A tension between literature and journalism was inherent in the feuilleton form. Zoshchenko transplanted it into the skaz form, and transformed it into the expression of a philosophical problem.

\section{The rabkor and the Letter of Complaint}

Они беспомощны, комичны. Но вместе с тем они серьезны. (Pered voskhodom solntsa)

The facts reworked into the feuilletons were typically gleaned from letters written to the newspapers. A feature of the Soviet journalistic culture of the time was to encourage readers to participate in the press by writing to the papers about their own lives and conditions:

\footnotetext{
Чтобы у рабочего была своя газета, необходимо, чтобы сами рабочие писали про свои нужды и вопросы, чтобы сами рабочие были главными сотрудниками газеты. ${ }^{29}$
}

The aim of this activity was to criticise shortcomings in Soviet society with an view to improving them. The rabsel'kors or worker and peasant correspondents were 
central to this. As Jeffrey Brooks has argued, professional Soviet journalists had no incentive to criticise the regime's shortcomings, since they were themselves paid by the same State responsible for those shortcomings:

Critical commentary was reserved for unofficial local reporters, such as the worker and peasant correspondents, who were paid a few rubles for each accepted contribution. These occasional commentators lacked the autonomy, education and economic security to become an independent voice in Soviet society. ${ }^{30}$

These people wrote more or less systematically to a given newspaper and organised wall newspapers criticising shortcomings in their workplaces or conditions in the places where they lived with the aim of increasing production and improving the quality of life. ${ }^{31}$ The movement was officially encouraged in particular from 1923 when Pravda organised a conference of rabkors. ${ }^{32}$ During the NEP period, the Soviet government saw this as a vital means of improving production so as to industrialise the country. The satirical press was very much a part of this. In Krasnyi voron, the forerunner to Begemot, sections such as 'Otryvki iz rabochikh pisem' and 'Iashchik dlia zhalob' encouraged readers to perform the role of rabkors, and write in to complain about priests, nepmen and upravdoms and other perceived perpetrators of injustice at the behest of the columns:

Товарищи! Пишите обо всем в «Ящик для жалоб» Красного ворона. Будем сообща бороться с волокитой, нераспорядительностью, легкомыслием, взяточничеством, саботажем и отрищательными сторонами Нэпа. ${ }^{33}$

The readers responded enthusiastically and Zoshchenko was quick to recognise and seize upon the possibilities of this material. He used it as factual material and 
plots for his straight-forwardly journalistic feuilletons and for his short stories. He also drew on the material, in a less direct manner, by recreating their style, form, plots and the mentality of the letter-writers. An excellent example of such a reproduction of the style of letters of complaint and of their factual plots is Zoshchenko's most famous story, 'Bania', which was actually based on a number of letters of complaint. Zoshchenko refers to the process of writing 'Bania' in Pered voskhodom solntsa:

На моей подушке лежат письма в редакцию «Красной газеты». Это жалобы на банные непорядки. Эти письма мне дали, чтоб я написал фельетон.

Я просматриваю эти письма. Они беспомощны, хомичны. Но вместе с тем они серьезны. Еще бы! Речь идет о немаловажном житейском деле - о банях. ${ }^{34}$ (Pered voskhodom solntsa, SS III, p. 506).

The letter of complaint was a perfect form in which to combine the trivial and the important, since it was 'a theater in which the new Soviet public values were superimposed on the actualities of daily life'. ${ }^{35}$ But since Soviet public values did not always, or rather seldom matched up with the actualities of daily life the effect was typically that of a disparity. The given experience of daily life remained at odds with the interpretation of it. ${ }^{36}$

Further distortions resulted when Bol'shevik politics and political vocabulary were simplifed in the pursuit of a wider audience. This was true particularly of newspapers such as Rabochaia gazeta and Rabochaia Moskva:

The staff journalists simplified and abbreviated their presentation of Soviet values in the active sphere because of the subject matter and the character of the discussions. The semi-educated local correspondents and letter writers brought this public culture down to a still lower level when they tried to apply abstract values to specific issues. The transition was necessarily an imperfect one, since 
local correspondents were unable to replicate the public culture expressed by the staff journalists. ${ }^{37}$

Rabsel'kors in particular had a tendency to concentrate on one particular aspect rather than the whole picture. This was something which Gor kii highlighted:

Мрачный пессимизм [этих рабкоров] тем и объясняется, что они суживают свое внимание на плохом и хорошем в пределах именно своей фабрики, не зная или забывая о всей коллективной работе, творимой в Союзе Советов рабочим классом. ${ }^{38}$

This is an aspect of the rabkors that Fedor Raskol'nikov, writing in the proletarian literary journal $\mathrm{Na}$ postu, also highlights. He contrasts the rabkors' narrowness of vision with the broad sweep of the proletarian writer:

кругозор пролетарского писателя шире, чем у рабкора: рабкор отражает быт, нравы, экономические условия, норядки или непорядки своего завода, тогда хак пролетарский писатель отражает не только жизнь завода, даже не только жизнь рабочего класса в целом, но отражает жизнь, психологию и мировоззрение самых разнообразных классов, самых разнообразных общественных слоев, но разумеется, со своей пролетарсхой точки зрения. ${ }^{39}$

It would seem then that the relation between the abstract level of interpretation, of ideology, and that of the concrete and immediate experience, was a problem for the rabkor. Zoshchenko, as we have seen in the previous chapter, began to explore this question from his earliest surviving story, long before he started writing for the satirical press. In the letter of complaint, and in the figure of the rabkor, he found the perfect vehicle for the exploration of this tension. ${ }^{40}$ 
Moreover, the rabkors' letters were, of course, personalised narratives. In this they served as a blueprint for the narrator-participant skaz form that Zoshchenko was to make his own: the rabkor, like Zoshchenko's narrator does not use the impersonal narrative, and as a consequence cannot hide his self-interest behind a veneer of objectivity. As a result, the rabkor was potentially still more fruitful as a means of articulating Zoshchenko's other related perennial theme, the ubiquity of human material self-interest. The rabkor was typically somewhat upwardly mobile. ${ }^{41} \mathrm{He}$ often demanded the sacking of a specialist. All well and good, but he often also suggested that he himself be appointed in his place. Very often a motive of selfinterest was discernible behind the slogans about the good of the Soviet fatherland. ${ }^{42}$ The complaints themselves at times appear more sinister than public-spirited, and can perform the role of anonymous denunciations to the police.

\section{Rabkor as Meshchanin}

In Soviet terms a worker who did not conform to the idealisation of the working class, and who was concerned with his immediate self-interest and private pleasures rather than the good of the society, of the collective, of his class, was a meshchanin. This is not a social type, but a moral type: someone unable to rise above the everyday $[b y t]$, to concentrate upon the future, the goal, the essential [bytie]. ${ }^{43}$

In this it is similar (but opposite) to the Soviet definition of the proletarian. A proletarian was not just a member of a class, but also had to have proletarian classconsciousness. In other words, proletarian was a prescriptive not a descriptive term. ${ }^{44}$ Historians know this idealised worker of Soviet ideology better than they know the other worker whose world was one where drinking, brawling and cursing were prevalent. But that clean image is a distortion, such dissolute behaviour was in fact quite common: though drunkenness was seen as counter-revolutionary, the overwhelming majority of workers drank. ${ }^{45}$ This other worker's behaviour is, in Soviet terms, meshchanstvo. 
The interesting thing was that the non-politically conscious worker-meshchanin also regarded the Revolution as his victory, and was enthused with a new assertiveness and confidence. As Philips has argued, 'By the mid-1920s Russian workers had mastered revolutionary discourse and used it to further their own ends. ${ }^{, 46}$ This meant the justification of the pursuit of self-interest in the most banal spheres of existence, through the use of abstract political slogans, even as far as demanding the political right to go to the theatre or cinema when reelingly drunk. ${ }^{47}$ Similarly, workers paid lip-service to such abstractions ironically, while contravening their strictures: they might propose a toast to anti-alcohol campaigns or the cultural Revolution. ${ }^{48}$

The gap between the abstract slogan and the underlying motive of self-interest is something that Zoshchenko was able to observe in life, in the letters of complaint and rabkors' letters. It fitted his own view of the world, and he was able to find in the feuilleton form a particularly powerful means for the exploration of this tension. It should be stressed, however, that it is the tension between these two spheres that interests Zoshchenko. The balance of the Zoshchenko short story depends on us having as much sympathy for the striving towards ambitious interpretive abstraction as we have understanding of the underlying self-interest.

Another way in which Zoshchenko explored this tension was through the narrator's language.

\section{The Language of the Rabkor}

As well as providing factual material for the basis of his plots, and naturally fitting his vision of an irreconcilable conflict between the concrete sphere of existence and the abstract realm of ideologically informed interpretation, the letter of complaint also provided Zoshchenko with a rich vein of popular idiom with which to fill his note-book. In his memoirs, Chukovskii describes similar letters sent to Zoshchenko as 
корявые, дремучие, чаще всего дико безграмотные послания х Гаврилычу, полные воплей и жалоб беззахонно обижаемых людей. ${ }^{49}$

Zoshchenko was sincerely attracted to the new language and attempted to use it in his stories. Though written, this was the language of the recently literate and was far closer to the way in which people spoke than to the literary language. As such it brought to the stories the immediacy and energy of live speech, and can still be called skaz. At the same time it brought its defects. In particular, the problem that beset his stories was that the language was seen solely as a means of parody. Indeed, there is an inherent danger in using a language which is not the standard literary language, particularly the language of the people, in that it is likely to be seen as comic, as a parody. This is in part because of the traditional way in which the language of the people has been employed in literature. ${ }^{50}$

In order to avoid this unintended comic effect, when incorporating letters, magazines and journals of the time rewrote them. ${ }^{51}$ The same happens in modern day teenage magazines for example: letters in which the readers express themselves incompetently are rewritten so as not to detract from their emotional impact. ${ }^{52}$

Writers such as Mikhail Bulgakov and Zoshchenko himself were employed to rewrite these letters. ${ }^{53}$ The effect of this rewriting was that the language of literature, and even of journalism, did not resemble the language that was being spoken by the common people. Thus Zoshchenko, in Pis'ma k pisateliu (1929), was able to defend himself from the charge that he was corrupting the Russian language for cheap laughs by claiming to be reproducing the language, 'na kotorom seichas govorit i dumaet ulitsa' (Uvazhaemye grazhdane, p. 371). He claims to have done this, just as he claimed to have adopted journalistic forms, with the purpose of democratising literature:

Я сделал это (в маленьких рассказах) не ради курьезов и не для того, чтобы точнее котировать нашу жизнь. Я сделал это для того, чтобы 
заполнить хотя бы временно тот холоссальный разрыв, которьй произошел между литературой и улицей.

А говорю - временно, так как я и в самом деле пишу так временно и пародийно. (Uvazhaemye grazhdane, p. 371)

Zoshchenko sees the letters that he receives as confirmation that he was right as to how the street thinks and writes.

Zoshchenko then, in his short stories and feuilletons, reintroduces the actual language that the workers might have used if an average one became a writer, or attempted to become one. Having done this, he was beset by the problem the practice of editing and rewriting was introduced to overcome: only the ridiculous aspect of his narrator's language was perceived. His work was seen as parodic.

Insofar as we can perceive it through the process of rewriting and editing, the language of the rabkors seems to have been a strange hybrid. Raskol'nikov encourages rabkors to use a more rugged idiom than is standard literary practice:

\section{Рабкоры, приходящие в литературу, меньше всего должны делать попытки писать интеллитентским языком. Пусть они пишут так, как они привькли говорить. Пусть пишут тем язьком, который им дали рабочие массы. ${ }^{54}$}

The tone of entreaty is in part because, as Michael Gorham has shown in his study of the phenomenon of the rabkors, they tended to abandon their natural idiom in the attempt to master the language of journalistic cliché. This was a result of the strange position in which they found themselves: they were expected to act both as the organic voice of the people and as the politically active representatives of the Soviet state. The effect of mixing these languages was a bizarre hybrid, because the idiom of colloquial speech and that of political jargon did not complement each other. Instead both became deformed. Rather than conveying any message, the rabkor's language 
often drew attention to the contorted construction of his discourse. Gorham sees Zoshchenko's 'Obez'ianii iazyk' (1925) as typical of this hybrid language.

However, Gorham only sees the parodic aspect of this language: writer and reader can laugh at the narrator. In fact, Zoshchenko transforms this language into a linguistic analogue of the profound conflict of abstract interpretive system and particular experience. The highly concrete linguistic medium resists and disrupts the ideology it attempts to bear. The effect is not so much a laugh at the expense of the narrator, but despair at the impasse of the human condition.

In this section we have examined aspects of 1920 s journalism relevant to Zoshchenko's work. In particular, we have described two journalistic forms in detail: the feuilleton and the letter of complaint. We have also discussed the figure of the rabkor, in part because he is tied up with the letter of complaint phenomenon, but also because his language and mentality prefigure the language and mentality of Zoshchenko's character-narrators. Having established the journalistic context we can now show how Zoshchenko's work relates to it.

\section{iv) The Influence of Journalistic Forms on Zoshchenko}

Before introducing examples of Zoshchenko's use of journalistic forms, let us briefly summarise the emphatically journalistic elements in Zoshchenko's art, and contrast them with the properly fictional short story form:

\section{- Factual Basis}

The feuilleton is based on a true incident or fact, or what purports to be one, and demands that the reader believe that the figures in it are real and not fictional. ${ }^{55}$ This need not be the case with the short story. Zoshchenko habitually based not only his feuilletons, but also his short stories, on such factual sources. 


\section{- Immediate Topicality}

Immediate topicality is a further characteristic common to both the form of a Zoshchenko short story and that of a feuilleton. As Ershov has indicated, it is not normally a feature of the short story. ${ }^{56}$ In Zoshchenko's short stories though, the events are very commonly related to events of the day, after the manner of a feuilleton. ${ }^{57}$

\section{- Generalisation}

The 'large feuilleton' generalises and puts a single fact or incident in the context of a socially significant wider theme. ${ }^{58}$ This also functions as a way of ensuring that the reader interprets these events in the 'correct' manner. ${ }^{59}$

The combination of the generalised theme and the particular incident is a matter of artistic technique, which distinguishes the feuilleton from simple reporting, i.e. from journalism that presents itself as the simple transmission of facts. Ershov argues that this is what enabled the feuilleton to become a self-sufficient genre, no longer dependent on the press, but published separately in collections. ${ }^{60}$

Zoshchenko transforms this scheme, by relating the fact to a general theme which is irrelevant. The fake generalisation is often really the expression of the narrator's own interests. ${ }^{61}$ Zoshchenko's narrator, unlike that of a normal feuilleton, often expresses his opinions and makes generalisations incompetently, prompting us to supply a new interpretation of the event.

\section{- The Letter of Complaint Writer or rabkor}

Zoshchenko uses, stylises and parodies the letter of complaint writer and the figure of the rabkor. At times this figure becomes inseparable from that of the skaz character-narrator employed in stories that show little or no journalistic influence. 
With 'Pis'ma v redaktsiiu' (SS I, pp. 449-51), Zoshchenko first attempted to reproduce the letter of complaint form. As his first reproduction of journalistic forms, they are worth analysing, though they are not representative of his use of journalistic forms. In 'Pis'ma v redaktsiiu' Zoshchenko's intentions are overwhelmingly parodic. While simple parody was not typical of his later use of journalistic forms, it was generally the purpose of his use of $s k a z$ in this early period of his work, as I have shown above (in Chapter IV).

One indication of the parodic intention in these letters is that despite Zoshchenko's claims to the contrary, there seems here to be no genuine factual basis for these letters. Consequently, I propose to examine them as fictional parodies of the letter of complaint. ${ }^{62}$ There are a number of good reasons for seeing these letters as Zoshchenko's fictional creations. First of all, the names of the letter writers are typical of Zoshchenko. The first letter, 'Prelesti NEPa' is by Semen Kaplunov, the same initials as 'Semen Kurochkin', a favourite pseudonym of Zoshchenko at this time. The second letter is signed 'Kontorshchik Iv. Lermontov', which follows the pattern of using the surname of a great writer parodically combined with a rustic sounding first name, that Zoshchenko repeated in 'Otkrytoe pis'mo' (1924) (Uvazhaemye grazhdane, pp. 227-29), where one of the signatories is Vasia Pushkin.

The complaints touch on common grievances: for example complaints about public transport were common, not only in Zoshchenko's work. The first letter, 'Prelesti NEPa' complains that the bourgeois passengers have been elbowing and pushing. The letter writer has even had his foot stepped on. However, the theme of having one's foot stepped on is a theme particular to Zoshchenko. ${ }^{63}$ Moreover, the claim that the people causing the trouble are bourgeois is reminiscent of the complaints made on behalf of Vasia Rastopyrkin in another of Zoshchenko's short stories, 'Meshchanskii uklon' (1926) (SS I, pp. 360-62). The use of 'mankirovat", a foreign loan word, is not typical of Zoshchenko's narrators except when referring to foreigners or foreign countries. However, it does suggest a tendency to bluff and to be too clever for their own good which is typical of his narrators. The most significant 
aspect of this and the other letters is the excessive attention that they pay to trivial aspects of life. The letter writers seethe with righteous indignation over complete trifles.

The second letter, 'Vnimaniiu militsii' is a complaint by office worker Iv[an] Lermontov, who was travelling on a steamboat when he was spat at from a bridge. The offending phlegm landed unnoticed on a 'former' lady's hat. Lermontov, the letter writer, demanded that the Finnish captain stop the boat so that he could catch the 'expectorating hooligan', but the Finn refused.

This letter begins with a generalisation after the manner of a feuilleton and Lermontov uses a general category to refer to a single steamboat: 'legkoe parokhodstvo' rather than the more appropriate term for a steamboat, 'parokhod'. As with Zoshchenko's later uses of this device, there is a disparity between the incident and the generalisation. However, where in later uses of the feuilleton form the incident often disproves the generalisation based upon it, here the satiric charge is simply that this is such a trivial matter, and not a generalised phenomenon at all. The narrator is clearly a fool, and an old world fool with antiquated manners at that. As such he is the butt of the humour, as is the rule with 'former' people in Zoshchenko's work of this period.

Here the simply absurd element of the situation is also important. Ivan Lermontov demands that the captain stop the boat. This is in itself ridiculous, since boats cannot simply be stopped as he demands. Moreover, he seems to be the only person who takes any notice of the incident. Even the woman who was hit by the spit does not notice. The letter ends with the demand that steamboat passengers be protected from spitting, itself an absurd demand that would be extremely hard to realise.

This same pattern of the demand for an absurd measure to be taken is repeated in 'Glas vopiiushchego' (the third letter). Here a complaint about the price of coffins ends with a demand that a department be set up where every employee [sluzhashchii] can buy themselves a coffin. 
The same pattern of complaints based upon incidents that occurred to the letter writers but are not revealing of any general phenomenon repeats itself throughout these letters. In 'Teatral'naia zhizn"' (the fifth letter), the letter writer suggests that theatre seating arrangements be ordered according to each given spectator's height. This demand is a result of his being seated behind a tall woman at a recent visit to the theatre. This letter as well as 'Baron' (the fourth letter) and 'Panama' (the sixth letter) are full of the class resentment of professionals such as actors, doctors and engineers. All of the letter writers are 'former' people, and like the peasants and priests in the stories of this period, they are simply to be laughed at; there is no mixture of sympathies.

The narrators of these three letters use language that is close to that of Zoshchenko's later stories, particularly the narrator of 'Panama', who refers to the engineer as 'sobachii nos'. This is in contrast to the narrators of 'Vnimaniiu militsii', 'Glas vopiiushchego' and 'Golos prokhozhego' (the seventh letter) who express themselves in the more formal and bureaucratic language typical of their professions.

These letters all parody the absurdly specific and trivial nature of complaints by basing them upon an incident that the narrator experienced, but that is not at all typical or relevant to society as a whole. Sometimes they are motivated by a reference to the general situation that is unconvincing. In such complaints Zoshchenko is evidently exploring the strange phenomenon of the use of the complaint form by people who believe that their own interests are completely identical with those of the society. This obvious paradox in a society in which collective interests were meant to prevail over personal ones apparently attracted him. Here the class background of the letter writers discredits their complaints and their personal experience. In his later stories, the letter writers' class does not discredit their complaints and readers are left to adjudicate between the claims of personal experience and those of ideological abstraction. The imbalance between the personal experience of an incident and the generalisation is accentuated by the writers' constant appeals for the readers' sympathy. This appeal for sympathy by the narrator is an element very proper to the 
letter form's directness. Although here other factors mean that we disregard the appeals, this is another element of the letter of complaint form that Zoshchenko was to incorporate in his short stories through the use of a skaz narrator.

Though 'Pis'ma v redaktsiiu' prefigure Zoshchenko's later use of journalistic forms in significant ways, they also stand in stark contrast to the ambivalence of the later work in the unmitigatedly satirical tone of their parody. Nevertheless, it is significant that these letters were only Zoshchenko's second submission to the satirical press. He ended the 1920s with the publication of Pis'ma k pisateliu, a collection of letters that he edited. This dependence on the documentary form, and on letters, underpins his work throughout the 1920s.

\section{Letters as Factual Sources for Zoshchenko's Feuilleton-Stories}

The feuilleton, as we have seen, is based on factual sources, usually a letter to the magazine or newspaper. The same is true of Zoshchenko's short stories. It would be almost impossible to recover all of those sources, reckoned to lie behind over a third of his stories. Nevertheless, it would be helpful to compare the sources with the final versions of the stories in order to see quite how and how far Zoshchenko reworked them. I propose to look at the documentary sources of a few stories, including those for one of Zoshchenko's most famous works, 'Bania'. ${ }^{64}$

\section{'Bania' (1925)}

'Bania', which was first published in the satirical magazine Begemot in 1925, is a good example of Zoshchenko's adaptation of the feuilleton form to that of the short story. ${ }^{65}$ It is also a good and revealing example of Zoshchenko's use of readers' correspondence: important elements of the story are taken from letters published in the satirical press from 1923 to 1925 . 'Bania' also typifies Zoshchenko's ambivalent attitude to the feuilleton form. He relies on certain of its typical features of generalisation, immediacy and a factual basis. But at the same time he plays with and even ridicules these features. The story's ambivalent tone is an excellent example of 
the mixture of sincerity demanding the reader's sympathy expressed in a parodic language. In order to help the reader follow this close reading of 'Bania', I have decided to reproduce the original magazine published version of the story:

\section{BAHЯ}

Говорят, граждане, в Америке бани очень отличные.

Туда, например, гражданин придет, скинет белье в особый ящик и пойдет себе мыться. Беспокоиться даже не будет - мол, хража или пропажа, номерка даже не возьмет.

Ну, может, иной беспокойньй американец и скажет банщику:

- Гут бай, дескать, присмотри.

Только и всего.

Помоется этот американец, назад придет, а ему чистое белье подают стираное и глаженое. Портянки небось белее снега. Подштанники зашиты, залатаны. Житьитко!

А у нас бани тоже ничего. Но хуже. Хотя тоже мыться можно.

У нас только с номерками беда. Прошлую субботу я пошел в баню (не ехать же, думаю, в Америку), - дают два номерка. Один за белье, другой за пальто с шапкой.

А голому человеку куда номерки деть? Прямо сказать - некуда.

Карманов нету. Кругом - живот да ноги. Грех один с номерками. К бороде не привяжешь.

Ну, привязал я $\mathbf{X}$ ногам но номерку, чтоб не враз потерять. Вошел в баню.

Номерки теперича по ногам хлопают. Ходить скучно. А ходить надо. Потому шайку надо. Без шайки какое ж мытье? Грех один. 
Ищу шайку. Гляжу, один гражданин в трех шайхах моется. В одной стоит, в другой башку мылит, а третью левой рухой придерживает, чтоб не сперли.

Потянул я третью шайку, хотел, между прочим, ее себе взять, а гражданин не выпущает.

- Ты что ж это, говорит, чужие шайки воруешъ? Ках ляпну тебе шайкой между глаз - пе зарадуешься.

Я говорю:

- Не царский, говорю, режим шайками ляпать. Эгоизм, говорю, хакой. Надо же, говорю, и другим помыться. Не в театре, говорю.

А он задом повернулся и моется.

«Не стоять же, думаю, над его душой. Теперича, думаю, он нарочно три дня будет мыться».

Пошел дальше.

Через час гляжу, хахой-то дядя зазевался, выпустил из рух шайку. 3а мылом нагнулся или замечтался - не знаю. А только тую шайку я взял себе.

Теперича и шайка есть, а сесть негде. А стоя мыться - какое же мытье? Грех один.

Хорошо. Стою стоя, держу шайку в руке, моюсь.

А хругом-то, батюшки-светы, стирка самосильно идет. Один штаны моет, другой подштанники трет, третий еще что-то хрутит. Только, скажем, вымылся - опять грязный. Брызжут дьяволы. И шум такой стоит от стирки - мыться неохота. Не слышишь, куда мыло трешь. Грех один.

«Ну их, думаю, в болото. Дома домоюсь».

Иду в предбанник. Выдают на номер белье. Гляжу - все мое, штаны не мои.

- Граждане, говорю. На моих тут дырха была. А на этих эвон где.

А банщик говорит: 
- Мы, говорит, за дырками не приставлены. Не в театре, говорит.

Хорошо. Надеваю эти штаны, иду за пальтом. Пальто не выдают номерок требуют. А номерок на ноге забытый. Раздеваться надо. Снял штаны, ищу номерох - нету номерха. Веревка тут, на ноге, а бумажхи нет. Смылась бумажха.

Подаю банщику веревку - не хочет.

- По веревке, говорит, не выдаю. Это, говорит, каждый гражданин настрижет веревок - польт не напасешья. Обожди, говорит, хогда публика разойдется - выдам, хакое останется.

Я говорю:

- Братишечка, а вдруг да дрянь останется? Не в театре же, говорю.

Выдай, говорю, по приметам. Один, говорю, харман рваный, другого нету. что касаемо пуговиц, то, говорю, верхняя есть, нижних же не предвидится.

Все-таки выдал. И веревки не взял.

Оделся я, вышел на улицу. Вдруг вспомнил: мыло забыл.

Вернулся снова. В пальто не впущают.

- Раздевайтесь, говорят.

Я говорю:

- Я граждане, не могу в третий раз раздеваться. Не в театре, говорю.

Выдайте тогда хоть стоимость мыла.

Не дают.

Не дают - не надо. Пошел без мыла.

Конечно, читатель привыхший $\mathbf{x}$ формальностям может полюбопытствует: какая, дескать, это баня? Где она? Адрес?

Какая баня? Обыкновеннная. Которая в гривенник.

А на какой улице - не скажу. Себе дороже. Потому после придешь стукнут тебя шайхой по балде - глядишь и нету сознательного, вдумчивого гражданина. ${ }^{66}$ 
As we can see in the extract from Pered voskhodom solntsa reproduced above (on page 144), the story began as a feuilleton. Elsewhere Zoshchenko refers to 'Bania' as a story: it has always been classified as a short story and is termed such in every edition of Zoshchenko's works. ${ }^{67}$ Its initial designation as a feuilleton is revealing as to the immense overlap of these forms in Zoshchenko's work. ${ }^{68}$ The sources for the story can be found, albeit with an appended commentary, on the complaint pages of Krasnyi voron. In a letter to Krasnyi voron in March 1923, there is a complaint about a public bathhouse in which it is impossible to get washed:

\section{ВМЕСТО БАНИ - КОНЮШНЯ}

\section{В Василеостровских банях (9-я линия, 16), в раздевальнях устроена} парикмахерская, которая притом, ничем не огорожена. Помещение небольшое, и вымывшимся посетителям, после раздевальни, приходится хоть снова итти в баню...

Similar incidents involving bathhouses in which it is impossible to get washed are repeated twice more on the reader's pages subsequent to the publication of 'Bania' in March 1925 (Begemot, No. 11, 1925 \& No. 49 1925). This becomes something of an urban myth. In the actual story 'Bania', (SS, I, pp. 278-79), the narrator repeats a rumour he has heard about the spotless cleanliness of American bathhouses. ${ }^{70}$ Soviet ones are also all right, he says, except worse, but you can wash in them: 'A u nas bani tozhe nichego. No khuzhe. Khotia tozhe myt'sia mozhno'(p. 278). The rest of the story shows that this is in fact not the case, at least not for the narrator in that apparently typical bathhouse. Ultimately the title of the story becomes ironic, since a bathhouse in which it is impossible to wash is not really a bathhouse at all. ${ }^{71}$ This is directly parallelled in this feuilleton, where it is called a stable.

In 'Bania', the narrator is unable to wash because other people are washing clothes and splashing him with their dirty water, so he decides to go home and wash. This element of the story appears to be even more directly derived from a letter of 
complaint. In Krasnyi voron, No. 3, 1924, someone complains about people washing clothes in the bathhouse. Here, there is a contrast with the columnist's response to the letter in the first source. In that case, the columnist's comments were full of sympathy, though humour was also derived from the sheer ridiculousness of the situation of a bathhouse in which it is impossible to get clean. However, in the second source the columnist treats the incident in a completely humorous manner, laughing at the reader for writing to the paper and not sorting the matter out for himself: 'Sami, nebos', boites', oshpariat, a nas posylaete. Dudki!' The columnist concludes that the person who wrote the letter was too scared of being shouted at to go and complain to the people washing their clothes and that is why he wrote to Krasnyi voron, rather than immediately sorting the matter out for himself. This theme is also developed in the story, where after being threatened by someone hogging three basins, the narrator does not even think of complaining to the people washing their clothes. In the version of 'Bania' first published in Begemot in 1925, the narrator refuses to name the exact location of the bathhouse, for fear that he will be assaulted the next time he visits it. This appears to be an oblique reference to the widespread violence against Rabkors. Typically, they were threatened with violence by those they criticised. In 1922 a rabkor called Spiridonov was murdered; in 1924 eight rabkors were killed. All of these deaths were attributed to retribution by 'class enemies'. Gorham notes that persecution was so widespread that the rabsel'kor trade paper had a rubric devoted to this subject. $^{72}$

The contrasting responses of the journalist commenting on the article to the letters are another way in which they seem to prefigure 'Bania' the story. In this instance they anticipate the mixed reaction that 'Bania' the story arouses in readers: we laugh at the narrator for his fantasies about American bathhouses, his attempts to defend Soviet bathhouses, his lack of courage, his clichés, and the sheer ridiculousness of the situation, but feel sympathy for his humiliation at the hands of the attendants and the other patrons. 
Another major element of the story, the problem with cloakroom tickets, appears to derive from a previous letter of complaint to Krasnyi voron in 1924:

\section{БАННЫЙ ВОПРОС}

Один товарищ очень обиделся на бани. Дают, взаймен взятого на хранилище белья, номерки. Вот в них-то и сидит самая язва. Сами, товарищи, судите:

«Номер дается на веревочке, веревочка от мохроты зачинила, вследствие чего посетитель не может номер куда-либо на себя привязать. А беря номер с длинной веревочкой и вешая его на себе на шею, рискуешь получить какую-либо болезнь... А если не брать номер, а только запомнить - можно, а тем временем специальные жулики подкарауливают, где белье без номера и стараются такие получить.»

Словом, как нн кинь - все клин, ках ни брось - все бабке в бровь! С номерами - болезнь, без номера - жулики. Не баня, а - западня! Куда деваться?... Впрочем, если очень не задумываться над банным вопросом, так оно, пожалуй не так уж страшно? Может, и вовсе не страшно, а то - и совсем пустяки? Вернее - плевое дело даже! Так, от скуки поговорили и довольно! ${ }^{73}$

Here the fear that someone else might get the patron's clothes and the impossibility of attaching the ticket to oneself are elements that the story reworks. Moreover, here once more the bathhouse is said to be something other than a bathhouse: 'Ne bania, a - zapadnia.' In the commentary to the letter the contrasting attitudes of the first two sources are combined, so that the story shows sympathy before lightheartedly condemning the incident as trivial, a device that Zoshchenko was to employ in a number of later stories.

Thus we see that Zoshchenko almost certainly worked by lifting factual accounts from various different letters sent to, in this instance, Krasnyi voron, and 
incorporating them into a story. However, the short story 'Bania' is not based on a single letter. The various elements of the three sources are further transformed by making a narrator experience these difficulties at first hand and narrate them as a skaz narrator-participant. Where the columnist commenting on the letters, particularly with the last two letters, treats the difficulties experienced by the reader as a subject for humour, regarding them as trivial or ridiculous, Zoshchenko makes the narrator of the story the actual person experiencing these difficulties. This is a dramatisation of the situation in line with the nature of a feuilleton. However, through his use of a particular type of skaz narrator, Zoshchenko achieves an unusual degree of ambivalence not typical of the feuilleton.

In 'Bania', the use of a skaz narrator-participant renders the experience of humiliation suffered by the character more immediate. There is no objective narrator to interpose between the character who experiences the suffering and the narration of that suffering. The narrator's experiences become the central focus of the story, and their vivid evocation makes the appeal to our sympathy all the more direct. Greater directness is also achieved in the language itself. As we have seen in the discussion of $s k a z$, narration in a language more typical of the character than of the standard narrator is one of the defining characteristics of skaz. Here Zoshchenko employs such narration. The syntax also conforms to his prescriptions for the literary language in its brevity and use of ellipsis. For example, "Ne tsarskii rezhim, shaikami liapat" suppresses logical links such as 'chtoby mozhno bylo', to create a more direct and expressive language. The short sentences, often of no more than one word, also typify Zoshchenko's attempt to compress the language and enliven syntax. This is a clever use of the skaz form as sympathetic stylisation.

At the same time this unmediated appeal to our sympathies is undermined. The events narrated comment upon the narrator's opinions. For example, after waiting for an hour he steals someone else's basin. Though he condemns someone else for their egoism in using three basins, while he has none, he is not at all above inflicting the same suffering on someone else. Moreover, the very language that produces skaz and 
its direct appeal also undermines that appeal through the use of cliché, verbal tic, tautology, slang and grammatical error. These exaggeratedly substandard usages tend to render the narrator's language parodic and increase our distance from him, as does the humour of the situation. The contradictory and ambivalent attitudes that were present in the treatment of the theme in the sources from the reader's letters page are made still more intractable in the story.

As we have seen, Zoshchenko himself referred to 'Bania' as both a story and a feuilleton. The final version cleverly parodies the feuilleton form. The narrator begins and ends the story with an attempt to link his experiences to a wider context. This attempt to generalise from the specific incident is a generic characteristic of the feuilleton. The story's narrator relates the incident to some gossip he has heard about the high standards of bathhouses in America. This piece of gossip seems to mix up the description of a bathhouse with those of a laundry, a dry cleaner's and a clothes repairs service. This fantastic exaggeration, born of the awful state of Soviet bathhouses, suggests the narrator's inability to place his experiences within an appropriate context. He fails to generalise convincingly from the particular in the way that a good feuilleton should. The narrator then compares Soviet bathhouses unfavourably with those in America, but in their defence claims that you can wash in them. Even this most modest of generalisations is unstable and is invalidated by the experiences that are narrated in the story. The narrator finds it impossible to wash. He is prevented from doing so by people washing their clothes. ${ }^{74}$

However, the claim is that it is possible to get washed in Soviet bathhouses. On the narrator's own experience of a typical bathhouse, this would seem not to be the case, despite his considerable efforts. Yet the story does show some other people washing, and thus produces some evidence that it is possible to get washed. The generalisation is invalidated by the narrator's own experience, but not by what he sees of other people's experience. Yet individual experience is itself an unstable sphere: even the narrator's use of the tautological construction 'poidet sebe myt'sia' suggests this by repeating the reference to the self. 
As readers we are left to decide whether to trust the narrator's experience, or his generalisation that it is possible to wash in Soviet bathhouses. Neither quite tells the whole truth. What truth there is can be understood as a tension between the conflicting accounts of the incident. This is an example of how Zoshchenko turns generalisation and concrete factual experience, the basis of the feuilleton, into a philosophical conflict between the claims of concrete existence and those of abstract ideology.

The story has the journalistic immediacy of a feuilleton. The incident supposedly occurred 'last Saturday'. Zoshchenko here parodies this characteristic by making the narrator's immediacy, his proximity in time, and his acquaintance with the bathhouse all factors tending to mar the account rather than improve it. This narrator might more properly have placed his experiences in an appropriate context if he was not writing so soon after the events and if he researched the actual conditions of American bathhouses. Nevertheless, the immediacy of the first person narrative still has a certain direct appeal which is difficult to disregard, for all the narrator's inconsistencies and errors.

Similarly, the ending parodies the feuilleton's characteristic of being based on a particular incident directly experienced by the correspondent. As Ershov has indicated, the Soviet feuilleton typically revealed the exact identity of the people implicated and the exact address of any enterprises or institutions involved in the incident. $^{75}$ The motive behind this was to hold those concerned up to ridicule with the aim of reforming them, in accordance with the didactic aims of Soviet satire. The original 1925 Begemot version of the ending of 'Bania' parodies that formula by anticipating the reader's demand for the exact address of the bathhouse in the last six lines of the story (as it is reproduced above). Here, instead of giving the address, the narrator simply claims that it is a normal bathhouse. The reason for this is revealed in the last sentence. He does not give the exact address for fear of reprisal. Ultimately then, the narrator is unable to do what the feuilleton should do, i.e. reveal the identity of the objects of criticism, because he is in too immediate a relation with them. He 
avoids doing this by giving a vague generalisation. Zoshchenko here plays off the various elements of the feuilleton against each other. The narrator's immediacy, far from guaranteeing relevance, leads to a distortion of the importance of the incident and to the narrator's refusal to name the object of the criticism. Generalisation here, rather than furnishing the incident with an appropriate context, serves as a way of muting the effect of the satire.

In keeping with the critical position that sees Zoshchenko as satirising his narrator, Starkov argues that the discrepancy between the narrator's generalisations and the information we glean from his account is Zoshchenko's way of discrediting and parodying the narrator. He calls this the 'irony of the plot' [siuzhetnaia ironiia]. ${ }^{76}$ Certainly untrustworthy narration creates a distance indicating that the narrator and Zoshchenko's own position are not identical. However, as we have seen, this distance is not maintained evenly, and Zoshchenko's intention is not solely to parody his narrator. Rather, the elements of the feuilleton form are deployed in the earnest pursuit of new, easily consumed literary forms and at the same time for the purposes of parody. The language of Zoshchenko's narrator accomplishes the author's goal of bringing the literary language closer to the language of conversation and also parodies such language. The use of the skaz form renders the narrator's experiences more immediate, but it also suggests that this immediacy distorts the importance of those experiences. These ambiguities are unresolved. Zoshchenko's own position cannot be derived simply by inverting the narrator's own appraisal of events. The irony is not binary, but a far less predictable interplay of parody and stylisation, of sympathy and hostility.

\section{'Obez'ianii iazyk' (1925)}

Zoshchenko did not always combine so many elements from different letters into the one story. Sometimes the stories appear to have been developed from an incident described in a single reader's letter. Such a relation between letter and final product is more typical in feuilletons. 'Obez'ianii iazyk' is an example of a story that appears to 
be based on a single incident (SS I, pp. 264-66). The story tells of a meeting at which the narrator overhears two men talking incomprehensible gibberish composed of foreign loan words. The theme was treated in a reader's letter published in the ' $\mathrm{Na}$ prieme u Begemota' column earlier that year, in which the correspondent complained about foreign loan words being used indiscriminately in meetings:

\section{ЧИСТОТА ЯЗЗІКА}

На еженедельных общерайонных собраниях работников библиотечного дела Волдарского района

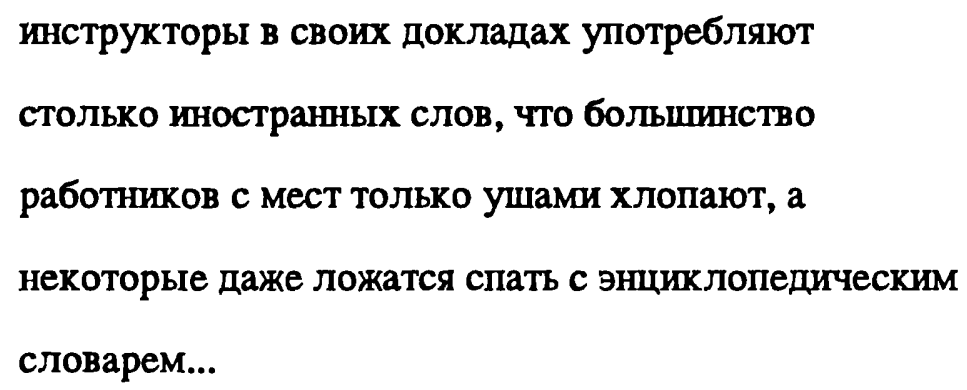

Резолюция Бегемота. Информирую инструхторов об абсурдности quasiинтеллектуальной элоквенция в конгрегациях локальных колаборантов. Слушали? То-то! ${ }^{77}$

Although it might be argued that this is a generalised phenomenon, the coincidence of themes is extremely, indeed uncannily, close. Moreover, the story and the letter even employ the same expression for 'to look dumb' [khlopat' ushami]. Like 'Bania', 'Obez'ianii iazyk', heightens the dramatic effect of the incident by telling the story from the point of view of someone involved in the incident, in this case one of the people who do not understand the foreign words. One extra comic touch that the story adds to the original reader's letter is that the two men using all the foreign loan words themselves do not understand them, but pretend that they do. Their pretence goes so far as to argue in words that they clearly do not understand: 
- Вот вы, товарищ, небось не одобряете эти пленарные заседания... А мне хак-то они ближе. Все как-то, знаете ли, прямо скажу, последнее время отношусь довольно перманентно $\mathrm{x}$ этим собраниям. Тах, знаете ли, индустрия из пустого в порожнее.

- Не всегда это, возразил первый. - Если, хонечно, посмотреть с точки зрения. Вступить, так сказать, на точку зрения и оттеда, с точки зрения, то - да, индустрия хонкретно.

(SS I, p. 265)

They even get annoyed with each other as if there was a point of principle at stake in the argument. They are of course the main objects of satire in this story. However, here the narrator is also satirised, as is the feuilleton form that he attempts to use. In attempting to place the incident within a general context, as the narrator of a feuilleton should, he shows himself to be as guilty as the people he has overheard of arguing about that of which he knows nothing. He compares Russian with French, arguing that the problem with Russian is that there are so many foreign words in it:

Ну взять французскую речь. Все хорошо и понятно. Кескесе, мерси, комси - все, обратите ваше внимание, чисто францзуские, натуральные, понятные слова.

(SS I, p. 264)

However, he clearly does not know French: if he did he would realise that the two men are talking pretentious nonsense. Hence he is certainly not in a position to say that everything in that language is easy to understand. Moreover, he does not admit that he gets nothing of what the other characters say, but claims that he 'understood their conversation with difficulty'. There is even a suggestion that he is more annoyed by the fact that he was made to look stupid than concerned by the state of the Russian language. 
In a formula that Zoshchenko exploited on a number of occasions, the person criticising is himself exposed as guilty of similar failings, and incapable of upholding a superior moral standard. Examples of such stories are 'Butylka' (1927) (SS I p. 390) in which the narrator stands by and observes people's lack of public spiritedness in not cleaning up a broken bottle, though he himself is guilty of the same failing; 'Sobachii niukh' (1924) (SS I, pp. 181-82), in which a sniffer-dog is brought in to track down a theft and ends up forcing confessions of petty crime from everyone: the victim of the theft, the militia dog-handler and even the narrator; ${ }^{78}$ 'Rech' o vziatke' (1923) (Uvazhaemye grazhdane, pp. 198-99), 'Pisatel"' (1923) (SS I, pp. 155-57) and 'Chestnyi grazhdanin' (1923) (SS I pp. 161- 63), in which those who set out intending to denounce others end up denouncing themselves. The implication in such stories is that there is no infallible position from which to criticise, since all vantage points are potentially corrupted by self-interest. This is yet another manifestation of Zoshchenko's vision of the competing claims of concrete self-interest and abstraction, where abstraction here is the neutral position of the observer making sense of events.

'Obez'ianii iazyk' is another instance where Zoshchenko takes documentary material and produces a short story close to the feuilleton form. However, here the introduction of a special type of skaz narrator serves to parody the feuilleton form and satirise the criticisms of the narrator. This is something that the writer has added: whereas in the reader's letter, those using foreign loan words are the sole objects of satire, in his story, Zoshchenko satirises both those who use that language and the person who does not understand such language.

This additional twist in perspective also sharply differentiates 'Obez'ianii iazyk' from 'Bania', in that it undermines all sympathy for the narrator, rather than problematising it as in the earlier story. This is not just satire or parody, but metasatire: the object is satirised, but so is the satiriser. This dynamic form of satire leaves us feeling uncomfortable: maybe we too are as hypocritical as the narrator. Whereas in 'Bania' we were challenged to decide whether to trust existence or ideology, here we are challenged to ask ourselves on what basis we criticise. Zoshchenko in this use 
of narrative technique shows himself an heir to the mantle of Gogol', in asking us whether we in fact have the right to laugh at those satirised: are we ourselves (present company of course excluded) not guilty of the same pretentious use of language, and of pretending to understand that which is really beyond our grasp?

We may wonder where the author's sympathies lie. Yet even here there is something suspicious about the notion that Zoshchenko's own position can be derived by inverting the views or language of those satirised. In the matter of language, the evidence from Zoshchenko's articles is contradictory. He believed a clear, simple language to be best suited to the needs of the age: 'nuzhno pisat' iasno, kratko i so vsei vozmozhnoi prostotoi...'(Uvazhaemye grazhdane, p. 589). However, he also believed that the language of literature should be closer to the way in which people actually speak. The absence of a normative language, and the lack of a clearly defined normative point of view is central to Zoshchenko's vision of satire. If we read Zoshchenko's use of skaz as a deviation from an implicitly understood linguistic norm, i.e. if we read it as satire or parody in the sense intended by many theorisations of skaz and by influential interpretations of Zoshchenko, such as that of Kreps, then we congratulate ourselves for having the correct point of view and laugh at the narrator for his stupidity. To do this is to simplify it, sanitise it and deaden its blows. Such interpretations resolve Zoshchenko's contradictions and confine Zoshchenko's universal comic genius to the narrow context of the 1920s and to the Soviet Union. To do so is a grave error. Zoshchenko's satire continues to pose awkward questions of us. It is relevant as long as we are hypocritical and stupid.

\section{'Shapka' (1927)}

In 1923, in 'Kholodil'nik', a column in the journal Drezina, an incident is reported that served as the basis for one of Zoshchenko's weaker stories, 'Shapka' (SS I, pp. 408-09): 


\section{Urбqe roнxu}

Ехал машинист Чернышев с поездом 113 по Рязансхой дорожке. Доехал до какого-то полустанка, - вспомнил: шапку потерял. А где потерял - не Помнит.

Повернули машину назад в ходу. В роще поискал - нету шапки. Попер дальше. Смотрит, шапка на хосогоре лежит у разъезда «Спасское». ${ }^{79}$

In 'Shapka' Zoshchenko recounts the same incident of an engine driver losing his hat and putting the train into reverse in order to find it. Here though, he presents it as the sort of thing that used to occur in 1918 and 1919, and makes it an index of how far everything has progressed in the ten years since the Revolution.

This example differs significantly from the two previous ones, where the factual basis serves to enhance the topicality and relevance of the story. Here the original account appeared four years before being incorporated into an article. It was published in Drezina, which was printed by the railwaymen's printing house, Gudok. In the reworking of the incident it is narrated by a former railway worker. His attempts to show how far things have progressed in ten years serve as the feuilletonstyle generalisation that starts off the story. However, the incident is not particularly revealing of the typical conditions on the railways in the first few years after the Revolution. It is more of an unusual incident that the narrator relates, not because of its importance as such, but because it happened to him. In this respect, it is a good example of Zoshchenko's narrator's incapacity to determine what is of historical importance or general interest and what is simply an amusing or unpleasant incident that occurred to him. The feuilleton form, parodied by the introduction of a skaz narrator, is the ideal form for this confusion as to the general and particular, the significant and the insignificant: the abstract and the concrete. A similar worm's eye view of history is presented in 'Zhertva revoliutsii' (1923) (SS I, pp. 168-170) and 'Istoricheskii rasskaz' (1924) (SS I, p. 210). 
The narrator's distorted understanding of historical progress is parodied, but the irony does not stop there. The image of the train is one with many resonances in the Soviet context, and was often used as a symbol of the Revolution. The story seems to imply a certain nostalgia for the ad hoc mentality expressed in the 1919 incident. It may only be a fur hat, but in Zoshchenko's world such items as galoshes, hats and boots take on vital importance and the essential drama of human existence is played out in a bathhouse, a buffet or a kitchen. There is something endearing in the engine driver getting the passengers to help him look for his hat. It suggests that people had a more caring attitude. The last lines of the story tell us that such things cannot happen now, but there is more than a little note of ambiguity in this conclusion:

\section{А теперь не только шапку - пассажира сдунет, и то остановка не более одной минуты.}

Потому - время дорого. Надо ехать. (SS I, p. 409)

The fact that trains now will not stop longer than a minute even when a person is blown off is revealing as to the lack of importance of the individual, and of the insignificant status of the particular incident in the new, organised Soviet society. This may not and indeed almost certainly does not correspond to any historical reality: respect for the individual was hardly the defining characteristic of the first years after the Revolution. Part of the irony in the choice of this episode is that it is not typical of the historical epoch. The historical situation is simply a frame in which the writer opposes the abstract notion of purposeful movement and progress, and the infinitesimal individual requirements of the person who has lost a hat. This person and the lost hat become a symbol for the individual and fragmentary. Zoshchenko, even in this apparently simple story, achieves the sort of ambivalence we saw in 'Bania' by making the incident a trivial index of the progress of the Revolution and at the same time an indication that this progress has been achieved at the cost of an attentive attitude to individual needs. 
'Krizis' (1925)

A 1923 letter from a rabkor to Drezina seems to have served as the genesis of the story, 'Krizis' (SS I, pp. 320-22):

\footnotetext{
Вхожу в строеньице с надписью: «для мужчин»,- пишет рабхор 189, -и нахожу там... квартиру. Жена служащего стоит у табуретки и лепит на ней вареники. Оказывается, здесь уже более 2-х месящев живет станционньй сторож, он - же ламповщик и кубогрей. А в полагающейся ему квартире благодушествует кто-то из «сохращенных». ${ }^{80}$
}

The story repeats the idea of people living in the most unlikely places, there a bathroom, in the letter, a public toilet. Zoshchenko's story is told by a narratorparticipant, which should make the experience of hardship all the more direct. However, this narrator is an optimist whose complaints are presented almost as afterthoughts. Indeed the description of how bad conditions are now appears almost as a qualification to his breathless fantasies about the building of new housing that have been aroused in him by the sight of bricks being transported. Moreover, despite the constant deterioration of his situation, he attempts to carry on and look on the bright side of life. These optimistic reveries function as the generalisation to which the story is the illustration. However, as we have seen with other examples, there is a discrepancy between the two. The extent of the housing crisis as depicted in the story in fact suggests that it will take more than 20 years to solve. All the cheerfulness in the world will not make a bathroom, and still more a bath, habitable. The relation between the incident and the narrator's interpretation of it and connecting of it with a general theme is that the latter are optimistic fantasies prompted by the unbearable nature of the present crisis, like the narrator's image of American bathhouses in 'Bania'. But at the same time there is something admirable in the obdurate nature of that belief. As with 'Bania', the fine balance and true force of the story depends on 
our sympathising with the optimistic belief whilst also recognising that the present incident and the logic of human experience in general threaten to undermine it.

\section{Further Influence of Satirical Forms}

\section{'Amerikanskaia reklama' (1926)}

A further example of the close relationship between the journalistic forms and Zoshchenko's short stories is 'Amerikanskaia reklama' (1926) (SS I, pp. 329-30). Here the interrelation is different. This is not a parody of the form, but a satire of the effects of the letter of complaint, as well as of the immense proportions of the housing crisis. In its theme and meta-satirical thrust it has much in common with 'Krizis' and the other meta-satirical stories mentioned in relation to that story.

A specific feature of the feuilleton/letter of complaint satirised in "Amerikanskaia reklama' is its factual basis, in particular the tendency to indicate the precise address of the target of the satire. In Zoshchenko's story the rabkor's letter gives the precise address of the landlord who is charging an exorbitant rent. Rather than working to expose the landlord to shame and ridicule, as good socialist satire should, this works like an advertisement and attracts a huge crowd of people willing to pay three times the original rent and more to secure the flat.

This is not an example of Zoshchenko's use of the stylistic devices of journalistic satirical forms to revivify the short story form. It is, however, a further example of the ambiguous attitude that he adopts to the satirical forms. At times he employs them and on other occasions he satirises them. In 'Amerikanskaia reklama', more than anywhere else, Zoshchenko shows the letter of complaint to have precisely the opposite effect to that intended.

\section{Immediate Topicality}

The journalistic component of Zoshchenko's work in the 1920s is nowhere more evident than in the extreme topicality and often ad hoc nature of his stories. This was 
a feature of the feuilleton, a journalistic form in which immediate topicality was paramount, that he incorporated into the short story.

The most widespread and evident aspect of such immediacy is that of situating the story as occurring recently through the use of temporal deixis: linguistic time markers that assume a shared present. These deictic markers are typical of the spoken language, where speaker and listener are in the same place at the same time, but they are also common in newspapers, which also assume a shared time-frame. Zoshchenko uses temporal deixis in almost every story that he wrote: 'Bania' for example stipulates that the story occurred last Saturday. 'Zakoriuchka', 'Draka', 'Sobytie' and 'Melkoe proisshestvie', for example, all begin with the words: 'Vchera'...' (SS I, p. 410; p. 396; p. 395; p. 382).

With other stories, immediate topicality is not textual but is clear from their publication context. 'Rezhim ekonomii' (1926) (SS I, pp. 342-43) is such a case. It first appeared during the campaign for economy measures. The next issue of Begemot after the publication of Zoshchenko's story was devoted to this campaign and featured a cartoon on the cover with the eponymous hippopotamus saying that the measures have had no effect on him since he never ate caviar or quail anyway and always walks everywhere. ${ }^{81}$ There is also a picture of a three-legged chair as an example of the economy measures. A number of satires in that issue suggest that the measures are likely to lead to more bureaucracy rather than to any genuine savings. In the story, Zoshchenko uses a skaz narrator who claims to have made genuine savings by not heating the toilet, a measure suggested by the woman whose job it was to drag logs to the toilet stove. The stove's chimney-pipe breaks off as a result of it not being used in the cold weather. Though the narrator puts this down to the fact that it was built in Tsarist times, the reader realises that this is in fact the upshot of the economy measures and the measures end up wasting money.

There are many other stories that contain more obscure references to contemporary figures or events related to the context of the publications in which they were first published. One example of this is the ending of 'Kitaiskaia tseremoniia' 
(1924) (SS I, pp. 206-08), which contains a reference to Diadia Iasha, who was a regular contributor to Krasnyi voron. Often the subjects of the stories were determined by a themed issue of the magazine in which they came out. Typical of this phenomenon is 'Zabytyi lozung' (SS I, pp. 226-28), which was written for the International Women's Day edition of Krasnyi voron in 1924 (No. 9, March 1924). The whole issue is devoted to the question of women. 'Tochka zreniia' (SS I, pp. 27576) was written a year later for the same occasion. 'Monter', (SS I, pp. 355-56) under its original title of 'Slozhnyi mekhanizm' appeared in a special issue of Begemot devoted to the theatre (No. 43, 1926). Similarly, 'Pushkin', (SS I, pp. 373-75) which was originally called 'Grob', appeared in an issue of the same magazine devoted solely to the 90th anniversary of Pushkin's death (No.7, 1927).

Other stories refer to the time of year at which they were published. Both 'Ispoved"' (1924) (SS I, pp. 237-39) and 'Paskhal'nyi sluchai' (1925) (SS I, pp. 28183) (under the title 'Pustiakovyi obriad') appear in an Easter issue of Krasnyi voron ${ }^{82}$. 'Zhulik' (1927) (Uvazhaemye grazhdane, pp. 290-91) and 'Poslednee rozhdestvo' (1923) (SS I, pp. 178-80) both appear in Christmas editions and contain references to Christmas. Similarly, the opening of 'Bochka' (SS I, pp. 338) refers to Spring and appeared in the May 1926 issue of Begemot.

The size of the stories was also determined by their place of publication. Stories first published in Ogonek, such as 'Vor' (1923) (SS I, pp. 136-40) and 'Senator' (1923) (SS I, 132-36) and in Leningrad, such as 'Sluchai v provintsii'(1924) (SS I, pp. 248-52) are far longer than those first published in the satirical publications.

Contextual factors such as these are significant in establishing quite how near journalism Zoshchenko's work is. Indeed, we can see from an understanding of the context that he had little control over the length and themes of his stories. In this context narrative technique and the reworking of ready-made material takes on an even greater importance. 


\section{The Writing Out of Topical References}

Zoshchenko considered his works ephemeral: their purpose was to respond to contemporary needs, and he used the language of the everyday in order to have an immediate effect. He did not see his stories as works of great literature capable of standing the test of time ${ }^{83}$ Certainly his language and the forms he chose display a deeper imprint of their time than neutral standard literary language and a more deliberately enduring form like the novel could. This in part explains why Zoshchenko had no compunction in altering the stories for publication in collections.

Though Zoshchenko never imagined that his works would last, they did. Though they are constructed from the ephemeral, they succeeded in making the ephemeral lasting. This forced him into the Russian literary tradition that he had attempted to break from and end.

Zoshchenko's rejoining the literary tradition at the end of the 1920s was not simply part of an internal or textual dialectic. There were also external pressures forcing him to gravitate towards more properly literary forms. In particular, from 1927, the satirical press was subjected to increasingly severe control: in 1928 Begemot and Smekhach were merged and then closed down, and by the end of the decade there were no satirical magazines left in Leningrad. The only satirical magazine still published after 1930 was Krokodil, which was published in Moscow, where the authorities could keep an eye on it. This restriction of the avenues that he had previously exploited for publication forced Zoshchenko to reevaluate his attitude towards literature. As late as 1929 Zoshchenko said in response to an offer to publish a proper literary edition of his works: 'Ia khochu eshche goda dva na vole poguliat'$s$ dikim chitatelem delo imet ${ }^{\prime} .{ }^{84}$ He had greatly overestimated the length of time he would be allowed to enjoy himself, since later the same year the writer began publishing a six-volume collected edition of his works. From this point onwards it became necessary to present himself as a more properly literary writer. The position he had previously occupied, between journalism and literature proper, was no longer 
tenable, especially not for a satirist. As a result it became necessary to present his past in a different light: he had to rewrite his earlier stories. ${ }^{85}$

In the collected works of 1929-32 he enhanced the effect of his compressed syntax by spacing the sentences out and creating more paragraph sentences. This also made it seem more literary, more deliberate, and less like the semi-literate scrawlings of a demented rabkor. Moreover here, and for subsequent editions of his work, he reworked the language and rewrote many of the stories, often filtering out references he may have seen as too specific to the time at which they were written, and therefore too journalistic.

The alterations to 'Bania' discussed above have this effect of filtering out overly journalistic touches. Another example is 'Tiazhelie vremena' (1925) (SS I, pp. 26667). This story first appeared with a newpaper cutting as a subheading:

\section{В магазин Кредитиного тов-ва в Егорьевске зашел один гражданин вместе со своей лошадью и приказал примерить ей хомут. (Раб. Москва, №.295) ${ }^{86}$}

This extract is not attached to the subsequent editions of the story. By removing it from subsequent versions of the work, it is made to look more like a short story than a feuilleton.

'Plokhoi obychai' (1924) (SS I, pp. 232-33) in its first published form is highly topical. In the rewritten form the emphasis of the story changes substantially. The magazine published version refers to a decree of that February that makes tips legally equivalent to bribes. In that version of the story there is a long introduction in which the narrator claims that the decree saved his life. Whereas in the later version, the narrator simply decides not to 'tip' the medical attendant anymore, in the original version it is the decree that brings salvation from his zealous attentions. The essence of the story is the same: what he calls a tip is in fact a bribe anyway. Nevertheless, in the original version the narrator is more cunning in using pious reverence for the decree as a way of stopping the medical assistant and presenting himself as a law- 
abiding citizen. This, like all the changes, is an apparently minor thing. But Zoshchenko's is a literature of minutiae.

'Neizvestnyi drug' ${ }^{87}$ (1923) (SS I, pp. 146-48) was also rewritten to remove references that were too contemporary. Here the story suffers very little, but the filtering out of these details is still relevant. The couple are said not even to have left the house to see the film Dr. Mabuse. This was a film that was very popular at the time in the USSR. Moreover, the amount of money that they lose is calculated according to the sovznak- or denznak of the period up to 1924 , as a trillion rubles in money signs.

These amendments are generally in accordance with the spirit of the original works and make them more accessible to a posterity unaware of the minutiae of 1920s life. However, it seems to me that a significant aspect of Zoshchenko's work is its journalistic topicality. In rewriting and altering his works, Zoshchenko made them more literary. His new work of the 1930s likewise became more literary in form and language. This was a response to the closing down of the publications in which he had published throughout the 1920 s and to a cultural situation that discouraged his marginally literary language. However, by rewriting his earlier work, he was obscuring the quasi-journalistic roots of his art.

\section{Zoshchenko's Skaz and Journalism (Conclusion)}

In this chapter we have attempted to define the journalistic style that Zoshchenko was reproducing in his art, his intention in doing this and to illustrate how his reproduction of that style worked in practice. In particular, we have examined how Zoshchenko reworked letters to the press, how he reproduced the feuilleton and the letter of complaint forms, and how he recreated the language and mentality of the letter writers. Our aim in doing this has been to gain a better understanding of Zoshchenko's relation to the style of his narrator, to understand his skaz better. However, it seems that his intentions are intractably ambivalent. There is also an 
ambivalence as to whether his 1920 s stories are literary or journalistic. Zoshchenko was both attracted and repulsed by documentary journalism, just as he was attracted and repulsed by literature. His works are neither wholly fiction nor wholly journalism. They employ journalistic devices, and a language and narrator figure largely derived from journalistic sources both for their own sake, and to ridicule them.

Yet this ambivalence in itself seems so consistent as to imply some kind of worldview. Zoshchenko appears to have been attracted to ambivalent generic forms, ambivalent stylistic devices and an ambivalent narrator figure precisely because they suited the expression of what he saw as an unresolvable conflict. In the next chapter I propose to examine the technique of the stories as a whole, and attempt to infer the wider implications of this ambivalence. 


\section{Chapter VI}

\section{Zoshchenko's Skaz Narration}

In the previous chapter we analysed the stylistic input of journalism in Zoshchenko's use of skaz. But not every Zoshchenko short story that employs skaz bears traces of the direct influence of journalism. The journalistically influenced stories must be related to the broader context of Zoshchenko's use of skaz as a whole and to his short stories in general. In this chapter, we shall attempt to do so, and in so doing, strive to ascertain or infer Zoshchenko's underlying purpose in employing the skaz narrative technique.

\section{Fallible Narrators and Unstable Statements}

As we saw in Chapters II and III, the skaz narrative form deviates from impersonal authorial narration, in particular by employing a number of dialectal, regional and colloquial usages unacceptable to such norm narration. In so deviating, it sacrifices the authority of impersonal narration and invites challenges to whatever claims it makes. In other words, skaz narration, by its nature, suggests the possibility that the narrator is fallible, and does so far more than standard Ich-Erzählung. Zoshchenko exploits this possibility in a number of different ways.

A reader coming to Zoshchenko's stories for the first time is typically struck by their apparent chaos. The narrator appears to have great difficulty in getting to the point and in successfully distinguishing relevant from irrelevant information. Moreover, the narrators and characters make many linguistic errors and include language of sharply discordant registers. The language of Zoshchenko's stories has been amply described and commented ${ }^{1}$, and, where it is that of the narrator, there can be doubt that it is skaz. However, what interests us about this language is whether it is being employed for the purposes of parody or for stylisation. This is not properly a linguistic question, since, as we saw in Chapter II, it is the nature of both stylised and parodic skaz to employ language that deviates from the norm language of literary 
narration, and parodic skaz cannot be defined according to a linguistic formula. Rather, if we are to describe Zoshchenko's skaz in the light of Bakhtin's definition of it as a bi-polar, double-voiced discourse, we must find the two planes, or the two voices present in a Zoshchenko short story. This is likely to be most clearly illustrated in cases of parodic skaz, since in such examples of the technique, the two perspectives tend in different directions, i.e. they are in contradiction with each other.

'Sila krasnorechiia' (1927) (SS I, pp. 375-77) is a Zoshchenko story that contains such a contradiction between two points of view, and seems suited to our discussion, because it explicitly explores the question of language. In particular it comments upon the language of rhetoric and its power to persuade people and influence events. In this story the narrator watches the trial of a burglar. Having been prevented from leaving by the old man next to him, the narrator tries to amuse himself by speculating as to the outcome of the trial. However, the old man tells him that there is nothing to speculate about, since the penal code stipulates a punishment of four years' imprisonment, and that is what the defendant will get. Nevertheless, the narrator is swayed by the prosecuting counsel's speech. Under its influence the narrator describes the defendant as a terrifying subhuman with a low forehead and a protruding jaw. He even wonders whether the death sentence will be passed. The old man dismisses such notions and again points out that the crime is punishable by four years' imprisonment. When the defence team make their case, the narrator changes his opinion entirely, and praises not only the defence counsel, but the power of eloquent language as such:

\section{Какая сила красноречия! Какой неподельной простотой и искренностью звучала вся его речь! \\ Красноречие - это большой дар. Это большое счастье - обладать такой способностью похорять людей своими словами. И диктовать свои желания.} (SS I, p. 376)

Touched by the power of this language, the narrator now sees the defendant as a simple person with not such a low forehead, and with a quite normal jaw. Like the 
narrator, the public is moved, and no one thinks he will get more than a year in gaol, apart from the old man, who repeats the opinion he expressed at the start. The sentence passed bears out what he has been saying all along: the defendant is given four years in gaol. Despite this experience, the narrator ends the story by saying that he likes eloquent speeches because they lead to fewer mistakes.

This praise of the power of language is deeply ironic, since the defendant was sentenced to the prescribed term of imprisonment, regardless of the verbal powers of either barrister. Moreover, while the narrator celebrates the power of language to persuade, language in this story is at best an entertaining but meaningless game. At worst it is a dangerously misleading medium capable of whipping up hysteria. Under the influence of the barristers, the narrator and, it seems, the rest of the audience, change their opinion several times. In this respect the capacity of language to convince and compel others is illustrated in this story. However, this has no influence upon the course of the trial. The narrator's celebration of eloquence and claim that it obviates error is itself an error. Language is the unstable province of confusion and misinterpretation. In this story, language is a sphere of illusion that exerts influence over gullible people, but is powerless to alter the deeper processes that govern human destiny.

However, whatever this story tells us about language, it is itself composed entirely of language. Whatever we decide about the narrator is based on what he has himself told us. It would seem then that there are two separate tendencies of the narrator's language in this story: on the one hand language that faithfully reflects life, that slavishly follows the narrator's experiences of an event, and on the other hand, language that interprets that experience, that draws lessons from it, and relates it to broader concerns. These are the two levels of the story and they contradict each other for an effect of irony. However, this irony is made possible by keeping the description of an experience and the interpretation of it separate. This distinction underpins the Zoshchenko skaz narrative, but it is a tenuous one. For all the incompetence of Zoshchenko's skaz narrators, they describe the world well enough for the reader to see, for example, a contradiction between what the narrators experience and how they 
interpret that experience. In 'Sila krasnorechiia' itself, we see that the narrator's description of the defendant changes in response to the various arguments of the prosecution and the defence: making the accused man look at first a brute and then an innocent. Even the narrator's description of the shape of the defendant's skull changes. Description is informed by interpretation. Nevertheless, in the structure of this and a great number of Zoshchenko's skaz stories, this distinction is maintained through the contrast between the narrator's description of an experience or an incident and his interpretation of it. This is made possible because the narrator is not rigorous enough to realise that there is a discrepancy between the two, and not cunning enough to doctor his description in such a way as to force it to corroborate his interpetation. In some cases, as we shall see, he perceives the discrepancy at the end of the story and renounces his initial assertion or interpretation.

In 'Sila krasnorechiia', the narrator sees his experience at the trial as a general illustration of the power of oratory and the power of language over people and events, and encourages us to agree with him. We have already been attempting to respond to this challenge in the preceding paragraphs, but a few more comments are in order.

In the mouths of Zoshchenko's narrators and characters, language is feeble and untrustworthy. Though it can be used to fool those naïve enough to be taken in by it, it is itself at the whim of obscure forces. Characters and narrators repeatedly attempt to explain, interpret, make sense of, draw lessons from and make assertions about their experience of an event, but like the narrator in 'Sila krasnorechiia', they fail to do so satisfactorily. Their interpretations are often wrong and constitute an apparent level of the story that we must see beyond in order to appreciate what really occurred, and its true significance. It is opinions about something seen or heard and attempts to suggest the broader societal or universal significance of an event, that are the most hazardous and unstable linguistic operations in Zoshchenko's stories. Time and again the narrators' and the characters' capacity to make sense of their experience of an event, to make claims about life in general on the basis of a particular incident and to fit an experience in to a more ambitious framework informed by ideology or values, is shown to be untrustworthy and highly unstable. Experience and the evaluation of it 
repeatedly come into conflict, and appear to be divorced. Repeatedly, the interpretation turns out to be an apparent level of reality. Reality refutes interpretations. There is a tension or a discrepancy between them.

This discrepancy is not celebrated, indeed it is often a miserable situation for Zoshchenko's characters and narrators. However, it is often comic too. In 'Sila krasnorechiia', the gap between the narrator's celebration of the power of oratory and its actual influence on the course of events constitute two levels of the story. The event of the story and the narrator's or character's statement about that event are the two levels of $s k a z$, the two opposing points of view, the two voices incarnating conflicting intentions that Bakhtin first described (see Chapter II). He described them as parodic $s k a z$, but they are also an example of what we might call comic incongruity. ${ }^{2}$ Zoshchenko's stories repeat this predicament many times over, with numerous subtle variations.

\section{The Discrepancy between Experience and Interpretation}

One of Zoshchenko's most famous short stories, 'Aristokratka' (1923) (SS I, pp. 170-73) is a narrator-participant skaz story in which the narrator's interpretation of his own narrative is undermined by what we learn of it. In this story, Grigorii Ivanovich, for whom the mysteries of plumbing represent his sole conversational gambit, starts by saying that he dislikes aristocratic women. He then briefly defines an aristocratic woman as one with fancy stockings, a pug-dog and a gold tooth, and tells us that he once dated such an aristocratic lady. His strange definition of aristocrats already leads us to question his claim: a gold tooth is hardly incontrovertible evidence of blue blood. Furthermore, in the course of the story, what we learn about her suggests that the woman was not an aristocrat at all. After all, it is for the measly reward of a theatre ticket and three pastries that this woman endures the advances of the irredeemably tedious Grigorii Ivanovich.

On closer examination of Grigorii Ivanovich's definition and stated dislike of aristocratic women, the reader is able to see that what he claims to dislike about this woman from Flat Seven, is in fact what first attracts him to her. He was attracted to the 
same 'classiness', that he cites as repellent to him at the beginning of the story. Her gold tooth is what he initially likes about her: he mentions it three times in the story. Nevertheless, when she ends up costing him too much money, he cites the same gold tooth as proof that she is an aristocrat. This is an attempt to condemn her opportunistically as a class enemy according to the prevailing ideology, and thereby to imply that they fell out for ideological or political reasons. The story shows how the meaning of the word 'aristokratka' changes for Grigorii Ivanovich during the course of the story.

'Aristokratka' is an excellent example of the instability of the skaz narrator's opinions. The cause of this about-turn is that she ends up costing him too much money, by eating too many pastries. This is another pattern that Zoshchenko uses a number of times: a potentially romantic plot is disrupted by considerations of money, of personal possessions. Love and romance are repeatedly shown to be unstable and insubstantial. They occupy an analogous position to interpretation and opinions, since like them, love and romance in these stories exist on an apparent level of reality, and are liable to be exposed as such by the more basic need for money and the drive to acquire or retain possessions. This undermining of love is often brought about by a theft. In, for example, 'Neizvestnyi drug' (1923) (SS I, pp. 146-48), a couple that never go out receive anonymous letters: the wife's appeals to her sense of melodrama, the husband's to jealousy. They go to the place indicated by the letters at the correct time, find nothing and return home to find that they have been burgled. The apparently romantic plots of melodrama and jealousy boil down to theft. Theft is also used in 'Chasy' (1926) (SS I, pp. 332-33), to show how a man's gallant manners are very flimsy: when Vasilii Mitofanovich realises his watch has been stolen, he immediately blames his girlfriend. This theme is also explored in non-skaz stories, such as 'Liubov"' (1923) (SS I, pp.193-95), where Vasia Chesnokov one moment declares his undying love and claims to be willing to sacrifice himself for Mashen 'ka, and the next minute the couple are mugged, and he complains to the thief that he is the only one whose coat and boots are being stolen and suggests that the thief take Mashen 'ka's fur coat rather than his own. 
Professions of love and attempts to be charming or polite are shown to be only superficial and misleading. In stories with such plots, the implication seems to be that people have a deeper bond with objects than with one another. The interpersonal sphere of opinions, conventions and manners is typically unstable. When brought up against objects, and the striving to acquire them, all such refinements buckle and surrender.

In a number of Zoshchenko's stories, the world of objects is shown to govern interpretations in a very direct way. 'Tsarskie sapogi' (1927) (SS I, pp. 377-79) is a clear example, in that the narrator's evaluation of tsarism changes according to the state of his boots. When he first buys them, he considers 18 rubles a very reasonable price for the Tsar's or 'tsarist' boots. But when they fall apart after four days, he grumbles that if they had been Soviet-made, he could have made a complaint, and maybe even got someone sacked, but since they are 'tsarist' there is nothing he can do about it. Similarly, his friend Katerina Fedorovna Kolenkorova initially calms the narrator down, arguing that in the ten years since the Revolution, any royal boots were bound to suffer the ravages of time. However, when the blouses she bought at the same sale come apart after the first wash, she too curses the tsarist regime.

In other stories it is not characters' opinions as such that change to suit objects, but their relations to each other. In 'Stakan' (1925) (SS I, pp. 305-06), a cracked glass, and an apparently stolen light bulb in 'Gosti' (1927) (SS I, pp. 363-65), cause complete reversals in relations between the characters of the story and their evaluations of each other. Friendship and hospitality turn to enmity and hostility. Both are shown to be as fragile as love and romance, or opinions and interpretations, and like them, pale before the importance of objects. In 'Passazhir' (1925) (SS I, pp. 299-301) the narrator asserts that: 'Chelovek... vse-taki vazhnei, chem veshchi...' (p. 300). This claim is itself not borne out either by that story, or by a large number of Zoshchenko's stories. People consider their relations with other people less important than their relations with things. On the evidence of a great number of the stories, they are right to do so, since objects have far more power than people. 
In each of these cases human opinions, evaluations and assertions, especially declarations of love or friendship, are forced to change by objects. Objects and the characters' relations to them form a second perspective in the stories which undermines that of the narrator's evaluations, assertions and opinions. Just as in 'Sila krasnorechiia', the narrator's claims are in conflict with and powerless over the world.

Zoshchenko also explores the instability of interpretations and opinions through the theme of self-interest. This is linked to the notion that material objects have more power over people than people do over each other. Consequently, self-interest is often explored through the familiar theme of theft. In 'Vory' (1925) (Uvazhaemye grazhdane, pp. 259-60), for example, the skaz narrator-participant begins the story complaining about the prevalence of theft, and mentions that he himself has been a recent victim of crime. As a victim he is in favour of draconian penalties for theft and enthusiastically relates something he has heard about how thieves used to have their hands cut off in Finland and how this had a beneficial effect on morals. When the narrator's suitcase is stolen, he reports the theft and tells the militia to tear the thief's hands off when they catch him. The officers laugh and ask the narrator to return the pencil he has just stolen from them. Having returned it, the narrator rethinks and revises his opinions on the punishment of thieves. The narrator changes his opinion and evaluation in accordance with his own position as victim of theft or thief. Selfinterest too is universal, and no opinion or view can withstand its influence.

The theme of self-interest underpinning opinions and interpretations is also explored through stories in which men advocate the liberation of women. In 'Zabytyi lozung' (1924) (SS I, pp. 226-28), a journalistically influenced letter to the editor, a man advocates the equality of the sexes. We later realise that this is because he does not want to have to pay for women when he takes them out for dinner. Similarly, in 'Semeinoe schast'e' (1924) (SS I, pp. 262-64), the narrator visits Egorov, an acquaintance who proudly boasts that he has 'liberated' his wife, Motia: they now eat in the canteen so that she need no longer do the cooking and now, he says, has so much free time that she can sew all day if she wants. The narrator asks whether Motia 
would not rather sit and read the paper like Egorov himself rather than constantly sewing. Egorov is completely astounded and takes offence: 'Kak zhe ei ne shit', kogda ona baba', he exclaims. When the narrator leaves, soon afterwards, he overhears Egorov claiming that the real reason for the narrator's criticism was because he was unhappy at not being fed. Altruism, these stories suggest, is an illusion. Those who claim that their opinions are based on it are invariably using it to cover base motives.

Self-interest is the most substantial motive in the characters' and the narrators' conduct. If they attempt to advance opinions based on anything but such considerations, self-interest will reveal itself as the genuine and the fundamental concern. Once again this results in the displaying of a discrepancy, the laying bare of the two perspectives present in the Zoshchenko skaz short story. As with the previous stories, the characters' opinions are shown to be flimsy, and subject to the dictates of deeper, more powerful forces.

However, self-interest and the lure of objects are not the only forces that serve to undermine opinions, interpretations, and explanations. The narrators and other characters come to erroneous conclusions about something they see or experience for a myriad of reasons. In 'Beshenstvo' (1926) (SS I, pp. 346-47), for example, the narrator is one of a group of men who kill a completely normal dog because they are scared of rabies and think that it might be rabid. In 'Ulichnoe proisshestvie' (1925) (SS I, pp. 303-04), the narrator is part of a crowd of people who see a militiaman with a woman and start to hurl abuse at the woman whom they decide is a criminal. To the crowd, her crime escalates from illicitly distilling vodka to murdering her husband. The lynchmob atmosphere is only dispelled when it transpires that the militiaman is taking his girlfriend for a stroll.

For the characters in Zoshchenko's stories, and in particular for the narrators, there is a gulf between what they see and experience, and the evaluation or interpretation of that experience. They tend to conclude that two and two are five. There are similar discrepancies in the stories in which a relation of love or friendship is affirmed at the beginning only to be undermined by an event in the story. In such stories, love or 
friendship may be said to be an interpretation of the relation between the characters, but neither can stand up to the actual nature of life, to the power of objects and to the course of events. The contrast between the two levels of the story, these erroneous interpretations and the exposing of them as such in the course of events produce some of Zoshchenko's greatest comic moments.

Yet this gulf between a character's experience and his interpretation of that experience is not only a comic one. Even in 'Beshenstvo' and 'Ulichnoe proisshestvie' there are unfortunate consequences, or potentially unfortunate consequences, of the narrator's and the crowd's misinterpretation of the situation. These stories seem to link the malleable and unstable nature of human opinion to violent acts and mob rule. Many of the other stories too derive humour from unpleasant aspects of human conduct, such as selfishness, acquisitiveness, and dishonesty. Moreover, the general predicament of the characters in Zoshchenko's short stories is one in which not only opinions and interpretations, but even attempts to make sense of existence by trusting one another, through friendship or love, are repeatedly shown to be misleading ways of thinking or acting. However, if Zoshchenko's skaz stories are balanced between comedy and tragedy, between parody and stylisation of the narrator, then it is because a number of stories encourage the reader to disregard the discrepancy between the narrator's initial account of events, and what we subsequently glean about them.

\section{Accepting or Overcoming the Discrepancy}

In Zoshchenko's stories, as we have seen, there often appears to be a discrepancy between, on the one hand, the narrator's assertions, interpretations or opinions, and on the other hand, the incident or experience which comprises the main event of the story. Ershov argues that in the typical Zoshchenko short story the title and the narrator's evaluation or assertion are directly contradicted by the event narrated. He uses 'Schast'e' (1924) (SS I, pp. 211-14) to illustrate his point: 
изображаемое, а читатель либо догадывается, либо точно знает, что подобные оценки-харахтеристики неверны. Это вечное борение между утверждением сказчика и читательским негативным восприятием описьваемых событий сообщает особый динамизм зощенковскому рассказу, наполняет его тонкой и грустной иронией. ${ }^{3}$

Effectively Ershov sees Zoshchenko's irony as antiphrasis. Broadly, this is the spirit in which we have been reading Zoshchenko's use of skaz narration in this chapter so far. However, it is possible to read the lack of correspondence between the narrator's assertions or interpretation and the experience narrated in a different way. The reader may decide that the discrepancy is not important, and disregard it. This way of viewing the relation between the narrator's interpretation and his experience permits the reader to see 'Schast'e' as sincere. We can admire Ivan Fomich because he has managed to find happiness in a world, which, as the narrator and Ivan Fomich both suggest, gives little scope for it. He has managed to transform a trivial incident such as the chance smashing of a window into happiness. ${ }^{4}$ To be happy with so little is something to be applauded, and not seen as a satirical comment on the fact that there is so little to be happy about.

The sort of perspective that would permit us to admire Ivan Fomich in 'Schast'e' would presumably stress humanity's capacity to change. It would see in this infinite adaptability an ability to get used to the worst possible situation, such as to the presence of carbon-monoxide fumes. This, it would argue, is the highest expression of the human. This talent for enduring adversity grants us our few glimpses of happiness. This is the view of humanity expressed in the last sentence of 'Koshka i liudi' (SS I, pp. 406-08 (p. 408): 'Chelovek ne blokha - ko vsemu mozhet privyknut'.' In this story the narrator fails to persuade the housing office to change his leaky stove. An ironic reading prompts us to ask whether human beings cannot change a political and economic situation where they are being asked to endure the fumes from leaky stoves. But if change does not come, if the leak remains, then the capacity to adapt to the worst is praiseworthy. To aspire towards contentment not just with the everyday, but 
with an impoverished world, is the sole path to happiness. This is a way of thinking diametrically opposed to the idea of revolution or revolt. Ivan Fomich willingly submits to the domination of objects and chance. He is happy being ruled by windows and the chance breaking thereof.

There is another way in which Zoshchenko's stories treat the discrepancy between evaluation and experience. In a number of Zoshchenko's stories, though the narrator's interpretation appears not to fit, it is possible to make it fit if we disregard the particular experience of the narrator. As we have seen, man is endlessly defeated by objects throughout Zoshchenko's work. However, in these cases he continues to struggle against them, and their reifying influence upon him. He fights using his wits and his imagination. Here interpretation is all that he has left, and unlike in 'Tsarskie sapogi', he stands by his initial opinion, despite being betrayed by the object. A good example of this is the aptly named 'Rubashka fantazi' (1927) (SS I, pp. 386-87). Here the narrator buys a new shirt to go to a party and gets it laundered only to find that it has shrunk. He has to put his old one on top of it to distract attention from it. The story ends with him saying that the party went well and no one noticed the shirt. Yet he presumably bought the shirt so that people would notice it. This resolute ability to derive comfort from the worst setback is, in its own way, heroic. It is dependent on the narrator's powers of imaginative transformation, on his ability to remain true to his interpretation, even though the object fails to justify his faith in it. This narrator refuses to succumb to the treachery of things and the perfidious indications of experience. This way of thinking is exemplified in 'Zelenaia produktsiia' (1927) (SS I, pp. 394-95): 'No nado byt' optimistom i nado v kazhdom pechal'nom iavlenii nakhodit' khoroshie storony.' (p. 395).

'Zakoriuchka' (1927) (SS I, pp. 410-12), is a further example of the struggle between experience and the interpretation of it. Here the narrator praises the efficiency and lack of bureaucracy of a government institution. The story itself is a catalogue of an exhausting experience of bureaucracy and the narrator leaves in a terrible state of nervous exhaustion. Here we are faced with a straight choice between deciding whether there is a lot of bureaucracy in the USSR or whether there is very little. The 
narrator-participant's experiences are of bureaucracy, but he does not see this as at all bureaucratic. We have to decide whether to believe the narrator's experiences or his opinions. We might think we are being encouraged to choose experience, but that would be a simplistic reduction of the competing forces of the story. Indeed, the very title of the story, 'Zakoriuchka' refers to the little mark that the staff put on the narrator's papers, permitting him to pass straight through when he returns to the office. At the same time it means a hitch, or drawback. The word symbolises the choice readers are confronted with: is it a sign of progress, or a failure to progress?

'Galosha', (1926) ${ }^{5}$ also presents us with such a choice. In this story, the narrator's search for a lost galosh means him having to describe it in immense detail to the lost property bureau, and when they identify it from his accurate descriptions, they still will not give it back because he has not got the requisite chit proving that it his. After even more bureaucratic to-ing and fro-ing, the narrator gets the chit, his efforts are rewarded, and he gets back his lost galosh. The only problem is that in all the fuss he has lost the other galosh in one of the offices he had to go to. Yet the narrator barely mentions the fact that he lost the other galosh, he concentrates instead on the galosh that he has found, seeing it as a proof of the perfect functioning of Soviet institutions. Indeed, the found galosh becomes an inspirational object that he looks at whenever he feels low. Here it is not a question of totally ignoring experience: the narrator's joy and optimism are based on one aspect of his experience, the fact that he found his lost galosh. They just blot out the more significant context, that he lost his remaining galosh, and a single galosh is no use to anybody. This selective blindness on the part of the narrator is extremely significant.

The blithely optimistic rejection of the evidence of experience is a powerful strand running through Zoshchenko's work. We have already seen it in the journalistic works such as 'Bania', where the narrator claimed that you could get washed in Soviet bathhouses, even if in actual fact he was unable to do so. Similarly in 'Rostov' (1927) (SS I, pp. 412-13), the narrator is sitting on a bench reading when he is frightened out of his wits by a stranger wearing only a pair underpants leaping over him. When he realises that this is athletics and not hooliganism, he immediately discounts his 
experience of fear and praises the beneficial effects of sport. Faced with a choice between trusting his own experience and discounting it as irrelevant by interpreting reality through a comforting slogan, as a rule he chooses the latter.

Either the narrator discounts his experience and disregards the perfidy of objects, choosing instead to trust his uncorroborated interpretation, or he submits to the rule of things with good cheer. Whether he accepts or ignores the discrepancy between experience and interpretation, the narrator puts a benign construction on a disturbing reality.

The personalised narrator is an individual, and the interpretation is sometimes a more flattering account of Soviet society than that suggested by the narrator's experience. In other words the narrator's experience tends to confront received wisdom. But Zoshchenko's narrator is not a rebel or a strong individual, and is simply not made to struggle against the existing order or its flattering account of itself. $\mathrm{He}$ is more of a herd animal who would prefer to be wrong with the majority than right alone, a meshchanin. In the context of the Soviet Union even of the 1920 s not only the meshchanin, but also most people could justifiably be scared of being isolated in opposition to society and the government. However, to take this view is to assume that these opinions and interpretations function as parodic skaz, i.e. as irony, and that we should trust the narrator's personal experience instead. It is to conclude that Zoshchenko was primarily satirising the shortcomings in Soviet society in his narrator and inviting the reader to disregard the original interpretation and insert one more in keeping with the narrator's experiences, in the manner of irony as antiphrasis.

However, we must hesitate before doing so. To do so is to read into this writer a prophetic insight as to the weakness of Soviet Communism. This interpretation smacks too much of hindsight. Instead, I propose that we see the narrator's interpretations as a form of daring optimism in the face of the evidence of experience. These stories are about making sense of one's experience in general, and not just about the discrepancy between official accounts of Soviet life and the narrators' experiences of that life. The optimism of the stories involves discounting the fragmentary nature of individual 
experience for the sake of a coherence that ultimately finds no corroboration in the empirical world. It functions in a similar way to an irrational act of faith: the credo quia absurdum of a Soviet Abraham. Biographical evidence shows us that Zoshchenko persistently saw health and optimism as linked: he seems to have believed that if he was optimistic then he would be healthy. ${ }^{6}$ In this light it would seem that the narrator, like Zoshchenko himself, was striving despite evidence to the contrary, to interpret experience optimistically. The scepticism fostered on one level of his narrative, the relentless doubt engendered by the use of a skaz narrator and that narrator's experiences, are counter-balanced by his implacable optimism and indefatigable cheerfulness. This tension can be illustrated by reference to one of Zoshchenko's most typical devices.

\section{Discrepancy as Euphemism or as Optimism?}

The tension between interpretation and experience expresses itself even on the level of one of Zoshchenko's smallest stylistic devices. There is a repeated pattern in Zoshchenko's short stories where the narrator makes an assertion and then attempts to qualify it. The qualification undermines and sometimes even serves to invalidate the original assertion and we are left trying to decide whether we want to believe the original assertion or the qualifications of it. Was the original statement an optimistic assessment or a euphemistic attempt to hide the facts?

An excellent example of this comes in 'Kachestvo produktsii' (1927) (SS I, pp. 36567), where the narrator describes some of the items left behind by the German as 'pochti dve pary kal'son. I sviter pochti ne rvanyi.' To picture something which is not quite one pair of long johns, let alone not quite two, demands some considerable imaginative effort. Ultimately it would seem that we are dealing with some rags that though once long johns, cannot quite be called that anymore, so advanced is their state of disintegration. Only an act of fervent optimism, infinitely greater than that needed to turn a half-empty glass into a half-full one, only a supernaturally cheerful Panglossian capacity could transform these rags into 'nearly two pairs of long johns'. The story as a whole shows how foreign goods are transformed into a magic class of 
especially powerful objects when placed in the context of the squalor and optimism of Zoshchenko's world. This optimism itself, of course, is that we saw summarised in 'Zelenaia produktsiia', a tenacious capacity to look on the bright side spawned by the squalor of the time, and an inability to conceive of a transformation that would make such optimism and such underwear unnecessary.

Such stylistic devices often resume the plot of the story in a kind of mise-en-abîme. An example of that comes in 'Rostov', (1927) (SS I, pp. 412-13) where the narrator states that it is a quiet town. One of the things that he likes about it is that there is no hooliganism there whatsoever. He then goes further still and claims that a young woman can happily walk around the town at night alone. This claim is immediately qualified, and the narrator concedes that a woman might not be able to walk around alone. Ultimately the only fact the narrator can adduce in support of the notion that Rostov is a quiet town is that the inhabitants do not swear excessively at passers-by and they allow you to pass without jostling you unduly. This opening is a miniature version of the plot as a whole, where the narrator at first confuses athletics for hooliganism. In this passage, as in the story as a whole, we understand that the narrator is willing to disregard his own personal experience in order to interpret Rostov as a peaceful town, and the Soviet Union as a place in which everything is constantly improving.

Another example of a story constructed in a similar way is 'Mnogo li cheloveku nuzhno' (1927) (SS I, pp. 381-82). It has a similar opening in which assertion is largely undermined by qualification:

\footnotetext{
И жилищньй кризис (...) начал ках будто бы слегка ослабевать. Более ках семнадцать человек в одной комнате нам не приходилось видеть.

И только в одном городе комнату занимало двадцать три персоны
}

The same facts could easily have been used to argue that the housing crisis was as bad as ever, yet the narrator's capacity for interpreting in the light of his optimism transfigures such facts. 
These optimistic transformations may be contrasted with stories where the initial statement is simply euphemism. With euphemism the underlying reality shines through the narrator's attempt to conceal it and unlike in the above examples there is no balance between the two possible interpretations. Instead, the interpretation is shown to be utterly wrong. This usually works in the binary manner of irony as antiphrasis, where we come to understand the opposite of what was originally stated. A good example of this is 'Limonad' (1926) (SS I, pp. 362-63). This story starts with the sentence 'Ia, konechno, chelovek nep'iushchii' (p. 362). The narrator immediately qualifies this by admitting that there are certain social circumstances where drinking is unavoidable. He then tries to limit this undermining of the first assertion by claiming that he never drinks more than two bottles (of vodka) at a time, (i.e. a litre). However, he has to qualify this by the admission that he once drank a 'quarter' (approximately three litres)! By this point we realise that, despite the opening sentence, this man consumes an astounding quantity of alcohol and is effectively an alcoholic.

Another example of such euphemism can be found in 'Gosti' (1927) (SS I, pp. 363$65):$

Но ничего такого предосудительного, хроме нескольких бутербродов, и полбутылки мадеры, двух небольших рюмох и одного графина, обнаружено не было. (pp. 364-65)

Here, as in euphemism in general, the motive for concealment is more one of reticence or duplicity, often from reasons of self-interest or from an implicit fear of upsetting someone, than from optimism.

With these figures of Znshchenko's style we are faced with discerning the euphemism from the act of optimism. In other words we must distinguish irony from the attempt to disregard or overcome it. This tension between comic discrepancy and the attempt to overcome it through resignation or optimism is extremely important in Zoshchenko's work. In the journalistic work, Zoshchenko develops the inherent components of the feuilleton, the fact and the generalisation, and explores the 
possibility that they might contradict each other. Faced with a fact that contradicts the generalisation made on the basis of it, we must decide whether to trust the fact or the generalisation. To believe the generalisation, one must have an optimism that disregards experience, such as that of the narrator of 'Bania'. If we do so, then the story is stylised skaz, in which there is no second, ironic level. If we disregard the generalisation on the basis of what we learn of the incident in the course of the narrative, then the story is parodic skaz. In his skaz stories as a whole, including his journalistic work, Zoshchenko presents us with many examples of such discrepancies. In doing so he presents us with a choice: that between the inherent possibilities of skaz: parody and stylisation. The presence of both parody and stylisation is a consistent feature of Zoshchenko's use of skaz, and is intimately bound up with the writer's attitude to his narrator, to the language that he uses but also to the opinions he expresses. As we saw in Chapter I, critical opinion is deeply divided on the question of this relation between the author and his narrator. ${ }^{7}$ The roots of this controversy lie in a deeply ambivalent attitude on the part of Zoshchenko himself to his narrator.

\section{Zoshchenko's Attitude to his Narrator: Articles and Statements}

As we have seen, skaz is a form that can be used either in order to stylise sympathetically or parody unsympathetically a given language, form or mentality. In the previous chapter we saw how Zoshchenko was attracted towards accessible journalistic forms for the purposes of revivifying the literary idiom. On the other hand, he is also quite clearly parodying the very journalism he claims to be employing. His work as a whole combines these two possibilities. The contradiction that lies at the heart of Zoshchenko's intentions in his stories as a whole can be seen clearly if we look at what he thought he was doing by adopting the mask of a skaz narrator. Zoshchenko's articles consistently link the question of his language with that of the character who uses it. These considerations are almost inextricable from the question of Zoshchenko's language, since the language characterises the narrator who uses it. Here, as we did in the previous chapter with regard to Zoshchenko's attitude to journalism, we shall take the various statements from 1927 onwards as a body of work 
offering a coherent if contradictory point of view. By doing so we can analyse Zoshchenko's statements about and commentaries on his own work, along with the evidence of those who knew him, as a way of defining his attitude to his own narrator and to that narrator's use of language.

One of Zoshchenko's best known statements about his art, 'O sebe, o kritikakh i o svoei rabote', (1927), typifies the writer's deep contradictions. In this article Zoshchenko claims to be a proletarian writer and then alters this to say that he is parodying the sort of proletarian writer who would exist in present conditions:

Дело в том, что я - пролетарский писатель. Вернее, я пародирую своими вещами того воображаемого, но подлинного пролетарского писателя, который существовал бы в теперешней среде. Конечно, тахого писателя не может существовать, по крайней мере сейчас. А хогда будет существовать, то его общественность, его среда значительно повысятся во всех отношениях.

Я только пародирую. Я временно замещаю пролетарского писателя. Оттого темы моиу рассказов проникнуты наивной философией, хоторая как раз по плечу моим читателям. ('O sebe, o kritikakh i o svoei rabote', (1927) Uvazhaemye grazhdane, p. 586)

Zoshchenko seems to suggest that he is attempting to create a new, proletarian literature, part of a positive project for which he seems to have been genuinely enthusiastic. But since that literature and the proletarian writer cannot yet exist he is parodying them. Yet the object of what is here termed parody clearly is not just a language or a form. It is also the mentality of the proletarian writer, and his 'naïve philosophy'. Thus Zoshchenko uses parody here to refer to the reproduction of someone's attitudes for the purposes of ridicule. This is what I argue is more properly the province of irony (see Chapter II). Consequently, Zoshchenko's narrator is a coherent figure, a type given unity not only by his consistent use of language but also by his consistent way of thinking. 
Zoshchenko's use of the concept of parody has a further peculiarity: he associates it with the temporary. Moreover, this is not an isolated instance: he employs it again in Pis'ma k pisateliu (1929) (Uvazhaemye grazhdane, p. 371). This usage implies that 'parody' or irony is temporary and ephemeral and can at best prepare the way for a genuine way of writing and a genuine writer. This passage seems to suggest that all meaningful existence lies in the future, and that the present is a degrading sphere. Thus Zoshchenko explores and ridicules the mentality of a proletarian writer, a creature more properly belonging to a perfect future society who is in fact mired in present-day byt, and, we might add, ruled by narrow concerns. He is 'parodied' and treated with irony, since he will be replaced by the real proletarian writer. Irony has its eyes on possibility, on the future, on bytie, and looks down on the compromises with the everyday that are forced upon the likes of Zoshchenko's proletarian writer. In Zoshchenko's narrator, the proletarian writer is presented as a meshchanin.

However, this petty mentality is at the same time the very one that Zoshchenko claims he gives his writer in order to make him accessible to the present day reader. One part of the attempt to reach an untapped, newly literate audience consisted in the use, as we have seen, of journalistic forms. Another aspect of it was through the 'philosophy' of the stories, the 'naïve' mentality of the narrator: his pettiness, his concern with and susceptibility to apparently minor things is what many hundreds of thousands of readers recognised and responded to. Such concerns are not simply ridiculed. This other dimension of Zoshchenko's stories ensured that parody of the narrator was not permitted to prevail unchallenged.

By unpicking the above passage we find that the aims of sincere democratisation and an attitude of ironic distance are inseparably intertwined in Zoshchenko's attitude to his narrator figure. The coexistence of these contradictory attitudes is the wellspring of Zoshchenko's ambivalence, and makes him such a difficult writer to understand: his attitude is both sympathetic and at the same time one of ridicule; one of both sympathy and irony. His use of skaz is a refusal, or possibly an inability, to resolve this indecision. 
Similar contradictions can be found throughout Zoshchenko's statements about his character-narrator and his language. In the same 1927 article, 'O sebe, o kritikakh i o svoei rabote', Zoshchenko answers the charge that he is willing to do anything to the Russian language just to get a laugh, by arguing that he needs this language to create a new 'type', previously unknown to Russian literature:

Если я искажаю иногда язьк, то условно, поскольку мне хочется передать нужньй мне тип - тип, который почти что не фитурировал раныше в русской литературе. (Uvazhaemye grazhdane, p. 585)

Who is this new character? He has been the subject of much discussion, particularly in Soviet literary criticism, in which most critics, as we saw in Chapter I, consider Zoshchenko's character-narrator to be a meshchanin whom he despises and satirises. ${ }^{8}$ Though, as we have seen, this is part of the picture, it is not the whole picture: few critics have developed Zoshchenko's statement that his new character is a proletarian writer, albeit a temporary one. ${ }^{9}$ There is however a great deal of support for this point of view in Zoshchenko's statements on literature. In Pis'ma k pisateliu Zoshchenko describes some of those who write to him:

Пролетарская революция подняла целый и громадный пласт новых, «неописуемых» людей. Эти люди до революции жили, ках ходячие растения. А сейчас они, худо ли, хорошо, - умеют писать и даже сочиняют стихи. И в этом самая большая и торжественная заслуга нашей эпохи.

Вот в чем у меня нихогда не было сомнения. (Uvazhaemye grazhdane, p. 357)

These 'indescribable' pecple resemble the type from the previous quotation who had never appeared in pre-revolutionary literature. They now write and their ways of writing and thinking serve as prototypes for Zoshchenko's narrators. As such, Zoshchenko feels the same contradictory way towards them: he expresses immense 
sympathy for these newly literate people and at the same time casts doubt as to the quality of what they write. This mirrors the divided sympathies that we saw above in his attitude to the figure of the proletarian writer.

This attitude is repeated in his relation to his readers. In Pis'ma k pisateliu, Zoshchenko notes that the kind of readers who write to him are not typical since they have literary pretensions; he also writes that they are the sort of people that 'my, pisateli, staraemsia izobrazit" v tak nazyvaemykh "khudozhestvennykh" proizvedeniiakh' (Uvazhaemye grazhdane, p. 345). In other words they serve Zoshchenko as examples of the sort of proletarian writer that exists in present circumstances. In the same passage he claims that it is not his intention to make fun of the illiteracy of his readers. Yet later he considered that this is exactly what he had done in Pis'ma $k$ pisateliu, albeit inadvertently. ${ }^{10}$ Zoshchenko has mixed emotions about the readers' letters assembled here. They are semi-literate and worse, but they are also in part sympathetic:

Здесь в этой книге, можно видеть настоящую трагедию, незаурядньй ум, наивное добродушие, жалкий лепет, глупость, энтузиазм, мещанство, жульничество и ужасающую неграмотность. (Uvazhaemye grazhdane, p. 345)

The letters create an ambivalent effect because the worthy and sympathetic coexists with the unworthy and unsympathetic aspects of these people. The same is true of many of Zoshchenko's own narrator-protagonists.

The ambivalence of Zoshchenko's stories can be traced back to the writer's own complex and contradictory feelings about his characters and their language. This is the prime source of the ambivalence that runs throughout Zoshchenko's work of the 1920s. But how does the notion of an ambivalent attitude to the narrator square with the tension we have been broadly describing as that between interpretation and experience? They are two related aspects of the epistemological uncertainty that lies at the heart of the Zoshchenko short story. It is not so much a question of deciding for or against the narrator, but of deciding which to trust: the narrator's description of his 
experience or his interpretation of it. As we have seen, this is a tension inherent in the feuilleton's fact/generalisation distinction, and one that Zoshchenko was to exploit beyond the bounds of what was habitual in that form. Nevertheless, this is not solely a question of language and genre, i.e. of parody, but also one of point of view and hence of irony. Since the reader must decide whether the text supplies a coherent or convincing interpretation of the concrete experience also portrayed there.

Yet, as I have attempted to show, Zoshchenko's stories are not ironic if we agree with his narrators' interpretations of their experience. Even if we see a discrepancy, that discrepancy is often as tragic as it is comic. Zoshchenko went to some lengths to ensure that readers perceived a choice as to how to interpret the stories.

Contemporaries commented how seriously Zoshchenko read his own stories and how he especially rated straight-faced performances of his work, such as Iakhontov's. It seems to me that this reveals a desire to make the reader feel the serious appeal for sympathy in them and not simply burst into unreflecting laughter at the narrator's expense. ${ }^{11}$ The great comic writer wanted to ensure that readers were free to see the serious side, even if fleetingly, and to attempt to fit reality to the narrator's scale of values, even if unsuccessfully. Indeed, in 'Kak ia rabotaiu' (1930), he even went so far as to insist that the serious side of his work was its most important aspect, and that he never intended to make people laugh:

Их [маленькие рассказы] называют юмористическими. Собственно, это не совсем правильно. Они не юмористические. Под юмористическим мы понимаем рассказы, написанные ради того, чтобы носмешить. Но я писал не для того, чтобы посмешить; это складывалось помимо себя - это особенность моей работы. (Uvazhaemye grazhdane, p. 590)

Similarly, in 'Avtobiografiia' (1932), Zoshchenko blames the humorous effect on the critics: 
Мне много пришлось поработать над языхом. Весь синтахсис надо было круто менять, чтобы сделать литературную вещь простой и доступной новым читателям. Доказательством того, что я не ошибся, были очень высохие тиражи моих книг. Стало быть, язых, который я взял и который, на первых порах, казался критике смешным и нарочно исковерханным, был, в сущности, чрезвычайно простым и естественным. (Uvazhaemye grazhdane, p. 592)

These claims seem extreme, and it is hard to believe that Zoshchenko intended none of the humour of his stories, but they make more sense when we relate it to his 1944 article, 'O komicheskom v proizvedeniiakh Chekhova'. ${ }^{12}$ Here he argues that there are two sorts of laughter: humorous laughter that affirms and is trivial, and satirical laughter that is critical of society. ${ }^{13}$ Chekhov, he argues, was defined by critics of his time as simply funny in a neutral way in order to dampen the satirical force of his stories, in order to let the targets of his satire off the hook. In the two previous quotations Zoshchenko stresses that his own intention in writing his short stories was not to produce humorous stories and not to make people laugh. Implicitly, his intention was to make them see their faults and the faults of the society in which they live. In these two works of the early 1930s, he perceives the two intentions as mutually exclusive. Moreover, in contrast to the later article on Chekhov, he sees only one kind of laughter: the trivial, humorous sort. However, the essential argument is unchanged: apparently comic works, be they his or those of Chekhov, are far more serious than is usually thought. Humour is no laughing matter.

Here Zoshchenko rejoins the greatest of satirical or comic writers, such as Swift, who could not understand how the people whose vices he had wanted to expose laughed and were neither ashamed nor reformed: 'The chief end I propose to my self in all my labours is to vex the world rather than to divert it. ${ }^{14}$ This is true also of Gogol', who was particularly concerned that the public misunderstood his works. He even explored this question in the mayor's speech from 'Revizor': 'Chemu smeetes'? 
Nad soboiu smeetes'! ${ }^{15}$ This was appositely echoed in the title of a 1928 selection of Zoshchenko's stories: 'Nad kem smeetes'?'

In this 1944 article, Zoshchenko uses a discussion of Chekhov to write about problems in the reception of his own comic art. Nevertheless, there are also significant and instructive contrasts between the two writers. Unlike Chekhov, Zoshchenko never claimed that he had attempted to suspend judgement because he believed this to be the writer's mission or moral duty. ${ }^{16}$ Yet the effect of the Soviet writer's contradictory statements about literature is to demand that we use our own powers of judgement rather than trust those of the author. Likewise, the effect of his skaz narratives is to remove the possibility of certain knowledge and to demand that we distrust the narrator's conclusions and be willing, if need be, to supply our own instead. A stance such as Chekhov's would have been almost impossible in the USSR of the 1920s, when public professions of loyalty were required from writers. Zoshchenko's contradictory views, proffered when goaded by hostile criticism into defending the way in which he wrote, achieve something similar by refusing to give straight-forward or self-identically definitive answers. This contradictory view of his art that we find in his articles has itself been deemed irrelevant by critics of all political and critical hues in search of a univalent and definitive Zoshchenko. These writings become a powerful tool for exegesis only when seen through an understanding of the dual possibilities of skaz and hence of Zoshchenko's thought and art.

\section{Zoshchenko's Development: The End of Ambivalence}

Zoshchenko began to realise that his works produced an ambivalent and humorous effect that he himself could not control ('Avtobiografiia', Uvazhaemye grazhdane, p. 592). This was what Zoshchenko eventually termed irony. It seems to me that this irony was an uncertainty, a doubt and an ambivalence which was the product of his contradictory intentions, whereby the reader could not be sure of the meaning of any given statement or any given story. This ambivalence, expressed in the contradictions of his early short stories, creates the openness that is a fundamental characteristic of his best short stories, most ci which were written in the 1920s. It is this, which 
distinguishes them from his later, irony-free, straightforward work, be it his less celebrated documentary works or Pered voskhodom solntsa.

With the intensification of criticism of him from 1927, in a political climate where ideological conformity and loyalty was demanded of artists and writers, it became increasingly desirable to rid his work of such unintended irony. It came to worry him; he began to see it as an illness, and strove to cure himself of it even at the cost of his art. Chukovskii writes in his memoirs that in the early 1930s, Zoshchenko repeatedly complained about his irony as if it was an illness:

Он говорил, что ему отвратителен его иронический тон, который так нравится литературным гурманам, что вообще он считает иронию пороком, тяжелой болезнью, от которой ему, писателю, необходимо лечиться. Потому что для демохратического читателя, $\mathbf{x}$ хоторому он и обращается со своими писаниями, превыше всего - здоровая ясность и цельность души, простота, добросердечное и радостное понятие мира. ${ }^{17}$

Chukovskii's account also resembles the way in which Zoshchenko claimed that the humour in his stories was unintentional. ${ }^{18}$ People like Chukovskii treasured the ambivalence of Zoshchenko's work, as we do now, while most of the readers whose letters he published in Pis'ma k pisateliu saw Zoshchenko as something of a moral teacher. Zoshchenko himself cherished such readers and saw ambivalence as a curse to be shaken it off in favour of optimistic and cheerful simplicity. Tragically he succeeded. His success also destroyed the delicate balance of his short stories, making them one-sidedly sincere or crudely hostile and inferior in quality to his earlier work. The balance of the ambivalence was upset, and the stories were less and less written in the skaz style.

Nevertheless, there are many common elements between the stories of the $1920 \mathrm{~s}$ and the later works, which permit us to see precursors to later Zoshchenko's development. This is particularly true of the relation between broad, ambitious interpretation and concrete documentary evidence in the narrative. Throughout 
Vozvrashchennaia molodost' and Golubaia kniga the narrative fails to corroborate fully the interpretive sweep. In the former there is a tension between the book's broad thesis and its scientific notes on one hand, and the narrative provided to prove this thesis on the other. In Golubaia kniga the broad historical framework of vice resolved by socialism is in fact contradicted by the stories provided to prove that view. In both cases the narration complicates the stated didactic aim. Nevertheless, both works give greater weight and power to an overarching interpretation than is usual in the stories of the 1920 s, a fact exemplified in the use of a standardised, reliable form of narration instead of skaz. The same pernicious tendency can be observed in Zoshchenko's later short stories.

Interpretation reaches its apogee in Zoshchenko's work with Pered voskhodom solntsa. Here evidence is dovetailed to fit the predetermined interpretive framework. The result is a rigidly determinist vision in which appetites and fears ingrained in childhood determine subsequent human existence. Pered voskhodom solntsa is a confession of faith in a rational psychology, in optimism as a path to health, but those claims are counterbalanced with none of the qualifications or conflicting evidence we saw in Zoshchenko's early work. In the short stories of the 1920s there was often an irony at the expense of psychological accounts of human existence. This is exemplified by 'Nervnye liudi' (1925) (SS I, pp. 322-24), in which the psychological account of the characters' violent conduct is counterbalanced by suggestions that their behaviour is due to their squalor and selfishness. Such balance and such laughter are banished from Zoshchenko's later psychological account of human behaviour. In place of the old comic power, there is a sober sterility and a scientific laconism. Where the early works were garrulous, fallible and contradictory, Pered voskhodom solntsa is economic, authoritative and monolithic. Where there was once an ambivalence that left the reader in a state of uncertainty, full of questions, there is now clarity, a definitive answer presenting itself as an end to questions.

The clarity of this work, and its scandalous treatment at the hands of Soviet criticism and the censor, have made it an attractive place for recent critics to start an analysis of Zoshchenko's work. Certainly the project of understanding the whole of 
Zoshchenko's oeuvre is an important one, and recent critics are right to react against the tendency to see Zoshchenko simply as a satirist relevant solely to Soviet life. However, beginning an analysis of Zoshchenko, as Zholkovsky and Scatton have done, with an interpretive framework derived from the certainties and univalencies of Pered voskhodom solntsa, is to risk subordinating the rest of Zoshchenko's work to it. $^{19}$ Attempts to stress the continuity of Zoshchenko's creative output throughout his life tend to subordinate the genius and complex irony of the short stories to the mediocrity of the other work and unqualified sincerity of Pered voskhodom solntsa. Moreover, they fail to explain convincingly how a comic vision of the world becomes one of humourless piety. Such an analysis is likely to lose sight of the fact that it is the contradictions, the humour, and their source in Zoshchenko's narrative technique that constitute their greatness. With the resolution of these contradictions, the humour disappears.

This is why Zoshchenko's comic short stories of the 1920s are irreconcilably in conflict with the later work in general and Pered voskhom solntsa in particular: it resolves the conflict at the heart of his earlier work. That his greatest works are short must not serve as a barrier to adequate appreciation of their extraordinary value. Their size is part of their insight into the fragmented nature of experience: we may as well condemn a haiku or an Ungaretti poem for being short. Their underlying vision of an unresolved tension between the striving to interpret and find coherence, on one hand, and the fragmented nature of experience and life, on the other, can only be perceived in its full strength by separating them from the later work, not subordinating them to it. 


\section{Conclusion}

In striving to produce a coherent, readable account of Zoshchenko's short stories, commentators have often resolved their contradictions. Many critics have gone to great lengths to tidy up or explain away the fragmented form of Zoshchenko's skaz narratives as an encyclopaedia, a prologue or part one of an extended narrative. I hope to have shown that we can gain greater insight into Zoshchenko's short stories if we stop regarding their narrative form as an obstacle to understanding Zoshchenko's underlying purpose or world-view, but rather see that form as the irreducible embodiment of an ambivalent world-view. Zoshchenko drew on a number of genres and sources for his art, and transformed them by adding a skaz narrative, thereby creating an original form. This form is his supreme achievement and guarantees the stories' lasting appeal.

The problem of the relation between Zoshchenko and skaz is that critics tend to concentrate on analysing Zoshchenko and adopt a simplified view of skaz. In consequence Zoshchenko is forced to comply with a narrow view of skaz as parody. By redefining skaz we are better able to understand Zoshchenko. Whatever the context in which we intend to place Zoshchenko, his skaz narrative form is of the greatest importance. Skaz too reached its zenith with Zoshchenko. The tendency towards the fragment and the unstable status of narrative authority in skaz were extended to their utmost in an ideal epoch, the aftermath of a revolution, by an ideal exponent, a man racked by self-doubt. The fragmentation and confusion of Russian society in the $1920 \mathrm{~s}$ created an atmosphere of unstable authority that is echoed by the structure of Zoshchenko's narratives. For this reason it has been necessary to combine an analysis of skaz with an investigation of Zoshchenko.

The analysis of skaz and Zoshchenko has at the same time provided us with a fascinating and instructive example of how text and author influence and are influenced by each other. Authors make their own meaning, but not in an original language or unprecedented forms. Form has its own philosophy, but that philosophy is not completely autonomous. It interacts with its author and with its reader: meaning is 
not solely a reader-text relation. Zoshchenko's views are relevant to an understanding of his work. To discount them in the pursuit of a unifying vision of him is a homogenising and impoverishing interpretation of the contradictory evidence of his work.

The term skaz was initially introduced by the Formalists to further the argument that meaning is textual and not authorial. Ultimately then, it is an irony (of fate) that I have come to believe, and have attempted to demonstrate, that authorial intentions, insofar as we can know them, are relevant to our understanding of works of fiction. The continued relevance of $s k a z$ as a term of literary criticism can only be ensured by insisting on Bakhtin's distinction between parodic and stylised skaz: a distinction that can only be maintained by reference to authorial intention. I do not see the resurrection of the author as an attempt to turn the clock back, but rather as an effort to establish balance in the debate as to what determines a text's meaning.

Moreover, I hope that in future skaz will be more consistently related to other modes of quotation such as parody, irony, stylisation and pastiche. Doing so will throw more light on skaz and will, I suggest, further illuminate such practices. Seen in this light, skaz becomes highly relevant to influential present-day intellectual currents, such as the thought of Derrida. The nature of this thesis, its combination of an examination of the skaz narrative technique with a study of its use by a given writer, has meant that I have not been able to explore such connections. This structure has also meant me touching upon or raising certain issues regarding the $1920 \mathrm{~s}$ and Zoshchenko without being able to investigate them in full. These questions include the relation of Zoshchenko's work to that of other satirical writers of his time and a comparison of his documentary practices with those of the left-art movement. However, the study of these and all matters relating to Zoshchenko is at present hampered by the legal obstacles preventing the publication of an adequate collected edition of his works. Consequently my thesis and any research on Zoshchenko raises questions of textology that may have to wait for copyright to expire on Zoshchenko's works, in 2008 , before they can be treated systematically. I hope that my thesis has 
enhanced the reader's appreciation of Zoshchenko sufficiently to have encouraged him or her to address these issues.

Finally, although it has been my intention in this thesis to stress the fragmented and contradictory nature of Zoshchenko's art, I hope to have avoided reproducing the fragmentary and contradictory nature of my subject matter. Whether or not I have successfully consummated this authorial intention is for the reader to judge. 


\section{Notes}

\section{Chapter I: Introduction and Literature Review}

1 The term siuzhetnaia ironiia was first used with regard to Zoshchenko by Anna Beskina in Anna Beskina, 'Litso i maska Mikhaila Zoshchenko', Literaturnyi kritik, 1 (1935), 107-31 and 2 (1935), $59-91$.

2 There are many stories where the narrator's speech achieves the opposite of what he himself intended. 'Rech' o vziatke', ‘Amerikantsy', 'Peredovoi chelovek', 'Semeinoe schast'e', ‘Agitator', 'Chelovek bez predrassudkov' are but a few examples.

3 Anatolii Starkov, Iumor Zoshchenko, Moscow: Khudozhestvennaia literatura, 1974, p. 35. See also Anatolii Starkov, Mikhail Zoshchenko: sud ba khudozhnika, Moscow: Sovetskii pisatel', 1990.

4 V. D. Levin in particular stresses that certain deviations from the literary norm are attempts to redefine it. However, he too is unwilling to use the term skaz for such serious works of literature. This, it seems to me, is a further indication of the pervasive influence of the definition of skaz as solely a form of parody. See V. D. Levin, “"Neklassicheskie” tipy povestvovaniia nachala XX veka $\mathrm{v}$ istorii russkogo literaturnogo iazyka', Slavica Hierosolymitana, 5-6 (1981), 245-75.

5 The majority of Zoshchenko's critics haveseen Zoshchenko as opposed to his narrator in one way or another. Soviet variants of this theory include Beskina, 'Litso i maska Mikhaila Zoshchenko'; Kornei Chukovskii, 'Iz vospominanii', in Iurii Tomashevskii (ed.), Vospominaniia o Mikhaile Zoshchenko, St Petersburg: Khudozhestvennaia literatura, 1995, pp. 29-88; Leonid Ershov, Sovetskaia satiricheskaia proza 20-kh godov, Moscow-Leningrad: Akademiia Nauk, 1960; Leonid Ershov, M. Zoshchenko i satiricheskaia proza 20-40-kh godov, Leningrad: Nauka, 1973; I. Eventov, 'Iumor Mikhaila Zoshchenko', Neva, 10 (1968), 166-72; Dmitrii Moldavskii, Mikhail Zoshchenko: ocherk tvorchestva, Leningrad: Sovetskii pisatel’, 1977; E. G. Mushchenko, V. P. Skobelev, L. E. Kroichik, Poetika Skaza, Voronezh: Izd. Voronezhskogo gosudarstvennogo universiteta, 1978; Mikhail Slonimskii, 'Mikhail Zoshchenko', in Vospominaniia o Mikhaile Zoshchenko, pp. 89-108; Tsezar' Vol'pe, Kniga o Zoshchenko [1940], repr. in Iskusstvo nepokhozhesti, Moscow: Sovetskii pisatel’, 1991, pp. 141-316; Evgeniia Zhurbina, 'Mikhail Zoshchenko,' in Mikhail Zoshchenko, Sobranie sochinenii, 6 vols, Leningrad and Moscow: Priboi-GIKhL, 1929-32, I, pp. 1-20; Western or émigré variants include Jacqueline Decter Cukierman, 'Mixail Zoščenko's Rasskazy and Povesti 
of the 1920s: A Study in Genre Evolution', unpublished doctoral thesis, University of Michigan, 1978; Victor Erlich, 'The Masks of Mikhail Zoshchenko', Stanford Slavic Studies , 4/2 (1992), 15776; Carol Schrier Katowitz, 'A Study of the Character and Function of the Narrator-Participant in Selected Short Stories of Mixail Zoščenko', unpublished doctoral thesis, University of Pennsylvania, 1972; Mikhail [Michael Boris] Kreps, 'Mixail Zoščenko as Humorist and Satirist: A Structural Approach', unpublished doctoral thesis, Berkeley: University of California, 1981; Mikhail Kreps, Tekhnika komicheskogo u Zoshchenko, Benson VT: Chalidze, 1986; A. B. Murphy, Mikhail Zoshchenko: A Literary Profile, Oxford: W. A. Meeuws, 1981; Viktor Sven, Chei drug i chei vrag Mikhail Zoshchenko? Munich: Izd. Tsentr. ob"edineniia politicheskikh emigrantov iz SSSR (TSOPE), 1958; Irwin Titunik, 'Mixail Zoščenko and the Problem of Skaz', California Slavic Studies, 4 (1971), 83-96; Vera Von Wiren-Garczynski, 'The Russian Language in the Immediate Post-Revolutionary Period (1919-1928) and its Literary Stylization in the Fiction of Mixail Zoščenko', unpublished doctoral thesis, New York University, 1965.

6 Iurii Shcheglov, 'Mir Mikhaila Zoshchenko', Wiener Slawistischer Almanach, 7 (1981), 109-54; and Iurii Shcheglov, 'Entsiklopediia nekul'turnosti: Zoshchenko: rasskazy 1920-kh godov i “Golubaia kniga"', in Alexander Zholkovsky and Iurii Shcheglov, Mir avtora i struktura teksta: stat 'i o russkoi literature, Tenafly NJ: Hermitage, 1986, 53-84.

7 See, for example, Georgii Gorbachev, Sovremennaia russkaia literatura, 3rd edn, Leningrad; Moscow: Gosizdat khudozhestvennoi literatury, 1931. See also Georgii Gorbachev, Ocherki sovremennoi russkoi literatury, 2nd edn, Leningrad: Gosizdat, 1924.

8 Slonimskii, 'Mikhail Zoshchenko', p. 103.

9 Benedikt Sarnov, Prishestvie kapitana Lebiadkina (Sluchai Zoshchenko), Moscow: Pik Rik; Kul'tura, 1993. Sarnov's description of Zoshchenko's character coincides substantially with that of Shcheglov. However, Sarnov's evaluation of Zoshchenko's relation to it differs from Shcheglov's. 10 Sarnov, Prishestvie kapitana Lebiadkina, p. 160-61.

11 Alexander Zholkovsky, Mikhail Zoshchenko: poetika nedoveriia, Moscow: Shkola, 1999. (I shall refer throughout to this critic by the anglicised variant of his name under which his English language works are published). Andrei Siniavskii also attempts to do this. Andrei Siniavskii, 'Mify Mikhaila Zoshchenko', Voprosy literatury, 2 (1989), 50-67. In his earlier work Zholkovsky also argues for the identity of the author's and the narrator's striving towards simplicity. Alexander Zholkovsky, 
Text Counter Text: Rereadings in Russian Literary History, Stanford CA: Stanford University Press, 1994, pp. 41-52.

12 Alexander Zholkovsky, “'What is the Author Trying to Say With His Artistic Work?” Rereading Zoshchenko's Oeuvre', Slavonic and East European Journal, 40/3 (Fall 1996), 458-74 (p. 459).

13 Alexander Zholkovsky, 'K reinterpretatsii poetiki Mikhaila Zoshchenko (“Entsiklopediia strakha” $\mathrm{i}$ ideinaia struktura rasskaza “Dushevnaia prostota")', Izvestiia Akademii Nauk SSSR: Seriia literatury i iazyka, 54/5 (1995), 50-60. Similarly, Zholkovsky argues that Gogol"s skaz is a result of his unstable sense of identity. But here too it is also possible to see the roots of Gogol"s skaz in cultural factors such as the narrative forms of Romanticism, suited to the expression of irony. Zholkovsky, Text Counter Text, p. 20.

14 Zholkovsky states this objective in its clearest form in Alexander Zholkovsky, ' $\mathrm{K}$ pereosmysleniiu kanona: sovetskie klassiki-nonkonformisty v postsovetskoi perspektive', Novoe literaturnoe obozrenie, 29 (1998), 55-68.

15 Ibid., p. 60 .

16 Linda Hart Scatton, Mikhail Zoshchenko: Evolution of a Writer, Cambridge: Cambridge University Press, 1993, p. 10

17 Marietta Chudakova, Poetika Mikhaila Zoshchenko, Moscow: Nauka, 1979, p. 88.

18 Cathy Popkin, The Pragmatics of Insignificance: Chekhov, Zoshchenko, Gogol, Stanford CA: Stanford University Press, 1993, p. 111.

19 'Gor 'kii- Zoshchenko' [September, 1930], in Gor kii i sovetskie pisateli: neizdannaia perepiska, Literaturnoe nasledstvo, LXX, Moscow: Izd. Akademii Nauk SSSR, 1963, pp. 157-68 (p. 159).

20 Chukovskii, 'Iz vospominanii', p. 38.

21 Galina Belaia, Zakonomernosti stilevogo razvitiia sovetskoi prozy 20-kh godov, Moscow: Nauka, 1977, p. 77.

22 Ibid., p. 80.

23 Galina Belaia, 'Eksistentsial'naia problematika tvorchestva M. Zoshchenko', Literaturnoe obozrenie, 1 (249) (1995), 4-13.

24 Mikhail Zoshchenko, Nervous People and Other Satires, ed. and intro. by Hugh McLean, tr. Maria Gordon and Hugh McLean, London: Gollancz, 1963, pp. xiii-xiv. 
25 M. Keith Booker \& Dubravka Juraga,'Language, Genre and Satire in the Works of Mikhail Zoshchenko', in M. Keith Booker \& Dubravka Juraga, Bakhtin, Stalin and Modern Russian Fiction: Carnival, Dialogism and History, Westport CT: Greenwood Press, 1995, pp. 83-102.

26 V. Novikov, 'O meste Zoshchenko v russkoi literature (Predshestvenniki i posledovateli ot Daniila Zatochnika do Mikhaila Zvanetskogo)', Literaturnoe obozrenie , 1 (249) (1995), 25-27.

27 Ibid., p. 25.

28 Ibid., p. 26.

29 Gregory Steven Carleton, 'Problems of Text and Reception: Mixail Zoščenko', unpublished doctoral thesis, University of Michigan, 1992, p. 2. This thesis forms the basis of his later book, Gregory Steven Carleton, The Politics of Reception: Critical Constructions of Mikhail Zoshchenko, Evanston IL: Northwestern University Press, 1998.

30 Carleton, 'Problems of Text and Reception: Mixail Zoščenko', p. 227.

31 Ibid., p. 15.

32 Zhurbina, 'Mikhail Zoshchenko', p. 2. 


\section{Chapter II: Definitions of Skaz}

1 Vladimir Dal', Tolkovyi slovar' zhivogo velikorusskogo iazyka, 4 vols, St Petersburg: Vol’ff, 1880-82; repr. Moscow: Russkii iazyk, 1981-82.

2 The authors of Poetika skaza argue that critics of the early part of the century took an interest in skaz as a consequence of social changes that enhanced the role of the spoken word, the widespread use of colloquial language in literature and a growing concern in linguistics with the study of dialects and the spoken word. E. G. Mushchenko et al., Poetika Skaza.

3 Boris Eikhenbaum, 'Illiuziia skaza' [1918], in Jurij Striedter (ed.), Texte der Russischen Formalisten, Munich: Wilhelm Fink, 1969, I, pp. 160-66; tr.: 'The Illusion of Skaz', tr. Martin P. Rice, Russian Literature Triquarterly, 12 (1975), 233-36.

4 Even Turgenev, an author one hardly associates with skaz, has stories related by an oral narrator in a literary style. Indeed, characters who speak language of a conversational register abound in examples of literature that Eikhenbaum would not call skaz.

5 In an article published seven years later, 'Leskov i sovremennaia proza', Eikhenbaum briefly outlines the later Formalist view of the dominant through the example of skaz. Any element of the material, he contends, can dominate the others. The earlier notion of skaz as a principle in the work seems to prefigure this. Boris Eikhenbaum, 'Leskov i sovremennaia proza' [1925], in Jurij Striedter (ed.), Texte der Russischen Formalisten, Munich: Wilhelm Fink, 1969, I, pp. 208-42.

6 Boris Eikhenbaum, 'Kak sdelana "Shinel”" Gogolia' [1919], in Jurij Striedter (ed.), Texte der Russischen Formalisten, Munich: Wilhelm Fink, 1969, I, pp. 122-58; tr.: 'How Gogol's “Overcoat" is Made', in Gogol From the Twentieth Century: Eleven Essays, ed. and tr. Robert Maguire, Englewood Cliffs NJ: Prentice Hall, 1967, pp. 267-92. Titunik has rightly pointed out that Eikhenbaum writes of the 'illısion' of skaz, but does not tell us what real skaz is. Irwin Titunik, 'The Problem of $S k a z$ in Russiaı I.iterature', unpublished doctoral thesis, Berkeley: The University of California, 1963.

7 Eikhenbaum, 'Kak sdelana "Shinel”" Gogolia', p. 128.

8 It should be noted that 'predstavlenie' could also mean performance. This sense is also relevant to the idea of oral speech as an unrepeatable event. See the discussion of Ong, later in this chapter.

9 Eikhenbaum, 'Leskov i sovremennaia proza', p. 218.

10 This argument is expressed especially in Eikhenbaum, 'Illiuziia skaza'. 
11 Walter J. Ong, Orality and Literacy: The Technologizing of the Word, London: Routledge, 1990.

12 Eikhenbaum, 'Kak sdelana "Shinel”" Gogolia', p. 124.

13 Ong, however, stresses that drama is a form that is first written and then performed, and therefore cannot be seen as oral, though it is undoubtedly performed: Ong, Orality and Literacy, p. 47. The authors of Poetika skaza also argue that skaz appears to be improvised or created in our presence. There appears to be a direct contact between the speaker and the listener, since skaz is oriented towards an audience, who are expected to be sympathetic: Mushchenko et al., Poetika skaza.

14 Titunik, 'The Problem of Skaz in Russian Literature'. See below, later in this chapter.

15 As we shall see, Leskov does have more rounded characters in his skaz narratives. In this respect he is remarkable among skaz writers, and an example of an adaptation of skaz to the poetics of the Realist novel, so dominant in his era.

16 Eikhenbaum, 'Illiuziia skaza', p. 162.

17 Ong, Orality and Literacy, p. 165.

18 Ibid., p. 165.

19 In part this is because the subject matter is not the heroic past of the internally coherent folkloric world, but very recent events that have occurred in a world altered by writing and modernity.

20 Plato's preference for the spoken word and anxieties about the written word in Phaedrus are articulated in writing by a philosopher whose theory of visually perceived forms presented an extremely visual conception of truth.

21 Karen Ann Hohne, 'Skaz and Babel"s Konarmija', unpublished doctoral thesis, Indiana University, 1986.

22 Viktor Vinogradov, 'Problema skaza v stilistike' [1925], in Striedter (ed.), Texte der Russischen Formalisten, I, pp. 168-206 (p. 176.); tr.: 'The Problem of Skaz in Stylistics,' tr. Martin P. Rice, Russian Literature Triquarterly, 12 (1975), 237-250 (p. 239).

23 It should be noted that Vinogradov also introduces seemingly unworkable and irrelevant terminology such as the notion of $s k a z$ as a monologue. This is adequately criticised by Titunik, 'The Problem of Skaz in Russian Literature', p. 15. In later revisions of his theory of skaz, Vinogradov plays down the term and offers a more cogent version of his theory: Viktor Vinogradov, 'Problema obraza avtora v khudozhestvennoi literature', in O teorii khudozhestvennoi prozy, Msocow: Vysshaia shkola, 1971, pp. 105-211. 
24 Vinogradov, 'Problema skaza v stilistike', p. 190.

25 Mikhail Bakhtin, Problemy tvorchestva Dostoevskogo, Leningrad, Priboi, 1929, pp. 81-88; repr. Moscow: Alkonost, 1994. English translation of the revised edition: Mikhail Bakhtin, Problems of Dostoevsky's Poetics, ed. and tr. Caryl Emerson with an introduction by Wayne C. Booth, Minneapolis: University of Minnesota Press, 1984, pp. 189-95. Some critics, such as Mushchenko $e t$ al., the authors of Poetika skaza, do not see Bakhtin's and Eikhenbaum's definitions as in conflict.

26 Eikhenbaum, 'Illiuziia skaza', p. 160.

27 In describing Eikhenbaum, Pechey overstates the case: 'Formalism sees in skaz the pure presence of speaking uncontaminated by writing and anterior to all institution.' Graham Pechey, 'Bakhtin, Marxism and Post-Structuralism', in F. Barker et al. (eds), Literature, Politics and Theory: Papers from the Essex Conference 1976-84, London: Methuen, 1986, p.118. Interestingly, Walter Benjamin takes a similar view in his article on Leskov. Walter Benjamin, 'The Storyteller: Reflections on the Works of Nikolai Leskov', in Walter Benjamin, Illuminations, ed. Hannah Arendt, tr. Harry Zohn, London: Fontana, 1992, pp. 83-107.

28 Mushchenko et al., Poetika skaza, p. 24.

29 'But the world of primary orality cannot be understood (...) except in retrospect, for it had no way of reflecting on itself.' Walter Ong, 'From Mimesis to Irony: Writing and Print as Integument of Voice', in Interfaces of the Word: Studies in the Evolution of Consciousness and Culture, Ithaca NY: Cornell University Press, 1971, p. 299.

30 Bol'shaia sovetskaia entsiklopediia, 2nd edn, Moscow: Ogiz, 1949-58, s.v. 'skaz'.

31 Felix J. Oinas, 'Folkloric Activities and Scholarship in Russia', Essays on Russian Folklore and Mythology, Columbus OH: Slavica, 1985, p. 141.

32 Iurii Sokolov, Russkii fol klor, Moscow: Uchpedgiz, 1938, p. 508.

33 See below for sources of this confusion in Leskov's own work. The entry on skaz by Chudakov and Chistov in the third edition of the Soviet Encyclopedia breaks down skaz into the folkloric and the literary. Bol'shaia sovetskain entsiklopediia, 3rd edn, Moscow: Sovetskaia entsiklopediia, 1970-78, s.v. 'skaz'.

34 Frank J. Miller, Folklore for Stalin: Russian Folklore and Pseudo Folklore of the Stalin Era, New York: M. E. Sharpe, 1990, p. 19. 
35 In an investigation into the boundaries between folklore and what we call folkloric stylisations, Albert Lord argued that the important distinction between a literary retelling of a folktale and a traditional folktale is the contrasting process of composition and transmission: a folktale is composed and transmitted orally, for a traditional audience, whereas a folkloric stylisation is composed and transmitted in written form for a literate readership. Lord accepts that this process begins when a collector first transcribes a tale, but distinguishes this from folkloric stylisation such as that of Italo Calvino's Italian Folktales. For Lord, then, the distinction between style and stylisation is made by reference to the context rather than on solely textual criteria. Albert Bates Lord 'The Transitional Text', in Albert Bates Lord, The Singer Resumes the Tale, ed. Mary Louise Lord, Ithaca NY: Cornell University Press, 1995, pp. 212-37.

36 N. I. Rybakov, 'K probleme skaza v khudozhestvennoi literature', Uchenye zapiski Moskovskogo pedagogicheskogo instituta, 485 (1972), 80-97.

37 Ibid., p. 83.

38 Ibid., p. 83.

39 A parallel debate has been recently renewed as to whether the poetry of Esenin is a development of folklore or a stylisation of it. These views are briefly reviewed in Ronald Vroon, 'The Garden in Russian Modernism', Revue des études slaves, 69/1-2 (1997), 135-149 (pp. 135-36). Nikolai Fed' sees Esenin as simply folkloric. Nikolai Fed', 'Russkii literaturnyi skaz', in Zhanry $v$ meniaiushchemsia mire, Moscow: Sovetskaia Rossiia, 1989, pp. 238-524. This is indicative of this critic's unwillingness to distinguish stylisation and folklore proper.

40 Rybakov, 'K probleme skaza v khudozhestvennoi literature’, p. 83.

41 Ibid., p. 97.

42 Fed' also sees Bazhov as the most accomplished practitioner of skaz: Fed', 'Russkii literaturnyi skaz', passim.

43 Sokolov refers to him as a collector of folklore. Sokolov, Russkii fol klor, p. 439. Bazhov worked for the letters column of Krest ianskaia gazeta throughout the 1920s (p. 410). It seems possible, given the link between Zoshchenko's skaz and the letter form, that this work enabled him to write his later skaz stories. See the brief biography of Bazhov in Pavel Bazhov, Malakhitovaia shkatulka, ed. 1. Skorino, Moscow: Sovetskii pisatel’, 1947, p. 410.

44 Fed', 'Russkii literaturnyi skaz', p. 248. 
45 Ibid., p. 249.

46 Ibid., p. 377.

47 Ibid., p. 433.

48 Christopher English has also argued against the attempt by scholars such as Rybakov to equate all uses of skaz with the presence of folkloric influences. Christopher English, "'Schalk Lourens and Ivan Flyagin" : A Study of the Skaz Mode of Narration with Reference to the Stories of Leskov and Bosman', in Henrietta Mondry (ed.), The Waking Sphinx: South African Essays on Russian Culture, Johannesburg: University of the Witwatersrand, 1989, pp. 145-60.

49 Though Vinogradov does not develop the question of the narrator in 'Problema skaza v stilistike', in fact he does it in his later work, for example in 'Obraz avtora v khudozhestvennoi literature'.

Bakhtin's study predates the latter, and develops the idea of the narrator into an important part of his theory of parody.

50 Bakhtin, Problemy tvorchestva Dostoevskogo, p. 84.

51 Titunik, 'The Problem of Skaz in Russian Literature', p. 40.

52 The notion of skaz as deviation from a written norm is a widespread one. Good examples of it are Hans Günther, 'Zur Semantik und Funktion des Skaz bei M. Zoščenko', in Gernot Erler et al. (eds), Von der Revolution zum Schrifftsteller Kongreß, Berlin: OstEuropa Institut, 1979, 326-53; and Robert Hodel, Betrachtungen zum Skaz bei N. S. Leskov und Dragoslav Mihailović, Bern: Peter Lang, 1994, pp. 16-17. Levin and Natal'ia Kozhevnikova similarly use the idea of a normative language from which skaz deviates. This question desicussed below, later in this chapter and in Chapter III. Ann Banfield also argues that skaz is by its nature not authoritative. Ann Banfield, Unspeakable Sentences: Narration and Representation in the Language of Fiction, Boston MA: Routledge and Kegan Paul, 1982, p. 252.

53 Vladimir Zakharov, Sistema zhanrov Dostoevskogo: tipologiia i poetika, Leningrad: Izd. Leningradskogo universiteta, 1985.

54 Zakharov opposes rasskazchik, what narrative theory would call the narrator, and povestvovatel, what narrative theory would call the focaliser. Note that rasskaz and povest ${ }^{\prime}$ are normally distinguished on grounds of Iength, with the rasskaz as the smaller. For example, see Ivan Volkov, Teoriia literatury: uchebnoe posobie dlia studentov i prepodovatelei, Moscow: Prosveshchenie; 
Vlados, 1995, p. 134. Zakharov's notion of rasskaz as tending towards skaz finds support in Bakhtin's Problemy tvorchestva Dostoevskogo, p. 83.

55 Zakharov, Sistema zhanrov Dostoevskogo, p. 56.

56 Ibid., p. 42 (note). Zakharov claims that the authors of Poetika skaza run counter to the traditions of definition of skaz in Soviet criticism. This is ungenerous and untrue, since their definiton finds support in a number of the classic analyses of skaz, not least of which is Bakhtin's Problemy tvorchestva Dostoevskogo, which Zakharov himself refers to.

57 However, as I argue below, in Chapter III, Dostoevskii does this for ideological and psychological characterisation.

58 Klawa Nepscha Thresher, 'Narration in Selected Short Works by Nikolaj Gogol': An Investigation into Multiple Narrative Modes and the Presence of Skaz', unpublished doctoral thesis, University of Wisconsin, 1992.

59 Bakhtin, Problemy tvorchestva Dostoevskogo, p. 84.

60 Eikhenbaum, 'Leskov i sovremennaia proza', p. 230. Vinogradov noted that skaz introduces “'uncanonised”, extra-literary linguistic forms': Vinogradov, 'Problema skaza v stilistike', p. 200.

This is slightly different to the introduction of the language of the people, and is closer to the Formalist notion of literary evolution as incorporating the extra-literary in order to form new genres.

61 Mushchenko et al., Poetika skaza, p. 9.

62 Ibid., p. 17.

63 See below, Chapter III.

64 Mushchenko et al., Poetika skaza, p. 29.

65 The focus of Levin's article is Belyi, Remizov and Rozanov, who are not attempting to bring in a narrator with a socially other $\epsilon$ xtra-literary language, but to revolutionise literary language with the introduction of elements of the oral. They are contrasted with the language of skaz, particularly that of Leskov and Gogol', who are seen as reacting to classical prose style, rather than, like these writers, attempting to create a new style. Levin, "'Neklassicheskie" tipy povestvovaniia'.

$66 \mathrm{He}$ is more explicit in an earlier work: V. D. Levin, 'Literaturnyi iazyk i khudozhestvennoe povestvovanie', in V. D. Levin (ed.), Voprosy iazyka sovremennoi russkoi literatury, Moscow: Nauka, 1971, pp. 9-96.

67 Levin, “'Neklassicheskie” tipy povestvovaniia', p. 248. 
68 Like Levin and Natal'ia Kozhevnikova, Belaia also stresses the use of the language of the people in $s k a z$ and the dominance of the character over objective authorial narration. She links this phenomenon to the revolution: 'Posle revoliutsii okazalos' nevozmozhno pisat' po-staromu; okazalos', chto narod iavliaetsia ne tol ko ob"ektom, no kak by i sub"ektom povestvovaniia.' Belaia, Zakonomernosti stilevogo razvitiia, p 10.

69 Natal'ia Kozhevnikova, 'O tipakh povestvovaniia v sovetskoi proze', in V. D. Levin (ed.), Voprosy iazyka sovremennoi russkoi literatury, Moscow: Nauka, 1971, pp. 97- 163 (p. 98).

70 Ibid., p. 99.

71 Ibid., p. 101.

72 Bakhtin, Problemy tvorchestva Dostoevskogo, p. 87. Bakhtin sees stylised skaz as the most common form, sometimes referring to it as simple skaz.

73 Stylisation may be likened to sympathetic pastiche.

74 Bakhtin, Problemy tvorchestva Dostoevskogo, p. 82.

75 Zsuzsa Hetényi, ““Chto moi glaza sobstvennoruchno videli...” Osobennosti skazovykh tekstov v “Konarmii” I. Babelia', Studia Slavica Academiae Scientarium Hungaricae, 38/1-2 (1993), 95-101.

76 Michael S. Gorham, 'Tongue-Tied Writers: The Rabsel kor Movement and the Voice of the "New Intelligentsia" in Early Soviet Russia', Russian Review, 55 (1996), $412-29$ (p. 425). I have assumed that Gorham here is using parody broadly in the sense of ridicule. It should be noted, however, that the word is now applied to textual practices Bakhtin would have termed 'stylisation'. Linda Hutcheon uses it in this sense. Linda Hutcheon, A Theory of Parody: The Teachings of TwentiethCentury Art Forms, New York: Methuen, 1985. See also Margaret A. Rose, Parody: Ancient, Modern and Post-Modern, Cambridge: Cambridge University Press, 1993. I have been using the term parody in the negative sense in which Bakhtin uses it, as burlesque.

77 Natal'ia Kozhevnikova, 'O tipakh povestvovaniia v sovetskoi proze’, p. 101.

78 Ibid., p. 101. She further develops this exploration of the relations between the author and narrator's evaluations in Natal'ia Kozhevnikova, Tipy povestvovaniia v russkoi literature XIX-XX vekov, Moscow: Institut russkogo iazyka, Rossiiskaia Akademiia Nauk, 1994, p. 7.

79 Nevertheless, the relation of parody and irony is complex and will be dealt with at greater length below, in this chapter.

80 Natal'ia Kozhevnikova, Tipy povestvovaniia v russkoi literature XIX-XX vekov, p. 7. 
81 Eikhenbaum, 'Leskov i sovremennaia proza', p. 230. He argues that the comic is produced when a work focuses our attention on expression rather than meaning. This is a refinement of 'Kak sdelana "Shinel" Gogolia', where such a shift of attention was seen as characteristic of Gogol"s comic skaz.

82 Vinogradov, 'Problema skaza v stilistike', p. 194.

83 There have been readings of Rudyi Pan ko's introduction that cogently argue it to be a sincere stylisation. See A. V. Samyshkina 'K probleme gogolevskogo fol 'klorizma (Dva tipa skaza i literaturnaia polemika v "Vecherakh na khutore bliz Dikan 'ki”)', Russkaia literatura, 22/3 (1979), 61-80. This article is discussed below (Chapter III) in relation to Gogol'.

84 Léna Szilárd, 'Skaz as a Form of Narration in Russian and Czech Literature', in Jean Bessière (ed.), Fiction, texte, narratologie, genre, New York: Peter Lang, 1989, pp. 181-90.

85 Ibid., p. 185.

86 Christopher English also refers to the 'double-focus' of skaz. He sees this as the contradiction between the illusion of oral delivery and the actually highly literary nature of the form. Christopher English, “'Schalk Lourens and Ivan Flyagin"', p. 160.

87 Szilárd, 'Skaz as a Form of Narration in Russian and Czech Literature', p. 185.

88 However, she takes no account of the fact that Zoshchenko was writing at a time of social and hence linguistic upheaval, for an audience who often saw his narrator's non-standard language as evidence of his trustworthiness rather than his untrustworthiness.

89 A. Bocharov, Literatura i vremia: iz tvorcheskogo opyta prozy 60-kh-80-kh godov, Moscow: Khudozhestvennaia literatura, 1988, p. 281.

90 J. A. K. Thomson, Irony: An Historical Introduction, London: Allen and Unwin, 1926, p. 163.

91 Examples abound of the definition of irony as targetting the meaning or coherence of the quoted point of view or opinion. Muecke, for example, argues that traditional irony is 'saying one thing and giving to understand the contrary'. D. C. Muecke, Irony and the Ironic, 2nd edn, rev., London: Methuen, 1982, p. 31. Similarly Ivan Volkov: 'V svoem prosteishem vide ironiia predstavliaet soboi odin iz sposobov inoskazaniia, kogda predmet ili kakoe-to ego svoistvo oboznachaetsia slovom ili slovami priamo protivopolozhnogo smysla s tsel'iu komicheskoi kharakteristiki deistvitel'nogo znacheniia predmeta.' Ivan Volkov, Teoriia literatury, p. 126. Boris Tomashevskii also sees irony like this: 'nasmeshlivoe upotreblenie slov v protivnom znachenii'. Boris. B. Tomashevskii, Stilistika 
i stikhoslozhnenie: kurs lektsii, Leningrad: Gosudarstvennoe uchebno-pedagogicheskoe izd. ministerstva prosveshcheniia RSFSR, 1959, p. 240.

92 Ernst Behler, Irony and the Discourse of Modernity, Seattle: University of Washington Press, 1990, p. 81 .

93 Wayne C. Booth, A Rhetoric of Irony, Chicago IL: The University of Chicago Press, 1974, pp. 7172.

94 Kierkegaard sees irony as a disparity between the essence and the phenomenon: 'the phenomenon is not the essence but the opposite of the essence. When I am speaking, the thought, the meaning, is the essence, and the word is the phenomenon.' Yet 'through a negation of the immediate phenomenon, the essence becomes identical with the phenomenon.' Søren Kierkegaard, The Concept of Irony with Continual Reference to Socrates, tr. H.V. and E. H. Hong, Princeton NJ, Princeton University Press, 1989, pp. 247-48.

95 Lilian R. Furst, The Contours of European Romanticism, London: Macmillan, 1975, p. 19.

96 Bakhtin, Problemy tvorchestva Dostoevskogo, p. 86.

97 Booth, A Rhetoric of Irony, p. 70.

98 The term irony in Greece originates with the eiron, the ironist or dissembler, a character in comedy who turns out to be far less of a fool than he appears. The character takes on an existence independent from the drama with the accusation that Socrates is an eiron in The Republic. Subsequently it becomes a rhetorical figure. Usage of the term expands greatly in the Romantic period. See Muecke, Irony and the Ironic; also see Thomson, Irony: An Historical Introduction.

99 Bakhtin, Problemy tvorchestva Dostoevskogo, p. 86.

100 This concept is defined in particular in his earlier work: Wayne C. Booth, The Rhetoric of Fiction, Chicago IL: University of Chicago Press, 1961, pp. 156-58.

101 W. K. Wimsatt and M. C. Beardsley, 'The Intentional Fallacy', in The Verbal Icon: Studies in the Meaning of Poetry, Kentucky: The University of Kentucky Press, 1954, pp. 3-30 (p. 3); repr. in David Newton de Molina (ed.), On Literary Intention, Edinburgh: Edinburgh University Press, 1976, pp. $1-13$ (p.1).

102 See Frank Cioffi's perceptive examination of the above mentioned article in Frank Cioffi, 'Intention and Interpretation', in de Molina (ed.), On Literary Intention, pp. 55- 73. 
103 'The Death of the Author', in Roland Barthes, Image, Music, Text, tr. Stephen Heath, London: Fontana, 1977, pp. 142-48.

104 This is not universally the case: David Shepherd is an example of a critic who permits or rather insists on reference to context, but who criticises reference to authorial intention as fostering ultimately oppressive myths of the artist's personality and genius. David Shepherd, Beyond Metafiction: Self-Consciousness in Soviet Literature, Oxford: Clarendon Press, 1992, pp. 191-203. 105 This example has been slightly adapted from Dan Sperber and Deirdre Wilson, 'Irony and the UseMention Distinction', in P. Cole (ed.), Syntax and Semantics 9: Pragmatics, New York: Academic Press, 1981, pp. 295-318; repr. Steven Davis (ed.), Pragmatics: A Reader, Oxford: Oxford University Press, 1991, pp. 550-63 (p. 553).

106 Karen L. Ryan-Hayes, Contemporary Russian Satire: A Genre Study, Cambridge: Cambridge University Press, 1995, p. 8.

107 Colin Lyas, Aesthetics, London: University College London Press, 1997, p. 145. Also see Colin Lyas, 'Wittgensteinian Intentions', in Gary Iseminger (ed.), Intention and Interpretation, Philadelphia PA: Temple University Press, 1992, pp. 132-51. This whole book provides articles from various perspectives in the debate.

108 Booth made this point in The Rhetoric of Fiction with an example drawn from Ring Lardner's Haircut, which is usually considered amongst the best Western examples of skaz: Booth, The Rhetoric of Fiction, pp. 6-7.

109 Lyas, Aesthetics, p. 154-55.

110 Ibid., p. 155.

111 Booth, A Rhetoric of Irony, p. 57.

112 Ibid., p. 125.

113 Ibid., p. 73. As we shall see, Zoshchenko presents particular problems here since he claims both that his narrator's manner of writing is the most appropriate to the epoch and that he is parodying the narrator.

114 For a discussion of the effects of Soviet censorship upon literary style, see Lev Loseff, On the Beneficence of Censorship: Aesopian Language in Modern Russian literature, Munich : Otto Sagner, 1984. 
115 Booth, A Rhetoric of Irony, p. 222. 'What sounds ironic to us may have been quite plainly meant' Thomson, Irony: an Historical Introduction, p.112. In Rabelais and his World, Bakhtin stresses the other alternative, that there is much more irony in the culture of the past than we suspect. Mikhail Bakhtin, Rabelais and His World, tr. Helene Iswolsky, Cambridge MA: MIT Press, 1968, p. 135.

116 Ong, Interfaces of the Word, p. 283.

117 Ibid., p. 291

118 Ibid., p. 289.

119 See Aristotle, Poetics, tr. with an introduction by Malcom Heath, Harmondsworth: Penguin, 1996, p. lxii. This aspect of the comic tradition is discussed at greater length below in Chapter V.

120 Hohne, 'Skaz and Babel"s "Konarmija"'.

121 Karen Ann Hohne, 'Dialects of Power: The Two Faced Narrative', in Cythia Goldin Bernstein (ed.), The Text and Beyond: Essays in Literary Linguistics, Tuscaloosa: University of Alabama Press, 1994, pp. 227-38 (p. 228).

122 Hohne, 'Skaz and Babel’s Konarmija', p. 26.

123 Ibid., p. 28.

124 Ibid., p. 34.

125 Kreps also assumes that the reader of skaz unites with the author against the narrator. Kreps, 'Mixail Zoščenko as Humorist and Satirist: A Structural Approach', p. 96.

126 Hohne, 'Skaz and Babel”s Konarmija', p. 39.

127 This is also called subjectivised prose. See Kveta Kozhevnikova, 'Sub”ektivizatsiia i ee otnoshenie k stiliu sovremennoi epicheskoi prozy’, Československá rusistika, $13 / 4$ (1968), 236-42.

128 The authors of Poetika skaza make this point well. Mushchenko et al., Poetika skaza, p. 42. 


\section{Chapter III: A History of Skaz}

1 See in particular Levin, “'Neklassicheskie” tipy povestvovaniia', passim; Titunik, 'The Problem of Skaz in Russian Literature', passim; and Natal'ia Kozhevnikova, 'O tipakh povestvovaniia v sovetskoi proze', passim.

2 This is not true of Mushchenko et al., Poetika skaza.

3 Hugh McLean seems to me such a critic. See Hugh McLean, Nikolai Leskov: The Man and his Art, Cambridge MA, Harvard University Press, 1977

4 Ekhenbaum, 'Leskov i sovremennaia proza', passim.

5 Levin, “'Neklassicheskie” tipy povestvovaniia', p. 245; Levin, 'Literaturnyi iazyk I khudozhestvennoe povestvovanie', in V. D. Levin (ed.), Voprosy iazyka sovremennoi russkoi literatury, Moscow: Nauka, 1971, pp. 9-96 (passim). Natal'ia Kozhevnikova, 'O tipakh povestvovaniia v sovetskoi proze', p. 99.

6 An example of the use of the concept of literaturnyi iazyk with regard to the spoken language is A. N. Gvozdev, Sovremennyi russkii literaturnyi iazyk: posobie dlia pedagogicheskikh institutov ( $v$ dvukh chastiakh), Moscow: Gosudarstvennoe uchebno-pedagogicheskoe izd. ministerstva prosveshcheniia RSFSR, 1963, passim. However, not all commentators use the term in this way. Some see the term as referring exclusively to the written language. See, for example, A. I. Sobolevskii, Istoriia russkogo literaturnogo iazyka, Leningrad: Nauka, 1980.

7 Levin, "Neklassicheskie" tipy povestvovaniia', p. 246.

8 Aleksandr Efimov, Stilistika khudozhestvennoi rechi, Moscow: Izd. Moskovskogo gosudarstvennogo universiteta, 1957, pp. 220-21. For suggestions that prostorechie is urban see S. I. Ozhegov, Slovar' russkogo iazka, 9th edn, rev. N. Iu. Shvedova, Moscow: Sovetskaia entsiklopediia, 1972, s.v. 'prostorechie'. Also see V. V. Vinogradov, Ocherki po istorii russkogo literaturnogo iazyka XVII-XIX vekov, 2nd edn, Leyden: E. I. Brill, 1949, pp. 421-43.

9 See ibid., passim.

10 An interesting example of the 1930s insistence on a normative conception of literaturnyi iazyk used to underpin a rigid conception of Realism can be found in Viktor Gofman, Iazyk literatury (ocherki I etiudy), Leningrad: Gosudarstvennoe izd. khudozhestvennoi literatury, 1936, pp. 130-36.

11 Christopher Nash, World -. Games: The Tradition of Anti-Realist Revolt, London: Methuen, 1987, p. 
12 Ibid., p. 11.

13 Most commentators accept that in fact there is no neutral language. For a discussion of this norm see Levin, “Neklassicheskie" tipy povestvovaniia' and Titunik, 'The Problem of Skaz in Russian Literature'.

14 J. P. Stern, On Realism, London: Routledge and Kegan Paul, 1973, p. 75.

15 As a result of their socially and often regionally marked language, skaz writers are consistently said to be untranslatable: e.g. Mirsky of Gogol' (p. 149) and of Leskov (p. 315). D. S. Mirsky, A History of Russian Literature, ed. and abridged by Francis J. Whitfield, London: Routledge and Kegan Paul, 1949.

16 Nash, World-Games, p. 9.

17 Philippe Hamon, 'On the Major Features of Realist Discourse', in Lilian R. Furst (ed.), Realism, London: Longman, 1992, pp. 166-85 (p. 170).

18 Ibid., p. 175.

19 Donald Fanger, 'Influence and Tradition in the Russian Novel', in John Garrard (ed.), The Russian Novel from Pushkin to Pasternak, New Haven CT: Yale University Press, 1983, pp. 29-49 (p. 29).

20 See for example Szilárd, 'Skaz as a form of Narration in Russian and Czech Literature’; Eikhenbaum, 'Leskov i sovremennaia proza'; Vinogradov, 'Problema skaza v stilistike'.

21 V. Deriagin, 'Predislovie', in Vladimir Dal' [Kazak Luganskii], Polnoe sobranie sochinenii v vos 'mi tomakh, Moscow: Stolitsa, 1995, I, pp. vi-xv (p. viii).

22 P. I. Mel'nikov, 'Vladimir Ivanovich Dal': kritiko-biograficheskii ocherk', in Vladimir Dal', Polnoe sobranie sochinenii v vos'mi tomakh, I, pp. xvi-lxxxii (p. xxii).

23 These can be found in Vladimir Dal', Izbrannye proizvedeniia, Moscow: Pravda, 1983 and Vladimir Dal’, Povesti i rasskazy, Moscow: Sovetskaia Rossiia, 1983.

24 Vladimir Dal', 'Poltora slova o nyneshnem russkom iazyke', Moskovitianin, I (1847), pp. 549-50. Quoted in P. I. Mel'nikov, 'Vladimir Ivanovich Dal': kritiko-biograficheskii ocherk', in Vladimir Dal', Polnoe sobranie sochinenii v vos'mi tomakh, I, pp. xvi-lxxxii (p. xxxvi).

25 Quoted in Charles A. Moser (ed.), The Cambridge History of Russian Literature, 2nd edn, rev. Cambridge: Cambridge University Press, 1992, p. 206. Gofman also sees Dal"s skaz as plotless: Viktor Gofman, 'Fol'klornyi skaz Dalia', in Boris Eikhenbaum and Iurii Tynianov (eds), Russkaia proza [1926]; repr. The Hague: Mouton, 1963, pp. 232-57 (p. 246). 
26 Nikolai Chernyshevskii, Polnoe sobranie sochinenii v piatnadtsati tomakh, ed. V. Ia. Kirpotin et al., Moscow: Gosudarstvennoe izd. khudozhestvennoi literatury, 1939-53, VII, p. 983-84.

27 See Gofman, Iazyk literatury, p. 130-36. There is bitter irony in this criticism from a former champion of Dal"s prose.

28 It should be noted that even Dal"s use of the common language may be seen as humorous. See for example, Joachim T. Baer, 'The Physiological Sketch', in To Honor Roman Jakobson: Essays on the Occasion of His Seventieth Birthday, The Hague: Mouton, 1967, pp. 1-12.

29 Nikolai Gogol', Polnoe sobranie sochinenii, ed. I. I. Lazarevskii, 14 vols, Moscow and Leningrad: Akademiia Nauk, 1937-52, I, p. 104. All references to Gogol’ are to this edition.

30 Ibid., I, p. 105.

31 Ibid., I, p. 107.

32 Ibid., I, p. 106.

33 What is parodic and what stylised in this cycle is far from a closed question. A. V. Samyshkina argues the contrary, that it is not Rudyi, but literary and Petersburg culture that is being ridiculed. A. V. Samyshkina, 'K probleme gogolevskogo fol'klorizma'. This critic discerns a highly complex interplay between stylised and parodic skaz. Though I do not find this argument convincing, I agree that both parodic and stylised skaz are at work in Gogol"s cycle.

34 Gogol', Polnoe sobranie sochinenii, I, pp. 137-38. According to Magarshack, this interjection was added by Gogol' after the editor of Otechestvennye zapiski had removed some of the colloquialisms and ukrainianisms. David Magarshack, Gogol: A Life, London: Faber and Faber, 1957, p. 63.

35 Samyshkina argues this: 'K probleme gogolevskogo fol klorizma', p. 68.

36 Examples of Gogol"s interest in folklore and ethnography can be found in his enthusiastic essay on Ukrainian folk songs in Arabeski and his notes in his scrapbooks compiled between 1826 and 1831. Referred to in Magarshack, Gogol: A Life, p. 39.

37 'Sorochinskaia iarmarka' is the one story in the cycle, where the supernatural is exposed as an illusion.

38 D. D. Blagoi (ed.), Istoriia russkoi literatury v trekh tomakh, Moscow and Leningrad: Izd. Akademii Nauk SSSR, 1963, p. 394.

39 Ibid., p. 395. Also see G. A. Gukovskii, Realizm Gogolia, Moscow and Leningrad: Gosudarstvennoe izd. khudozhestvennoi literatury, 1959, pp. 40-61. 
40 Viktor Vinogradov, Evoliutsiia russkogo naturalizma: Gogol ${ }^{\prime} i$ Dostoevskii, Leningrad: Academia, 1929, p. 2961

41 Nikolai Chernyshevskii, Polnoe sobranie sochinenii v piatnadtsati tomakh, VII, p. 858.

42 See, for example, Hohne, 'Skaz and Babel”s Konarmija'.

43 Robert A. Maguire, Exploring Gogol, Stanford CA: Stanford University Press, 1994, pp. 198-99.

44 See Nikolai Chernyshevskii, Polnoe sobranie sochinenii v piatnadtsati tomakh, III, p. 18.

45 Zakharov, Sistema zhanrov Dostoevskogo, pp. 42-56. See above, Chapter II

46 Quoted in A. I. Faresov, Protiv techenii, St Petersburg, 1904, p. 275, see also McLean, Nikolai Leskov: The Man and his Art, p. 153. Leonid Grossman also sees Leskov's skaz as a form of characterisation: 'slovesnaia kharakteristika personazha'. Leonid Grossman, Nikolai Leskov, Moscow: Ogiz, 1945, p. 281.

47 Letter to K. A. Grehwe, 5 December 1888. Manuscript department of Lenin library. Quoted in Valentina Gebel', N. S. Leskov: v tvorcheskoi laboratorii, Moscow: Sovetskii pisatel’’, 1945, p. 189.

48 McLean, Nikolai Leskov: The Man and his Art, p. 235.

49 N. S. Leskov, Sobranie sochinenii v odinnadtsati tomakh, ed. V. G. Bazanov, Moscow: Khudozhestvennaia literatura, 1956, I, p. 151.

50 McLean, Nikolai Leskov: The Man and his Art, p. 154.

51 Ibid., p. 154.

52 For example Boris Tomashevskii, Stilistika i stikhoslozhenie: kurs lektsii, p. 176.

53 Vestnik Evropy, 7 (July 1882). Quoted in Leskov, Sobranie sochinenii, VII, p. 503.

54 This was later removed. It appears in Leskov, Sobranie sochinenii, VII, p. 394. McLean incorporates a translation in his book. McLean, Nikolai Leskov: The Man and his Art, p. 394. Fed' sees Leskov's narrator, Leskov, and the people as indivisible: Nikolai Fed', Paradoks $o$ polozhitel'nom geroe, Moscow: Sovremennik, 1986, p. 314.

55 McLean, Nikolai Leskov: The Man and his Art, p. 399.

56 Aleksej B. Ansberg also sees Leskov's use of skaz as motivated by the need to avoid censorship: Aleksej B. Ansberg, 'Frame Story and First Person Story in N. S. Leskov', Scando - Slavica, 3 (1957), $49-73$ (p. 52).

57 McLean, Nikolai Leskov: The Man and his Art, p. 608.

58 Ibid., p. 231. 
59 According to McFarlane and Bradbury Modernism assumes 'a notion of the relationship of crisis between art and history'. Malcom Bradbury and James McFarlane 'The Name and Nature of Modernism', in Malcom Bradbury and James McFarlane (eds), Modernism 1890-1930, 2nd edn, rev., Harmondsworth: Penguin, 1991, pp. 19-55 (p. 29).

60 Irina Paperno, 'Introduction', in Irina Paperno and Joan Delaney Grossman (eds), Creating Life: The Aesthetic Utopia of Russian Modernism, Stanford CA: Stanford University Press, 1994, pp. 1-11 (p. 3).

61 Gabriel Josipovici, 'The Lessons of Modernism', in Gabriel Josipovici, The Lessons of Modernism and Other Essays, 2nd edn, Basingstoke: Macmillan, 1997, pp. 109-23 (p. 109).

62 Natal'ia Kozhevnikova, Tipy povestvovaniia v russkoi literature XIX-XX vekov, p. 75.

63 Aleksandr Chudakov, Chekhov's Poetics, tr. Edwina Jannie Cruise and Donald Dragt, Ann Arbor MI: Ardis, 1983, p. 62.

64 Stern, On Realism, p. 141.

65 Booth sees an ironically ambiguous authorial position as a characteristic of modern literature: Booth, A Rhetoric of Fiction, p. 323. Grossman stresses the widespread use of parody in the period immediately after 1905. Leonid Grossman, 'Parodiia kak zhanr literaturnoi kritiki', in Boris Begak et al. (eds), Russkaia literaturnaia parodiia, Moscow: Gosizdat, 1930; repr. Ann Arbor MI: Ardis, 1980, pp. 39-48 (p. 44).

66 Léna Szilárd, 'Ornamental'nost'/ Ornamentalizm', Russian Literature, 19 (1986), $65-78$ (p. 65).

67 Patricia Carden, 'Ornamentalism and Modernism', in George Gibian and H. W. Tjalsma (eds), Russian Modernism: Culture and the Avant-garde 1900-1930, Ithaca NY, Cornell University Press, 1976, pp. 49-64 (p. 49). See above (Chapter II) and also see later in this chapter for the distinction between ornamentalism and skaz.

68 Z. G. Mints, 'Russkii simvolizm i revoliutsiia 1905-1907 godov', Uchenye zapiski Tartuskogo gosudarstvennogo universiteta, 813 (1988), pp. 3-21 (p.9).

69 Andrei Belyi, Sobranie sochinenii: Serebrianyi golub', rasskazy, ed. V. M. Piskunov, Moscow: Respublika, 1995, p. 17.

70 Quoted in Natal'ia Kodrianskaia, Aleksei Remizov, Paris: Natalie Codray, 1959, p. 130.

71 This has led certain critics to see Remizov's prose style as ornamental skaz. Levin argues that it is not skaz at all, since it is not linked to a character, but a new and revolutionary form of narration: 
Levin “"Neklassicheskie” tipy povestvovaniia'. Szilárd sees it as ornamentalism. Szilárd,

'Ornamental'nost' / Ornamentalizm'.

72 Charlotte Rosenthal, 'Primitivism in Remizov's Early Short Works (1900-1903)', in Greta N. Slobin (ed.), Aleksej Remizov: Approaches to a Protean Writer, Colombus OH: Slavica, 1987, pp. 195-205 (p. 203).

73 Greta N. Slobin, Remizov's Fictions 1900-1921, DeKalb: Northern Illinois University Press, 1991, p. 119.

74 Aleksei Remizov, Sobranie sochinenii, ed. Dmitii Chizhevskii et al., 4 vols, St Petersburg: Shipovnik, 1911; repr. Munich: Wilhelm Fink, 1971, IV, pp. 13-157 (p. 19).

75 It can be argued that Remizov was himself a Neo-Realist, as Alex Shane has done. Certainly he was not a mainstream Symbolist. Alex M. Shane, 'Remizov's Prud: From Symbolism to Neo-Realism', California Slavic Studies, 6 (1971), 71-82.

76 Evgenii Zamiatin, 'O sintetizme', in Izbrannye proizvedeniia, ed. with an introduction and notes by E. B. Skorospelova, Moscow: Sovetskaia Rossiia, 1990, pp. 410-17.

77 Zamiatin, Sochineniia, ed. Evgeniia Zhiglevich with an introduction by Aleksandr Kashin, 4 vols, Munich: A. Neimanis, 1970, I, p. 51.

78 Ibid., I, pp. $72-73$.

79 Alex M. Shane, The Life and Works of Evgenij Zamjatin, Berkeley: University of California Press, 1968, p. 122. Philip Cavendish stresses this point. See Philip John Cavendish, 'Evgenii Zamiatin and the Literary Stilization of Rus”, unpublished doctoral thesis, University of London, 1997.

80 For example, 'Rasskaz o samom glavnom', in Evgenii Zamiatin, Izbrannye proizvedeniia, pp. 189215; and 'O literature, revoliutsii, entropii i o prochem', ibid., pp. 431-36.

81 In Natal'ia Kozhevnikova, Tipy povestvovaniia v russkoi literature XIX-XX vekov. Kozhevnikova sees the difference between skaz and ornamentalism in the different purposes for which the writer selects it: skaz for a socially other point of view, usually that of a character; ornamentalism, simply for the style. The latter never has a character narrator, since that would be an unacceptable restriction upon the form's stylistic freedom. Kozhevnikova sees Zamiatin and Belyi as a combination of both ornamentalism and skaz, and Babel’’ and Zoshchenko as properly skaz.

82 A. Lezhnev, Sovremenniki: literaturno-kriticheskie ocherki, Moscow: Krug, 1927, p. 65. Quoted in Rybakov, p.84. 
83 Rybakov, 'K probleme skaza v khudozhestvennoi literature’, p. 84.

84 Natal'ia Kozhevnikova, 'O tipakh povestvovaniia v sovetskoi proze', p. 102.

85 Galina Belaia, 'Problema aktivnosti stilia: $\mathbf{k}$ issledovaniiu istoricheskoi produktivnosti stilei 20-kh godov', in S. Bocharov et al. (eds), Smena literaturnykh stilei, Moscow: Nauka, 1974, pp. 122-77. 86 Ibid., p. 125.

87 Ibid., p. 130. The other examples Belaia gives of this are the stories of Zoshchenko, and Leonov's Zapiski Koviakina, which she terms 'stilizovannyi skaz'.

88 'Every successful revolution shakes authority and makes social cohesion more difficult.' Bertrand Russell, Power: A New Social Analysis, London: Allen and Unwin, 1963, p. 75.

89 A. V. Lunacharskii, Sobranie sochinenii v vos'smi tomakh, ed. I. I. Anisimov et al., Moscow, 196367, I, pp. 357-58. Quoted in Belaia, Zakonomernosti stilevogo razvitiia, p. 47.

90 Ong too argues that the novel is the apogee of written and print culture, and argues that it dealt a final blow to oral narration and orality as a whole. Ong, Orality and Literacy, pp. 139-55.

91 Eikhenbaum, 'Leskov i sovremennaia proza', p. 218.

92 Ibid., p. 238.

93 For example, Szilárd, 'Skaz as a Form of Narration in Russian and Czech Literature', p. 187, and Vinogradov, 'Problema skaza v stilistike’, p. 202.

94 Ong, Interfaces of the Word, p. 60.

95 Victor Erlich, Modernism and Revolution: Russian Literature in Transition, Cambridge MA: Harvard University Press, 1994, p. 11. 


\section{Chapter IV: The Evolution of Zoshchenko's Art: Early Work}

1 Vera Zoshchenko, 'Tak nachinal M. Zoshchenko', in Vospominaniia o Mikhaile Zoshchenko, pp. 528 (p. 6-7). 'Dvugrivennyi' was rewritten as 'Iskushenie' (1922), in Mikhail Zoshchenko, Uvazhaemye grazhdane: parodii, rasskazy, fel'etony, satiricheskie zametki. Pis'ma k pisateliu, odnoaktnye komedii, ed. Mikhail Dolinskii, Moscow: Knizhnaia palata, 1991, p. 160. References to this collection will hereafter be given in the body of the text, as Uvazhaemye grazhdane.

2 Vera Zoshchenko, the writer's wife, comments that Zoshchenko was constantly using his letters to her and others as literary exercises. These were often written in the style of writers that he admired at the time such as Nietzsche and Artsybashev: 'eto ne pis'ma kak takovye, a tozhe literaturnye proizvedeniia'. Vera Zoshchenko, 'Tak nachinal M. Zoshchenko', in Vospominaniia o Mikhaile Zoshchenko, p. 12.

3 See Chukovskii, 'Iz vospominanii', p. 39.

4 See 'O Vladimire Maiakovskom', and 'Vl. Maiakovskii: poet bezvremen ia u Maiakovskogo', in Mikhail and Vera Zoshchenko, Neizdannyi Zoshchenko, ed. Vera von Wiren, Ann Arbor MI: Ardis, n.d., pp. 57-61 and pp. 62-64. Also see A. I. Pavlovskii (ed.), 'Stat'ia M. M. Zoshchenko o B. K. Zaitseve', in N. A. Groznova (ed.), Mikhail Zoshchenko: materialy k tvorcheskoi biografii (kniga pervaia), St Petersburg: Nauka, 1997, pp. 37-48.

5 Chudakova, Poetika Mikhaila Zoshchenko, pp. 23-24.

6 Hongor Oulanoff argues that Zoshchenko was typical of the Serapions, and analyses Sinebriukhov as typical of Zoshchenko. I disagree on both counts. As we shall see, these stories were in fact not altogether typical of his work. Hongor Oulanoff, The Serapion Brothers: Theory and Practice, The Hague: Mouton, 1966. See also Gary Kern and Christopher Collins (eds), The Serapion Brothers: A Critical Anthology, Ann Arbor MI: Ardis, 1975.

7 Serapionovy brat 'ia: al'manakh pervyi, St. Petersburg: Alkonost, 1922, pp. 7-19.

8 Starkov has called this period of Zoshchenko's work (1921-22) a period of search for a new form capable of expressing an already understood content. Starkov, Mikhail Zoshchenko: sud'ba khudozhnika, p. 26.

9 Dates refer to the date of publication, unless stated otherwise. Dates of composition often differ significantly in this early period of Zoshchenko's work, and are referred to in the text where relevant. Sinebriukhov was published in December 1921, but dated 1922. 
10 'Khronologicheskaia kanva zhizni i tvorchestva Mikhaila Zoshchenko', in Iurii Tomashevskii (ed.), Litso i maska Mikhaila Zoshchenko, Moscow: Olimp, 1994, pp. 340-64.

11 Mikhail Zoshchenko, Sobranie sochinenii $v$ trekh tomakh, ed. with an introduction and notes by Iurii Tomashevskii, Leningrad: Khudozhestvennaia literatura, 1986, I, pp. 538-39. Referred to hereafter in the text as $S S$. The volume number will be given as an upper-case roman numeral.

12 Zoshchenko uses skaz for a similar purpose in 'Poslednii barin', (1922), in Uvazhaemye grazhdane, pp. 168-76.

13 Chudakova, Poetika Mikhaila Zoshchenko. Other examples are Starkov, Mikhail Zoshchenko: sud'ba khudozhnika; Moldavskii, Mikhail Zoshchenko: ocherk tvorchestva.

14 Starkov, Mikhail Zoshchenko: sud ba khudozhnika, p. 32. Starkov sees the importance of Sinebriukhov in its use of personalised skaz, which he calls a 'sredstvo avtokharakteristiki geroiia'. It is certainly true that the narrative serves to characterise the narrator in these stories, but it also serves to make a more direct appeal to the reader's sensibilities than was possible with the impersonalised forms of skaz that Zoshchenko experimented with in other works of this period.

15 'Avtobiografiia Zoshchenko Mikhaila Mikhailovicha', [1932], first published in Uvazhaemye grazhdane, pp. 591-93 (pp. 591-92).

16 Iurii Tomashevskii, 'Primechaniia', in SS I, pp. 538-39. We shall return to the question of how successful he was in 'restructuring habitual literary language' later.

17 See also 'Kak ia rabotaiu', Literaturnaia ucheba, 3 (1930), 107-14; repr. Uvazhaemye grazhdane, pp. 586-90. Also see ‘Avtobiografiia’ [1932], Uvazhaemye grazhdane, pp. 591-93.

18 There are stories where a neutral, impersonal narrator gives a one or two line introduction to a narrator-participant skaz story. An example of this is one variant of 'Aristokratka': 'Grigorii Ivanovich shumno vzdokhnul, vyter podborodok rukavom i nachal rasskazyvat': - Ia, bratsy moi'. This variant can be found, for example, in Mikhail Zoshchenko, Izbrannye proizvedeniia $v$ dvukh tomakh, Leningrad: Khudozhestvennaia literatura, 1968, I, pp. 86-89. I classify such stories as skaz, since the neutral narration is only a brief frame.

20 This narrative device is described and defined at length in Katowitz, 'A Study of the Character and Function of the Narrator-Participant'. Katowitz uses the term only where the narrator is 'the chief influence on the movement of the plot', p. 5. I use it more loosely for any story where the narrator is a discernible character in his own story. Despite elaborating helpful terminology, Katowitz follows 
the major trend in the analysis of skaz and assumes all of it to be parodic: 'Since this narrator is fully characterised, his commentary is immediately discredited', p. 17. As I have attempted to show in my analysis of skaz and shall attempt to show in my analysis of Zoshchenko, this need not necessarily be the case. 


\section{Chapter V: Zoshchenko's Skaz and Journalism}

1 For a description of the characteristics of this new journalistic culture, see Jeffrey Brooks, 'Public and Private Values in the Soviet Press, 1921-1928', Slavic Review , 48/1 (Spring 1989), 16-35 (p. 16). Brooks has also conducted the definitive analysis of the popular culture that it supplanted: Jeffrey Brooks, When Russia Learned to Read: Literacy and Popular Culture, 1861-1917, Princeton NJ: Princeton University Press, 1985.

2 It is a commonplace to say that literature was inseparable from or at least closer to life in the immediate post-revolutionary period. See E. B. Skorospelova, Ideino-stilevye techeniia v russkoi sovetskoi proze pervoi poloviny 20-kh godov, Moscow: Izd. Moskovskogo gosudarstvennogo universiteta, 1979, p. 8. See aiso V. P. Skobelev, Massa i lichnost' v russkoi sovetskoi proze 20-kh godov (K probleme narodnogo kharaktera), Voronezh: Izd. Voronezhskogo gosudarstvennogo universiteta, 1975, p. 21. Maguire summarises this tendency well: 'At a time when the claims of life seemed so urgent and exciting, the notebook, the diary, the travel memoir, and interpretive journalism became respected genres wherein art and life seemed most ready to intermingle.' Robert Maguire, Red Virgin Soil: Soviet Literature in the 1920s, Princeton NJ: Princeton University Press, 1968, p. 69.

3 He was also the most famous Soviet writer of the period outright, a fact stated by almost every commentator. In his introduction to the 1986 collected works Iurii Tomashevskii describes the star status Zoshchenko enjoyed: he was literally pursued by the public. SS I, p. 5 .

4 The 'thin' journal is a lowbiow popular magazine. Highbrow literature has traditionally been published in 'thick' journals such as Sovremennik and Krasnaia nov'. Mukhomor was a Petrograd satirical journal that was published between 1922 and 1923.

5 The criticisms intensified in 1927, with M. Ol'shevets's article in Izvestiia. This is reprinted in Iurii Tomashevskii (ed.), Litso i maska Mikhaila Zoshchenko, pp. 148-52. Tomashevskii has noted that this defensive tone continued until the work written after the 1934 1st Congress of Soviet writers, when criticism of his work became more muted, and his own articles became less defensive and more tended to argue a broader case. See Iurii Tomashevskii, "'Literatura dolzhna byt' narodnoi": iz tvorcheskogo naslediia M. M. Zoshchenko', Literaturnoe obozrenie, 9 (1984), 100-08. This article includes the text of a number of Zoshchenko's articles. Also see Iurii Tomashevskii, “'Ia vzial 
podriad na etot zakaz...": M. M. Zoshchenko o literature i ee iazyke', Russkaia rech', 5 (1987), 55-

64.

6 V. Veshnev typifies this accusation:

Разговорная речь у Зощенко самодовлеет, и именно на нее, главным образом, он тратит свою изобретательность (...) Тем не менсе искусственность остается и его разоблачает.

Она разоблачает тенденциозность подбора героев и тем. Его комическая речь не вытекает из характера героев и тем, а, наоборот, өти последние подбираются к приемам его языкового сочинительства (...) Все вто тщательно подбирается для смеха, ради смеха.

Iurii Tomashevskii (ed.), Litso i maska Mikhaila Zoshchenko, pp. 152-57 (p. 155).

7 In Iurii Tynianov and B. Kaganskii (eds), Mikhail Zoshchenko: Stat i i materialy, Leningrad: Academia, 1928, pp. 7-11; repr. Ann Arbor MI: Ardis, n. d.; also reprinted in Uvazhaemye grazhdane, pp. 584-86. All references are to this latter reprint.

8 Literaturnaia ucheba, 3 (1930), 107-114; repr. Uzazhaemye grazhdane, pp. 586-90. All references are to the reprint.

9 Mikhail Zoshchenko, Pis'ma k pisateliu, Leningrad: IPL, 1929; repr. Uvazhaemye grazhdane, pp. $345-430$ (p. 371).

10 An example of this view can be found in Vladimir Maiakovskii and Osip Brik 'Nasha slovesnaia rabota', Lef, 11 (1923), 40-41. Another example of this attitude to art is the mass spectacle in which there is no divide between the actors and the audience, indeed certain theoreticians of the time, e.g. Kerzhentsev of the Proletkul't, argued that any such divide was harmful. See Robert Russell, Russian Drama of the Revolutionary Period, Basingstoke: Macmillan, 1988, pp. 28-31.

11 Chuzhak argues that Lef did not think up literatura fakta but formulated something that the age demanded. Nikolai Chuzhak, 'Pisatel'skaia pamiatka', in Nikolai Chuzhak (ed.), Literatura fakta, Moscow: Federatsiia, 1929; repr. Munich: Wilhelm Fink, 1972, pp. 9-28 (p. 11).

12 The tension in Vertov's work between the shot and its interpretation through editing is analogous to the tension between the documentary fact and interpretation of it in Zoshchenko's work. For a general discussion of Vertov as a cine-journalist, and an exploration of this tension in his work see Erik Barnouw, Documentary: A History of the Non-Fiction Film, 2nd edn, rev., Oxford: Oxford University Press, 1993, p. 58.

13 S. Tret'iakov, 'Novyi Lev Tolstoi', in Chuzhak (ed.), Literatura fakta, pp. 29-33. 
14 For example his 1923 Sentimental 'noe puteshestvie. This was cited by Chuzhak as a model.

15 Carleton has initiated this work. However, he argues that the presence in one text of documentary and parodic elements undermines all referential potential in language and renders the given text meaningless. This seems an unconvincing account of the interaction between the documentary and parodic principles in Zoshchenko's short stories and feuilletons. Carleton, 'Problems of Text and Reception: Mixail Zoščenko'. See the discussion of Carleton's views above, Chapter I.

16 In his memoirs, Chukovskii stresses Zoshchenko's use of these letters in the 1920s: 'Materialy dia svoikh fel’etonov Zoshchenko cherpal iz mnozhestva pisem, prisylaemykh v redaktsiiu na imia Gavrilycha s raznykh kontsov gosudarstva.' Chukovskii, 'Iz vospominanii', p. 67.

17 A rabkor was a worker correspondent. See later for a more detailed explanation of the term.

18 Letter to Gor kii, 30 September, 1930, Gor kii i sovetskie pisateli: neizdannaia perepiska, p. 162.

19 Mikhail Zoshchenko, Passkazy, povesti, fel'etony, teatr, kritika, 1935-37, Leningrad:

Khudozhestvennaia literatura, 1937, pp. 374-80. Hereafter 1935-37.

20 This lack of distinction is something referred to by a number of commentators: See Leonid Ershov, Satiricheskie zhanry russkoi sovetskoi literatury (ot epigrama do romana), Leningrad: Nauka, 1977, p. 120; Ershov, Iz istorii sovetskoi satiry, p. 51. Also see Richard L. Chapple, Soviet Satire of the Twenties, Gainsville: The University of Florida, 1980, p. 13.

21 Iurii Tomashevskii reprinced preface from the feuilleton section of the second volume of Mikhail Zoshchenko, Sobranie sochinenii, 1929-32. There are very few surviving copies of this volume and I have been unable to track one down.

22 See for example 'Pis'ma v redaktiiu', which I discuss in the fourth section of this chapter.

23 Leonid Ershov, Satiricheskie zhanry russkoi sovetskoi literatury, pp. 95-163.

24 Ibid., p. 163.

25 [no author], Zhanry sovetskoi gazety, Moscow: Vysshaia shkola, 1972, p. 370.

26 The manner of this commentary also changes. In early copies of Krasnyi voron the columnist is represented as a red raven that 'pecks' those who have offended the letter writers by ridiculing them in a short poem. Later this changes into prose. However, particularly later in Begemot, the attitude changes and the columnist often laughs not with the letter writer against a common foe, but at the letter writer. The magazine evolved from useful political satire to satire on useful political satire for a more ambiguous ironic effect. 
27 Zhanry sovetskoi gazety, p. 370.

28 Jeffrey Brooks, 'The Press and its Message: Images of America in the 1920s and 1930s', in Sheila Fitzpatrick et al. (eds), Russia in the Era of NEP: Explorations in Soviet Society and Culture, Bloomington: Indiana University Press, 1991, pp. 231-52.

29 Leading article in Rabochii, 1 March, 1922, repr. in [no author], $O$ partiinoi i sovetskoi pechati: sbornik dokumentov, Moscow: Pravda, 1954, pp. 245-46.

30 Brooks, 'The Press and its Message: Images of America in the 1920s and 1930s', p. 231.

31 The organised way in which they wrote was one of their most distinctive characteristics. See Peter Kenez, The Birth of the Propaganda State: Soviet Methods of Mass Mobilization 1917-1929, Cambridge: Cambridge University Press, 1985, p. 233. Though, of course, during the 1920 s the spectrum of their permitted opinion shrank. Also see Bol'shaia sovetskaia entsiklopediia, Moscow: Ogiz (Sovetskaia entsiklopediia), 1926-31, s.v. 'rabkor'. This description is written in accordance with the prescriptions of Socialist Realism and also strikes a terrifying note: the worker correspondent was to unmask enemies of the people. In other words these letters were the embryonic literary form of the informer. Also see [no author], SSSR v period vosstanovleniia narodnogo khoziaistva (1921-1925 gody): istoricheskie ocherki, Moscow: Politicheskaia literatura, 1955, p. 541.

32 The numbers of rabsel kors rose prodigiously in this period. In 1924 there were 100000 . This had risen to 216000 by 1925. [no author], Partiinaia i sovetskaia pechat $v$ bor'be za postroenie sotsializma i kommunizma: uchebnoe posobie, 2nd edn, rev., Moscow: Mys', 1966, p. 79.

33 'Iashchik dlia zhalob', Krasnyi voron, 1 (1923). Begemot intensified this activity before ultimately moving towards less tendentious portrayals of everyday life in the USSR. For a detailed but onesided description of these changes, see S. Stykalin and I. Kremenskaia, Sovetskaia satiricheskaia pechat' 1917-1963, Moscow: Politlit, 1963.

34 Krasnyi voron was initially a supplement to Krasnaia gazeta. It became a separate publication, but was still published by Krasnaia gazeta.

35 Brooks, 'Public and Private Values in the Soviet Press, 1921-1928', p. 21.

36 Similarly, Vladimir Brovkin shows how the upper echelons of the party were informed through GPU reports of strikes, of the catastrophic state of enterprises etc.: "What they read qualified in the 
public sphere as malicious counter-revolutionary vilification of socialism.' Vladimir Brovkin, Russia After Lenin: Politics, Culture and Society, 1921-1929, London: Routledge, 1998, p. 60.

37 Brooks, 'Public and Private Values in the Soviet Press, 1921-1928', p. 25.

38 Maksim Gor 'kii, 'Eshche rabsel'koram', Sobranie sochinenii v tridtsati tomakh, Moscow: Khudozhestvennaia literatura, 1949-55, XXIV, p. 313.

39 Fedor Fedorovich Raskol'nikov [II' in], 'Rabkory i proletarskaia literatura', Na postu, 1 (6) (June 1925), 105-12; repr. Munich: Wilhelm Fink, 1971, pp. $105-12$ (p. 109).

40 In Boym's terms, Zoshchenko's stories were all written by graphomaniacs: would-be writers caught up in the trviality of the everyday. Svetlana Boym, Common Places: Mythologies of Everyday Life in Russia, Cambridge MA: Harvard University Press, 1994, p. 193.

41 Brooks, 'Public and Private Values in the Soviet Press, 1921-1928', p. 23.

42 Ibid., p. 22.

43 Boym defines byt as, 'everyday routine and stagnation' and bytie as 'spiritual being'. She also provides a history of the term. Boym, Common Places, p. 29.

44 See Sheila Fitzpatrick, 'The Problem of Class Identity in NEP Society', in Fitzpatrick et al. (eds), Russia in the Era of NEP. pp. 12-33.

45 For a discussion of the Russian working class's drinking habits in this period see Laura L. Philips, 'Message in a Bottle: Working Class Culture and the Struggle for Revolutionary Legitimacy, 19001929’, Russian Review, 56/1 (Jan 1997), 25-43.

46 Ibid., p. 37.

47 Ibid., pp. 34-35.

48 Ibid., p. 37.

49 Chukovskii, 'Iz vospominanii', p. 68.

50 This tradition dates as far back as Aristotle, whose Poetics originally contained a chapter on comedy which started from the premise, 'Comedy (...) is the imitation of inferior people.' Aristotle, Poetics, p. lxii. Lowly status and base behaviour were associated. Despite the revolution, art seems to have been unable to free itself from these hierarchical associations.

51 Gorham explores the unintendæd comic effects of the rabkors' letters. Gorham, 'Tongue-Tied Writers'.

52 This was pointed out to me by a former columnist at the teenage magazine, It's Bliss. 
53 Iurii Tomashevskii describes Zoshchenko's wide-ranging journalistic activities on the satirical press:

Зощенко писал громадное количество самой разнообразной жмелочиж. Просматривая сегодня вти (да и другие) сатирические журналы, заглядыгвая в [них] (...) то и дело натыкаешься на его следы: несколько строк, а спутать нельзя - өто он, Зощенко. Реклама подписки на «Бегемота», на «Пушку» - его почерк. Открытое письмо рабочих - его руха. Редакционный ответ селькору - его словечки. А сколько писем читателей им обработано, сколько подписей $\mathrm{x}$ карикатурам сочинено, схолько заголовков придумано!

Попробуй отыщи это все...

Iurii Tomashevskii, 'Zoshchenko - zhurnalist', Voprosy literatury, 7 (1984) , 253-68 (p. 253).

54 Raskol'nikov, 'Rabkory i proletarskaia literatura', p. 111.

55 Ershov, Satiricheskie zhanry russkoi sovetskoi literatury, p. 159; Ershov, Sovetskaia satiricheskaia proza, p. 137.

56 Ershov, Satiricheskie zhanry russkoi sovetskoi literatury, p. 149.

57 In particular, the first published versions of the stories in the satirical press follow the example of feuilletons by reacting to the issue of the day. Some of the contemporaneity of the references were filtered out in subsequent republications.

58 Ershov criticises Olesha's verse feuilletons in Gudok for failing to relate the isolated incident to the general theme. Ershov, Satiricheskie zhanry russkoi sovetskoi literatury, p. 135.

59 See for example Zhanry sovetskoi gazety, pp. 353-70. Ershov, Satiricheskie zhanry russkoi sovetskoi literatury, p. 148.

60 Ibid., p. 146.

61 Starkov has commented that the unsuccessful generalisations made by Zoshchenko's narrators resemble this feature of the feuilleton. See Starkov, Iumor Zoshchenko, pp. 57-58.

62 As we have seen, Zoshchenko claimed that these and all his feuilletons are genuine: 'Ot avtora', SS I, p. 448.

63 Popkin sees the theme of having one's foot stepped on as particularly significant in Zoshchenko: Cathy Popkin, "'Ne govoria uzhe o nogakh": "Nizhnie konehnosti“" v slovare Zoshchenko’, Literaturnoe obozrenie, 1 (248) (1991), p. 28.

64 I have concentrated my search on Krasnyi voron/Begemot and Drezina. 
65 Begemot, 10 (March 1925). I shall be referring to this original version of the story. It differs slightly from the version in the 1986 collected works (SS I, pp. 278-79), which uses the version from Uvazhaemye grazhdane, 1926. The main difference is the omission of the final sentence. I consider the original magazine published variants to be as good as and sometimes better than the variants selected by Iurii Tomashevskii for the 1986 collected works. See my discussion of Zoshchenko's later revisions of his work later in this chapter.

66 Begemot, 10 (March 1925).

67 For example, Zoshchenko refers to 'Bania' as a story in 'Kak ia rabotaiu', Uvazhaemye grazhdane, p. 588.

68 Mikhail Dolinskii notes that Zoshchenko 'odin i tot zhe tekst chislil v raznye gody to fel'etonom, to rasskazom'. Dolinskii ,'Golosa iz proshlogo', in Uvazhaemye grazhdane, pp. 5-30 (p. 11).

Accordingly he makes no distinction between the two genres in that edition of Zoshchenko's work. Editions of II'f and Petrov's work encounter the same difficulties.

69 Krasnyi voron, 11 (March 1923).

70 In the early 1920s in the USSR, America was the symbol for modernity and was used to promote any innovation. See Brooks, 'The Press and its Message', p. 239.

71 Although, as we shall see, if the narrator discounts the value of his personal experience, then the generalisation holds true, and the story is not ironic.

72 Gorham, 'Tongue-Tied Writers', p. 428.

73 Krasnyi voron, 18 (1924). In this period what had been 'Iashchik dlia zhalob' briefly appeared without a title before the magazine changed its name to Begemot, and adopted a new form for the same sort of column: 'Na prieme u Begemota'. It is possible that Zoshchenko, as a columnist on the magazine wrote the response in the reader's column. If he did write any of the items that I discuss here, I do not consider that this would devalue what I am doing, since I am stressing the continuity between Zoshchenko and the satirical press. Zoshchenko's best short stories are developed from this basis.

74 It should be noted that Russian uses a separate verbal root for washing clothes, "stirat" and for washing oneself, 'myt'sia'. When the narrator claims that you can wash in a Soviet bathhouse he is definitely not referring to the fact that people wash their clothes, even though he does describe those washing their clothes with the verb "myt". This is one of the story's substandard usages. 
75 Ershov, Satiricheskie zhanry russkoi sovetskoi literatury, p. 149.

76 Starkov, Iumor Zoshchenko, pp. 57-61: also see Starkov, Mikhail Zoshchenko: sud'ba khudozhnika, pp. 62-65.

77 Begemot, 8 (1925).

78 The narrator confesses his guilt in the magazine published version of the story: Smekhach, 1 (1924). In the version that appears in the 1986 collected works (SS I, pp. 181-82), the narrator runs away as the dog turns towards him, implying rather than confessing his guilt.

79 Drezina , 3 (1923).

80 Drezina, 12 (1923).

81 Begemot, 23 (1926).

82 Krasnyi voron, 15 (April 1924). The latter story appeared in Buzoter less than a year later. This would suggest that the narrator's confession in the original version of 'Sobachii niukh': 'beru v zhurnalakh advansy, dvazhdy pechataiu odin i tot zhe rasskaz'. (Smekhach, 1 (1924)), is actually true of Zoshchenko.

83 See above, earlier in this chapter.

84 From Chukovskii's diary, 26 March 1929. Quoted in Uvazhaemye grazhdane, p. 54.

85 Sarnov has examined some of the changes to the language in various editions of Zoshchenko's work. He puts the overwhelming case for disregarding the normal textological principle of seeing the last version published in the author's lifetime as canonical: Benedikt Sarnov, "Razvivaia traditsiiu Prokrusta" (Mikahil Zoshchenko i ego redaktory)', Voprosy literatury, 2 (1994), 45-91.

86 Begemot, 4 (1925).

87 Drezina, 9 (1923). 


\section{Chapter VI: Zoshchenko's Skaz Narration}

${ }^{1}$ For an in-depth analysis of Zoshchenko's vocabulary see Von Wiren-Garczynski, 'The Russian Language in the Immediate Post-Revolutionary period'. See also Viktor Vinogradov, 'Iazyk Zoshchenki (zametki o leksike)', in Tynianov and Kaganskii (eds), Mikhail Zoshchenko: stat ' $i$ i materialy, pp. 51-92. For an encyclopaedic account of the comic in Zoshchenko's language see Kreps, Tekhnika komicheskogo u Zoshchenko, pp. 29-106.

2 Many accounts of the comic or the ludicrous define it as the incongruous. Schopenhauer is the most disguished example of such theorists. Arthur Schopenhauer, Die Welt als Wille und Vorstellung, Stuttgart: Cotta-Insel, 1960, I, §13, pp. 104-08 and II, pp. 121-35. Also see Vladimir Propp, Problemy komizma i smekha, 2nd edn, St Petersburg: Aleteiia, 1997; Also see Kreps, Tekhnika komicheskogo u Zoshchenko.

3 Ershov, Sovetskaia satiricheskaia proza 20-kh godov, p. 163. Also see p. 168 . He repeats this argument in Leonid Ershov, Istoriia russkoi sovetskoi literatury, 2nd edn, rev., Moscow: Vysshaia shkola, 1988, p. 110. Ershov sees this irony as a tool of political satire and a way of highlighting the contradictions between the old and the new elements of Soviet society, and the shortcomings of the character. He does not contemplate the possibility that it could be an expression of a world-view with wider scope.

4 The story is thus dependent on an untranslatable double meaning in the word 'schast'e', luck and happiness: a stroke of luck has made Ivan Fomich happy.

5 Mikhail Zoshchenko, Rasskazy, Moscow: Khudozhestvennaia literatura, 1974, pp. 126-29.

6 Chukovskii corroborates the Zoschenko's own testament to mental illness, Pered voskhodom solntsa. Chukovskii, 'Iz vospominanii'; Mikhail Zoshchenko, Pered voskhodom solntsa, SS III, pp. 447-693.

7 Broadly, Scatton, Sarnov and Zholkovsky stress the similarities, whereas Starkov, Kreps, and Chudakova stress the dissimilarities.

8 Typical examples are: Starkov, Mikhail Zoshchenko: sud ba khudozhnika; Moldavskii, Mikhail Zoshchenko: ocherk tvorchestva

9 Sarnov stands almost alone in treating Zoshchenko as a genuine aesthetic revolutionary. Unfortunately, he fails to pay sufficient attention to Zoshchenko's parodic intent. Sarnov, Prishestvie kapitana Lebiadkina (Sluchai Zoshchenko), passim. 
10 In a letter to Gor' kii in 1930, Zoshchenko questions the way in which he had responded to the readers in Pis'ma k pisateliu, claiming that he had been insincere. Gor kii i sovetskie pisateli: neizdannaia perepiska, p. 163.

11 See T. Ivanova, 'O Zoshchenko', in Vospominaniia o Mikhaile Zoshchenko, pp. 178-89; I Metter, 'Svidetel'stvo sovremennika', in Vospominaniia o Mikhaile Zoshchenko, pp. 242-59; N. Krymova, 'Iakhontov chitaet Maiakovskogo i Zoshchenko', Neva, 6 (1977), pp. 195-210.

12 Mikhail Zoshchenko, 'O komicheskom v proizvedeniiakh Chekhova', Voprosy literatury, 2 (1967), $152-55$ (p. 152).

13 This devaluation of humour as universal, classless, ideology-free and therefore irrelevant, is a common Soviet definition. In it, satire is awarded pride of place as a tool of social critique and a weapon of class warfare, whereas irony is seen as nihilistically ambiguous. See, for example: Ershov, Sovetskaia satiricheskaia proza 20-kh godov, p. 166. This is an extreme variant of a more common distinction between types of satire. See, for example, Ronald Paulson: 'One is a wild, not quite stable comedy; the other a moral condemnation.' Ronald Paulson, The Fictions of Satire, Baltimore MD: John Hopkins Press, 1967, p. 3.

14 Quoted in Arthur Pollard, Satire, London: Methuen, 1970, p. 73.

15 Gogol', Polnoe sobranie sochinenii, IV, p. 94. For a discussion of the misunderstanding of his work see, for example, Jesse Zeldin, Nikolai Gogol's Quest for Beauty: An Exploration into his Works, Lawrence: The Regent's Press of Kansas, 1978, p. 68.

16 Chekhov expressed this view most explicitly in a letter to Suvorin of 30 May 1888: Anton Chekhov, Polnoe sobranie sochinenii i pisem v tridtsati tomakh, ed. N. F. Bel'chikov et al., Moscow: Nauka, 1974-83, Pis'ma, II, pp. 280-81.

17 Chukovskii, 'Iz vospominanii', p. 77.

18 'Kak ia rabotaiu', Uvazhaemye grazhdane, p. 590.

19 See Scatton, Mikhail Zoshchenko: Evolution of a Writer, Chapter I, pp. 3-10. Also see Zholkovsky, “"What is the Author trying to say With his Artistic Work?"'; and Zholkovsky, Mikhail Zoshchenko: poetika nedoveriia. 


\section{Bibliography}

This bibliography comprises the following sections.

1) Zoshchenko: i) Primary Sources ii) Secondary Sources

2) The 1920s: Cultural and Historical Context

3) Skaz Writers Referred to

4) The Theory and History of Skaz

5) Other Literary Theory and History

6) Reference and Other Works Consulted

\section{1) Zoshchenko}

It is not my intention to provide an exhaustive bibliography of Zoshchenko's work.

Instead, I list the most authoritative and comprehensive editions of his work and the sources of other works and variants I have made reference to.

\section{i) Primary Sources}

\section{Editions of Zoshchenko's Works (A Selection)}

Zoshchenko, Mikhail, Uvazhaemye grazhdane, 7th edn, Moscow: Zemlia i fabrika, 1927.

, Sobranie sochinenii, 6 vols, Moscow and Leningrad: Priboi-GIKhL, 1929-

32.

, Rasskazy, povesti, fel'etony, teatr, kritika, 1935-37, Leningrad:

Khudozhestvennaia literatura, 1937.

Izbrannye proizvedeniia $v$ dvukh tomakh, Leningrad: Khudozhestvennaia

literatura, 1968.

, Rasskazy, Moscow: Khudozhestvennaia literatura, 1974.

, Sobranie sochinenii v trekh tomakh, ed. Iurii Tomashevskii, Leningrad:

Khudozhestvennaia literatura, 1986. 
, Uvazhaemye grazhdane: parodii, rasskazy, fel'etony, satiricheskie zametki.

Pis'ma k pisateliu, odnoaktnye komedii, ed. Mikhail Dolinskii, Moscow:

Knizhnaia palata, 1991.

, Sobranie sochinenii v piati tomakh, ed. Iurii Tomashevskii, Moscow:

Russlit, 1994.

Zoshchenko, Mikhail and Vera, Neizdannyi Zoshchenko, ed. Vera von Wiren, Ann

Arbor MI: Ardis, n.d.

\section{Other Works and Variants Referred to}

Pavlovskii, A. I. (ed.), 'Stat'ia M. M. Zoshchenko o B. K. Zaitseve'[1919], in N. A. Groznova (ed.), Mikhail Zoshchenko: materialy $k$ tvorcheskoi biografii (kniga pervaia), St Petersburg: Nauka, 1997, pp. 37-48.

'Neizvestnyi drug', Drezina, 9 (1923).

'Sobachii niukh', Smekhach, 1 (1924).

'Plokhoi obychai', Krasnyi voron, 11 (1924).

'Tiazhelye vremena', Begemot, 4 (1925).

'Bania', Begemot, 10 (1925).

'Gor'kii - Zoshchenko' [correspondence 1927 to 1936], in I. I. Anisimov et al. (eds), Gor'kii i sovetskie pisateli: neizdannaia perepiska, Literaturnoe nasledstvo, Moscow: Akademiia Nauk SSSR, 1963, LXX, 157-68.

'O komicheskom v proizvedeniiakh Chekhova'[1944],Voprosy literatury, 2 (1967), $152-55$.

\section{English Translations}

Zoshchenko, Mikhail, Russia Laughs, tr. Helena Clayton with a foreword by Whit Burnett, Boston: Lothrop, 1935. The Woman Who Could Not Read And Other Tales, tr. Elizaveta Fen, London: Methuen, 1940. 
, Scenes from the Bathhouse and Other Stories of Communist Russia, tr.

with an introduction by Sidney Monas; stories selected by Marc Slonim, Ann

Arbor MI: Ann Arbor Paperbacks and University of Michigan Press, 1962.

, Nervous People and Other Satires, ed. with an introduction by Hugh

McLean, tr. Hugh McLean and Maria Gordon, London: Gollancz, 1963.

Before Sunrise: A Novella, tr. with an afterword by Gary Kern, Ann Arbor

MI: Ardis, 1974.

, Youth Restored, tr. Joel Stern, Ann Arbor MI: Ardis, 1984.

, A Man is not a Flea, tr. Serge Shishkoff, Ann Arbor MI: Ardis, 1989.

\section{ii) Secondary Sources}

Abdulaeva, Z., 'V maske ryzhego', Znanie - sila, 6 (1995), 123-30.

Andersin-Suni, Tiina and Timo Suni, 'O Rasskazakh Sinebriukhova M. Zoshchenko v kontekste postmoderna', in Pekka Pesonen (ed.), Modernizm i postmodernizm v russkoi literature i kul'ture, Helsinki: University of Helsinki Press, 1996, 361-73.

Annenkov, Iurii, Dnevnik moikh vstrech: tsikl tragedii, 2 vols, New York: Inter-

Language Literary Associates, 1966, I, 310-21.

Antonov, Sergei, 'Golubaia kniga Mikhaila Zoshchenko', Neva, 12 (1973), 115-30.

Ardov, Mikhail (protoerei), 'Legendarnaia Ordynka', Novyi mir, 4 (1994), 3-43 and 5 (1994), 113-56.

Bakinskii, Viktor, 'Mikhail Zoshchenko: iz zapiski sovremennika', Neva, 12 (1988), 196-200.

Baranov, Vadim, 'The Inevitability of Purification', Soviet Literature, 2 (1989), 133 37.

Belaia, Galina, 'Umnaia ironiia Zoshchenko', review of Mikhail Zoshchenko, Rasskazy, Moscow, 1974, Novyi mir, 9 (1975), 258-62. 
, 'Stil' i vremia ("Avtoritetnyi stil"' i ego "problematika")' in N. K. Gei et al. (eds), Teoriia literaturnykh stilei: mnogoobrazie stilei sovetskoi literatury. Voprosy tipologii, Moscow: Nauka, 1978, 231-56.

, 'Rozhdenie novykh stilevykh form kak protsess preodoleniia

"neitral'nogo" stilia', in N. K. Gei et al. (eds), Teoriia literaturnykh stilei:

mnogoobrazie stilei sovetskoi literatury. Voprosy tipologii, Moscow: Nauka, 1978, 460-86.

, 'Eksistentsial'naia problematika tvorchestva M. Zoshchenko',

Literaturnoe obozrenie, 1 (249) (1995), 4-13; tr.: 'The Existential Problematic of the Work of Mikhail Zoshchenko', Russian Studies in Literature, 33/1 (Winter 1996-1997), 5-25.

Beskina, Anna, 'Litso i maska Mikhaila Zoshchenko', Literaturnyi kritik, 1 (1935), $107-31$ and 2 (1935), 59-91.

Booker M. Keith and Dubravka Juraga, 'Language, Genre and Satire in the Works of Mikhail Zoshchenko', in Keith M. Booker and Dubravka Juraga, Bakhtin, Stalin and Modern Russian Fiction: Carnival, Dialogism and History, Westport CT: Greenwood Press, 1995, 83-102.

Carleton, Gregory Steven, 'Problems of Text and Reception: Mixail Zoščenko', unpublished doctoral thesis, University of Michigan, 1992. , The Politics of Reception: Cultural Constructions of Mikhail Zoshchenko, Evanston IL: Northwestern University Press, 1998.

Cherniak, V. D., 'Marginal'naia iazykovaia lichnost' v rasskazakh Mikhaila Zoshchenko 20-30-kh godov', in Literaturnaia gruppa "Serapionovy brat 'ia": istoki, poiski, traditsii, mezhdunaradnyi kontekst, tezisy dokladov mezhdunarodnoi konferentsii, St Petersburg, 13-16 marta 1995 goda, St Petersburg: Institut russkoi literatury Rossiiskoi Akademii Nauk (Pushkinskii dom), 1995, 42-44. Chudakova, Marietta, Poetika Mikhaila Zoshchenko, Moscow: Nauka, 1979. 
Chukovskaia, Elena (ed.), with an introduction by Benedikt Sarnov, 'Zoshchenko v dnevnikakh Chukovskogo', Znamia, 6 (1987), 185-96.

Cukierman, Jacqueline Decter, 'Mixail Zoščenko's Rasskazy and Povesti of the 1920s: A Study in Genre Evolution', unpublished doctoral thesis, University of Michigan, 1978.

Domar, Rebecca, 'The Tragedy of a Soviet Satirist: The Case of Zoshchenko', in Ernest J. Simmons (ed.), Through the Glass of Soviet Literature, New York: Oxford University Press, 1953.

Erlich, Victor, 'The Masks of Mikhail Zoshchenko', Stanford Slavic Studies, 4/2 (1992), 157-76.

Ershov, Leonid, Sovetskaia satiricheskaia proza 20-kh godov, Moscow-Leningrad: Akademiia Nauk, 1960.

, M. Zoshchenko i satiricheskaia proza 20-40-kh godov, Leningrad: Nauka, 1973.

Eventov, I., 'Iumor Mikhaila Zoshchenko', Neva, 10 (1968), 166-72.

Fediakin, S., 'Rozanov i Zoshchenko: dva puti preodoleniia literatury', Literaturnoe obozrenie, 1 (249) (1995), 58-61.

Filippova, A., 'Dramaturgiia M. Zoshchenko 40-kh: osobennosti konflikta', Literaturnoe obozrenie, 1 (249) (1995), 29-33.

France, Rose, 'The Speaking Author: Skaz in Mikhail Zoshchenko's Sentimental Tales', Essays in Poetics, 21 (Autumn 1996), 35-49; also in Dietrich Scheunemann (ed.), Orality, Literacy, and Modern Media, Columbia SC: Camden House, 1996, $62-76$.

Goller, Agota N., 'Parodiia i tsitatsiia v "Sentimental'nykh povestiakh” M. Zoshchenko', Studia Slavica Academiae Scientiarum Hungaricae, 38/1-2 (1993), $67-75$.

Golovanova, E., 'Mif o proletarskom pisatele: tvorcheskaia sud'ba Vsevoloda Ivanova i Mikhaila Zoshchenko', Literaturnoe obozrenie, 1 (249) (1995), 55-57. 
Gorbachev, Georgii, Ocherki sovremennoi russkoi literatury, 2nd edn, Leningrad: Gosizdat, 1924. , Sovremennaia russkaia literatura, 3rd edn, Moscow and Leningrad: Gosizdat khudozhestvennoi literatury, 1931.

Grigor'ev, K. (ed.), 'Pis'ma Mikh. Zoshchenko', Voprosy literatury, 4 (1982), 28082.

Groznova, N. A. (ed.), Mikhail Zoshchenko: materialy k tvorcheskoi biografii (kniga pervaia), St Petersburg: Nauka, 1997.

Günther, Hans, 'Zur Semantik und Funktion des Skaz bei M. Zoščenko', in Gernot Erler et al. (eds), Von der Revolution zum Schrifftsteller Kongreß, Berlin: OstEuropa Institut, 1979, 326-53.

Hanson, Krista, 'P. Sh. Diubua i Zoshchenko: "ratsional'naia pskhoterapiia" kak istochnik zoshchenkovskoi psikhologicheskoi teorii', Literaturnoe obozrenie, 1 (249) (1995), 62-65.

Kadash, T., "“Zver” i "nezhivoi chelovek” v mire rannego Zoshchenko', Literaturnoe obozrenie, 1 (249) (1995), 36-38.

Katowitz, Carol Schrier, 'A Study of the Character and Function of the NarratorParticipant in Selected Short Stories of Mixail Zoščenko', unpublished doctoral thesis, University of Pennsylvania, 1972.

Kazanskii, B. and Iurii Tynianov (eds), Mikhail Zoshchenko: stat i i materialy, Leningrad: Academia; 1928; repr. Ann Arbor MI: Ardis, n.d..

Kern, Gary and Christopher Collins (eds), The Serapion Brothers: A Critical Anthology, Ann Arbor MI: Ardis, 1975.

Kornienko, N., 'Zoshchenko i Platonov: vstrechi v literature', Literaturnoe obozrenie, 1 (249) (1995), 47-54.

Kreps, Mikhail [Michael Boris], 'Mixail Zoščenko as Humorist and Satirist: A Structural Approach', unpublished doctoral thesis, Berkeley: University of California, 1981. 
, Tekhnika komicheskogo u Zoshchenko, Benson VT: Chalidze, 1986.

Krymova, N., 'Iakhontov chitaet Maiakovskogo i Zoshchenko', Neva, 6 (1977), 195210.

Kuliapin, A., '“Zamaskirovan smekhom” (M. Zoshchenko i F. Nitsshe)', Zvezda, 8 (1995), 198-201.

Lavut, Pavel, 'Zoshchenko na estrade', Nedelia, 33 (805) (1975), p. 15.

McLean, Hugh, 'Introduction', in Mikhail Zoshchenko, Nervous People and Other Satires, ed. and intro. by Hugh McLean, tr. Maria Gordon and Hugh McLean, London: Gollancz, 1963, vii-xxviii.

Masing-Delic, Irene, 'Nastavnichestvo Gor'kogo i "metamorfoza" Zoshchenko', Literaturnoe obozrenie, 1 (249) (1995), 39-44. tr.: 'Gorky's Tutorship and Zoshchenko's “Metamorphosis,"' Russian Studies in Literature, 33/2, (Spring 1997), 49-59.

Metter, I., 'Pri zhizni byt' ne knigoi, a tetradkoi', Voprosy literatury, 7 (1988), 22838.

Milne, Lesley, 'Rasskazy o Lenine', Literaturnoe obozrenie, 1 (249) (1995), 45-46.

Moldavskii, Dmitrii, Mikhail Zoshchenko: ocherk tvorchestva, Leningrad: Sovetskii pisatel’, 1977.

Monas, Sidney, 'Introduction', in Mikhail Zoshchenko, Scenes from the Bathhouse and Other Stories of Communist Russia, tr. with an introduction by Sidney Monas, Ann Arbor MI: Ann Arbor Paperbacks and University of Michigan Press, 1962, vxvii.

Muromskii, V., 'Sud'ba dramaticheskogo naslediia M. M. Zoshchenko', Russkaia Literatura, 2 (1996), 90-106.

Murphy, A. B., Mikhail Zoshchenko: A Literary Profile, Oxford: W. A. Meeuws, 1981. 
Novikov, V., 'O meste Zoshchenko v russkoi literature (Predshestvenniki i posledovateli ot Daniila Zatochnika do Mikhaila Zvanetskogo)', Literaturnoe obozrenie, 1 (249) (1995), 25-27.

Orlova, E. I., 'Posle skaza: Mikhail Zoshchenko-Venedikt Erofeev-Abram Terts', Filologicheskie nauki, 6 (1996), 13-22.

Oulanoff, Hongor, The Serapion Brothers: Theory and Practice, The Hague: Mouton, 1966.

Paramonov, Boris, 'Zoshchenko v teatre', Znamia, 7 (1995), 208-16.

Pecherskii, S., 'Tsenzorskaia pravka "Goluboi knigi” Zoshchenko', Minuvshee: istoricheskii al'manakh, 3 (1987), 355-91.

Penskaia, E., 'M. Zoshchenko i teatr absurda', Literaturnoe obozrenie, 1 (249) (1995), 34-35.

Perkhina, V. (ed.), “"Chuvstvo ironii ochen” ostroe...” Sovremenniki o Mikhaile Zoshchenko', Neva, 8 (1994), 303-309.

Petrenko, Mikhail, 'Why do I Love the Grotesque?', Soviet Literature, 2 (1989), 177 83.

Popkin, Cathy, The Pragmatics of Insignificance: Chekhov, Zoshchenko, Gogol, Stanford CA: Stanford University Press, 1993. , “Ne govoria uzhe o nogakh": "Nizhnie konechnosti” v slovare Zoshchenko', Literaturnoe obozrenie, 1 (249) (1995), p. 28.

Sarnov, Benedikt, Smotrite, kto prishel: novyi chelovek na arene istorii, Moscow: Novosti, 1992. , Prishestvie kapitana Lebiadkina (Sluchai Zoshchenko), Moscow: Pik Rik;

Kul'tura, 1993. , “'Razvivaia traditsiiu Prokrusta” (Mikhail Zoshchenko i ego redaktory)', Voprosy literatury, 2 (1994), 45-91.

Scatton, Linda Hart, Mikhail Zoshchenko: Evolution of a Writer, Cambridge: Cambridge University Press, 1993. 
, 'Ne do smekha: problema tvorcheskoi evoliutsii Mikhaila Zoshchenko', Literaturnoe obozrenie, 1 (249) (1995), 14-17; tr.: 'No Laughing Matter: The Creative Evolution of Mikhail Zoshchenko', Russian Studies in Literature, 33/1 (Winter 1996-1997), 26-32.

, 'Writing For the New Reader', in Nicholas Luker (ed.), After the Watershed:

Russian Prose 1917-1927: Selected Essays, Nottingham: Astra Press, 1996, 93-

106.

Scriabine, Hélène, 'L'Humour contre les "faux dieux" dans l'oeuvre de deux grands contemporains Michel Zotchenko et Marcel Aymé', unpublished doctoral thesis, Syracuse University, 1962.

Shaitanov, I., 'Mezhdu eposom i anekdotom', Literaturnoe obozrenie, 1 (249) (1995), 18-24; tr.: 'Between Epos and Anecdote', Russian Studies in Literature, 33/1 (Winter 1996-1997), 33-38.

Shcheglova, Evgeniia, 'Triumf i tragediia Mikhaila Zoshchenko', Neva, 8 (1994), 258-66.

Shcheglov, Iurii, 'Mir Mikhaila Zoshchenko', Wiener Slawistischer Almanach, 7 (1981), 109-54.

, 'Entsiklopediia nekul'turnosti: Zoshchenko: rasskazy 1920-kh godov i

"Golubaia kniga", in A. K. Zholkovsky and Iu. K. Shcheglov, Mir avtora $i$

struktura teksta: stat i o russkoi literature, Tenafly NJ: Hermitage, 1986, 53-84;

tr.: 'An Encyclopedia of Unculturedness: Zoshchenko: Stories of the 1920s and

The Sky Blue Book', Russian Studies in Literature, 33/2, (Spring 1997), 4-25.

Shoshin, V. A., “O nekotorykh neizvestnykh nabroskakh i zamyslakh M. M.

Zoshchenko', in Literaturnaia gruppa "Serapionovy brat 'ia": istoki, poiski, traditsii, mezhdunarodnyi kontekst; tezisy dokladov mezhdunarodnoi konferentsii, St Petersburg, 13-16 marta 1995 goda, St Petersburg: Institut russkoi literatury Rossiiskoi Akademii Nauk (Pushkinskii dom), 1995, 35-39. 
Siniavskii, Andrei, ‘Mify Mikhaila Zoshchenko', Voprosy literatury, 2 (1989), 50-67; tr.: 'The Myths of Mikhail Zoshchenko', Russian Studies in Literature, 33/1 (Winter 1996-1997), 39-58.

Starkov, Anatolii, 'Ot "Sinebriukhova", k "Goluboi knige” (Satira M. M. Zoshchenko v 20-kh-pervoi polovine 30-kh godov; evoliutsiia skaza)', Voprosy literatury, 11 (1964), 64-82. , Iumor Zoshchenko, Moscow: Khudozhestvennaia literatura, 1974. , Mikhail Zoshchenko: sud'ba khudozhnika, Moscow: Sovetskii pisatel', 1990.

Starosel'skaia, Natal'ia, 'Osvetitel' spektaklia zhizni', Voprosy literatury, 5 (1996), $36-55$.

Sven, Viktor, Chei drug i chei vrag Mikhail Zoshchenko? Munich: Tsentr. ob"edineniia politicheskikh emigrantov iz SSSR (TSOPE), 1958.

Titunik, Irwin, 'Mixail Zoščenko and the Problem of Skaz', California Slavic Studies, 4 (1971), 83-96.

Tomashevskii, Iurii, 'Zoshchenko-zhurnalist', Voprosy literatury, 7 (1984), 253-68. , “Literatura dolzhna byt' narodnoi”: iz tvorcheskogo naslediia M. M Zoshchenko', Literaturnoe obozrenie, 9 (1984), 100-08. , 'Iz pisem i dnevnikovykh zapisei 1919-1921 godov', Novyi mir, 11 (1984), 211-29.

, 'Ob odnom posviashchenii: popytka psikhologicheskogo kommentariia', Oktiabr', 10 (1985), 195-200. , 'Primechaniia', in Mikhail Zoshchenko, Sobranie sochinenii v trekh tomakh, ed. Iurii Tomashevskii, Leningrad: Khudozhestvennaia literatura, 1986, I, 538-39. , “'Ia vzial podriad na etot zakaz...”: M. M. Zoshchenko o literature i ee iazyke', Russkaia rech', 5 (1987), 55-64. 
(ed.), 'Pisatel' s perepugannoi dushoi eto uzhe poteria kvalifikatsii: M. M. Zoshchenko: Pis’ma, vystuplenie, dokumenty 1943-1958 godov', Druzhba narodov, 3 (1988), 168-89. (ed.), ‘Neizvestnyi sovetskii grazhdanin, kotorogo zvali Zoshchenko: po stranitsam emigrantskikh izdanii 1920-1930-kh', Druzhba narodov, 8 (1993), 20016. (ed.), Litso i maska Mikhaila Zoshchenko, Moscow: Olimp, 1994. 'Zoshchenko i "ego" Serapionovy brat ia', in Literaturnaia gruppa

"Serapionovy brat ia": istoki, poiski, traditsii, mezhdunarodnyi kontekst; tezisy dokladov mezhdunarodnoi konferentsii, St Petersburg, 13-16 marta 1995 goda, St Petersburg: Institut russkoi literatury Rossiiskoi Akademii Nauk (Pushkinskii dom), 1995, 33-34. (ed.), Vospominaniia o Mikhaile Zoshchenko, St Petersburg:

Khudozhestvennaia literatura, 1995. ,'Zhizn' posle smerti, ili Vospominanie o budushchem Mikhaila

Zoshchenko', Literaturnoe obozrenie, 1 (254) (1996), 54-62.

Vinogradov, Viktor, 'Iazyk Zoshchenki (zametki o leksike)', in Iurii Tynianov and B. Kaganskii (eds), Mikhail Zoshchenko: stat i i materialy, Leningrad: Academiia, 1928; repr. Ann Arbor MI: Ardis, no date, 51-92.

Vol'pe, Tsezar', Kniga o Zoshchenko [1940], repr. in Iskusstvo nepokhozhesti, Moscow: Sovetskii pisatel', 1991, 141-316.

Von Wiren-Garczynski, Vera, 'The Russian Language in the Immediate PostRevolutionary Period (1919-1928) and its Literary Stylization in the Fiction of Mixail Zoščenko', unpublished doctoral thesis, New York University, 1965. Zholkovsky, Alexander; Text Counter Text: Rereadings in Russian Literary History, Stanford CA: Stanford University Press, 1994. , 'Ruka blizhnego i ee mesto v poetike Zoshchenko', Novoe literaturnoe obozrenie, 15 (1995), 262-86. 
, 'K reinterpretatsii poetiki Mikhaila Zoshchenko ("Entsiklopediia strakha”

i ideinaia struktura rasskaza “Dushevnaia prostota")', Izvestiia Akademii Nauk:

seriia literatury i iazyka, 54/5 (1995), 50-60; tr.: 'Reinterpreting Zoshchenko: The

Case of “Soul's Simplicity”, Russian Studies in Literature, 33/2 (Spring 1997),

41-48.

, 'Zubnoi vrach, korystnaia molochnitsa, intelligentnyi monter i ikh avtor:

krepkovatyi brak v mire Zoshchenko', Literaturnoe obozrenie, 5-6 (259-260)

(1996), 128-44.

, “"What is the Author Trying to Say With His Artistic Work?" Rereading

Zoshchenko's Oeuvre', Slavic and East European Journal, 40/3, (Autumn 1996), 458-474.

'Food, Fear, Feigning, and Flight in Zoščenko's “Foreigners"', Russian

Literature, 40/3, (1996), 385-404.

,'Zoshchenko's “Electrician”, or the Complex Theatrical Mechanism',

Russian Studies in Literature, 33/1 (Winter 1996-1997), 59-79.

, 'K pereosmysleniiu kanona: sovetskie klassiki-nonkonformisty $\mathrm{v}$

postsovetskoi perspektive', Novoe literaturnoe obozrenie, 29 (1998), 55-68.

, Mikhail Zoshchenko: poetika nedoveriia, Moscow: Shkola, 1999.

Zhurbina, Evgeniia, 'Mikhail Zoshchenko', in Sobranie sochinenii, 6 vols, Moscow

and Leningrad: Priboi-GIKhL, 1929-32, I, 1-20.

\section{2) 1920s: The Cultural and Historical Context}

Barooshian, Vahan D., Russian Cubo-Futurism 1910-1930: A Study in Avant-

Gardism, The Hague: Mouton, 1974.

Barnouw, Erik, Documentary: A History of the Non-Fiction Film, 2nd edn, rev., Oxford: Oxford University Press, 1993. 
Belaia, Galina, 'Problema aktivnosti stilia: $\mathrm{k}$ issledovaniiu istoricheskoi produktivnosti stilei 20-kh godov', in S. Bocharov et al. (eds), Smena literaturnykh stilei, Moscow: Nauka, 1974, 122-77. , Zakonomernosti stilevogo razvitiia sovetskoi prozy 20-kh godov, Moscow: Nauka, 1977.

Boym, Svetlana, Common Places: Mythologies of Everyday Life in Russia, Cambridge MA: Harvard University Press, 1994.

Brooks, Jeffrey, When Russia Learned to Read: Literacy and Popular Culture, 1861 1917, Princeton NJ: Princeton University Press, 1985. , 'Public and Private Values in the Soviet Press, 1921-1928', Slavic Review, 48/1 (Spring 1989), 16-35.

, 'The Press and its Message: Images of America in the 1920s and 1930s', in Sheila Fitzpatrick et al. (eds), Russia in the Era of NEP: Explorations in Soviet Society and Culture, Bloomington: Indiana University Press, 1991, 231-52.

Brovkin, Vladimir, Russia After Lenin: Politics, Culture and Society, 1921-1929, London: Routledge, 1998.

Brown, Edward J., Russian Literature Since the Revolution, 2nd edn, rev. and enlarged, Cambridge MA: Harvard University Press, 1982.

Carleton, Greg, 'Genre in Socialist Realism', Slavic Review, 53/4 (1994), 992-1009.

Carr, Edward, The Interregnum 1923-24, London: Macmillan, 1954.

Chapple, Richard L., Soviet Satire of the Twenties, Gainsville: University of Florida, 1980.

Chuzhak, Nikolai (ed.), Literatura fakta: pervyi sbornik materialov rabotnikov LEFa, Moscow: Federatsiia, 1929; repr. Munich: Wilhelm Fink, 1972.

Clark, Katerina, The Soviet Novel: History as Ritual, Chicago IL: University of Chicago Press, 1981.

Cliff, Tony, Trotsky: Fighting the Rising Stalinist Bureaucracy 1923-1927, London: Bookmarks, 1991. 
Dolgov, A. P., 'Satiriko-iumoristicheskii rasskaz v 20-e gody', in Faina Kanunova, et al. (eds), Problemy literaturnykh zhanrov: materialy tret'ei mezhvuzovskoi konferentsii 6 fevralia - 9 fevralia 1979 goda, Tomsk: Izd. Tomskogo universiteta, $1979,147-48$.

Ershov, Leonid, Satiricheskie zhanry russkoi sovetskoi literatury (ot epigrama do romana), Leningrad: Nauka, 1977.

, Istoriia russkoi sovetskoi literatury, 2nd edn, rev., Moscow: Vysshaia shkola, 1988

Fitzpatrick, Sheila, 'The Problem of Class Identity in NEP Society', in Sheila Fitzpatrick et al. (eds), Russia in the Era of NEP: Explorations in Soviet Society and Culture, Bloomingtoon: Indiana University Press, 1991, 12-33.

Golubkov, M. M., Utrachennye al'ternativy: formirovanie monisticheskoi kontseptsii sovetskoi literatury; 20-30-e gody, Moscow: Nasledie, 1992.

Gorham, Michael S., 'Tongue-Tied Writers: The Rabsel'kor Movement and the Voice of the "New Intelligentsia" in Early Soviet Russia', Russian Review, 55 (July 1996), 412-29.

Gor kii, Maksim, Sobranie sochinenii v tridtsati tomkh, Moscow: Khudozhestvennaia literatura, 1949-55.

Groznova, N. A., Ranniaia sovetskaia proza 1917-1925, Leningrad: Nauka, 1976.

Günther, Hans, 'Literatura fakta', Russian Literature, 17 (1985), 21-28.

Kenez, Peter, The Birth of the Propaganda State: Soviet Methods of Mass Mobilization 1917-1929, Cambridge: Cambridge University Press, 1985.

Kern, Gary, 'The Serapion Brothers: A Dialectics of Fellow Travelling', Russian Literature Triquarterly, 2 (1972), 223-47.

Kolchevska, Natasha. "Toward a "Hybrid" Literature: Theory and Praxis of the Faktoviki', Slavic and East European Journal, $27 / 4$ (1983), 452-64. 
Lawton, Anna (ed.), Russian Futurism Through its Manifestoes, 1912-1928, texts ed. and tr. Anna Lawton and Herbert Eagle, Ithaca NY: Cornell University Press, 1988.

Lezhnev, A., Sovremenniki: literaturno-kriticheskie ocherki, Moscow: Krug, 1927.

Maguire, Robert, Red Virgin Soil: Soviet Literature in the 1920s, Princeton NJ: Princeton University Press, 1968.

Maiakovskii, Vladimir and Osip Brik, 'Nasha slovesnaia rabota', Lef, 11 (1923), 4041.

Maiakovskii, Vladimir, 'Kak delat' stikhi', in Vladimir Maiakovskii, Polnoe sobranie sochinenii v trinadtsati tomakh, Moscow: Khudozhestvennaia literatura, 1956-61, XII, 81-117.

Nilsson, Nils-Åke, 'Futurism, Primitivism and the Russian Avant-Garde', Russian Literature, 8 (1980), 469-82.

O partiinoi i sovetskoi pechati: sbornik dokumentov, Moscow: Pravda, 1954, 245-46.

Ozmitel', E. K., Sovetskaia satira: seminarii; posobie dlia studentov, Moscow and Leningrad: Prosveshchenie, 1964.

Partiinaia $i$ sovetskaia pechat' $v$ bor be za postroenie sotsializma $i$ kommunizma:uchebnoe posobie, 2nd edn, rev., Moscow: Mysl’, 1966.

Pethybridge, Roger, One Step Backwards Two Steps Forward: Soviet Society and Politics in the New Economic Policy, Oxford: Clarendon Press, 1990.

Petrić, Vlada, Constructivism in Film: The Man with The Movie Camera: A Cinematic Analysis, Cambridge: Cambridge University Press, 1987.

Philips, Laura L., 'Message in a Bottle: Working Class Culture and the Struggle for Revolutionary Legitimacy, 1900-1929', Russian Review, 56/1 (Jan 1997), 25-43

Raskol'nikov [Il`in], Fedor Fedorovich, 'Rabkory i proletarskaia literatura', Na postu, 1 (6) (June 1925), 105-112; repr. Munich: Wilhelm Fink, 1971, 105-112.

Russell, Robert, Russian Drama of the Revolutionary Period, London: Macmillan, 1988. 
Scherr, Barry, 'Notes on Literary Life in Petrograd, 1918-1922: A Tale of Three Houses', Slavic Review, 36/2 (1977), 256-67.

Serapionovy brat'ia: al'manakh pervyi, St Petersburg: Alkonost, 1922.

Skelley, Eva (gen. ed.), Anthology of Soviet Satire in Two Volumes, I: Peter Henry (ed.), Classics of Soviet Satire, London: Collet's, 1972.

Skobelev, V. P., Massa i lichnost'v russkoi sovetskoi proze 20-kh godov (K probleme narodnogo kharaktera), Voronezh: Izd. Voronezhskogo gosudarstvennogo universiteta, 1975.

Skorospelova, E. B., Ideino-stilevye techeniia v russkoi sovetskoi proze pervoi poloviny 20-kh godov, Moscow: Moskovskii gosudarstvennyi universitet, 1979.

SSSR v period vosstanovleniia narodnogo khoziaistva (1921-1925 godov): istoricheskie ocherki, Moscow: Politicheskaia literatura, 1955.

Stykalin S. and Kremenskaia, I., Sovetskaia satiricheskaia pechat’1917-1963, Moscow: Politlit, 1963.

Trotskii, Lev, 'Gazeta i ee chitatel', in Voprosy byta: epokha 'kul'turnichestva' i ee zadachi, 3rd edn, Moscow: Gosizdat, 1923, 19-30.

Von Wiren-Garczynski, Vera, 'Language and Revolution: The Russian Experience of the Twenties', Canadian Slavic Studies, 2/2 (1968), 192-207.

Zakharieva, Irina, Khudozhestvennyi sintez $v$ russkoi proze XX veka (20-e-pervaia polovina 50-kh godov), Sofiia: Biblioteka 48, 1994.

Zhanry sovetskoi gazety, Moscow: Vysshaia shkola, 1972.

Zhurbina, Evgeniia, Teoriia i praktika khudozhestvenno-publitsisticheskikh zhanrov: ocherk, fel'eton, Moscow: Mysl', 1969.

\section{3) Skaz Writers Referred to}

Babel', Isaak, Sochineniia $v$ dvukh tomakh, ed. A. N. Pirozhkovaia with an introduction by G. A. Belaia and commentary by S. N. Povartsov, Moscow: Khudozhestvennaia literatura, 1990. 
Bazhov, Pavel, Malakhitovaia shkatulka, ed. L. Skorino, Moscow: Sovetskii pisatel', 1947.

Belyi, Andrei, Sobranie sochinenii: Serebriannyi golub', rasskazy, ed. V. M.

Piskunov, Moscow: Respublika, 1995.

Dal', Vladimir [Kazak Luganskii], Izbrannye proizvedeniia, Moscow: Pravda, 1983. , Povesti i rasskazy, Moscow: Sovetskaia Rossiia, 1983.

, Polnoe sobranie sochinenii v vos'mi tomakh, ed. V. Ia Deriagin and Z. S.

Deriagina, Moscow: Stolitsa, 1995.

Fedin, Konstantin, Sobranie sochinenii v desiati tomakh, ed. I. Chekhovskaia, Moscow: Khudozhestvennaia literatura, 1973.

Gogol', Nikolai, Polnoe sobranie sochinenii, ed. I. I. Lazarevskii, 14 vols, Moscow and Leningrad: Akademiia Nauk, 1937-52.

Gorbunov, Ivan F., Iumoristicheskie rasskazy i ocherki, Moscow: Moskovskii rabochii, 1962.

Leonov, Leonid, Sobranie sochinenii v deviati tomakh, ed. V. Borisova, Moscow: Khudozhestvennaia literatura, 1960.

Leskov, Nikolai, Sobranie sochinenii v odinnadtsati tomakh, ed. V. G. Bazanov, Moscow: Khudozhestvennaia literatura, 1956.

Remizov, Aleksei, Rasskazy, ed. Dmitrii Chizhevskii, 4 vols, St Petersburg: Shipovnik 1910-12; repr. Munich: Wilhelm Fink, 1971. , Izbrannye proizvedeniia, ed. with notes by M. Kozmenko and I.

Kashirinaia, preface by M. Kozmenko, Moscow: Panorama, 1995.

Shishkov, Viacheslav, Sobranie sochinenii v desiati tomakh, ed. N. Eselev, Moscow: Pravda, 1974.

Zamiatin, Evgenii, Sochineniia, ed. E. Zhiglevich with an introduction by A. Kashina, 4 vols, Munich: A. Neimanis, 1970. , Izbrannye proizvedeniia, ed. with an introduction and notes by $\mathrm{E}$.

Skorospelova, Moscow: Sovetskaia Rossia, 1990. 


\section{4) Theory and History of Skaz}

Andruszko, Czeslaw, Skaz v povesti i romane 20-kh godov: L. Leonov, A. Neverov, I. Babel', Poznan: Wydawnictwo Naukowe Universytetu im. Adama Mickiewicza, 1987.

Ansberg, Aleksej, 'Frame Story and First Person Story in N. S. Leskov', Scando Slavica, 3 (1957), 49-73.

Baer, Joachim, 'The Physiological Sketch', in J. Baer and N. Ingham (eds), Mnemozina: Studiia Literaria in Honorem Vsevolod Setchkarev, Munich: Wilhelm Fink, 1970, 1-12.

Bakhtin, Mikhail, Problemy tvorchestva Dostoevskogo, Leningrad, Priboi, 1929; repr. Moscow, Alkonost, 1994; tr.: Problems of Dostoevsky's Poetics, ed. and tr. Caryl Emerson with an introduction by Wayne C. Booth, Minneapolis: University of Minnesota Press, 1984. [This is a translation of the 1963 revised edition of Bakhtin's 1929 book. The chapter from the 1929 edition relevant to this thesis has been separately translated: 'Discourse Typology in Prose', tr. Richard Balthazar and Irwin Titunik, in L. Matejka and K. Pomorska (eds), Readings in Russian Poetics: Formalist and Structuralist Views, Cambridge MA: MIT Press, 1971, 176-98].

Carden, Patricia, 'Ornamentalism and Modernism', in George Gibian and H. W. Tjalsma (eds), Russian Modernism: Culture and the Avant-garde 1900-1930, Ithaca NY and London, Cornell University Press, 1976, 49-64.

Cavendish, Philip, 'Evgenii Zamiatin and the Literary Stylisation of Rus", unpublished doctoral thesis, University of London, 1997.

Chvany, Catherine, 'Stylistic Uses of Affective Suffixes in Leskov', in J. Baer and N. Ingham (eds), Mnemozina: Studiia Literaria in Honorem Vsevolod Setchkarev, Munich: Wilhelm Fink, 1970, 64-77. 
Chudakov, Aleksandr, Chekhov's Poetics, tr. Edwina Jannie Cruise and Donald Dragt, Ann Arbor MI: Ardis, 1983.

de Labriolle, François, 'Le Levša de Leskov: skaz rasskaz ou skazka', Revue des études slaves, 58/3 (1986), 373-91.

Deriagin, V., 'Predislovie', in Vladimir Dal', Polnoe sobranie sochinenii v vos'mi tomakh, ed. V. Ia Deriagin and Z. S. Deriagina, Moscow: Stolitsa, 1995, I, vi-xv.

Doložel, Lubomír, 'The Typology of the Narrator: Point of View in Fiction', To Honor Roman Jakobson. Essays on the Occasion of His Seventieth Birthday: 11th October 1966, The Hague: Mouton, 1967, I, 541-52.

Drožda, Miroslav, 'Khudozhestvenno-kommunikativnaia maska skaza', Zbornik za slavistiku, 18 (1980), 29-48.

Eikhenbaum, Boris, 'Illiuziia skaza' [1918], in Jurij Striedter (ed.), Texte der Russischen Formalisten, Munich: Wilhelm Fink, 1969, I, 160-66; tr. Martin P. Rice, 'The Illusion of Skaz', Russian Literature Triquarterly, 12 (1975), 233-36. 'Kak sdelana "Shinel”" Gogolia' [1919], in Jurij Striedter (ed.), Texte der Russischen Formalisten, Munich: Wilhelm Fink, 1969, I, 122-58; tr. Robert Maguire, 'How Gogol's “Overcoat” is Made', in Gogol From the Twentieth Century: Eleven Essays, ed. Robert Maguire, Englewood Cliffs NJ: Prentice Hall, $1967,267-92$. 'Leskov i sovremennaia proza' [1925], in Jurij Striedter (ed.), Texte der Russischen Formalisten, Munich: Wilhelm Fink, 1969, I, 208-42.

Elsworth, John, Andrey Bely: A Critical Study of the Novels, Cambridge: Cambridge University Press, 1983.

English, Christopher, “"Schalk Lourens and Ivan Flyagin”: A Study of the Skaz Mode of Narration with Reference to the Stories of Leskov and Bosman', in Henrietta Mondry (ed.), The Waking Sphinx: South African Essays on Russian Culture, Johannesburg: University of the Witwatersrand, 1989, 145-60. 
Erlich, Victor, 'Some Uses of Monologue in Prose Fiction: Narrative Manner and Worldview', in Paul Böckmann (ed.), Stil- und Formprobleme in der Literatur: Vorträge des VII Kongresses der Internationalen Vereingung für moderne Sprachen und Literaturen in Heidelberg, Heidelberg: Carl Winter; Universitätsverlag, 1959, 371-78. , 'Notes on the Uses of Monologue in Artistic Prose', International Journal of Slavic Linguistics and Poetics, 1-2 (1959), 223-31. , Modernism and Revolution: Russian Literature in Transition, Cambridge

MA: Harvard University Press, 1994.

Fed', Nikolai, Zelenaia vetv' literatury: russkii literaturnyi skaz, Moscow:

Sovremennik, 1981. , Paradoks o polozhitel'nom geroe, Moscow: Sovremennik, 1986. , 'Russkii literaturnyi skaz', in Zhanry $v$ meniaiushchemsia mire, Moscow: Sovetskaia Rossiia, 1989, 238-524.

Gebel', Valentina, N. S. Leskov: v tvorcheskoi laboratorii, Moscow: Sovetskii pisatel', 1945.

Gei, N. K. et al. (eds), Teoriia literaturnykh stilei: mnogoobrazie stilei sovetskoi literatury. Voprosy tipologii, Moscow: Nauka, 1978.

Gifford, April E., 'The Narrative Technique of Skaz', unpublished doctoral thesis, Stanford University, 1993.

Gofman, V., 'Fol klornyi skaz Dalia' [1926], in Boris Eikhenbaum and Iurii Tynianov, (eds), Russkaia proza; repr. The Hague: Mouton, 1963, 232-57. Grossman, Leonid, Nikolai Leskov, Moscow: Ogiz, 1945. , 'Parodiia kak zhanr literaturnoi kritiki', in B.Begak, N. Kravtsov, A.Morozov, Russkaia literaturnaia parodiia, Moscow: Gosizdat, 1930; repr. Ann Arbor MI: Ardis, 1980, 39-48.

Hamon, Philippe, 'On the Major Features of Realist Discourse', in Lilian R. Furst (ed.), Realism, London: Longman, 1992, 166-85. 
Heldt, Barbara, 'Female Skaz in Sasha Sokolov's Between Dog and Wolf', Canadian American Slavic Studies, 21/3-4 (Fall-Winter 1987), 279-85.

Hetényi, Zsuzsa, ““Chto moi glaza sobstvennoruchno videli...”: osobennosti skazovykh tekstov v, "Konarmii" I. Babelia', Studia Slavica Academiae Scientarium Hungaricae, 38/1-2 (1993), 95-101.

Hodel, Robert, 'Konstrukstiia skaza', Zbornik Matitse srbske za slavistiku, 38 (1990), $59-74$.

, Betrachtungen zum Skaz bei N. S. Leskov und Dragoslav Mihailović, Bern: Peter Lang, 1994.

Hodgson, Peter, 'More on the Matter of Skaz: The Formalist Model', in V. Markov and D. S. Worth (eds), From Los Angeles to Kiev, Columbus OH: Slavica, 1983, 119-54.

Hohne, Karen Ann, 'Skaz and Babel's Konarmija', unpublished doctoral thesis, Indiana University, 1986.

'Dialects of Power: The Two Faced Narrative', in Cythia Goldin Bernstein (ed.), The Text and Beyond: Essays in Literary Linguistics, Tuscaloosa: University of Alabama Press, 1994, 227-38.

Kargashin, I. A., 'Skaz kak sposob rechevoi organizatsii proizvedeniia', in Tvorchestvo Mandel'shtama i voprosy istoricheskoi poetiki (Mezhvuzovskii sbornik nauchnykh trudov), Kemerovo: Kemerovskii gosudarstvennyi universitet, 1990, $114-21$.

Keys, Roger, 'The Unwelcome Tradition: Bely, Gogol, and Metafictional Narration', in Jane Grayson and Faith Wigzell (eds), Nikolay Gogol: Text and Context, London: Macmillan, 1989, 92-108.

Kodrianskaia, Natal`ia, Aleksei Remizov, Paris: Natalie Codray, 1959.

Kozhevnikova, Kveta, 'Sub"ektivizatsiia i ee otnoshenie k stiliu sovremennoi epicheskoi prozy', Československá rusistika, $13 / 4$ (1968), 236-42. 
Kozhevnikova, Natal'ia, 'O tipakh povestvovaniia v sovetskoi proze', in V. D. Levin (ed.), Voprosy iazyka sovremennoi russkoi literatury, Moscow: Nauka, 1971, $97-$ 163.

, 'Iz nabliudenii nad neklassicheskoi (ornamental'noi) prozoi', Izvestiia Akademii Nauk: seriia literatury i iazyka, 35/1 (1976), 55-66. , Tipy povestvovaniia v russkoi literature XIX-XX vekov, Moscow: Institut russkogo iazyka Rossiiskoi Akademii Nauk, 1994.

Levin, V. D. (ed.), Voprosy iazyka sovremennoi russkoi literatury, Moscow: Nauka, 1971.

, 'Literaturnyi iazyk i khudozhestvennoe povestvovanie', in V. D. Levin (ed.), Voprosy iazyka sovremennoi russkoi literatury, Moscow: Nauka, 1971, 9-96. , “"Neklassicheskie” tipy povestvovaniia nachala XX veka v istorii russkogo literaturnogo iazyka', Slavica Hierosolymitana, 5-6 (1981), 245-75.

Lodge, David, After Bakhtin: Essays on Fiction and Criticism, London: Routledge, 1990. ,The Art of Fiction, London: Secker and Warburg, 1992.

McLean, Hugh, 'On the Style of a Leskovian Skaz', Harvard Slavic Studies, 2 (1954), 297-322.

, Nikolai Leskov: The Man and his Art, Cambridge MA, Harvard University Press, 1977.

Magarshack, David, Gogol: A Life, London: Faber and Faber, 1957.

Maguire, Robert, Exploring Gogol, Stanford CA: Stanford University Press, 1994.

Marcadé, Jean-Claude, 'Des Barbarismes étymologiques dans la prose de N. S. Leskov ou la réétymologisation créatrice comme figure du "conte oral" (skaz)', Revue des études slaves, 49 (1973), 256-78.

Medvedev, Pavel/ Bakhtin, Mikhail, Formal'nyi metod v literaturovedenii, New York: Serebrianyi vek, 1982; tr.: Medvedev, Pavel/ Bakhtin, Mikhail, The Formal 
Method in Literary Scholarship: A Critical Introduction to Sociological Poetics, tr.

Albert J. Wehrle, Cambridge MA, Harvard University Press, 1985.

Mel'nikov, P. I., 'Vladimir Ivanovich Dal': kritiko-biograficheskii ocherk', in Vladimir Dal', Polnoe sobranie sochinenii v vos'mi tomakh, Moscow: Stolitsa, 1995, I, xvi-lxxxii.

Meyer, Priscilla, 'Skaz in the Work of Juz Aleškovskij', Slavic and East European Journal, 28/1 (Spring 1984), 455-461.

Mikhniukevich, V. A., 'Zhanrovaia priroda literaturnogo skaza', in Faina Z. Kanunova et al. (eds), Problemy literaturnykh zhanrov: materialy tret'ei mezhvuzovskoi konferentsii 6 fevralia - 9 fevralia 1979 goda, Tomsk: Izd. Tomskogo universiteta, 1979, 160-62.

Mushchenko, E. G., V. P. Skobelev, L. E. Kroichik, Poetika Skaza, Voronezh: Izd. Voronezhskogo gosudarstvennogo universiteta, 1978.

Peace, Richard, The Enigma of Gogol': An Examination of the Writings of $N$. $V$. Gogol' and Their Place in the Russian Literary Tradition, Cambridge: Cambridge University Press, 1981.

Pechey, Graham, 'Bakhtin, Marxism and Post-Structuralism', in F. Barker et al. (eds), Literature, Politics and Theory: Papers from the Essex Conference 1976-84, London: Methuen, 1986.

Rice, Martin P., 'On Skaz', Russian Literature Triquarterly, 12 (1975), 409-24.

Rosenthal, Charlotte, 'Primitivism in Remizov's Early Short Works (1900-1903)', in Greta N. Slobin (ed.), Aleksej Remizov: Approaches to a Protean Writer, Columbus OH: Slavica, 1987, 195-205.

Rybakov, N. I., 'K probleme skaza v khudozhestvennoi literature', Uchenye zapiski Moskovskogo pedagogicheskogo instituta im. V. I. Lenina, 485 (1972), 80-97.

Sadetskii, Aida, 'Les Problèmes de la métaphorisation d'un terme. La présupposition: son rôle dans la compréhension adéquate de la terminologie de la science théoricolittéraire russe', Langues et linguistique, 9 (1983), 1-43. 
Samyshkina, A. V., 'K probleme gogolevskogo fol klorizma (dva tipa skaza i literaturnaia polemika v "Vecherakh na khutore bliz Dikan 'ki")', Russkaia literatura, 22/3 (1979), 61-80.

Shane, Alex M., The Life and Works of Evgenij Zamjatin, Berkeley: University of California Press, 1968.

_, 'Remizov's Prud: From Symbolism to Neo-Realism', California Slavic Studies, 6 (1971), 71-82.

Slobin, Greta N., Remizov's Fictions 1900-1921, DeKalb: Northern Illinois University Press, 1991. (ed.), Aleksej Remizov: Approaches to a Protean Writer, Colombus $\mathrm{OH}$ : Slavica, 1987,

Szilárd, Léna, ‘Ornamental’nost'/ Ornamentalizm', Russian Literature, 19 (1986), 6578. , 'Skaz as a Form of Narration in Russian and Czech Literature', in Jean Bessière (ed.), Fiction, texte, narratologie, genre, New York: Peter Lang, 1989, $181-90$.

Thompson, Ewa, Russian Formalism and Anglo-American Criticism: A Comparative Study, The Hague: Mouton, 1971.

Thresher, Klawa Nepscha, 'Narration in Selected Short Works by Nikolaj Gogol': An Investigation into Multiple Narrative Modes and the Presence of Skaz', unpublished doctoral thesis, University of Wisconsin, 1992.

Titunik, Irwin, 'The Problem of Skaz in Russian Literature', unpublished doctoral thesis, Berkeley: University of California, 1963.

, 'Das Problem des Skaz: Kritik und Theorie', in Wolfgang Haubrichs (ed.), Zeitshcrift für Literaturwissenschaft und Linguistik: Beiheft 6; Erzählforschung 2; Theorien, Modelle und Methoden der Narrativik, Göttingen: Vandenhoeck and Ruprecht, 1977, 114-40. 
Tomashevskii, Boris, Stilistika i stikhoslozhnenie: kurs lektsii, Leningrad:

Gosudarstvennoe uchebno-pedagogicheskoe izd. ministerstva prosveshcheniia RSFSR, 1959.

Tupichekova, M., 'Skaz v proze V. Shukshina i V. Belova', Vestnik Moskovskogo universiteta: seriia 9; filologiia, 2 (1987), 19-24.

Tynianov, Iurii, 'Literaturnoe segodnia' [1924], repr. in Iurii Tynianov, Poetika. Istoriia literatury. Kino, Moscow: Nauka, 1977, 150-66.

Vinogradov, Viktor, 'Problema skaza v stilistike' [1925], repr. in Jurij Striedter (ed.), Texte der Russischen Formalisten, Munich: Wilhelm Fink, 1969, I, 168-206; tr. Martin P. Rice, 'The Problem of Skaz in Stylistics', Russian Literature Triquarterly, 12 (1975), 237-50. , 'Problema obraza avtora v khudozhestvennoi literature', in Viktor Vinogradov, O teorii khudozhestvennoi prozy, Moscow: Vysshaia shkola, 1971, 105-211.

Waszink, P. M., "Such Things Happen in the World": Deixis in Three Short Stories by N. V. Gogol', Amsterdam: Rodopi, 1988.

Zakharov, Vladimir Nikolaevich, Sistema zhanrov Dostoevskogo: tipologiia i poetika, Leningrad: Izd. Leningradskogo universiteta, 1985.

Zeldin, Jesse, Nikolai Gogol's Quest for Beauty: An Exploration into his Works, Lawrence: The Regent's Press of Kansas, 1978.

\section{5) Other Literary Theory and History}

Andrew, Joe, Writers and Society During the Rise of Russian Realism, London: Macmillan, 1980.

Aristotle, Poetics, tr. with an introduction by Malcom Heath, Harmondsworth: Penguin, 1996.

Azbelev, S. I., 'Sovremennye ustnye rasskazy', Russkii fol 'klor, 9 (1964), 132-77. 
Bal, Mieke, Narratology: Introduction to the Theory of Narrative, tr. Christine van Boheemen, Toronto: University of Toronto Press, 1985.

Bakhtin, Mikhail, Rabelais and His World, tr. Helene Iswolsky, Cambridge MA: MIT Press, 1968

Banfield, Ann, Unspeakable Sentences: Narration and Representation in the Language of Fiction, Boston: Routledge and Kegan Paul, 1982.

Bann, Stephen and John Bowlt (eds), Russian Formalism, Edinburgh: Scottish Academic Press, 1973.

Barthes, Roland, Image, Music, Text, tr, Stephen Heath, London: Fontana, 1977.

Behler, Ernst, Irony and the Discourse of Modernity, Seattle: University of Washington Press, 1990.

Benjamin, Walter, 'The Storyteller: Reflections on the Work of Nikolai Leskov', in Walter Benjamin, Illuminations, tr. Harry Zohn, ed. with an introduction by Hannah Arendt, London: Fontana, 1992, 83-107.

Berman, Marshall, All That is Solid Melts into Air: The Experience of Modernity, London: Verso, 1983.

Blagoi, D. (ed.), Istorii russkoi literatury v trekh tomakh, Moscow and Leningrad: Izd. Akademii Nauk SSSR, 1963.

Bocharov, A., Literatura i vremia: iz tvorcheskogo opyta prozy 60-kh-80-kh godov, Moscow: Khudozhestvennaia literatura, 1988.

Bonetskaia, N. K., 'Problemy metodologii analiza obraza avtora', in Iu. B. Borev (ed.), Metodologii analiza literaturnogo proizvedeniia, Moscow: Nauka, 1988, 6085.

Booth, Wayne C., A Rhetoric of Fiction, Chicago IL: Chicago University Press, 1961. , A Rhetoric of Irony, Chicago IL: University of Chicago Press, 1974.

Bradbury, Malcom and James McFarlane (eds), Modernism 1890-1930, 2nd edn, rev., Harmondsworth: Penguin, 1991. 
Chernyshevskii, Nikolai, Polnoe sobranie sochinenii v piatnadtsati tomakh, ed. V. Ia. Kirpotin et al., Moscow: Gosudarstvennoe izd. khudozhestvennoi literatury, 193953.

Cioffi, Frank, 'Intention and Interpretation', in David Newton de Molina (ed.), On Literary Intention: Critical Essays, Edinburgh: Edinburgh University Press, 1976, 55- 73.

Coblentz, Stanley A., The Literary Revolution, New York: Frank-Maurice, 1927.

Dane, Joseph A., The Critical Mythology of Irony, Athens: University of Georgia Press, 1991.

de Molina, David Newton (ed.), On Literary Intention, Edinburgh: Edinburgh University Press, 1976.

Efimov, Aleksandr, Stilistika khudozhestvennoi rechi, Moscow: Izd. Moskovskogo universiteta, 1957.

Erlich, Victor, Russian Formalism: History, Doctrine, The Hague: Mouton, 1955.

Fludernik, Monika, The Fictions of Language and the Languages of Fiction, London: Routledge, 1993.

Foley, Barbara, Telling the Truth: The Theory and Practice of Documentary Fiction, Ithaca NY: Cornell University Press, 1986.

Freeborn, Richard, The Rise of the Russian Novel: Studies in the Russian Novel from Eugene Onegin to War and Peace, Cambridge: Cambridge University Press, 1973.

Furst, Lilian R., The Contours of European Romanticism, London: Macmillan, 1975.

Gaitet, Pascale, Political Stylistics: Popular Language as Literary Artefact, London: Routledge, 1992.

Garrard, John (ed.), The Russian Novel from Pushkin to Pasternak, New Haven CT: Yale University Press, 1983.

Gei, N. (ed.), Teoriia literaturnykh stilei: tipologiia stilevogo razvitiia IXX veka, Moscow: Nauka, 1977. 
Gofman, Viktor, Iazyk literatury (ocherki i etiudy), Leningrad: Gosudarstvennoe izd. khudozhestvennoi literatury, 1936.

Głowinski, Michal, 'On the First-Person Novel', tr. Rochelle Stone, New Literary History, 9 (1977), 103-14.

Griffin, Dustin, Satire: A Critical Reintroduction, Lexington: University of Kentucky Press, 1994.

Gukovskii, G. A., Realizm Gogolia, Moscow and Leningrad: Gosudarstvennoe izd. khudozhestvennoi literatury, 1959.

Gvozdev, A. N., Sovremennyi russkii literaturnyi iazyk: posobie dlia pedagogicheskikh institutov, 2 vols, Moscow: Gosudarstvennoe uchebnopedagogicheskoe izd. ministerstva prosveshcheniia RFSFR, 1963.

Hutcheon, Linda, A Theory of Parody: The Teachings of Twentieth-Century Art Forms, New York: Methuen, 1985. , Irony's Edge: The Theory and Politics of Irony, London: Routledge, 1994.

Hutchings, Stephen C., Russian Modernism: The Transfiguration of the Everyday, Cambridge: Cambridge University Press, 1997.

Iseminger, Gary (ed.), Intention and Interpretation, Philadelphia PA: Temple University Press, 1992.

Jones, Malcom V. and Robin Miller (eds), The Classic Russian Novel, Cambridge: Cambridge University Press, 1998.

Josipovici, Gabriel, 'The Lessons of Modernism', in Gabriel Josipovici, The Lessons of Modernism and Other Essays, 2nd edn, London: Macmillan, 1997, 109-23.

Kierkegaard, Søren, The Concept of Irony with Continual Reference to Socrates, tr. H.V. and E. H. Hong, Princeton NJ: Princeton University Press, 1989.

Kozhinov, V. V., 'Golos avtora i golosa personazhei’, in N. K. Gei et al. (eds), Problemy khudozhestvennoi formy sotsialisticheskogo realizma ( $v$ dvukh tomakh), I: Aspekty izucheniia: khudozhestvennaia forma i deistvitel'nost’’, Moscow: Nauka, $1971,195-235$. 
Lomunov, K. N. et al. (eds), Razvitie realizma v russkoi literature, 3 vols, Moscow: Nauka, 1972.

Lord, Albert Bates, 'The Transitional Text', in Albert Bates Lord and Mary Louise Lord (ed.), The Singer Resumes the Tale, Ithaca NY: Cornell University Press, 1995, 212-37.

Loseff, Lev, On the Beneficence of Censorship: Aesopian Language in Modern Russian Literature, Munich: Otto Sagner, 1984.

Lyas, Colin, Aesthetics, London: University College London Press, 1997. , 'Wittgensteinian Intentions', in Gary Iseminger (ed.), Intention and Interpretation, Philadelphia PA: Temple University Press, 1992, 132-51.

Miller, Frank J., Folklore for Stalin: Russian Folklore and Pseudo Folklore of the Stalin Era, New York: M.E. Sharpe, 1990.

Mints, Z. G., 'Russkii simvolizm i revoliutsiia 1905-1907 godov', Uchenye zapiski Tartuskogo gosudarstvennogo universiteta, 813 (1988), 3-21.

Mirsky, D. S., A History of Russian Literature, ed. and abridged by Francis J. Whitfield, London: Routledge and Kegan Paul, 1949.

Morson, Gary Saul and Caryl Emerson, Mikhail Bakhtin: Creation of a Prosaics, Stanford CA: Stanford University Press, 1990.

Moser, Charles A. (ed.), The Cambridge History of Russian Literature, rev. edn, Cambridge: Cambridge University Press, 1992.

Muecke, D. C., Irony and the Ironic, 2nd edn, rev., London: Methuen, 1982.

Nash, Christopher, World - Games: The Tradition of Anti-Realist Revolt, London: Methuen, 1987.

Nilsson, Nils Åke, 'Futurism, Primitivism and the Russian Avant-Garde', Russian Literature, 8 (1980), 469-82.

Oinas, Felix J., 'Folkloric Activities and Scholarship in Russia', in Felix J. Oinas, Essays on Russian Folklore and Mythology, Columbus OH: Slavica, 1985. 
Ong, Walter J., Interfaces of the Word: Studies in the Evolution of Consciousness and Culture, Ithaca NY: Cornell University Press, 1977. , Orality and Literacy: The Technologizing of the Word, London: Methuen, 1982; repr. London: Routledge, 1990.

Paperno, Irina and Joan Delaney Grossman (eds), Creating Life: The Aesthetic Utopia of Russian Modernism, Stanford CA: Stanford University Press, 1994.

Paulson, Ronald, The Fictions of Satire, Baltimore MD: John Hopkins Press, 1967.

Pearce, Lynne, Reading Dialogics, London: Edward Arnold, 1994.

Poliakov, M., Voprosy poetiki i khudozhestvennoi semantiki, Moscow: Sovetskii pisatel', 1986.

Pollard, Arthur, Satire, London: Methuen, 1970.

Pospelov, G., Epokha rastsveta kriticheskogo realizma: iz kurs lektsii po istorii russkoi literatury XIX veka, Moscow: Izd. Moskovskogo universiteta, 1958.

Propp, Vladimir, Problemy komizma i smekha, 2nd edn, St Petersburg: Aleteiia, 1997.

Ricoeur, Paul, Interpretation Theory: Discourse and the Surplus of Meaning, Fort Worth TX: The Texas Christian University Press, 1976.

Rose, Margaret A., Parody: Ancient, Modern and Post-Modern, Cambridge: Cambridge University Press, 1993.

Ryan-Hayes, Karen L., Contemporary Russian Satire: A Genre Study, Cambridge: Cambridge University Press, 1995.

Sangsue, Daniel, La Parodie, Paris: Hachette, 1984.

Schopenhauer, Arthur, Die Welt als Wille und Vorstellung, Stuttgart: Cotta-Insel, 1960.

Shepherd, David, Beyond Metafiction. Self-Consciousness in Soviet Literature, Oxford: Clarendon Press, 1992.

Sokolov, Iu. M., Russkii fol'klor, Moscow: Uchpedgiz, 1938.

Sperber, Dan and Wilson, Deidre, 'Irony and the Use-Mention Distinction', in P. Cole (ed.), Syntax and Semantics 9: Pragmatics, New York: Academic Press, 1981, 
295-318; repr. in Steven Davis (ed.) Pragmatics: A Reader, Oxford: Oxford University Press, 1991, 550-63.

Stern, J. P., On Realism, London: Routledge and Kegan Paul, 1973.

Stevenson, Randall, Modernism: An Introduction, New York: Harvester Wheatsheaf, 1992.

Terras, Victor, Belinskij and Russian Literary Criticism: The Heritage of Organic Aesthetics, Madison: University of Wisconsin Press, 1974.

Thomson, J. A. K., Irony: An Historical Introduction, London: Allen and Unwin, 1926.

Tunimanov, V. A., 'Rasskazchik v "Besakh” Dostoevskogo', in Issledovaniia po poetike i stilistike, Leningrad: Nauka, 1974.

Tynianov, Iurii, Arkhaisty i novatory, Leningrad: Priboi, 1929; repr. Munich: Wilhelm Fink, 1967.

Vinogradov, Viktor, Evoliutsiia russkogo naturalizm: Gogol’i Dostoevskii, Leningrad: Academia, 1929.

Vinogradov, Viktor, Ocherki po istorii russkogo literaturnogo iazyka XVII-XIX vekov, Leyden: E. I. Brill, 1949.

Volkov, Ivan, Teoriia literatury: uchebnoe posobie dlia studentov i prepodovatelei, Moscow: Prosveshchenie; Vlados, 1995.

Vroon, Ronald, 'The Garden in Russian Modernism', Revue des études slaves, 69/1-2 (1997), 135-49.

Wimsatt, W.K. and Beardsley, M.C., 'The Intentional Fallacy', in The Verbal Icon: Studies in the Meaning of Poetry, Lexington: University of Kentucky Press, 1954, 3-30; repr. in David Newton de Molina (ed.), On Literary Intention, Edinburgh: Edinburgh University Press, 1976, 1-13. 


\section{6) Reference Works and Other Works Consulted}

Bol'shaia sovetskaia entsiklopediia, Moscow: Ogiz (Sovetskaia entsiklopediia), 192631.

Bol'shaia sovetskaia entsiklopediia, 2nd edn, Moscow: Ogiz (Sovetskaia entsiklopediia), 1949-58.

Bol'shaia sovetskaia entsiklopediia, 3rd edn, Moscow: Sovetskaia entsiklopediia, 1970-8.

Calvino, Italo, Italian Folktales, tr. George Martin, New York: Harcourt Brace Jovanovich, 1980; repr. Harmondsworth: Penguin, 1982.

Chekhov, Anton, Polnoe sobranie sochinenii i pisem v tridtsati tomakh; pis'ma v dvenadtsati tomakh, ed. N. F. Bel'chikov et al., Moscow: Nauka, 1974-83.

Dal', Vladimir, Tolkovyi slovar' zhivogo velikorusskogo iazyka, St. Petersburg: Vol’f, 1880-82; repr. Moscow: Russkii iazyk, 1981-82.

Dostoevskii, Fedor, Polnoe sobranie sochinenii v tridtsati tomakh, ed. V. G. Bazanov et al., Leningrad: Nauka, 1972-88.

Engels, Frederick, Ludwig Feuerbach and the End of Classical German Philosophy, Peking: Foreign Languages Press, 1976.

Kasack, Wolfgang, Lexikon der Russischen Literatur des 20-Jahrhunderts, Munich: Otto Sagner, 1994.

Kierkegaard, Søren, Papers and Journals: A Selection, tr. with introduction and notes by Alastair Hannay, Harmondsworth: Penguin , 1996, p. 105.

Kratkaia literaturnaia entsiklopediia, 9 vols, Moscow: Sovetskaia entsiklopediia, 1962-78.

Literaturnaia entsiklopedia, 11 vols, I-IX and XI: Moscow: Izd. Kommunisticheskoi Akademii, 1930-39; X, Munich: Otto Sagner, 1991.

Lyons, John, Semantics, 2 vols, Cambridge: Cambridge University Press, 1977. , Language, Meaning and Context, London: Fontana, 1981. 
Milton, John, The Poems of John Milton, ed. John Carey and Alastair Fowler, London: Longman, 1968.

Nikolaev, M. A. (ed.), Russkie pisateli: biobibliograficheskii slovar', Moscow: Prosveshchenie, 1990.

Prince, Gerald, A Dictionary of Narratology, Lincoln: University of Nebraska Press; paperback repr. Aldershot: Scholar Press, 1991.

Pushkin, Aleksandr, Polnoe sobranie sochinenii v desiati tomakh, Moscow: Akademiia Nauk, 1938-50.

Russell, Bertrand, Power: A New Social Analysis, London: Allen and Unwin, 1963.

Terras, Victor, A Handbook of Russian Literature, New Haven CT: Yale University Press, 1985.

Timofeev, L. I. and Ruraev, S. V., Slovar' literaturovedcheskikh terminov, Moscow: Prosveshchenie, 1974.

Turgenev, Ivan, Polnoe sobranie sochinenii i pisem vdvadtsati vos'mi tomakh, ed. M. P. Alekseev et al., Moscow and Leningrad: Izd. Akademii Nauk SSSR, 1960-68.

Ushakov, D. N. (ed.), Tolkovyi slovar' russkogo iazyka, 4 vols, Moscow: Ogiz, 1940. 